\title{
REMOVAL OF ENGINEERED NANOPARTICLES IN DRINKING WATER TREATMENT Processes
}

ROBERTO FLORIS 



\section{REMOVAL OF ENGINEERED}

\section{NANOPARTICLES IN DRINKING \\ WATER TREATMENT PROCESSES}

ROBERTO FLORIS 
This research is sponsored by the Joint Research Programme of KWR Watercycle Research Institute for the Dutch Drinking Water Companies and is supported by NanoNextNL, a micro and nanotechnology consortium of the Government of the Netherlands and 130 partners.

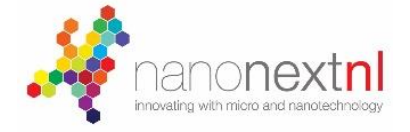

MESA+

INSTITUTE FOR NANOTECHNOLOGY

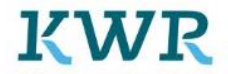

Watercycle Research Institute

PENTAIR X-FLOW
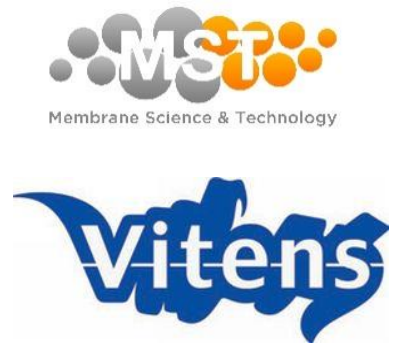

Cover: designed by Roberto Floris, SEM photo by Herman Teunis

Removal of engineered nanoparticles in drinking water treatment processes

ISBN: 978-90-365-4321-7

URL: https://doi.org/10.3990/1.9789036543217

Printed by Gilderprint Drukkerijen

(C) Roberto Floris, Amsterdam, Netherlands 


\title{
REMOVAL OF ENGINEERED
}

\section{NANOPARTICLES IN DRINKING}

\section{WATER TREATMENT PROCESSES}

\section{DISSERTATION}

\author{
to obtain \\ the degree of doctor at the University of Twente, \\ on the authority of the Rector Magnificus, Prof. dr. T.T.M. Palstra \\ on account of the decision of the Graduation Committee, \\ to be publicly defended \\ on Friday the $3^{\text {rd }}$ of March 2017 at 16.45
}

by

Roberto Floris

born on July $8^{\text {th }}, 1979$

in Iglesias, Sardigna, Italy 
This thesis has been approved by:

Prof. dr. ir. D. C. Nijmeijer

Dr. ir. E. R. Cornelissen

\section{Promotion Committee}

Chairman:

Prof. dr. ir. J.W.M. Hilgenkamp

Universiteit Twente, TNW

Promotor:

Prof. dr. ir. D. C. Nijmeijer

Technische Universiteit Eindhoven

Co-promotor:

Dr. ir. E. R. Cornelissen

KWR Watercycle Research Institute Members:

Prof. dr. F. G. Mugele

Universiteit Twente, TNW

Prof. dr. ir. R. G. H. Lammertink

Universiteit Twente, TNW

Prof. dr. ir. L. C. Rietveld

Technische Universiteit Delft

Prof. dr. A. R. D. Verliefde

Universiteit Gent 
to my family 

We passed through earth lightly as water, said Antonio Setzu, as water flowing, springs, from the dip full of the fountain, slides and winds among moss and ferns, down to the roots of the cork oak and almond trees or slips down on the stones, through the mountains and the hills up to the plan, from the streams to the river, slows down towards the swamps and the sea, called by the sun to become vapour and wind dominated cloud and blessed rain. Apart from the madness of killing each other for irrelevant reasons, we were happy. The plants and swamps were fertile, mountains rich of pasture and springs. The food was not lacking even in the years of famine. We did a blood-colored wine, sweet on the palate, and a bearer of happy dreams. On the seventh day of the folding oaks wind month we used met all the nations around the sacred spring, and for seven days and seven nights we ate, drank, we sang and danced in honor of Is. Singing, playing, dancing, grow, harvest, milking, carving, melting, kill, die, singing, playing, dancing was our life. We were happy, apart from the madness of killing each other for insignificant reasons.

Passavamo sulla terra leggeri come acqua, disse Antonio Setzu, come acqua che scorre, salta, giù dalla conca piena della fonte, scivola e serpeggia fra muschi e felci, fino alle radici delle sughere e dei mandorli o scende scivolando sulle pietre, per i monti e i colli

fino al piano, dai torrenti al fiume, a farsi lenta verso le paludi e il mare, chiamata in vapore dal sole a diventare nube dominata dai venti e pioggia benedetta. A parte la follia di ucciderci l'un l'altro per motivi irrilevanti, eravamo felici. Le piante e le paludi erano fertili, i monti ricchi di pascolo e fonti. Il cibo non mancava neppure negli anni di carestia.

Facevamo un vino colore del sangue, dolce al palato e portatore di sogni allegri. Nel settimo giorno del mese del vento che piega le querce incontravamo tutte le genti attorno alla fonte sacra e per sette giorni e sette notti mangiavamo, bevevamo, cantavamo e danzavamo in onore di Is. Cantare, suonare, danzare, coltivare, raccogliere, mungere, intagliare, fondere, uccidere, morire, cantare, suonare, danzare era la nostra vita. Eravamo felici, a parte la follia di ucciderci l'un l'altro per motivi irrilevanti.

Passavamo sulla terra leggeri

Sergio Atzeni 



\section{SUMMARY}

In the last decades, nanotechnology has brought a large number of engineered nanomaterials and nanoparticles to applications in multiple daily products and in almost every sector of society. The many advantages that this relatively new science has brought to our daily life are evident, but still little is known on the potential environmental and human risk posed by nanotechnology applications. Particularly, the potential release into aquatic environment of engineered nanomaterials and nanoparticles raises concerns on the security of resources used for drinking water production. It can also create significant challenges to water treatment facilities in terms of operational optimization and proper process control.

The research presented in this thesis investigates the removal and removal mechanisms of engineered nanomaterials and nanoparticles in simulated drinking water treatment plants. It focuses on how these new potential pollutants affect process performances and which treatments are best to follow for their removal.

Chapter 2 investigates the role of membrane pore size on the removal and removal mechanism of $\mathrm{nC}_{60}$ fullerene nanoparticles from ultrapure water suspensions by microfiltration and ultrafiltration. Under typical full-scale conditions used in the water industry, i.e. dead-end filtration under constant flux and including multiple backwash cycles, almost complete $\mathrm{nC}_{60}$ removal is obtained by membranes with an average pore size smaller and similar/larger than the particle size (distribution), while membranes with an average pore size larger than the particle size (distribution) show very low removal of about $10 \%$. Steric exclusion is the main removal mechanism of $\mathrm{nC}_{60}$ for membranes with an average pore size smaller than the size of $\mathrm{nC}_{60}$, while a combination of intermediate pore blocking and cake formation on top of the membrane surface is the main removal mechanism of $\mathrm{nC}_{60}$ for membranes with an average pore size comparable to the $\mathrm{nC}_{60}$ size.

High removal efficiency of $\mathrm{nC}_{60}$ by microfiltration can be also obtained under relevant environmental conditions (Chapter 3), especially when these nanoparticles are dispersed in (pre-treated) natural surface water with different natural organic matter compositions and concentrations of divalent cations. Water surface composition has no effect on the $\mathrm{nC}_{60}$ removal efficiency, which is always higher than $99.9 \%$. Nonetheless the fouling occurring during microfiltration results in a transmembrane pressure increase considerably higher than 
the simple sum of transmembrane pressure increase during filtration of $\mathrm{nC}_{60}$ in ultrapure water and that during filtration of surface water without $\mathrm{nC}_{60}$. This synergistic effect is especially dominant when the negatively charged natural organic matter is present in the water and less dependent on the presence of divalent cations. It is hypothesized that during filtration of surface water containing $\mathrm{nC}_{60}$, the nanoparticles may fill the void spaces between the natural organic matter deposited on the membrane surface, thus leading to a lower cake porosity and therefore a higher filtration resistance.

The removal efficiency results obtained at lab-scale are validated at pilot scale in Chapter 4. The pilot investigations show high removal efficiencies for silver and gold although the nanoparticle size is smaller than the membrane pore size. This is in agreement with previous findings (Chapters 2 and 3). Visual observations during membrane autopsy suggest that the removal mechanism is still a combination of size exclusion and pore blockage. However, the transmembrane pressure profile during microfiltration of silver and gold is reasonably flat (both on pilot and lab scale), which is different from what was observed for $\mathrm{nC}_{60}$ microfiltration on lab scale. This suggests or (i) different filtration resistances of the cake layer formed on top of the membrane due to the different nature of the nanoparticles or (ii) the formation of a cake layer only, without the occurrence of pore blocking on the membrane surface for silver and gold nanoparticles.

Other than low pressure membrane filtration, this thesis also reports on the removal and removal mechanism of $\mathrm{nC}_{60}$ in coagulation-flocculation-sedimentation processes using ferric chloride as coagulant (Chapter 5). This process is less robust than membrane filtration and $\mathrm{nC}_{60}$ removal efficiencies range from $100 \%$ down to $0 \%$. The removal of $\mathrm{nC}_{60}$ from ultrapure water correlates very well with the hydrolysis behaviour of $\mathrm{Fe}^{3+}$ in water that enhances the removal performance by charge neutralization and destabilization at acidic conditions. At basic conditions removal decreases drastically as the concentration of cationic hydrolysis products of $\mathrm{Fe}^{3+}$ decreases as well. When $\mathrm{nC}_{60}$ is dispersed in surface water, natural organic matter enhances the removal of $\mathrm{nC}_{60}$ at acidic condition by co-precipitation, and decreases the removal of $\mathrm{nC}_{60}$ at the $\mathrm{pH}$ range $6-8$, due to steric hindrance stabilization. While the presence of divalent cations destabilizes the $\mathrm{nC}_{60}$ thus increasing its removal, in the $\mathrm{pH}$ range $6-8$, the presence of negatively charged natural organic matter still dominates the stabilizing effects and hindering the $\mathrm{nC}_{60}$ removal. 
In Chapter 6 the removal effectiveness of $\mathrm{nC}_{60}$ using activated carbon is investigated. Isothermal sorption experiments show that the adsorption of $\mathrm{nC}_{60}$ increases with increasing specific surface area of the activated carbon particles. Powdered activated carbon can completely remove the nanoparticles from ultrapure water if used at adequate dosage, while the removal of $\mathrm{nC}_{60}$ by granular activated carbon is much less efficient. However, under conditions more representative for water treatment applications (filtration of $\mathrm{nC}_{60}$ dispersion through a granular activated carbon bed column), the retention of $\mathrm{nC}_{60}$ is considerably lower $(\sim 90 \%)$. Therefore, results of isothermal sorption experiments with nanoparticles should be handled with care, as these measurements are based on the thermodynamic equilibrium concept and do not include kinetic and (de)stabilizing effects occurring during filtration.

Finally, in Chapter 7, the conclusions of this work are summarized and directions for further research in this field are suggested. 



\section{SAMENVATTING}

In de laatste decennia heeft nanotechnologie een groot aantal van engineered nanomaterialen en nanodeeltjes van toepassingen gebracht in meerdere dagelijkse producten en in bijna alle sectoren van de samenleving. De vele voordelen die deze relatief nieuwe wetenschap op ons dagelijks leven heeft gebracht zijn duidelijk, maar er is nog steeds weinig bekend over de mogelijke risico's van de toepassingen van nanotechnologie over milieu en mensen. Vooral de mogelijke aanwezigheid van engineered nanomaterialen en nanodeeltjes in aquatisch milieu leidt tot bezorgdheid over de veiligheid van de bronnen gebruikt voor de productie van drinkwater. Het zal ook belangrijke uitdagingen voor waterbehandeling veroorzaken, wat betreft de operationele optimalisatie en goede procesbeheersing.

Dit proefschrift beschrijft onderzoek over verwijdering en verwijdering mechanismen van engineered nanomaterialen en nanodeeltjes in gesimuleerde drinkwater zuiveringsinstallaties. Het richt zich op hoe deze nieuwe potentiële verontreinigingen proces optredens beïnvloeden en welke behandelingen geschikt zijn voor de verwijdering ervan.

Hoofdstuk 2 onderzoekt de rol van membraan poriegrootte over de verwijdering en verwijdering mechanisme van de $\mathrm{nC}_{60}$ fullerene nanodeeltjes van ultrapuur water suspensie door microfiltratie en ultrafiltratie. Onder typische grootschalige omstandigheden gebruikt in de waterindustrie, dwz dead-end filtratie onder constante stroom en met meerdere terugspoel cycli, wordt bijna volledige $\mathrm{nC}_{60}$ verwijdering verkregen door membranen met een gemiddelde poriegrootte kleiner, dergelijk of iets groter dan de deeltjesgrootte (verdeling), terwijl membranen met een gemiddelde poriegrootte duidelijk groter dan de deeltjesgrootte (verdeling) vertonen een zeer geringe verwijdering van ongeveer $10 \%$. Sterische uitsluiting is de belangrijkste $\mathrm{nC}_{60}$ verwijdering mechanisme voor membranen met een gemiddelde poriegrootte kleiner dan de grootte van $\mathrm{nC}_{60}$, terwijl een combinatie van tussen poriën verstopping en koekvorming bovenop het membraanoppervlak de belangrijkste $\mathrm{nC}_{60}$ verwijdering mechanisme is voor membranen met een gemiddelde poriëgrootte vergelijkbaar met de $\mathrm{nC}_{60}$ grootte.

Hoog $\mathrm{nC}_{60}$ verwijderingsefficiëntie door microfiltratie wordt ook verkregen onder relevante milieuomstandigheden (Hoofdstuk 3), vooral wanneer de nanodeeltjes gedispergeerd worden in (voorbehandelde) natuurlijk oppervlaktewater met verschillende natuurlijke 
organische stof samenstellingen en divalente kationen concentraties. Oppervlaktewater samenstelling heeft geen effect op de $\mathrm{nC}_{60}$ verwijderingsefficiëntie, die altijd hoger is dan 99,9\%. Toch leidt de fouling tijdens microfiltratie tot een transmembraandruk toename aanzienlijk hoger dan de som van transmembraandruk toename tijdens filtratie van $\mathrm{nC}_{60}$ in ultrapuur water of tijdens de filtratie van oppervlaktewater zonder $\mathrm{nC}_{60}$. Dit synergistische effect is vooral afhankelijk van de aanwezigheid van negatief geladen natuurlijk organisch materiaal in het water en minder afhankelijk van de divalente kationen. Er wordt verondersteld dat de nanodeeltjes, tijdens de filtratie van oppervlaktewater met $\mathrm{nC}_{60}$, de lege ruimten kunnen vullen tussen de natuurlijk organisch materiaal afgezet op het membraanoppervlak, wat leidt tot een lagere koek porositeit en dus een hogere filtratie weerstand.

De laboratoriumschaal verwijderingsefficiëntie resultaten worden gevalideerd op pilotschaal in Hoofdstuk 4. De pilot onderzoek vertoont een hoge verwijderingsefficiëntie voor zilver en goud, hoewel de nanodeeltjes kleiner is dan het membraan poriegrootte. Dit is in overeenstemming met eerdere bevindingen (Hoofdstukken 2 en 3). Uit visuele waarnemingen tijdens membraan autopsie blijkt dat de verwijdering mechanisme nog steeds een combinatie van grootte uitsluiting en porie verstopping is. Maar het transmembraandruk profiel tijdens microfiltratie van zilver en goud is redelijk vlak (zowel bij piloot- en laboratoriumschaal), wat verschilt van laboratoriumschaal resultaten voor $\mathrm{nC}_{60}$ microfiltratie. Dit suggereert of (i) verschillende filtratie weerstanden van de koek gevormd bovenop het membraan vanwege de verschillende aard van de nanodeeltjes of (ii) de vorming van slechts een koeklaag, zonder het optreden van poriën verstopping op het membraanoppervlak voor zilver en goud nanodeeltjes.

Anders dan lagedruk membraanfiltratie, rapporteert dit proefschrift ook over de verwijdering en verwijdering mechanisme van de $\mathrm{nC}_{60}$ in coagulatie-flocculatie-sedimentatie processen met behulp van ijzer chloride als coagulant (Hoofdstuk 5). Dit proces is minder robuust dan membraanfiltratie en $\mathrm{nC}_{60}$ verwijderingsefficiëntie variëren van $100 \%$ tot $0 \%$. De $\mathrm{nC}_{60}$ verwijdering van ultrapuur water correleert goed met de hydrolyse gedrag van $\mathrm{Fe}^{3+}$ in water, dat de verwijdering prestaties verbetert door laden neutralisatie en destabilisatie bij zure condities. Bij basische condities daalt de verwijdering drastisch als ook de concentratie van kationische hydrolyseproducten van $\mathrm{Fe}^{3+}$ vermindert. Wanneer $\mathrm{nC}_{60}$ in oppervlaktewater 
gedispergeerd wordt, verbetert natuurlijke organische stof de verwijdering van $\mathrm{nC}_{60}$ bij zure condities door co-precipitatie, en vermindert het $\mathrm{nC}_{60}$ verwijderen bij $\mathrm{pH}$ 6-8, vanwege sterische hindering stabilisatie. Terwijl de aanwezigheid van divalente kationen destabiliseert de $\mathrm{nC}_{60}$ dus verbetert de verwijdering, domineert nog in het $\mathrm{pH}$-gebied 6-8 de aanwezigheid van negatief geladen natuurlijk organisch materiaal de stabiliserende effect en belemmert de $\mathrm{nC}_{60}$ verwijdering.

In Hoofdstuk 6 wordt $\mathrm{nC}_{60}$ verwijdering effectiviteit met behulp van actieve kool onderzocht. Uit isotherme sorptie experimenten blijkt dat $\mathrm{de}_{\mathrm{nC}_{60}}$ adsorptie toeneemt met toenemende specifiek oppervlak van de geactiveerde koolstofdeeltjes. Actieve kool in poedervorm kunnen de nanodeeltjes volledig uit ultrapuur water verwijderen bij gebruik in adequate dosering, terwijl de $\mathrm{nC}_{60}$ verwijdering door granulaire actieve kool veel minder efficiënt is. Echter, onder omstandigheden die meer representatief zijn voor waterbehandeling toepassingen (filtratie van $\mathrm{nC}_{60}$ dispersie door middel van een actieve kool bed kolom), is het behoud van de $\mathrm{nC}_{60}$ aanzienlijk lager ( $\left.90 \%\right)$. Derhalve zullen resultaten van isotherme adsorptie experimenten met nanodeeltjes voorzichtig omgegaan worden, omdat deze metingen op het thermodynamische evenwicht concept gebaseerd zijn en kinetische en (de) stabiliserende effecten niet bevatten, die tijdens filtratie optreden.

Tenslotte worden de conclusies van dit werk in Hoofdstuk 7 samengevat en aanbevelingen voor verder onderzoek op dit gebied worden voorgesteld. 



\section{SOMMARIO}

Negli ultimi decenni, lo sviluppo della nanotecnologia ha contribuito ad introdurre un alto numero di nanoparticelle e nanomateriali ingegnerizzati in vari prodotti commerciali ed in quasi tutti i settori della società. Nonostante siano evidenti i molteplici vantaggi che questa relativamente nuova scienza ha portato alla nostra vita giornaliera, ancora poco si conosce sul potenziale rischio ambientale ed umano che l'applicazione di questa tecnologia comporta. Fra tutti vi è il potenziale rischio di rilascio di nanoparticelle e nanomateriali ingegnerizzati in ambienti acquatici, che pone dubbi sulla sicurezza di risorse utilizzate per la produzione di acqua potabile. In aggiunta, può creare problematiche relative all'ottimizzazione operazionale e controllo degli impianti di trattamento delle acque.

La ricerca presentata in questa tesi di dottorato intende analizzare la rimozione ed il meccanismo di rimozione di nanoparticelle e nanomateriali ingegnerizzati simulando impianti di trattamento dell'acqua potabile. La tesi si focalizza su come questi nuovi potenziali contaminanti possano influenzare le prestazioni di processo, e su quali siano i migliori trattamenti da seguire per la loro rimozione.

Nel Capitolo 2 si studia il ruolo della dimensione dei pori della membrana nella rimozione e meccanismo di rimozione di nanoparticelle fullerene $\mathrm{nC}_{60}$ in acqua ultra-pura, eseguita tramite sistemi di micro- e ultra- filtrazione. Sotto condizioni tipicamente impiegate in impianti industriali di trattamento dell'acqua, ossia sistemi di filtrazione dead-end a flusso constante con molteplici cicli di backwash, è stato possibile ottenere una rimozione di $\mathrm{nC}_{60}$ quasi completa. Tale rimozione è associata alle membrane con pori di grandezza media più piccola della particella (intesa come distribuzione) o di dimensione simile. Diversamente, membrane con pori di grandezza media più grande della dimensione delle particelle (intesa come distribuzione), hanno ottenuto una rimozione molto bassa di circa il 10\%. La rimozione di $\mathrm{nC}_{60}$ associato a membrane con pori di grandezza media più piccola della dimensione di $\mathrm{nC}_{60}$, 'e principalmente basato su meccanismo di esclusione sterica; mentre per membrane con pori di dimensione media paragonabili alla dimensione delle $\mathrm{nC}_{60}$, è stato identificato come una combinazione di blocco dei pori e formazione di uno strato di torta sulla membrane.

Un'alta efficienza di rimozione di $\mathrm{nC}_{60}$ con sistemi di micro-filtrazione può essere ottenuta anche a condizioni ambientali (Capitolo 3), specialmente quando queste nanoparticelle sono 
disperse in acque (pre-trattate) di superficie con differenti composizioni di materiale naturale organico e differenti concentrazioni di cationi divalenti. La composizione di acque superficiali non ha effetto sull'efficienza di rimozione di $\mathrm{nC}_{60}$, che è sempre più alta del 99.9\%. Durante il processo di micro-filtrazione si osserva comunque fouling della membrana, al quale è associato un aumento della pressione applicata considerevolmente più alto della semplice somma dell'aumento di pressioni applicate durante la filtrazione di $\mathrm{nC}_{60}$ in acqua ultra-pura e di acqua di superficie senza $\mathrm{nC}_{60}$. Questo effetto sinergico è particolarmente dominante quando è presente in acqua materiale naturale organico di carica negativa, e dipende meno della presenza di cationi divalenti. Si è ipotizzato che, durante la filtrazione di acque superficiali contenenti $\mathrm{nC}_{60}$, le nanoparticelle possano riempire gli spazi vuoti tra il materiale naturale organico depositato sulla superficie di membrane, cosi da portare ad una più bassa porosità dello strato di torta e quindi ad una più alta resistenza durante la filtrazione.

I risultati di efficienza di rimozione ottenuti in laboratorio sono stati validati su impianti pilota nel Capitolo 4. Gli studi sugli impianti pilota hanno mostrano un'alta efficienza di rimozione per nanoparticelle di argento e oro, nonostante la dimensione di queste sia più piccola della dimensione dei pori della membrana. Questo è in accordo con i risultati precedenti (Capitolo 2 e 3). Le osservazioni visive durante l'autopsia della membrana suggeriscono ancora una volta come il meccanismo di rimozione sia una combinazione di esclusione sterica e blocco dei pori. Tuttavia, l'evoluzione nel tempo della pressione applicata durante il processo di micro-filtrazione di nanoparticelle di argento e oro, è sostanzialmente piatto (sia su scala pilota che di laboratorio), diversamente da quello osservato durante la micro-filtrazione di $\mathrm{nC}_{60}$. Questo suggerisce che (i) la resistenza alla filtrazione dello strato di torta formato sulla superficie di membrane dipenda dalla natura delle nanoparticelle, oppure che (ii) la formazione di uno strato di torta senza il blocco dei pori.

Oltre a membrane di filtrazione a bassa pressione, questa tesi studia anche la rimozione e il meccanismo di rimozione di $\mathrm{nC}_{60}$ in processi di coagulazione-flocculazione-sedimentazione utilizzando cloruro di ferro come coagulante (Capitolo 5). Questo processo è meno affidabile di quello di filtrazione a membrane, con efficienze di rimozione che possono variare da $100 \%$ fino a $0 \%$. È stata individuata una buona correlazione tra la rimozione di $\mathrm{nC}_{60}$ da acqua ultrapura e l'idrolisi di $\mathrm{Fe}^{3+}$ in acqua, il quale è in grado di aumentare le prestazioni di rimozione 
attraverso meccanismi di neutralizzazione e destabilizzazioni della carica in condizioni acide. In condizioni basiche, la rimozione diminuisce drasticamente così come la concentrazione di prodotti di idrolisi cationici di $\mathrm{Fe}^{3+}$. Quando $\mathrm{nC}_{60}$ sono disperse in acqua superficiale, la materia di natura organica aumenta la rimozione $\mathrm{di}_{\mathrm{nC}_{60}}$ in condizioni acide tramite processi di co-precipitazione e ne diminuisce la rimozione in un intervallo di $\mathrm{pH}$ 6-8. Mentre la presenza di cationi divalenti destabilizza le $\mathrm{nC}_{60}$ aumentandone la loro rimozione nello stesso intervallo di pH. La presenza di materia naturale organica carica negativamente domina ancora gli effetti di stabilizzazione e inibisce la rimozione di $\mathrm{nC}_{60}$.

Nel Capitolo 6 viene studiata la rimozione di $\mathrm{nC}_{60}$ usando carboni attivi. Gli esperimenti di assorbimento isotermico hanno dimostrato che la rimozione di $\mathrm{nC}_{60}$ aumenta con l'aumento dell'area superficiale delle particelle di carbone attivo. Infatti i carboni attivi in polvere possono rimuovere completamente le nanoparticelle da acqua ultra-pura, se utilizzate in dose adeguata; mentre la rimozione di $\mathrm{nC}_{60}$ risulta essere molto meno efficiente quando sono utilizzati carboni attivi granulari. Tuttavia, in condizioni più rappresentative del trattamento delle acque (filtrazione di $\mathrm{nC}_{60}$ tramite una colonna contenente carboni attivi granulari), la ritenzione di $\mathrm{nC}_{60}$ è considerevolmente più alta $(\sim 90 \%)$. Pertanto i risultati ottenuti dall' assorbimento isotermico di nanoparticelle dovrebbero essere trattati con cautela, in quanto queste misurazioni si basano sul concetto di equilibrio termodinamico e non includono effetti cinetici e di destabilizzazione che occorrono durante la filtrazione.

Infine, nel Capitolo 7 vengono riassunte le conclusioni di questo lavoro e si suggeriscono direzioni future per la ricerca in questo campo. 



\section{CONTENTS}

Summary ix

Samenvatting XV

Sommario xix

Contents xxiii

1 Introduction 27

$1.1 \quad$ Nanotechnology 28

1.2 Application of engineered nanomaterials and nanoparticles and their release in the environment 29

1.3 Toxicity of eNPs__ 35

1.4 Removal, fate and behaviour in water treatment plants___ 37

1.4.1 Coagulation flocculation sedimentation__ 38

1.4.2 Membrane filtration _ 39

1.5 Problem definition _ 41

1.6 Thesis organization and outline ___ 42

References__ 44

2 Removal of aqueous $\mathrm{nC}_{60}$ fullerene from water by low pressure membrane filtration 51

2.1 Introduction _ 53

2.2 Theory__ 55

2.3 Material and Methods__ 58

2.3.1 Reagents and Chemicals__ 58

2.3.2 Preparation of aqueous fullerene dispersions _ 58

2.3.3 Characterization of aqueous fullerene dispersion size _ 58

2.3.4 Membrane and membrane characterization _ 59

2.3.5 Membrane filtration apparatus and filtration procedure __ 61

2.3.6 Data handling___ 62

2.4 Results and discussion___ 64

2.4.1 Characterization of $\mathrm{nC}_{60}$ dispersions __ 64

2.4.2 Clean water flux measurements __ 65

2.4.3 Removal efficiency ___ 66

2.4.4 TMP and permeability recovery (backwash efficiency) _ 69

2.4.5 Application of the blocking laws for constant flux low pressure membrane filtration 77 
2.4.6 Discussion overall filtration behaviour under typical full-scale conditions 78

2.5 Conclusion _ 79

Acknowledgement __ 80

References__ 81

3 Effect of multicomponent fouling during microfiltration of natural surface waters containing $\mathrm{nC}_{60}$ fullerene nanoparticles

3.1 Introduction __ 87

$3.2 \quad$ Materials and methods___ 90

3.2.1 Reagents and Chemicals__ 90

3.2.2 Preparation and characterization of $\mathrm{nC}_{60}$ dispersions ___

3.2.3 Preparation and characterization of water type backgrounds ___ 92

3.2.4 Membrane and membrane characterization ___ 93

3.2.5 Filtration set-up and procedure __ 93

3.2.6 Data handling __ 95

3.3 Results and discussion___ 96

3.3.1 Water quality parameters___ 96

3.3.2 $\mathrm{nC}_{60}$ size and zeta potential___ 98

3.3.3 Filtration behaviour of $\mathrm{nC}_{60}$ in different water backgrounds___ 99

3.3.4 Removal and fouling mechanism_ 104

3.4 Conclusions _ 107

Acknowledgement ___ 108

References__ 109

3.5 Supporting information ___ 115

3.5.1 Filtration and fouling of surface water without $\mathrm{nC}_{60} \quad 115$

3.5.2 Membrane rejection __ 117

3.5.3 Fouling development (pressure profiles) in the presence of $\mathrm{nC}_{60}$

3.5.4 Fouling development (pressure profiles) in the absence of $\mathrm{nC}_{60} \_120$

4 Removal of engineered nanoparticles from water by low-pressure membrane filtration - pilot scale validation___ 123

4.1 Introduction _ 125

4.2 Material and Methods__ 128

4.2.1 Reagents and Chemicals__ 128

4.2.2 Preparation of eNPs dispersions for filtration 128

4.2.3 Characterization of eNPs size 128

4.2.4 Membrane and membrane characterization __ 130

4.2.5 Membrane filtration process and filtration procedure__ 130

4.3 Results and discussion__ 132

4.3.1 Water composition___ 132 
4.3.2 Characterization of silver and gold eNPs dispersions

4.3.3 Removal efficiency

4.4 Conclusions

Acknowledgement 139

References 140

4.5 Supporting information 143

5 Removal of aqueous $\mathrm{nC}_{60}$ fullerene from water by coagulation, flocculation and sedimentation

5.1 Introduction 147

5.2 Theory 154

5.3 Materials and methods 156

5.3.1 Reagents and chemicals 156

5.3.2 Preparation and characterization of fullerene suspensions 156

5.3.3 Water types 157

5.3.4 Simulation of the coagulation-flocculation-sedimentation processes 159

5.4 Results and discussion__ 160

5.4.1 Removal efficiency on ultrapure water__ 160

5.4.2 Removal efficiency on pre-filtered surface water___ 163

5.4.3 The role of NOM and divalent cations ___ 164

5.5 Conclusions _ 167

Acknowledgement__ 168

References__ 169

6 Removal of aqueous $\mathrm{nC}_{60}$ fullerene from water by adsorption on powdered and granular activated carbon

6.1 Introduction _ 175

6.2 Material and Methods__ 179

6.2.1 Preparation of aqueous fullerene dispersions _ 179

6.2.2 Characterization of aqueous fullerene dispersions _ 179

6.2.3 Surface water characterization 180

6.2.4 Powdered and granular activated carbon__ 180

6.2.5 Attachment efficiency _ 182

6.2.6 PAC adsorption _ـ 183

6.2.7 GAC adsorption 183

6.2.8 Column study ___ 184

6.3 Results and discussion___ 185

6.3.1 Removal efficiency of PAC in ultrapure water in batch tests___ 185

6.3.2 Removal efficiency of GAC in ultrapure water in batch tests __ 186 
6.3.3 Removal efficiency of GAC in surface water 188

6.3.4 Removal efficiency of GAC (column experiment) 190

6.3.5 Overall removal efficiency of $\mathrm{nC}_{60}$ by $\mathrm{AC}$ 191

6.4 Conclusions 193

Acknowledgement 193

References 194

7 Conclusions and outlook 199

7.1 Conclusions 200

$7.2 \quad$ Outlook 204

Acknowledgements 207 
1 INTRODUCTION 


\subsection{Nanotechnology}

Nobel laureate physicist Richard Feynman was one of the first to recognize the potential of nanotechnology for our society in 1960. With his lecture "There's Plenty of Room at the Bottom", given at the California Institute of Technology during a meeting with the American Physical Society, he first mentioned the process that could potentially manipulate individual atoms/molecules and hence advance the field of synthetic chemistry (Feynman, 1960). This process nowadays is known as nanotechnology and is concerned with manufacturing to dimensions or tolerances in the range of 0.1-100 nm (Franks, 1987). More specifically, according to the American Society for Testing and Materials, nanotechnology is a term referring to a wide range of technologies that measure, manipulate, or incorporate materials and/or features with at least one dimension between approximately 1 and $100 \mathrm{~nm}$. These technologies exploit the properties of nanoscale components (ASTM Standard E2456, 2012) which are distinct from bulk/macroscopic systems. The specific properties of nanoparticles differ from non-nanoscale materials with the same chemical composition in terms of the percentage of surface atoms, which increases with decreasing particle size (Auffan et al., 2009). For particles with dimensions in the range of microns, less than $1 \%$ of the atoms is located at the particle surface, while for particles with a diameter of $10 \mathrm{~nm}$, the percentage of atoms occupying the particle surface is $10 \%$. If the particle size is further decreased to $2 \mathrm{~nm}$, $60 \%$ of the atoms is located at the particle surface and is in contact with the environment. As particle size decreases and the percentage of surface atoms increases, the reactivity of the material can increase dramatically (Pan and Xing, 2010a). Another example is the melting temperature of the particles as a function of the diameter: a decrease in the particle diameter from 50 to $20 \mathrm{~nm}$ reduces the melting temperature from about $230{ }^{\circ} \mathrm{C}$ to $220^{\circ} \mathrm{C}$; if the particle size is further decreased to $10 \mathrm{~nm}$ the melting temperature reduces to $200{ }^{\circ} \mathrm{C}$; an additional decrease of the size to $5 \mathrm{~nm}$ will bring the melting temperature down to $150{ }^{\circ} \mathrm{C}$ even (Auffan et al., 2009). These few examples already show the distinctively different behaviour of nanoparticles compared to bulk materials. 


\subsection{Application of engineered nanomaterials and}

\section{nanoparticles and their release in the environment}

In the last 40 years nanotechnology received an increased attention from the research community. A simple electronic search conducted in the Scopus database (www.scopus.com) resulted in more than 430,000 documents published over the period 1978 - 2015 and containing at least one of the following keywords: nanotechnology, nanomaterials, nanoparticles or nanostructure (Figure 1-1).

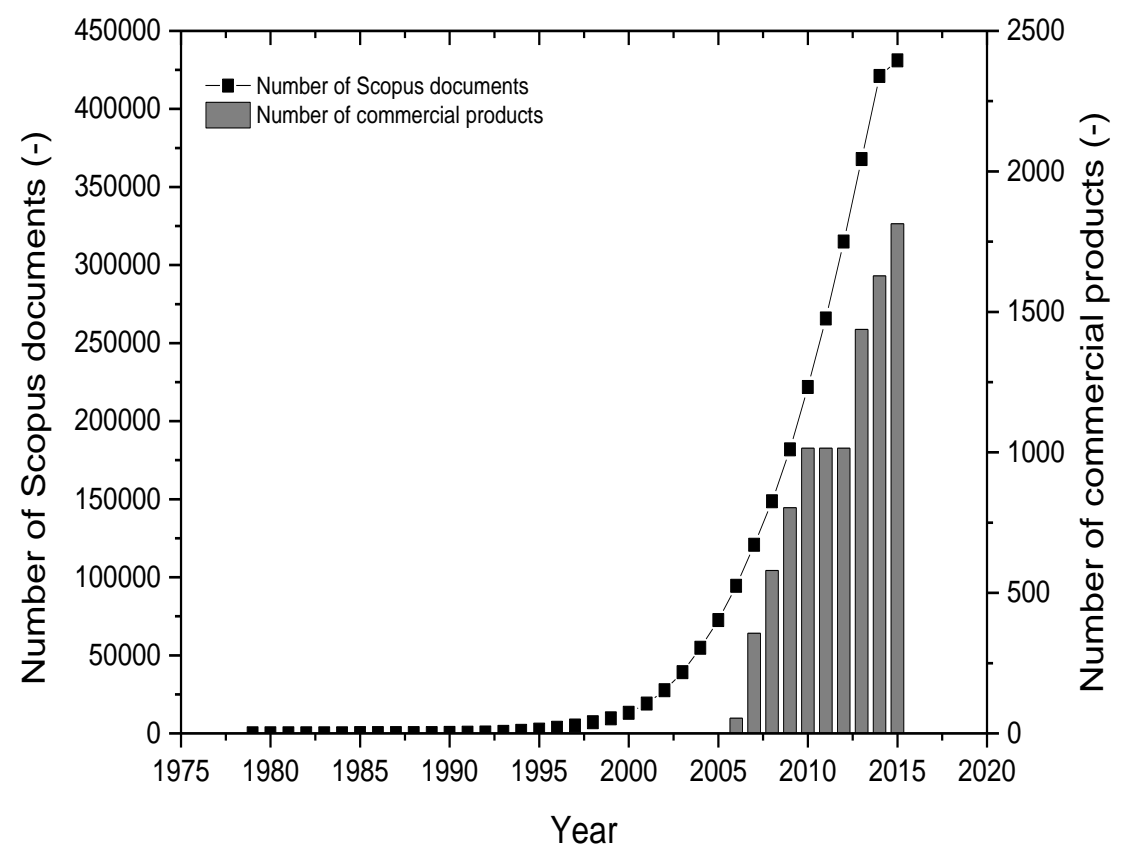

Figure 1-1: Left Y-Axis: Cumulative number of documents in time containing at least one of the following keywords: nanotechnology, nanomaterials, nanoparticles and nanostructure according Scopus (www.scopus.com consulted on March, 3rd 2016); Right Y-axes: number of products in time containing engineered nanomaterials according the Nanotechnology Consumer Product Inventory (Vance et al., 2015).

Consequently, a large and continuously increasing number of manufactured or engineered nanoparticles and nanomaterials (eNPs) finds its way to applications in almost every sector 
of society and in multiple daily products (e.g. titanium dioxide in sunscreens, fullerene in cosmetics and medicines, silver in wound dressings, textiles or large appliances as antibacterial). In Figure 1-1 also the number of products containing engineered eNPs according the Nanotechnology Consumer Product Inventory

$\left(\mathrm{NCPI}^{1}\right)$ is reported (Vance et al., 2015). The NCPI is the largest online inventory of nanotechnology consumer products available and lists 1,814 products as of March 2015, coming from 622 companies located in 32 countries. The products listed on the NCPI satisfy three criteria: (1) they can be purchased by consumers; (2) they are claimed by the manufacturer or another source to contain eNPs; and (3) they claim to contain eNPs that appear reasonable to the NCPI curatorial staff.

Until now eNPs have been used widely in cosmetics and personal care products, clothing, biology, nanomedicines, microelectronics, energy, food and food packaging, paints and coatings, catalysts, automotive, lubricants and fuel additives, water treatment and soil/water/bioremediation (Srivastava et al., 2015; Vance et al., 2015).

Some examples include titanium dioxide $\left(\mathrm{TiO}_{2}\right)$ eNPs, which are used as antimicrobial, antibiotic and antifungal agents, as ultraviolet (UV) blockers, anti-scratch additives and catalysts (French et al., 2009). Specific products are sunscreens, coatings, plastics, soaps, bandages, alloys, textiles, paint and toothpaste (Chen and Mao, 2007; French et al., 2009). As a colour additive $\mathrm{TiO}_{2}$ eNPs can be found in food, drugs, cosmetics, and contact lenses (French et al., 2009). Silver (Ag) is another largely used eNPs in consumer products. Due to its strong antibacterial activity, Ag eNPs coatings are used in various textiles (Geranio et al., 2009) for treatment of wounds and burns, as a water disinfectant, room spray (Chen and Schluesener, 2008), as pigments in façade paints (Kaegi et al., 2010) and in home appliances for water treatment (Tolaymat et al., 2010). Among the carbonaceous eNPs, buckminsterfullerene $\left(\mathrm{C}_{60}\right)$ (Kroto et al., 1985) is one of the most applied. $\mathrm{C}_{60}$ is used in different applications, e.g. cosmetics (Reisch, 2009), biological and medical applications (Bakry et al., 2007; Jensen et al., 1996) and plastic solar cells (Brabec et al., 2001) due to its

\section{${ }^{1}$ http://www.nanotechproject.org/cpil}




\section{Chapter 1}

specific physical and chemical properties i.e. heat resistance, conductivity and electronacceptor capability (Guldi and Prato, 2000).

The definition of eNPs involves three criteria: (1) nanoscale sizes $(1-100 \mathrm{~nm})$; (2) manmade nature ('engineered'); and (3) containing properties that can only arise because of the nanoscopic dimensions (Theis et al., 2006). eNPs can be engineered as: nanosheets with a nanoscale in one dimension, nanorods and nanotubes with a nanoscale in two dimensions, and nanoparticles and nanoparticulate matter with a nanoscale in three dimensions in the range of $<100 \mathrm{~nm}$ ) (Srivastava et al., 2015).

Given the increasing rate of eNPs production and application, their release in the environment will increase and subsequent effects on the environment and personal health will become an increasing concern that needs to be addressed (Ray et al., 2009). Particularly the release into aquatic environments will, next to the exposure of aquatic living organisms to eNPs, be a threat for the security of surface and underground resources used for drinking water production. There are multiple pathways through which eNPs can be introduced into the environment (Figure 1-2) (Nowack and Bucheli, 2007; Pan and Xing, 2010a).

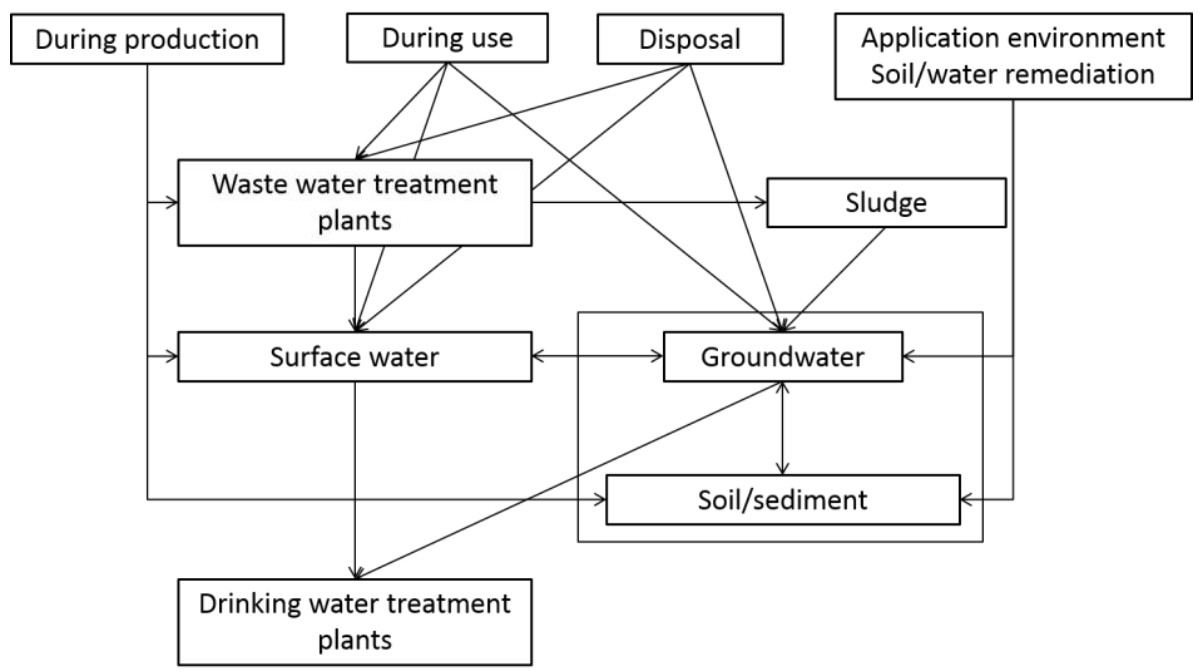

Figure 1-2: eNPs release pathways into the environment including sources for drinking water production (adapted from Nowack and Bucheli, 2007; Pan and Xing, 2010). 
These pathways include release during production, during use or after disposal and depend primarily on the full life cycle of (products containing) eNPs that (Gottschalk and Nowack, 2011; Som et al., 2010).

The emission to the environment can occur when eNPs are introduced in the environment with a specific purpose, e.g. for remediation of water and soil. eNPs used for remediation of water and soil (contaminated by heavy metals, nitrogen and some persistent organic pollutants), such as zero-valent iron, zeolites, metal oxides and carbon materials are likely to cause direct emissions into water bodies (Klaine et al., 2008; Sánchez et al., 2011; Stefaniuk et al., 2016).

Release can also occur when eNPs end-up in the environment as a consequence of their production, use or disposal and this without a specific purpose. For instance, eNPs contained in sunscreen can be introduced directly to water bodies during swimming or bathing (Gondikas et al., 2014; Gottschalk and Nowack, 2011). Different studies proved that Ag eNPs can be released from textiles during washing (Benn and Westerhoff, 2008; Rezić, 2011) or that $\mathrm{Ag}$ and $\mathrm{TiO}_{2}$ eNPs can be released from exterior facade paints (Kaegi et al., 2010, 2008). These eNPs can ultimately reach natural waters directly by runoff or indirectly if not retained in waste water treatment plants (WWTPs) (Ganesh et al., 2010; Kiser et al., 2009; Westerhoff et al., 2011). Moreover eNPs retained in the settling solid sludge of WWTPs can find a way to the soil and water bodies if the biomass is reused as fertilizer in landfills and agriculture soil (Kiser et al., 2009). Accidental release during manufacturing processes or transport is also possible (Nowack and Bucheli, 2007). Gottschalk and Nowack (2011) estimated an accidental release between 0.1 to $2 \%$ of the total production of eNPs to the environment during manufacturing (Keller et al., 2013). Other predictions indicate that globally 66,000 tons of eNPs are directly released to surface waters every year (Garner and Keller, 2014; Keller et al., 2013) regardless of being introduced in the environment with or without intention. The concentrations of eNPs in water environments are expected to be low still, ranging from $\mathrm{ng} / \mathrm{l}$ to $\mu \mathrm{g} / \mathrm{l}$ (Table 1-1). However the data reported are mainly based on calculations due to the lack of methodology for the detection and characterisation of eNPs in complex matrices, i.e. water, soil or food (Tiede et al., 2008). 


\section{Chapter 1}

Moreover the methodologies used for the calculation of environmental release of eNPs vary considerably in model conceptualization, parameterization as well as to model input data collection (Gottschalk and Nowack, 2011).

Nonetheless the concentration of eNPs in the environment is expected to increase in the coming years due to the continuously increasing production, use and disposal (Hendren et al., 2011). 
Table 1-1: Summary of concentrations (measured and calculated) for selected eNPs in aquatic systems (adapted from Wu, Wyart, Liu, Rose, \& Moulin, (2013)).

\begin{tabular}{lllll}
\hline eNPs & $\begin{array}{l}\text { Surface water } \\
(\mu \mathrm{g} / \mathbf{l})\end{array}$ & $\begin{array}{l}\text { WWTP } \\
\text { effluents } \\
(\mu \mathrm{g} / \mathbf{l})\end{array}$ & $\begin{array}{l}\text { Run-off } \\
(\mu \mathrm{g} / \mathbf{l})\end{array}$ & $\begin{array}{l}\text { Sediment } \\
(\boldsymbol{\mu g} / \mathbf{k g})\end{array}$ \\
\hline $\mathrm{Ag}$ & $0.0001-0.08$ & $0.016-0.127$ & $0.5-145$ & $0.153-10.18$ \\
$\mathrm{Ti}^{\mathrm{TiO}}{ }_{2}$ & $0.002-6.48$ & $1.37-25$ & $8-16$ & $44-6330$ \\
$\mathrm{ZnO}$ & $0.001-76$ & $0.22-1.42$ & - & $0.49-56$ \\
$\mathrm{CeO}_{2}$ & $<0.0001$ & - & - & - \\
$\mathrm{Al}_{2} \mathrm{O}_{3}$ & 0.0002 & - & - & - \\
$\mathrm{Fullerenes}$ & $2.4 \cdot 10^{-6}-0.31$ & $0.0037-0.033$ & - & $0.001-0.787$ \\
$\mathrm{Silica}_{\mathrm{Carbon}}$ & 0.0005 & - & - & - \\
& $6 \cdot 10^{-7}-0.0008$ & $0.0066-0.315$ & - & $0.04-1.557$ \\
\hline
\end{tabular}

Once eNPs find their way into the environment, their fate and transport in water largely depends on the physical and chemical properties of the water, which affect their persistence in the aquatic environment. Differences in water composition can impact the rate of transport processes such as aggregation, sedimentation, dissolution, adsorption/desorption in other water constituents (i.e. natural organic matter), oxidation and sulfidation (Garner and Keller, 2014). Particularly natural organic matter (NOM), a complex mixture composed of different organic materials (Sillanpää, 2015) and divalent cations such as calcium and magnesium play a critical role in eNPs stability (K.L. Chen et al., 2010). Investigations on the effects of NOM on the aggregation of eNPs indicate that the presence of NOM in water can impart more negative charges to the surface to the eNPs surface (Philippe and Schaumann, 2014) resulting in a diminished aggregation of the eNPs, thus increasing their colloidal stability (Grillo et al., 2015). Stabilization of eNPs by NOM (i.e. surface coating) can cause them to remain in the bulk of the water and increases the interparticle distance (Christian et al., 2008). Also the ionic strength of the water influences the properties of the particles in water: the presence of multivalent cations induces aggregation of the eNPs because of electrical double layer compression and thus enhances destabilization and aggregation (Duan \& Gregory, 2003), which can ultimately lead to eNPs deposition (Philippe \& Schaumann, 2014). 


\section{Chapter 1}

\subsection{Toxicity of eNPs}

Release of eNPs to the environment and to sources for drinking water has raised questions on their toxicity to biota and humans. Different studies show that eNPs are taken up by a wide variety of mammalian cell types (Behra and Krug, 2008; Scown et al., 2010). They are able to cross the cell membrane and can be internalized in living bodies (Nowack and Bucheli, 2007). Toxic effects of eNPs have been observed for a wide ranges of eNPs concentrations and for a variety of species (Sharifi et al., 2012; Srivastava et al., 2015). Three main causes of eNPs toxicity following contact with living cells have been identified (Kirchner et al., 2005): (i) the chemical toxicity of materials from which they have been made; (ii) the small size of eNPs which may allow them to stick to cellular membranes and enter the cells; (iii) the shape of eNPs: i.e. carbon nanotubes can puncture and break cell membranes. The toxicity of eNPs is further affected by their composition, much like for the parent bulk materials. However, additional physicochemical properties play a crucial role in determining the toxicity of eNPs, such as size, surface chemistry, shape, protein absorption and surface smoothness or roughness (Sharifi et al., 2012). As eNP size decreases, the surface area exponentially increases as well as does the percentage of the atoms located at the surface (Auffan et al., 2009). The eNP surface becomes more reactive towards other eNPs or surrounding biological components with decreasing size (Sharifi et al., 2012). Also, the shape of the eNPs plays a role in relation to their toxicity. Carbon nanotubes are an allotrope of carbon with a cylindrical shape. They have been found to act much like asbestos in the lungs of rats raising concerns that exposure to them may lead to pleural abnormalities such as mesothelioma (Poland et al., 2008). Other shapes of carbon-based eNPs such as fullerene $\mathrm{C}_{60}$ appear to be less toxic (Oberdörster et al., 2005) due to their spherical shape. The surface chemistry of $\mathrm{C}_{60}$, however, can also influence its toxicity: fullerene $\mathrm{C}_{60}$ demonstrated significant toxicity in cell culture studies, while a surface functionalized (hydroxylated) $\mathrm{C}_{60}(\mathrm{OH})_{24}$ did not (Sayes et al., 2005). The absorption of proteins and biomolecules to the high reactive surfaces of eNPs forms in biological systems a new "biological identity", which determines the subsequent cellular and tissue responses (Lynch and Dawson, 2008; Sharifi et al., 2012). These proteins adsorbed form a so called "protein corona" and serve as key mediators in the interaction between eNPs and the surrounding cells controlling complex 
phenomena such as cellular uptake of eNPs, their biodistribution and cellular responses in vivo (Mahmoudi and Serpooshan, 2011). Slight variations in eNP surface properties (e.g. surface roughness) can cause significant changes in the composition of the proteins adsorbed, and thus in the corresponding cellular responses (Mahmoudi and Serpooshan, 2011).

In order to understand the risk posed by eNPs in water, it is necessary to understand both the dose response effect of eNPs as well as the exposure pathway. To estimate the level of risk that eNPs pose in water the results of 61 different eNPs ecotoxicity studies were compared with the predicted release concentrations in freshwater and seawater media (Table 1-2) (Garner and Keller, 2014). According to the authors (Garner and Keller, 2014), the risk can be categorized in 5 categories based on maximum predicted environmental concentrations and toxicity to the most sensitive aquatic species. The 5 categories of risk reported in Table 1-2 range from toxic at maximum predicted environmental concentrations to non-toxic at all tested concentrations.

Table 1-2: Toxicity of eNPs in freshwater and seawater (Garner \& Keller, (2014))

\begin{tabular}{|c|c|c|}
\hline & Fresh water & Sea water \\
\hline No toxicity observed & $\mathrm{SiO}_{2}$ & $\begin{array}{l}\mathrm{FeO} / \mathrm{Fe}_{2} \mathrm{O}_{3} \text {, Single-walled } \\
\text { Carbon-Nanotubes }\end{array}$ \\
\hline Toxic at $<10 \mathrm{mg} / \mathrm{l}$ & $\begin{array}{l}\mathrm{Al}_{2} \mathrm{O}_{3}, \mathrm{CeO}, \mathrm{Cu} / \mathrm{CuO}, \mathrm{C}_{60}, \\
\mathrm{Fe}_{3} \mathrm{O}_{4}, \mathrm{Latex}, \mathrm{NiO}, \mathrm{TiO}_{2}, \\
\text { Carbon-Nanotubes }\end{array}$ & $\mathrm{Au}, \mathrm{CeO}_{2}, \mathrm{CuO}, \mathrm{C}_{60}, \mathrm{SiO}_{2}$ \\
\hline Toxic at $>10 \mathrm{mg} / \mathrm{l}$ & $\mathrm{Au}, \mathrm{FeO} / \mathrm{Fe}_{2} \mathrm{O}_{3}$ & $\begin{array}{l}\mathrm{Al}_{2} \mathrm{O}_{3}, \mathrm{Cr}_{2} \mathrm{O}_{3}, \mathrm{NiO}, \mathrm{TiO}_{2}, \\
\text { Multi-walled Carbon- } \\
\text { Nanotubes }\end{array}$ \\
\hline $\begin{array}{l}\text { Toxic at } 100 x \text { the } \\
\text { environmentally relevant } \\
\text { concentration }\end{array}$ & Ag, nZVI, ZnO & $\mathrm{Ag}, \mathrm{nZVI}, \mathrm{ZnO}$ \\
\hline
\end{tabular}

The eNPs concentrations considered by Garner \& Keller ranged from the low ng/l to mg/l. At current predicted release quantities and using the results of current toxicity tests, none of the considered eNPs seems to cause aquatic toxicity. Nonetheless the removal of eNPs in drinking water treatment plant has to be evaluated carefully since: (i) most of the studies focused on toxicity of eNPs to aquatic organisms and not to soil organisms or more importantly human cells; (ii) the concentrations used in the review (Garner and Keller, 2014) 


\section{Chapter 1}

are the outcome of calculation studies and have a high degree of uncertainty due to the different methodologies used in the modelling approaches (Gottschalk and Nowack, 2011) and therefore might be actually higher than expected; (iii) in addition there will be likely some hotspots and other exceptions where the concentration of eNPs can reach considerably high levels (up to $10 \mathrm{~g} / \mathrm{l}$ ). Such as hotspots can be easily identify where eNPs are released in the environment for remediation (Grieger et al., 2010), or as a result of accidental spilling during manufacturing (Mueller and Nowack, 2008) or in areas close to points of release (i.e. wastewater effluent discharge) (Garner and Keller, 2014).

Ultimately, due to the high surface reactivity (Stone et al., 2010), eNPs in water can behave as a carrier for other kinds of pollutants, such as viruses, hydrophobic organic micropollutants or certain heavy metals (Hofmann and von der Kammer, 2009; Navarro et al., 2008; Stone et al., 2010). These interactions will ultimately affect potable water quality. In this perspective, the removal of eNPs during water treatment plant operation is a priority for the production of safe drinking water.

\subsection{Removal, fate and behaviour in water treatment}

\section{plants}

As discussed above, in the light of uncertainties regarding environmental concentrations and toxicity effects on humans, eNPs in sources for drinking water pose a potential threat to the production of safe drinking water. Next to the above-mentioned toxicity, they can have a significant impact on many aspects of water treatment processes (i.e. the performance of unit processes, necessity for and application of water treatment chemicals) posing challenges to water treatment facilities in terms of operational optimization and proper process control.

The behaviour of eNPs in aqueous environments is often comparable to the one of colloids in water (Baalousha et al., 2011; Kim et al., 2006; Lead and Wilkinson, 2006). Therefore, it can be expected that they are removed by conventional treatment processes such as coagulation-flocculation-sedimentation and advanced treatments such as low pressure membrane filtration. In fact, over the past few years, several publications appeared reporting 
on the effectiveness in removing eNPs from water with coagulation and flocculation (Hyung and Kim, 2009; C. Wang et al., 2013a, 2013b; Zhang et al., 2014) and low pressure membrane filtration (Floris et al., 2016; Henry and Brant, 2012; Henry et al., 2012; Trzaskus et al., 2015).

\subsubsection{Coagulation flocculation sedimentation}

In conventional treatment plants, impurities from water, such as colloidal and suspended particles, are usually effectively removed by coagulation and flocculation followed by sedimentation or filtration (Duan and Gregory, 2003). Coagulation involves the addition of chemical coagulants such as aluminium sulphate, iron salts and/or organic polymers, resulting in the destabilization of negatively charged suspended colloids in water. The following step, flocculation, is the aggregation of destabilized particles to larger particles, commonly known as flocs, which are finally removed by sedimentation and/or filtration processes.

Removal efficiencies of eNPs applying coagulation-flocculation-sedimentation (CFS) processes were investigated in several studies. The list of eNPs studied includes TiO2 $(\mathrm{H}$. Wang et al., 2013; Wang et al., 2014), $\mathrm{Fe}_{2} \mathrm{O}_{3}$, ZnO, NiO (Yang Zhang et al., 2008), silica (Chang et al., 2007; Yang Zhang et al., 2008), multi-walled carbon nanotubes (CNTs) (He et al., 2012; Holbrook et al., 2010; Liu et al., 2012), quantum dots (QDs) (Y. Zhang et al., 2008), Ag (Sun et al., 2013) and $\mathrm{C}_{60}$ (Hyung and Kim, 2009; C. Wang et al., 2013a, 2013b; Zhang et al., 2014). The removal efficiencies reported in these studies varied significantly being $70 \%, 80 \%$ and $90 \%$ for $\mathrm{TiO}_{2}, \mathrm{Ag}$ and CNTs respectively. Silica eNPs were not effectively removed (removal efficiency lower than $60 \%$ at $\mathrm{pH}$ 7) by poly aluminum chloride coagulation (Chang et al., 2007) nor by alum (Yang Zhang et al., 2008). Alum removal efficiency of commercial QDs (Y. Zhang et al., 2008) was about 70\% at pH 8.

The removal efficiency of eNPs and the variation thereof depends on the colloidal stability, the water chemistry, the eNPs type and concentration and the coagulant type and dosage. The removal efficiency dependency on water chemistry was found to be in agreement with previous studies on eNPs stability in water (Kai Loon Chen et al., 2010): the presence of electrolytes increases the size of the eNPs because of electrical double layer compression 


\section{Chapter 1}

(Yang Zhang et al., 2008) enhancing destabilization, aggregation and thus removal. On the other hand the presence of humic acids (HA) greatly decreases the removal rate of eNPs (Hyung and Kim, 2009; Wang et al., 2014) because of the steric hindrance effects of HA molecules and the additional negative charge imparted to the eNPs.

Although chemical coagulation and flocculation processes favour a rapid increase in particle size and facilitate an easy removal of particles, the complete removal of eNPs might not always be assured because this is strongly affected by the water composition (alkalinity, electrolyte and natural organic matter (NOM) concentration) and the specific interactions (e.g. electrostatic) between eNPs and e.g. surfactants and the type of coagulant (Holbrook et al., 2010). For example, carbon nanotubes stabilized with organic matter are significantly removed (removal $\sim 80 \%$ ) by CFS with ferric chloride coagulant at neutral $\mathrm{pH}$. However the removal is drastically hindered $(\sim 50 \%)$ when the carbon nanotubes are surfactant stabilized (Holbrook et al., 2010). The exact mechanism of stabilization is unknown since the used surfactants are a tailored blend of proprietary materials.

Holbrook et al. (2010) found that ferric chloride and alum coagulants can remove carbon nanotubes during the CFS process with maximum removal efficiencies of approximately $80 \%$ and $95 \%$ respectively at neutral $\mathrm{pH}$. However, to reach such levels of removal of carbon nanotubes, it is required that the iron concentration is four times higher than the alum concentration. Instead when iron and alum concentrations are nearly equivalent, alum provides a higher removal compared to ferric chloride because, at the neutral $\mathrm{pH}$, alum has higher concentrations of positively charged species compared to ferric chloride.

\subsubsection{Membrane filtration}

Membrane filtration is an important and relatively recent set of processes used for drinking water production. Currently, there are very few drinking water contaminants that cannot be removed economically by membrane filtration (Edzwald, 2011). Particularly low pressure membrane processes such as microfiltration and ultrafiltration are a viable solution for the removal of contaminants that are similar in size to colloidal eNPs i.e. turbidity causing species, pathogens, viruses, proctozoa cysts (Edzwald, 2011; Guo et al., 2010) and colloids (Schafer, 2000). 
In terms of eNP filtration, an earlier study showed removal efficiencies lower than $80 \%$ when filtering fullerene dispersions $\left(\mathrm{nC}_{60}\right.$ and fullerol) through $20 \mathrm{~nm}$ ceramic membranes under variable ionic strength, ionic composition and pressure gradients (Jassby et al., 2010). Fullerenes removal from the aqueous dispersion depended on the solution ionic strength, while transmembrane pressure only affected the retention of fullerol. Fullerene $\mathrm{nC}_{60}$ can be removed ( $\sim 80 \%$ ) during constant pressure filtration and the removal does not depend on the transmembrane pressure applied during filtration in the pressure range $0.05-0.4$ bar. Fullerol (functionalized fullerene $\left(\mathrm{C}_{60}(\mathrm{OH})_{24}\right)$ ) is significantly more sensitive to the applied transmembrane pressure, exhibiting a marked decrease in removal efficiency from $60 \%$ to $40 \%$ when the transmembrane pressure exceeded 0.05 bar. This difference in the removal efficiency between the two fullerene types was attributed to a weaker aggregate binding strength for the fullerol that allowed for deformation or breakup at the entrance of the membrane pores (Jassby et al., 2010). Interestingly, the removal efficiency of the fullerol is increased $(\sim 80 \%)$ when the solution ionic strenght is increased by the addition of divalent cations $\left(\mathrm{Ca}^{2+}\right.$ and $\left.\mathrm{Mg}^{2+}\right)$. The effect of the removal in function of $\mathrm{pH}$ was not studied by Jassby et al (2010).

The interactions between a set of eNPs and polymeric membranes composed of different materials and with different pore sizes (ranging from $2 \mathrm{~nm}$ to $200 \mathrm{~nm}$ ) were investigated as well (Ladner et al., 2012). The authors observed in general (i) a dependency of the particle size to membrane pore size ratio on the removal efficiency with size exclusion as predominant removal mechanism and (ii) that removal mechanisms were influenced by the surface affinity between eNPs and membrane, facilitating also the removal of eNPs smaller in size than the membrane pores when membrane and eNPs showed opposite surface charge. It was concluded that eNPs can be retained through size exclusion when their size is larger than the membrane pore sizes or, if smaller, by adsorption or adhesion to membrane surfaces, electrostatic interactions or removal mechanisms like pore blocking and cake layer formation (Ladner et al., 2012).

The eNP size distribution of eNPs can also affect the removal efficiency (Wang and Lim, 2012). It was found that larger $\mathrm{TiO}_{2}$ eNPs were able to form a cake layer on the membrane surface, which could promote the further rejection of smaller $\mathrm{TiO}_{2}$ eNPs (Wang and Lim, 2012). Although fouling formation can increase the overall removal of eNPs, it also leads to 


\section{Chapter 1}

severe flux decline, which hinders membrane applicability and increases operating costs. In addition fouling induced by eNPs occuring during cross-flow microfiltration was shown to be more persistent to conventional cleaning protocols than classical colloid fouling (Henry et al., 2012). The ineffectiveness of these cleaning solutions is attributed to hindered mass transfer through the denser eNP cake layer compared to colloidal cake-layers and/or to inability to effectively manipulate the stronger bonds between the eNPs themselves and those with the membrane surface. However Henry et al. (2012b) did not show any results on removal efficiency.

Although the aforementioned studies provided valuable knowledge on the interactions between eNPs and low pressure membranes, the results are difficult to translate to real water treatment plants because are performed with a variety of membranes, however of little relevance for the water industry, e.g. polycarbonate track-etched membranes, centrifugal membrane filters and syringe filters (Ladner et al., 2012). When relevant membrane configurations were considered such as flat sheet or hollow fiber membrane (Henry and Brant, 2012; Trzaskus et al., 2015), these researches neglected the operational conditions most commonly used in full-scale water treatment applications i.e. operation in constant flux mode including a backwash cleaning procedure (Crozes et al., 1997; Howe et al., 2007; Tarabara et al., 2002).

\subsection{Problem definition}

As briefly discussed above, the potential risk associated with the presence of eNPs in water sources poses a significant threat to the production of safe drinking water. In addition it creates challenges to water treatment facilities in terms of operational optimization and proper process control. The overall goal of this thesis is to provide more insight into the effects of presence and removal of eNPs in current water treatment processes. It systematically investigates the removal and removal mechanisms of eNPs in simulated drinking water treatment plants. The research focuses on how these new potential pollutants affect process performances and which treatments are best to follow for the removal of eNPs in water treatment plants. 
Specific objectives in pursuit of this goal are:

- To investigate the role of membrane pore size on the removal and removal mechanisms of eNPs in low pressure membrane filtration;

- To investigate the combined effect of natural surface water and eNPs on fouling of microfiltration membranes;

- To obtain a fundamental understanding of the fate and behaviour of eNPs in water treatment plants conducting the research under typical industrial operation and environmentally relevant conditions.

- To investigate the role of the stability of eNPs on the removal efficiency in a coagulation-flocculation-sedimentation process in different water compositions;

- To investigate the feasibility of an adsorption process such as activated carbon treatment in removing eNPs under controlled (synthetic water) and natural occurring conditions (surface water).

\subsection{Thesis organization and outline}

This dissertation research describes the removal behaviour of eNPs in drinking water treatment plants.

Chapter 2 investigates the removal mechanism of $\mathrm{nC}_{60}$ fullerene eNPs from dispersions in dead-end hollow fiber microfiltration and ultrafiltration . It elucidates the role of membrane pore size on the removal and removal mechanisms of $\mathrm{nC}_{60}$ fullerene eNPs. It focusses on eNPs filtration experiments performed under constant flux operating mode in dead-end membrane systems using commercially available hollow fiber membranes and including a backwash cleaning procedure with multiple cycles.

Chapter 3 extends the insight obtained of chapter 2 and investigates fullerene $\mathrm{nC}_{60}$ eNPs removal by microfiltration in real surface water. It focuses on the elucidation of the role of $\mathrm{NOM}$ and divalent cations on the removal of $\mathrm{nC}_{60}$ fullerene eNPs in semi dead-end hollow fiber microfiltration and on microfiltration membrane fouling during natural surface water filtration in the presence of fullerene $\mathrm{nC}_{60}$ eNPs. 


\section{Chapter 1}

Chapter 4 aims at scaling up laboratory experiments to pilot scale in order to validate the previously obtained removal efficiency results at lab-scale. It highlights essential aspects of the filtration behaviour of eNPs by microfiltration membranes at pilot-scale.

Chapter 5 investigates the removal of fullerene $\mathrm{nC}_{60}$ eNPs from water by coagulation with ferric chloride, a widely used coagulant in water and waste water treatment. It evaluates the influence of coagulant dosage and water chemistry parameters including NOM, the presence of divalent cations and the solution $\mathrm{pH}$ on the removal efficiency under both controlled conditions (a buffered ultra-pure water matrix) and natural occurring conditions (surface water and a pre-treated surface water matrix).

Chapter 6 investigates some of the aspects associated with the use of two different forms of activated carbon used in water treatment (powdered and granular activated carbon) in removing fullerene $\mathrm{nC}_{60} \mathrm{eNPs}$ from aqueous dispersions.

Chapter 7 summarizes the conclusions of this work and provides an outlook for further research. 


\section{References}

ASTM Standard E2456, 2012. Standard Terminology Relating to Nanotechnology. doi:10.1520/E2456-06R12

Auffan, M., Rose, J., Bottero, J.-Y., Lowry, G. V, Jolivet, J.-P., Wiesner, M.R., 2009. Towards a definition of inorganic nanoparticles from an environmental, health and safety perspective. Nat. Nanotechnol. 4, 634-41. doi:10.1038/nnano.2009.242

Baalousha, M., Stolpe, B., Lead, J.R., 2011. Flow field-flow fractionation for the analysis and characterization of natural colloids and manufactured nanoparticles in environmental systems: a critical review. J. Chromatogr. 1218, 4078-103. doi:10.1016/j.chroma.2011.04.063

Bakry, R., Vallant, R.M., Najam-ul-Haq, M., Rainer, M., Szabo, Z., Huck, C.W., Bonn, G.K., 2007. Medicinal applications of fullerenes. Int. J. Nanomedicine.

Behra, R., Krug, H., 2008. Nanoparticles at large. Nat. Nanotechnol. 3. doi:10.1021/es.7032718

Benn, T.M., Westerhoff, P., 2008. Nanoparticle silver released into water from commercially available sock fabrics. Environ. Sci. Technol. 42, 4133-9.

Brabec, C.J., Sariciftci, N.S., Hummelen, J.C., 2001. Plastic Solar Cells. Adv. Funct. Mater. 11, 15-26. doi:10.1002/1616-3028(200102)11:1<15::AID-ADFM15>3.0.CO;2-A

Chang, M.R., Lee, D.J., Lai, J.Y., 2007. Nanoparticles in wastewater from a science based industrial park Coagulation using polyaluminum chloride. J. Environ. Manage. 85, 10091014. doi:10.1016/j.jenvman.2006.11.013

Chen, K.L., Smith, B. a., Ball, W.P., Fairbrother, D.H., 2010. Assessing the colloidal properties of engineered nanoparticles in water: case studies from fullerene C 60 nanoparticles and carbon nanotubes. Environ. Chem. 7, 10. doi:10.1071/EN09112

Chen, K.L., Smith, B.A., Ball, W.P., Fairbrother, D.H., 2010. Assessing the colloidal properties of engineered nanoparticles in water: case studies from fullerene C60 nanoparticles and carbon nanotubes. Environ. Chem. 7, 10-27. doi:10.1071/EN09112

Chen, X., Mao, S.S., 2007. Titanium Dioxide Nanomaterials: Synthesis , Properties , Modifications, and Applications. Chem. Rev. 107. doi:10.1021/cr0500535

Chen, X., Schluesener, H.J., 2008. Nanosilver: A nanoproduct in medical application. Toxicol. Lett. 176, 1-12. doi:10.1016/j.toxlet.2007.10.004

Christian, P., Von Der Kammer, F., Baalousha, M., Hofmann, T., 2008. Nanoparticles: Structure, properties, preparation and behaviour in environmental media. Ecotoxicology 17, 326-343. doi:10.1007/s10646-008-0213-1

Crozes, G.F., Jacangelo, J.G., Anselme, C., La, J.M., 1997. Impact of ultrafiltration operating conditions on membrane irreversible fouling. J. Memb. Sci. 124, 63-76. 


\section{Chapter 1}

Duan, J., Gregory, J., 2003. Coagulation by hydrolysing metal salts. Adv. Colloid Interface Sci. 102, 475-502.

Edzwald, J.K., 2011. Water Quality and Treatment: A Handbook on Drinking Water, Sixth. ed. American Water Works Association, American Society of Civil Engineers, McGraw-Hill.

Feynman, R.P., 1960. There is plenty of room at the bottom. Eng. Sci. Mag. doi:10.1002/smll.200400080

Floris, R., Nijmeijer, K., Cornelissen, E.R., 2016. Removal of aqueous nC60 fullerene from water by low pressure membrane filtration. Water Res. 91, 115-125. doi:10.1016/j.watres.2015.10.014

Franks, A., 1987. Nanotechnology. J. Phys. E. 20, 1442-1451. doi:10.1088/0022$3735 / 20 / 12 / 001$

French, R., Jacobson, A., Kim, B., Isley, S., Penn, R.L., Baveye, P., 2009. Influence of ionic strength, $\mathrm{pH}$, and cation valence on aggregation kinetics of titanium dioxide nanoparticles. Environ. Sci. Technol. 43, 1354-9.

Ganesh, R., Smeraldi, J., Hosseini, T., Khatib, L., Olson, B.H., 2010. Evaluation of Nano Copper Removal and Toxicity in Municipal Wastewaters. Environ. Sci. Technol. 44, 7808 7813.

Garner, K.L., Keller, A.A., 2014. Emerging patterns for engineered nanomaterials in the environment: A review of fate and toxicity studies. J. Nanoparticle Res. 16. doi:10.1007/s11051-014-2503-2

Geranio, L., Heuberger, M., Nowack, B., 2009. The behavior of silver nanotextiles during washing. Environ. Sci. Technol. 43, 8113-8. doi:10.1021/es9018332

Gondikas, A.P., Von Der Kammer, F., Reed, R.B., Wagner, S., Ranville, J.F., Hofmann, T., 2014. Release of $\mathrm{TiO} 2$ nanoparticles from sunscreens into surface waters: A one-year survey at the old danube recreational lake. Environ. Sci. Technol. 48, 5415-5422. doi:10.1021/es405596y

Gottschalk, F., Nowack, B., 2011. The release of engineered nanomaterials to the environment. J. Environ. Monit. 13, 1145-55. doi:10.1039/c0em00547a

Grieger, K.D., Fjordb??ge, A., Hartmann, N.B., Eriksson, E., Bjerg, P.L., Baun, A., 2010. Environmental benefits and risks of zero-valent iron nanoparticles (nZVI) for in situ remediation: Risk mitigation or trade-off? J. Contam. Hydrol. 118, 165-183. doi:10.1016/j.jconhyd.2010.07.011

Grillo, R., Rosa, A.H., Fraceto, L.F., 2015. Engineered nanoparticles and organic matter : A review of the state-of-the-art. Chemosphere 119, 608-619. doi:10.1016/j.chemosphere.2014.07.049

Guldi, D., Prato, M., 2000. Excited-State Properties of C60 Fullerene Derivatives. Acc. Chem. Res. 33, 695-703. doi:10.1021/ar990144m

Guo, H., Wyart, Y., Perot, J., Nauleau, F., Moulin, P., Ce, P., 2010. Low-pressure membrane integrity tests for drinking water treatment: A review. Water Res. 44, 41-57. doi:10.1016/j.watres.2009.09.032 
He, M., Zhou, R., Guo, X., 2012. Behavior of stabilized multiwalled carbon nanotubes in a $\mathrm{FeCl} 3$ coagulation system and the structure characteristics of the produced flocs. J. Colloid Interface Sci. 366, 173-8. doi:10.1016/j.jcis.2011.09.059

Hendren, C.O., Mesnard, X., Dröge, J., Wiesner, M.R., 2011. Estimating production data for five engineered nanomaterials as a basis for exposure assessment. Environ. Sci. Technol. 45, 2562-9. doi:10.1021/es103300g

Henry, C., Brant, J. a., 2012. Mechanistic analysis of microfiltration membrane fouling by buckminsterfullerene (C60) nanoparticles. J. Memb. Sci. 415-416, 546-557. doi:10.1016/j.memsci.2012.05.042

Henry, C., Dorr, B., Brant, J. a., 2012. Buckminsterfullerene (C60) nanoparticle fouling of microfiltration membranes operated in a cross-flow configuration. Sep. Purif. Technol. 100, 30-43. doi:10.1016/j.seppur.2012.08.019

Hofmann, T., von der Kammer, F., 2009. Estimating the relevance of engineered carbonaceous nanoparticle facilitated transport of hydrophobic organic contaminants in porous media. Environ. Pollut. 157, 1117-26. doi:10.1016/j.envpol.2008.10.022

Holbrook, R.D., Kline, C.N., Filliben, J.J., 2010. Impact of source water quality on multiwall carbon nanotube coagulation. Environ. Sci. Technol. 44, 1386-91. doi:10.1021/es902946j

Howe, K.J., Marwah, A., Chiu, K.-P., Adham, S.S., 2007. Effect of membrane configuration on bench-scale MF and UF fouling experiments. Water Res. 41, 3842-9. doi:10.1016/j.watres.2007.05.025

Hyung, H., Kim, J.-H., 2009. Dispersion of C(60) in natural water and removal by conventional drinking water treatment processes. Water Res. 43, 2463-70. doi:10.1016/j.watres.2009.03.011

Jassby, D., Chae, S.-R., Hendren, Z., Wiesner, M., 2010. Membrane filtration of fullerene nanoparticle suspensions: effects of derivatization, pressure, electrolyte species and concentration. J. Colloid Interface Sci. 346, 296-302. doi:10.1016/j.jcis.2010.03.029

Jensen, A.W., Wilson, S.R., Schuster, D.I., 1996. Biological Applications of Fullerenes. Bioorg. Med. Chem. 4, 767-779.

Kaegi, R., Sinnet, B., Zuleeg, S., Hagendorfer, H., Mueller, E., Vonbank, R., Boller, M., Burkhardt, M., 2010. Release of silver nanoparticles from outdoor facades. Environ. Pollut. 158, 2900-5. doi:10.1016/j.envpol.2010.06.009

Kaegi, R., Ulrich, A., Sinnet, B., Vonbank, R., Wichser, A., Zuleeg, S., Simmler, H., Brunner, S., Vonmont, H., Burkhardt, M., Boller, M., 2008. Synthetic TiO2 nanoparticle emission from exterior facades into the aquatic environment. Environ. Pollut. 156, 233-9. doi:10.1016/j.envpol.2008.08.004

Keller, A.A., McFerran, S., Lazareva, A., Suh, S., 2013. Global life cycle releases of engineered nanomaterials. J. Nanoparticle Res. 15. doi:10.1007/s11051-013-1692-4

Kim, S., Marion, M., Jeong, B.-H., Hoek, E.M.V., 2006. Crossflow membrane filtration of interacting nanoparticle suspensions. J. Memb. Sci. 284, 361-372. doi:10.1016/j.memsci.2006.08.008 
Kirchner, C., Liedl, T., Kudera, S., Pellegrino, T., Gaub, H.E., Sto, S., Fertig, N., Parak, W.J., 2005. Cytotoxicity of Colloidal CdSe and CdSe / ZnS Nanoparticles. Nano Lett. 5, 331-338.

Kiser, M.A., Westerhoff, P., Benn, T., Wang, Y., Perez-Rivera, J., Hristovski, K., 2009. Titanium nanomaterial removal and release from wastewater treatment plants. Environ. Sci. Technol. 43, 6757-6763. doi:10.1021/es901102n

Klaine, S.J., Alvarez, P.J.J., Batley, G.E., Fernandes, T.F., Handy, R.D., Lyon, D.Y., Mahendra, S., McLaughlin, M.J., Lead, J.R., 2008. NANOMATERIALS IN THE ENVIRONMENT: BEHAVIOR, FATE, BIOAVAILABILITY, AND EFFECTS. Environ. Toxicol. 27, 1825-1851.

Kroto, H.W., Heath, J.R., O’Brien, S.C., Curl, R.F., Smalley, R.E., 1985. C60: Buckminsterfullerene. Nature 318, 162.

Ladner, D., Steele, M., Weir, A., Hristovski, K., Westerhoff, P., 2012. Functionalized nanoparticle interactions with polymeric membranes. J. Hazard. Mater. 211-212, 288-95. doi:10.1016/j.jhazmat.2011.11.051

Lead, J.R., Wilkinson, K.J., 2006. Aquatic Colloids and Nanoparticles : Current Knolvledge and Future Trends. Acquat. colloids nanoparticles 3, 159-171.

Liu, N., Liu, C., Zhang, J., Lin, D., 2012. Removal of dispersant-stabilized carbon nanotubes by regular coagulants. J. Environ. Sci. 24, 1364-1370. doi:10.1016/S1001-0742(11)60933-9

Lynch, I., Dawson, K.A., 2008. Protein-nanoparticle interactions. Nano Today 3, 40-47.

Mahmoudi, M., Serpooshan, V., 2011. Large Protein Absorptions from Small Changes on the Surface of Nanoparticles. hournal Phys. chamestry 115, 18275-18283.

Mueller, N.C., Nowack, B., 2008. Exposure modeling of engineered nanoparticles in the environment. Environ. Sci. Technol. 42, 4447-53.

Navarro, E., Baun, A., Behra, R., Hartmann, N.B., Filser, J., Miao, A.-J., Quigg, A., Santschi, P.H., Sigg, L., 2008. Environmental behavior and ecotoxicity of engineered nanoparticles to algae, plants, and fungi. Ecotoxicology 17, 372-86. doi:10.1007/s10646-008-0214-0

Nowack, B., Bucheli, T.D., 2007. Occurrence, behavior and effects of nanoparticles in the environment. Environ. Pollut. 150, 5-22. doi:10.1016/j.envpol.2007.06.006

Oberdörster, G., Oberdörster, E., Oberdörster, J., 2005. Nanotoxicology: An Emerging Discipline Evolving from Studies of Ultrafine Particles. Environ. Health Perspect. 113, 823839. doi:10.1289/ehp.7339

Pan, B., Xing, B., 2010a. Manufactured Nanoparticles and their Sorption of Organic Chemicals. Adv. Agron. 108, 137-181. doi:10.1016/S0065-2113(10)08003-X

Pan, B., Xing, B., 2010b. Chapter Three - Manufactured Nanoparticles and their Sorption of Organic Chemicals, in: Advances in Agronomy. pp. 137-181. doi:10.1016/S00652113(10)08003-X

Philippe, A., Schaumann, G.E., 2014. Interactions of Dissolved Organic Matter with Natural and Engineered Inorganic Colloids: A Review. Environ. Sci. Technol. 48, 8946-8962. 
Poland, C., Duffin, R., Kinloch, I., Maynard, A.D., Wallace, A.H.W., Seaton, A., Stone, V., Brown, S., Mac Nee, W., Donaldson, K., 2008. Carbon nanotubes introduced into the abdominal cavity of mice show asbestos-like pathogenicity in a pilot study. Nat. Nanotechnol. 3, 423-428. doi:10.1038/nnano.2008.111

Ray, P.C., Yu, H., Fu, P.P., 2009. Toxicity and environmental risks of nanomaterials: challenges and future needs. J. Environ. Sci. Health. C. Environ. Carcinog. Ecotoxicol. Rev. 27, 1-35. doi:10.1080/10590500802708267

Reisch, M.S., 2009. Innovation: Novel ingredients spread across incosmetics. Chem. Eng. News.

Rezić, I., 2011. Determination of engineered nanoparticles on textiles and in textile wastewaters. TrAC Trends Anal. Chem. 30, 1159-1167. doi:10.1016/j.trac.2011.02.017

Sánchez, A., Recillas, S., Font, X., Casals, E., González, E., Puntes, V., 2011. Ecotoxicity of, and remediation with, engineered inorganic nanoparticles in the environment. Trends Anal. Chem. 30, 507-516. doi:10.1016/j.trac.2010.11.011

Sayes, C.M., Gobin, A.M., Ausman, K.D., Mendez, J., West, J.L., Colvin, V.L., 2005. NanoC60 cytotoxicity is due to lipid peroxidation. Biomaterials 26, 7587-95. doi:10.1016/j.biomaterials.2005.05.027

Schafer, A.I., 2000. Microfiltration of colloids and natural organic matter. J. Memb. Sci. 171, 151-172.

Scown, T.M., van Aerle, R., Tyler, C.R., 2010. Review: Do engineered nanoparticles pose a significant threat to the aquatic environment? Crit. Rev. Toxicol. 40, 653-70. doi:10.3109/10408444.2010.494174

Sharifi, S., Behzadi, S., Laurent, S., Ml, F., Stroeve, P., Mahmoudi, M., 2012. Toxicity of nanomaterials. Chem. Soc. Rev. 41 VN - r, 2323-2343. doi:10.1039/c1cs15188f

Sillanpää, M., 2015. Natural Organic Matter in Water, Natural Organic Matter in Water. Elsevier. doi:10.1016/B978-0-12-801503-2.00001-X

Som, C., Berges, M., Chaudhry, Q., Dusinska, M., Fernandes, T.F., Olsen, S.I., Nowack, B., 2010. The importance of life cycle concepts for the development of safe nanoproducts. Toxicology 269, 160-9. doi:10.1016/j.tox.2009.12.012

Srivastava, V., Gusain, D., Sharma, Y.C., 2015. Critical Review on the Toxicity of Some Widely Used Engineered Nanoparticles. Ind. Eng. Chem. Res. 54, 6209-6233. doi:10.1021/acs.iecr.5b01610

Stefaniuk, M., Oleszczuk, P., Ok, Y.S., 2016. Review on nano zerovalent iron (nZVI): From synthesis to environmental applications. Chem. Eng. J. 287, 618-632. doi:10.1016/j.cej.2015.11.046

Stone, V., Nowack, B., Baun, A., van den Brink, N., Kammer, F. Von Der, Dusinska, M., Handy, R., Hankin, S., Hassellöv, M., Joner, E., Fernandes, T.F., 2010. Nanomaterials for environmental studies: classification, reference material issues, and strategies for physicochemical characterisation. Sci. Total Environ. 408, 1745-54. doi:10.1016/j.scitotenv.2009.10.035 
Sun, Q., Li, Y., Tang, T., Yuan, Z., Yu, C.-P., 2013. Removal of silver nanoparticles by coagulation processes. J. Hazard. Mater. 261, 414-20. doi:10.1016/j.jhazmat.2013.07.066

Tarabara, V.V., Hovinga, R.M., Wiesner, M.R., 2002. Constant transmembrane pressure vs. constant permeate flux: Effect of particle size on crossflow membrane filtration. Environ. Eng. Sci. 19, 343-355.

Theis, T., Parr, D., Binks, P., Ying, J., Drexler, K.E., Schepers, E., Mullis, K., Bai, C., Boland, J.J., Langer, R., Dobson, P., Rao, C.N.R., Ferrari, M., 2006. Nan'O.Tech.Nol'O.Gy N. Nat. Nanotechnol. 1, 8-10. doi:10.1038/nnano.2006.77

Tiede, K., Boxall, A.B. a, Tear, S.P., Lewis, J., David, H., Hassellov, M., 2008. Detection and characterization of engineered nanoparticles in food and the environment. Food Addit. Contam. 25, 795-821. doi:10.1080/02652030802007553

Tolaymat, T.M., El Badawy, A.M., Genaidy, A., Scheckel, K.G., Luxton, T.P., Suidan, M., 2010. An evidence-based environmental perspective of manufactured silver nanoparticle in syntheses and applications: A systematic review and critical appraisal of peer-reviewed scientific papers. Sci. Total Environ. 408, 999-1006. doi:10.1016/j.scitotenv.2009.11.003

Vance, M.E., Kuiken, T., Vejerano, E.P., McGinnis, S.P., Hochella, M.F., Rejeski, D., Hull, M.S., 2015. Nanotechnology in the real world: Redeveloping the nanomaterial consumer products inventory. Beilstein J. Nanotechnol. 6, 1769-1780. doi:10.3762/bjnano.6.181

Wang, C., Dai, J., Shang, C., Chen, G., 2013a. Removal of aqueous fullerene nC60 from wastewater by alum-enhanced primary treatment. Sep. Purif. Technol. 116, 61-66. doi:10.1016/j.seppur.2013.05.035

Wang, C., Shang, C., Chen, G., Zhu, X., 2013b. Mechanisms of nC60 removal by the alum coagulation-flocculation-sedimentation process. J. Colloid Interface Sci. 411, 213-9. doi:10.1016/j.jcis.2013.08.023

Wang, H., Qi, J., Keller, A.A., Zhu, M., Li, F., 2014. Effects of pH , ionic strength and humic acid on the removal of TiO 2 nanoparticles from aqueous phase by coagulation. Colloids Surfaces A Physicochem. Eng. Asp. 450, 161-165. doi:10.1016/j.colsurfa.2014.03.029

Wang, H., Ye, Y., Qi, J., Li, F., Tang, Y., 2013. Removal of titanium dioxide nanoparticles by coagulation: effects of coagulants, typical ions, alkalinity and natural organic matters. Water Sci. Technol. 68, 1137-1143. doi:10.2166/wst.2013.356

Wang, P., Lim, T.T., 2012. Membrane vis-LED photoreactor for simultaneous penicillin G degradation and TiO 2 separation. Water Res. 46, 1825-1837. doi:10.1016/j.watres.2011.12.057

Westerhoff, P., Song, G., Hristovski, K., Kiser, M.A., 2011. Occurrence and removal of titanium at full scale wastewater treatment plants: implications for $\mathrm{TiO} 2$ nanomaterials. $\mathrm{J}$. Environ. Monit. 13, 1195. doi:10.1039/c1em10017c

Wu, N., Wyart, Y., Liu, Y., Rose, J., Moulin, P., 2013. An overview of solid/liquid separation methods and size fractionation techniques for engineered nanomaterials in aquatic environment. Environ. Technol. Rev. 2, 55-70. doi:10.1080/09593330.2013.788073 
Zhang, L., Zhao, Q., Wang, S., Mashayekhi, H., Li, X., Xing, B., 2014. Influence of ions on the coagulation and removal of fullerene in aqueous phase. Sci. Total Environ. 466-467, 604 8. doi:10.1016/j.scitotenv.2013.07.077

Zhang, Y., Chen, Y., Westerhoff, P., Crittenden, J.C., 2008. Stability and Removal of Water Soluble CdTe Quantum Dots in Water. Environ. Sci. Technol. 42, 321-325.

Zhang, Y., Chen, Y., Westerhoff, P., Hristovski, K., Crittenden, J.C., 2008. Stability of commercial metal oxide nanoparticles in water. Water Res. 42, 2204-12. doi:10.1016/j.watres.2007.11.036 


\section{Removal of AQUEOUS $\mathrm{nC}_{60}$ FULLERENE FROM WATER}

\section{BY LOW PRESSURE MEMBRANE}

FILTRATION

This chapter has been published as:

Floris, R., Nijmeijer, K., Cornelissen, E.R., 2016

Removal of aqueous $\mathrm{nC}_{60}$ fullerene from water by low pressure membrane filtration. Water Research, 91, 115-125 (2016)

doi:10.1016/j.watres.2015.10.014 


\begin{abstract}
The potential environmental and health risks of engineered nanoparticles such as buckminsterfullerene $\mathrm{C}_{60}$ in water require their removal during the production of drinking water. We present a study focusing on (i) the removal mechanism and (ii) the elucidation of the role of the membrane pore size during removal of $\mathrm{nC}_{60}$ fullerene nanoparticle dispersions in dead-end microfiltration and ultrafiltration mimicking separation in real industrial water treatment plants. Membranes were selected with pore sizes ranging from $18 \mathrm{~nm}$ to $500 \mathrm{~nm}$ to determine the significance of the $\mathrm{nC}_{60}$ to membrane pore size ratio and the adsorption affinity between $\mathrm{nC}_{60}$ and membrane material during filtration. Experiments were carried out with a dead-end bench-scale system operated at constant flux conditions including a hydraulic backwash cleaning procedure. $\mathrm{nC}_{60}$ nanoparticles can be efficiently removed by low pressure membrane technology with smaller and, unexpectedly, also by mostly similar or larger pores than the particle size, although the $\mathrm{nC}_{60}$ filtration behaviour appeared to be different. The $\mathrm{nC}_{60}$ size to membrane pore size ratio and the ratio of the cake-layer deposition resistance to the clean membrane resistance, both play an important role on the $\mathrm{nC}_{60}$ filtration behaviour and on the efficiency of the backwash procedure recovering the initial membrane filtration conditions. These results become specifically significant in the context of drinking water production, for which they provide relevant information for an accurate selection between membrane processes and operational parameters for the removal of $\mathrm{nC}_{60}$ in the drinking water treatment.
\end{abstract}




\section{Chapter 2}

\subsection{Introduction}

The increasing use of engineered nanoparticles (eNPs) in consumer products like food, paints, coatings, cosmetics, personal care products, etc. (Benn et al., 2011; Murayama et al., 2004; Osawa, 2002) will lead to direct and indirect release of eNPs to the environment and to sources for drinking water. Specifically Buckminsterfullerene $\left(\mathrm{C}_{60}\right)$ (Kroto et al., 1985) has received a considerable amount of attention due to its particular chemical physical properties (Guldi and Prato, 2000) i.e. high hydrophobicity, heat resistance and superconductivity, which explains its wide spread use in different applications (Baena et al., 2002; Osawa, 2002). Although non derivatized $\mathrm{C}_{60}$ nanoparticles have a very low solubility in water (Heymann, 1996) and are highly hydrophobic $\left(\mathrm{K}_{\mathrm{ow}}=6.67\right.$ (Jafvert and Kulkarni, 2008)) $\mathrm{C}_{60}$ can form nano-sized colloidal aggregates in water (usually and here as well referred to as $\mathrm{nC}_{60}$ ) (Deguchi et al., 2001) and could therefore end up in aquatic environments when released to the environment. Several studies reported $\mathrm{C}_{60}$ toxicity to various organisms (Chae et al., 2009; Lyon et al., 2006; Sayes et al., 2005; Song et al., 2012). These results are still under debate because it is not completely clear if the toxicity reported is related to the $\mathrm{C}_{60}$ itself or that the preparation method of $n \mathrm{C}_{60}$ colloidal dispersions as well influences the toxicological results (Zhu et al., 2006). However, due to this possible toxicological nature, the removal of $\mathrm{nC}_{60}$ from water becomes mandatory to ensure the production of safe drinking water and to minimize human exposure to eNPs via ingestion. Moreover, eNPs can serve as pollutant carriers (Hofmann and von der Kammer, 2009; Navarro et al., 2008; Stone et al., 2010) potentially resulting into inadequacy of existing treatment processes. These uncertainties on $\mathrm{nC}_{60}$ toxicity and the $\mathrm{nC}_{60}$ potentiality as pathogens carrier result in a mandatory removal of $\mathrm{nC}_{60}$ in water treatment plants. Low pressure membranes are a viable solution in removing contaminants that are similar in size to eNPs such as viruses, proctozoa cysts (H Guo et al., 2010) and colloids (Schafer, 2000). Thus it is expected that eNPs can be effectevely removed by low pressure membrane filtration as well. However so far, detailed studies on the effectiveness of the filtration for eNPs, their filtration behavior and their exact removal mechanism are lacking.

Some studies focused on a single specific aspect related to interactions between eNPs and low pressure membranes have been carried out in different fields of membrane research, such 
as eNP characterization (Baalousha et al., 2011), eNP size separation (Akamatsu et al., 2010; Xie et al., 2009) and membrane integrity tests (H. Guo et al., 2010), but to the best of our knowledge only very few studies dealt with the understanding of the removal mechanism of eNPs by membrane filtration techniques. Destabilized fullerene sispersions $\left(\mathrm{nC}_{60}\right.$ and fullerol) were filtered through $20 \mathrm{~nm}$ ceramic membranes under variable ionic strength, ionic composition and pressure gradients (Jassby et al., 2010). The removal efficiency was below $80 \%$ at a transmembrane pressure of $20 \mathrm{kPa}$. The separation of fullerenes from the aqueous sispersion increased, or decreased, depending on the solution $\mathrm{pH}$ and ionic strength, while transmembrane pressure only affected the retention of fullerol. The interactions between a set of functionalized eNPs and polymeric membranes composed of different materials and pore sizes (ranging from $2 \mathrm{~nm}$ to $200 \mathrm{~nm}$ ) were investigated as well (Ladner et al., 2011). The authors observed in general (i) a dependency of the particle size to membrane pore size ratio on the removal efficiency and (ii) that removal mechanisms were influenced by the surface affinity between eNPs and membranes, facilitating also the removal of eNPs smaller in size than the membrane pores. They also concluded that the eNP properties appeared to be more important in determining the transport behavior than the membrane properties. Although the aforementioned studies provided valuable knowledge on the interactions between eNPs and low pressure membranes, the results are difficult to translate to real water treatment plants because none of the reported studies (i) was performed under typical fullscale conditions such as a constant flux operating mode in dead-end membrane systems and (ii) used a hollow fiber membrane configuration typically used in water treatment plants (Crozes et al., 1997; Howe et al., 2007; Tarabara et al., 2002). To bridge this gap the focus of the present study is on (i) the removal mechanism of $\mathrm{nC}_{60}$ fullerene eNPs from sispersions in dead-end hollow fiber microfiltration and ultrafiltration and (ii) the elucidation of the role of membrane pore size on the removal and removal mechanisms of $\mathrm{nC}_{60}$ fullerene. To the best of our knowledge this work is the first one reporting nanoparticle filtration experiments performed under constant flux operating mode in dead-end membrane systems using commercially available hollow fiber membranes and including a backwash cleaning procedure with multiple cycles. Removal and removal mechanisms were evaluated by analysing transmembrane pressure (TMP) changes during filtration, measuring permeability recovery and performing membrane autopsy by visual and electron microscopy observation of the deposition of $\mathrm{nC}_{60}$ on the inner membrane surface. 


\subsection{Theory}

Based on previous studies (Jassby et al., 2010; Ladner et al., 2011), particle size distribution is expected to play an important role in determining the removal efficiency and removal mechanism by low pressure membrane filtration. A high removal of eNPs by tight membranes (pore size smaller than nanoparticle diameter) is expected and size exclusion is expected to be the dominant separation mechanism, whereas for the more open membranes (pore size larger than nanoparticle diameter) a lower removal is expected, where removal is predominantly due to a combination of adsorption onto the membrane material and pore entrapment in the internal membrane structure. Removal can also occur when the membrane pore size is much larger than the nanoparticle diameter (Ladner et al., 2011) if membrane and eNPs have an adsorption affinity (Figure 2-1c).
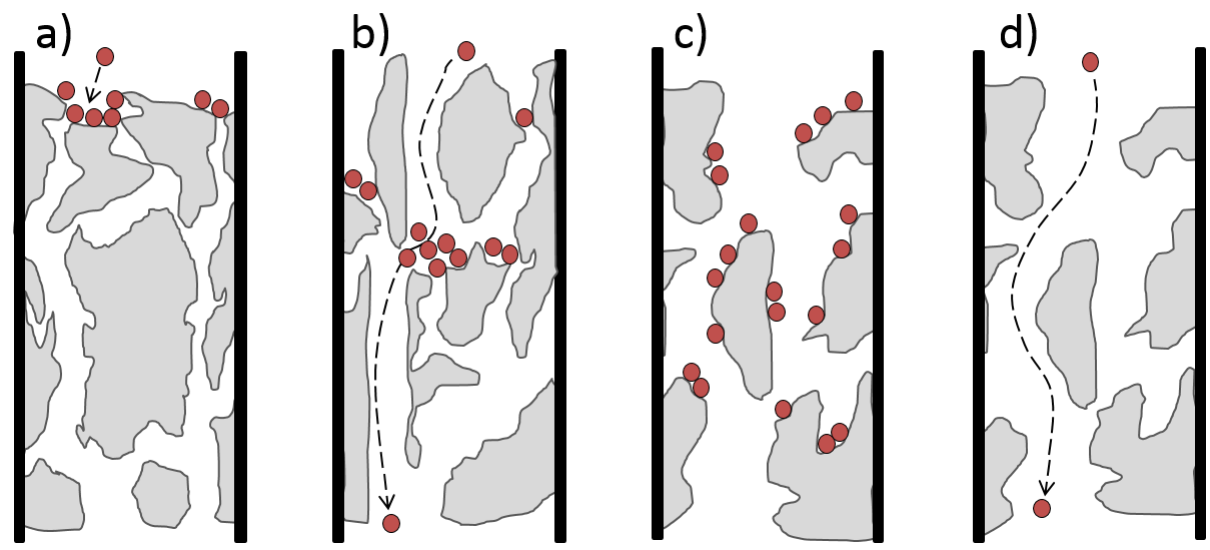

Figure 2-1: Different $n C_{60}$ removal mechanisms expected for low pressure membranes: a) Pore size smaller than $n C_{60}$ size resulting in high removal efficiency and surface layer deposition combined with pore blocking; b) Pore size larger/comparable than $n_{60}$ size resulting in partial removal and internal membrane deposition (pore entrapment and pore narrowing); c) Pore size larger than $n_{60}$ size and adsorption affinity resulting in partial removal of eNPs; d) Pore size larger than ${ }^{n} C_{60}$ size without adsorption affinity resulting in eNPs breakthrough (adapted from (Ladner et al., 2011)).

Retention can occur (a) by deposition onto the membrane surface resulting in external deposition (cake layer formation) and pore blocking (Figure 2-1a: the pore size is smaller than the eNPs diameter), (b) by deposition into the membrane internal structure resulting in 
pore entrapment and pore narrowing (Figure 2-1b: the pore size is larger than/comparable to the nanoparticle diameter) and (c) by adsorption onto the internal and external membrane surface due to nanoparticle and membrane adsorption affinity (Figure 2-1c). Retention cannot occur if the membrane pore size is larger than the eNPs diameter and there is no adsorption affinity between eNPs and the membrane material (Figure 2-1d).

Some eNPs accumulated on the membrane surface or in the membrane structure may be removed by physical (or chemical) cleaning but some fouling, more likely fouling that deposit in the membrane structure might be irreversible (Fane et al., 2006). eNPs that deposit within the membrane pore structure are likely to be subjected to less substantial hydraulic shear forces, and may therefore not be effectively removed through physical actions like backwashing (Henry et al., 2012). Therefore we assume that a deposited cake-layer (Figure 1a) can be removed by a hydraulic backwash sequence recovering the initial membrane permeability (Li et al., 2010; Mulder, 1991), while pore blockage, pore constriction and adsorption (Figure 2-1b, c) will result in $\mathrm{nC}_{60}$ accumulation in the membrane structure in time resulting in an increase of the transmembrane pressure in time (Crozes et al., 1993; Huang et al., 2007; Singh, 2015).

The resistance in series model can be applied to identify differences in the particle deposition/removal mechanisms (Cho et al., 1999; Hong and Elimelech, 1997; Mulder, 1991). The flux in porous media can be described by Darcy's Law (Equation 4):

$$
\mathrm{J}=\frac{\mathrm{TMP}}{v \cdot \mathrm{R}_{\text {tot }}}
$$

Where $\mathrm{J}$ is the water flux $\left[\mathrm{L} / \mathrm{m}^{2} \cdot \mathrm{h}\right]$, TMP is the transmembrane pressure [bar], $v$ is the dynamic viscosity of the feed solution $[\mathrm{Pa} \cdot \mathrm{s}]$, and $\mathrm{R}_{\mathrm{T}}$ is the total hydraulic membrane resistance $[1 / \mathrm{m}] . \mathrm{R}_{\mathrm{T}}$ can also be written as:

$$
R_{T}=R_{M}+R_{E}+R_{l}
$$

Where $R_{M}$ is the hydraulic resistance of the clean membrane, $R_{E}$ is the resistance due to the external cake-layer deposition (Figure 2-1a) and $\mathrm{R}_{\mathrm{I}}$ is the resistance due to internal pore blockage and pore constriction (Figure 2-1b, c). All resistances are expressed in $1 / \mathrm{m}$ and can be obtained from the experimental data of a series of filtration and backwash cycles. 


\section{Chapter 2}

Rearrangement of Equation 1 after substitution of Equation 2 in Equation 1 yields Equation 3:

$$
\mathrm{R}_{\mathrm{T}}=\frac{\mathrm{TMP}}{v \cdot \mathrm{J}}
$$

During filtration of ultrapure water through a virgin membrane, internal and external deposition of eNPs does not occur. Therefore, $R_{E}=R_{I}=0$ and only $R_{M}$ contributes to the total hydraulic resistance, which can thus be calculated as follows:

$$
\mathrm{R}_{\mathrm{M}}=\left.\frac{\mathrm{TMP}}{v \cdot \mathrm{J}}\right|_{\mathrm{vergin}}
$$

$\mathrm{R}_{\mathrm{T}}$ is obtained from the $\mathrm{nC}_{60}$ filtration experiments considering the TMP at the end of the filtration cycle after both external and internal deposition:

$$
\mathrm{R}_{\mathrm{T}}=\left.\frac{\mathrm{TMP}}{v \cdot \mathrm{J}}\right|_{\text {fouled }}
$$

Experimental data on ultrapure water permeation through a fouled and backwashed membrane (assuming that external deposition is completely removed by hydraulic shear forces) allows the calculation of the remaining resistance:

$$
\mathrm{R}_{\mathrm{l}}=\left.\frac{\mathrm{TMP}}{v \cdot \mathrm{J}}\right|_{\text {backwashed }}
$$

Finally, $\mathrm{R}_{\mathrm{E}}$ can be obtained by rearranging Equation 2:

$$
R_{E}=R_{T}-R_{M}-R_{1}
$$




\subsection{Material and Methods}

\subsubsection{Reagents and Chemicals}

Fullurene- $\mathrm{C}_{60}$ (purity >99.5\%) was obtained from Sigma Aldrich (Steinheim, Germany). Toluene was purchased from Mallinckrodt Baker B.V. (Deventer, the Netherlands). Ultrapure water $(18.2 \mathrm{~m} \Omega \cdot \mathrm{cm})$ was obtained by purifying demineralized water in a Milli-Q system (Millipore, Bedford, MA).

\subsubsection{Preparation of aqueous fullerene dispersions}

Stable aqueous $\mathrm{nC}_{60}$ nanoparticle dispersions were prepared using a solvent exchange/sonication procedure (Chen and Elimelech, 2007). Briefly, $50 \mathrm{mg}$ of $\mathrm{C}_{60}$ fullerene powder was added to $100 \mathrm{~mL}$ toluene and was stirred for at least $12 \mathrm{~h}$ to achieve complete dissolution of the fullerenes. The $\mathrm{C}_{60}$ solution was added to $350 \mathrm{~mL}$ ultrapure water in a 600 $\mathrm{mL}$ beaker. Toluene was evaporated in a sonication bath (Branson) at an energy intensity of $125 \mathrm{~W}$. Ultrapure water was regularly added each hour to compensate the volume loss due to toluene evaporation and to avoid fullerene deposition. The resulting colloidal dispersion was finally filtered through a 0.45 and $0.22 \mu \mathrm{m}$ cellulose acetate vacuum filter system (Corning Amsterdam, the Netherlands) resulting in a $\mathrm{nC}_{60}$ stock solution concentration of $15-20 \mathrm{mg} / \mathrm{L}$. Prior to the filtration experiments the obtained stock solution was diluted in ultrapure water to obtain a membrane feed solution of $1.03 \pm 0.17 \mathrm{mg} / \mathrm{L}$.

\subsubsection{Characterization of aqueous fullerene dispersion size}

Characterization of the $\mathrm{nC}_{60}$ feed dispersion, permeate and backwash samples, was performed with a set of different analytical techniques. The formation of the colloidal dispersions was corroborated by a UV-VIS spectrophotometer. Concentrations of $\mathrm{nC}_{60}$ dispersions were measured after liquid-liquid extraction by liquid chromatography coupled to high-resolution mass spectrometry and UV spectrophotometry (LC-MS-UV) (Kolkman et al., 2013). The size distribution was determined by dynamic light scattering (DLS), 


\section{Chapter 2}

nanoparticle tracking analysis (NTA) and analytical ultra-centrifugation (AUC). DLS measurements were performed with a Zetasizer Nano-ZS (Malvern Instruments, Worcestershire, UK). Samples were measured at $25{ }^{\circ} \mathrm{C}$, in triplicate, and each measurement was the average of at least 15 runs. NTA measurements were performed with a NanoSight LM10 (NanoSight, Amesbury, UK). Samples were diluted in order to reach the recommended measurement concentration of about $10^{8}$ particles/mL (Filipe et al., 2010)

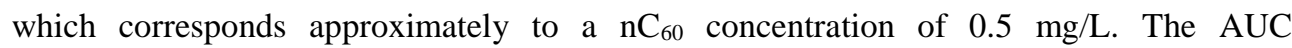
measurements to determine the $\mathrm{nC}_{60}$ size distributions were made using a disc centrifuge (CPS Instruments Inc., USA). Measurements were made at a disc rotation speed of 20000 rpm and particle sedimentation was carried out at an 8-24 wt \% sucrose density gradient.

Prior to each sample measurement the instrument was calibrated using PVC nanosphere standards $(476 \mathrm{~nm})$. Electrophoretic mobility measurements were used to evaluate the surface charge and zeta potential determined with a Zetasizer Nano-ZS (samples measured 6 times per measuring point).

\subsubsection{Membrane and membrane characterization}

To understand the role of membrane pore size on the membrane removal and removal mechanism, three low-pressure membranes differing in pore size were selected. Two microfiltration membranes (200 $\mathrm{nm}$ and $500 \mathrm{~nm}$ pore size) and one ultrafiltration membrane (18 nm pore size and $150 \mathrm{kDa}$ MWCO) were supplied by Pentair X-Flow (Enschede, the Netherlands). These were all commercially available hollow fiber polymeric polyethersulfone membranes containing polyvinylpyrrolidone that were operated inside-out. The commercial names of the membranes are reported in Table 2-1. Lab-scale membrane modules were prepared by potting membrane fibers with a two-component epoxy resin (Polipox, Poli-service, Amsterdam, the Netherlands) in a transparent plastic tube (poly vinyl chloride) of $23 \mathrm{~cm}$ length and $1 \mathrm{~cm}$ diameter to obtain a membrane filtration area of $10 \mathrm{~cm}^{2}$. The housing is equipped with a feed inlet connection (is also the backwash outlet connection), a permeate outlet connection (is also the backwash inlet connection) and two manually adjustable valves to release air bubbles that might form inside the fibers and/or the housing. 
In this study membranes were characterized with respect to pore size, inner surface charge and pure water permeability. The pore size and pore size distribution of the membranes was measured with a Porolux 1000 capillary flow porometer (Porometer NV). Wetting fluid was used to wet the membrane prior to the measurements, which were carried out in duplicate. The mean pore diameter was calculated from the mean flow pressure, which corresponds to the intersection of the wet curve with the calculated half-dry curve (calculated from a dry and a wet run (Agarwal et al., 2012; Li et al., 2006)). The zeta potential of the inner surface of the membranes was measured using a SurPASS electrokinetic analyzer (Anton Paar GmbH). Measurements were carried out with $5 \mathrm{mM} \mathrm{KCl}$ as a background electrolyte solution. The $\mathrm{pH}$ was adjusted to values between 3 and 9.5 using aqueous $0.1 \mathrm{M} \mathrm{NaOH}$ and $0.1 \mathrm{M} \mathrm{HCl}$ solutions. The zeta potential was calculated according to the Fairbrother-Mastin equation (Ariza and Benavente, 2001). The membrane characteristics and module geometries are summarized in Table 2-1.

Table 2-1: Membrane and module characteristics.

\begin{tabular}{llll}
\hline Commercial name & UFC M5 & MF02 M2 & MF05 M2 \\
\hline Membrane process & Ultrafiltration & Microfiltration & Microfiltration \\
Pore size* [nm] & 18 & 200 & 500 \\
Average pore size measured [nm] & 15 & 186.6 & 745.6 \\
Smallest pore size measured [nm] & $-* *$ & 180.6 & 578 \\
Filtration area [cm $\left.{ }^{2}\right]$ & 10 & 10 & 10 \\
Fibers/module [-] & 2 & 1 & 1 \\
Inner fiber diameter [mm] & 0.8 & 1.5 & 1.5 \\
Volume/Area ratio [mm] & 0.2 & 0.4 & 0.4 \\
Zeta potential $* * *[\mathbf{m V}]$ & $-29.7 \pm 4.5$ & $-19.8 \pm 5.1$ & $-18.9 \pm 7.7$ \\
\hline
\end{tabular}

* provided by manufacturer; ** not measured; *** measured at $\mathrm{pH} 6.5$ 


\subsubsection{Membrane filtration apparatus and filtration procedure}

Pure water flux and $\mathrm{nC}_{60}$ filtration measurements were performed with a lab-scale pilot (Fig. 2-2).

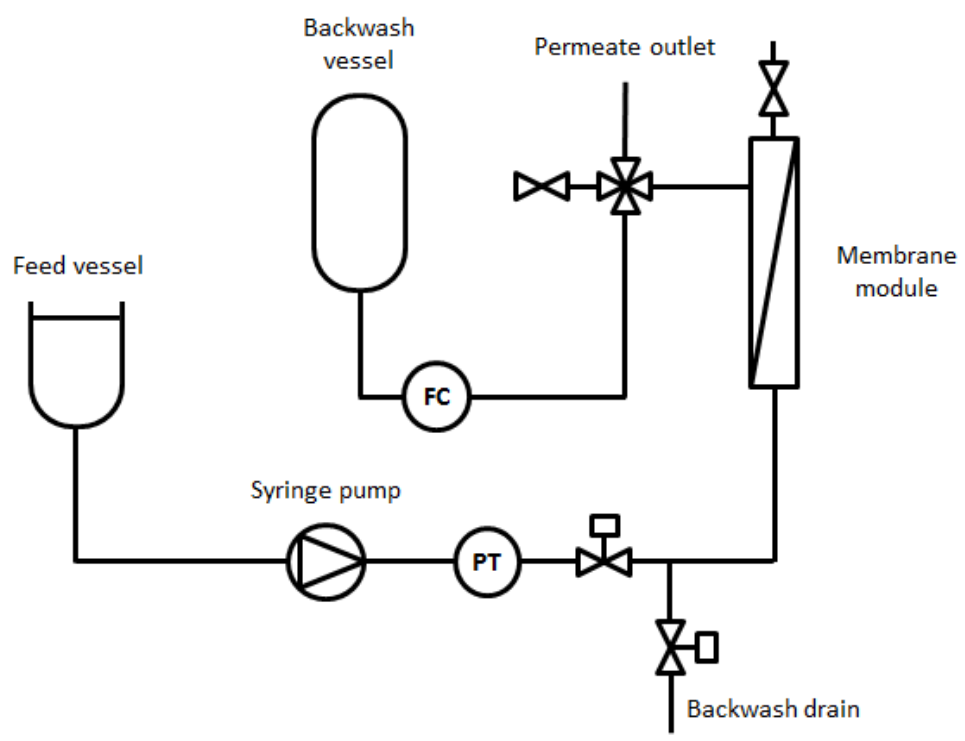

Figure 2-2: Schematic representation of the lab-scale installation for constant flux filtration experiments.

A constant feed flow of $0.5 \mathrm{~L} / \mathrm{h}$ was provided by a pulsation free neMESYS syringe pump (Cetoni GmbH, Germany) connected to the feed vessel. A pressure sensor in the feed line measured the transmembrane pressure (TMP) in front of the membrane every 5 seconds and an average TMP out of 3 measurements was logged every 15 seconds. A pressurized vessel (3 bars) containing fresh ultra-pure water combined with a flow controller was connected to a permeate line for the backwash sequence. A 20 seconds backwash occurred automatically every $20 \mathrm{~min}$. The filtration measurement duration was 2 hours resulting in a series of 6 filtration cycles and 6 backwash sequences. All these experiments were performed at a constant temperature of $20{ }^{\circ} \mathrm{C}$. Feed and cumulative permeate samples were collected and analysed for rejection calculations. MF05 permeate samples were collected during filtration cycle number one, two, four and six to evaluate nanoparticle removal and nanoparticle size distribution at different filtration stages. After the last backwash procedure, the membrane 
was flushed with ultra-pure water to evaluate the membrane permeability after nanoparticle filtration, from which the pure water permeability recovery was calculated, which is an indirect indication of the particles remaining on the membrane after the cleaning procedure.

\subsubsection{Data handling}

We evaluated the removal efficiency $\left(\mathrm{R}[\%]\right.$ ) of $\mathrm{nC}_{60}$ dispersions as the $\mathrm{nC}_{60}$ rejection calculated from Equation 9:

$R=\left(1-\frac{C_{p}}{C_{f}}\right) \times 100$

Where $C_{p}$ is the permeate concentration and $C_{f}$ is the feed concentration $[\mathrm{mg} / \mathrm{L}]$.

To assess the removal mechanism of $\mathrm{nC}_{60}$ by the low-pressure membranes, we analysed the evolution of measurable process parameters in time. The membrane permeability $\mathrm{k}[\mathrm{m} / \mathrm{Pa} \cdot \mathrm{s}]$ is defined as the reciprocal of the filtration resistance and can be calculated by Equation 10:

$$
\mathrm{k}=\frac{\mathrm{J}}{\mathrm{TMP}} v
$$

Where $\mathbf{J}$ is the water flux $\left[\mathrm{L} / \mathrm{m}^{2} \cdot \mathrm{h}\right]$ and TMP is the transmembrane pressure [bar] and $v$ is the dynamic viscosity of the feed solution $[\mathrm{Pa} \cdot \mathrm{s}]$.

The subsequent permeability recovery is given by Equation 11:

$\mathrm{k}_{\mathrm{R}}=\frac{\mathrm{k}_{\text {After backwash }}}{\mathrm{k}_{\text {Before filtration }}} \times 100$

Application of pore blocking law for constant flux filtration

To clarify the removal mechanism occurring during UF18 and MF02 filtration blocking laws for constant flux low pressure membrane filtration were applied (Huang et al., 2008). Depending on the pore blocking mechanism the TMP increase during filtration can be described by 
$\frac{\mathrm{dTMP}}{\mathrm{dV_{ \textrm {s } }}}=\mathrm{k}_{\mathrm{v}}(\mathrm{TMP})^{\mathrm{n}}$

Where Vs $\left(\mathrm{m}^{3} / \mathrm{m}^{2}\right.$ or $\left.\mathrm{L} / \mathrm{m}^{2}\right)$ is the permeate, throughput defined as the cumulative volume of permeate per unit of membrane area and $\mathrm{k}_{\mathrm{v}}$ and $\mathrm{n}$ are 2 experimental parameters where $\mathrm{n}$ is a dimensionless number that is related to the pore blocking mechanism and $\mathrm{k}_{\mathrm{v}}$ is related to the blocking mechanism and to the foulant concentration in the filtered water. The model has been applied here in the linearized form proposed by Huang e $t$ al. (2008). The expressions and the coefficient are reported in Table 2-2 (Huang et al., 2008). For a more detailed explanation of the derivation we refer to the original publication (Huang et al., 2008).

Table 2-2 Linear expressions of blocking laws for low pressure membrane filtration.

\begin{tabular}{lccc}
\hline Fouling mechanism & $\boldsymbol{n}$ & $\boldsymbol{k v}$ & \multicolumn{1}{c}{ Linear expression } \\
\hline Cake formation & 0 & $C_{f} \frac{\hat{R}_{c}}{R_{m}}$ & $J_{s}^{\prime}=\left(1+k_{v} V_{s}\right)^{-1}$ \\
Intermediate blocking & 1 & $C_{f} \sigma$ & $J_{s}^{\prime}=e^{-k_{v} V_{s}}$ \\
Standard blocking & $3 / 2$ & $2 \frac{C_{f}}{L \rho}$ & $J_{s}^{\prime}=\left(1+\frac{k_{v}}{2 V_{s}}\right)$ \\
Complete blocking & 2 & $C_{f} \sigma$ & $J_{s}^{\prime}=\left(1-k_{v} V_{s}\right)$ \\
\hline
\end{tabular}

Where $J_{S}^{\prime}$ is the normalized (in respect to the clean water flux) specific flux (-), $\mathrm{C}_{\mathrm{f}}$ is the mass concentration of foulants in the source water, $\mathrm{kg} / \mathrm{m}^{3}, \hat{R}_{c}$ is the specific cake resistance $(\mathrm{m} / \mathrm{kg})$, $R_{m}$ is the membrane resistance $(1 / \mathrm{m})$, $\sigma$ is the projected area of a unit mass of the particles on membrane $\left(\mathrm{m}^{2} / \mathrm{kg}\right), \mathrm{L}$ is the effective membrane pore length $(\mathrm{m})$ and $\rho$ is the density of foulants $\left(\mathrm{kg} / \mathrm{m}^{3}\right)$. 


\subsection{Results and discussion}

\subsubsection{Characterization of $\mathrm{nC}_{60}$ dispersions}

The $\mathrm{nC}_{60}$ UV/VIS absorption spectrum of the feed solution displayed two typical peaks at 250 and $360 \mathrm{~nm}$, which is similar to previously reported results (Jung et al., 2013). The feed solution concentration was measured as $1.03 \pm 0.17 \mathrm{mg} / \mathrm{L}$. The size distributions obtained by DLS, NTA and AUC are reported in Figure 2-3.
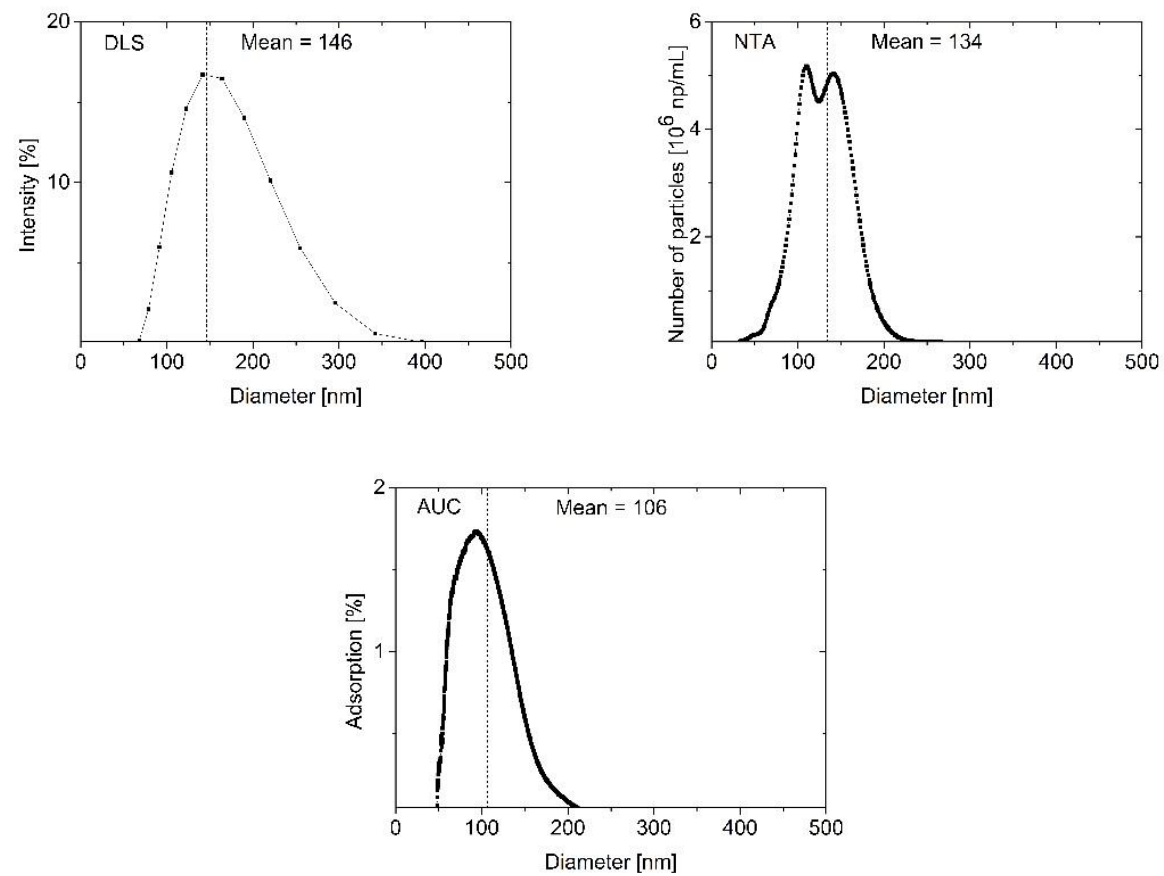

Figure 2-3: $n C_{60}$ size distributions with mean values (dashed lines): a) Intensity by DLS; $b$ ) Number of particles by NTA; c) Adsorption by AUC.

Similar and almost mono-modal asymmetric distributions were obtained. Next to the three different size distributions Figure 2-3 also reports the mean particle size. The three size characterization techniques showed comparable results considering that these are based on different principles and measure different quantities: DLS measures the variation in intensity of scattered light, AUC determines UV adsorption by particles after separation in a 


\section{Chapter 2}

concentration gradient, and NTA tracks (fluorescent) particles. For DLS, the distribution of the intensity is weighted based on the scattering intensity of each particle, which is proportional to the sixth power of the particle radius. This explains the presence of larger particles in the distribution (Figure 2-3a). Despite of the differences in the size ranges detected by the different techniques, the size distributions show rather similar average values (Figure 2-3). NTA measurements indicate a bimodal size distribution (Figure 2-3b) which is most likely due to an artefact of the applied model used to interpret the NTA data or a consequence of the limited number of frames per particle analysed (Montes-Burgos et al., 2010). DLS is known to be problematic in detecting multimodal distributions (Dieckmann et al., 2009). However, the second peak is not detected by AUC (Figure 2-3c) whereas this is the only technique performing a sample fractionation during the measurements. AUC has higher resolution and accuracy compared to DLS and NTA (Anderson et al., 2013) and this supports the hypothesis of an artefact in the NTA size distribution. All size distributions obtained indicate that there is no overlap between the eNP size and the pore size of the UF18 and MF05 membranes. An overlap exists between particle size and pore diameter in case of the MF02 membrane. The largest sizes detected by NTA and AUC are in the range of 200$228 \mathrm{~nm}$ overlapping the MF02 membrane pore sizes. Despite of the small relative amount ( $2 \%$ and $0.4 \%$ respectively) this can play a role in the removal and removal mechanism of $\mathrm{nC}_{60}$, as discussed later in this paper.

\subsubsection{Clean water flux measurements}

Prior to each experiment milli-Q water was filtered at $0.5 \mathrm{~L} / \mathrm{h}$ for at least 1 hour or until a constant TMP was achieved to evaluate the clean water permeability of the membranes. When a constant TMP was not reached after 2 hours of filtration the membrane module was discarded and replaced with a new one. Table 2-3 shows the clean water permeability for all 3 different membranes at a constant feed water flux together with the membrane resistance, calculated by Equation (10) and Equation (5) respectively. 
Table 2-3: Water permeability and corresponding resistance calculated according to Equations 10 and 5 respectively.

\begin{tabular}{llll}
\hline & UF18 & MF02 & MF05 \\
\hline Permeability $\left(10^{3} \mathrm{~L} / \mathrm{m}^{2} \cdot\right.$ hour bar $)$ & $0.87 \pm 0.07$ & $5.05 \pm 0.45$ & $8.3 \pm 0.19$ \\
Membrane resistance $\left(10^{11} \mathrm{1} / \mathrm{m}\right)$ & 4.3 & 0.7 & 0.5 \\
\hline
\end{tabular}

Differences in values between the 3 membranes are the result of variations in several membrane morphological parameters such as porosity, tortuosity and pore interconnections (Alspach et al., 2008). The permeability values are within the typical range for UF and MF membranes (Mulder, 1991). These values will be used for the permeability recovery calculation of each membrane and to verify the stability and integrity of each membrane module.

\subsubsection{Removal efficiency}

The removal efficiency was observed to be dependent of the membrane pore size (Table 24).

Table 2-4: Membrane rejection of $\mathrm{nC}_{60}$

\begin{tabular}{llll}
\hline Membrane & UF18 & MF02 & MF05 \\
\hline Pore Size [nm] & 18 & 200 & 500 \\
Rejection [\%] & 99 & 99 & 10 \\
\hline
\end{tabular}

The tight membrane (UF18) with pore sizes smaller than the nanoparticle diameter removed more than $99 \%$ of the $\mathrm{nC}_{60}$ dispersed in water. As the minimum $\mathrm{nC}_{60}$ size determined was larger than the membrane pore size, the main removal mechanism is size exclusion, as expected from the theoretical framework (Figure 2-1a). However small amounts of $\mathrm{nC}_{60}$ were detected in the permeate samples $(\sim 8 \mu \mathrm{g} / \mathrm{L})$. This can be attributed to an overlap between the membrane pore size and the $\mathrm{nC}_{60}$ size distribution, which could not be identified by our measurements. Another explanation was the existence of (i) nanoparticle clusters smaller than $18 \mathrm{~nm}$ or (ii) membrane pore sizes larger than the smallest eNPs cluster size measured 
(25 $\mathrm{nm}$ by NTA and $50 \mathrm{~nm}$ by DLS and AUC) occur. Another explanation if clustersqueezing or partial cluster disaggregation due to the pressure gradient applied to the membrane interface (Jassby et al., 2010). The obtained removal efficiency was about 20\% higher than the values reported in literature with similar membrane pore sizes (Jassby et al., 2010). This difference is hard to explain because detailed characterization of the ceramic membrane used by Jassby et al. is lacking. Furthermore, differences exist in the applied experimental conditions (e.g.: initial feed concentration, dispersion volume filtered, filtration operation system, analytical method). The authors attributed the non-complete removal of $\mathrm{nC}_{60}$ to an overlap between the particle size distribution and the membrane pore size revealed by intensity-weighted PSD measurements of $\mathrm{nC}_{60}$ dispersions.

High removal (99\%) of $\mathrm{nC}_{60}$ was also observed for $\mathrm{MF02}$ despite the fact that the membrane pore size is predominantly larger than the size of $\mathrm{nC}_{60}$. In this case, the smaller clusters of $\mathrm{nC}_{60}$ particles are expected to penetrate the membrane structure and either deposit on it or permeate through (Figure 2-1b), whereas larger clusters of $\mathrm{nC}_{60}$ particles most likely deposit on the membrane surface either blocking or narrowing the membrane pores. The removal mechanism can be attributed to a combination of external deposition on and internal deposition in the membrane as will be further discussed in the membrane autopsy section. Removal results can also be affected by the duration of the experiments: longer filtration times could lead to a complete saturation of the membrane internal deposition volume available leading to a subsequent $\mathrm{nC}_{60}$ break-through. We could not observe this within the time frame of 6 cycles. The complete saturation of the internal membrane volume available for internal deposition can be expected after approximately 37 filtration cycles following a linear regression of the permeability recovery of MF02 in time (Figure 2-5, discussed later) assuming that the permeability linearly decreases as filtration continues. As expected, the MF05 membrane showed a low $\mathrm{nC}_{60}$ removal of $10 \%$, which can be explained from the removal scenario indicated in Figure 2-1c. Free energy of adhesion calculations were performed using the Young-Dupré equation using surface tension components obtained from literature (Table 2-5). 
Table 2-5: Surface tensions components and free energy of adhesion calculation.

\begin{tabular}{lllll}
\hline & $\gamma^{\mathbf{L W}}\left(\mathbf{m} \mathbf{J} / \mathbf{m}^{2}\right)$ & $\gamma^{+}\left(\mathbf{m} \mathbf{J} / \mathbf{m}^{2}\right)$ & $\gamma^{-}\left(\mathbf{m} \mathbf{J} / \mathbf{m}^{2}\right)$ & $\Delta$ GMws \\
\hline Water & 21.8 & 25.5 & 25.5 & \\
Fullerenes* & 43.16 & 0.61 & 1.66 & \\
PES** & 43 & 0.5 & 0.1 & -80.26 \\
PVP*** & 43 & 0 & 29.7 & -41.75 \\
\hline
\end{tabular}

* data obtained from (Henry and Brant, 2012); ** data obtained from (Cornelissen and Strathmann, 1998); *** data obtained from (Oss, 2006).

Calculations resulted in negative values for both polymers (PES and PVP) (Table 2-5) indicating that adhesion between $\mathrm{nC}_{60}$ and the membrane material is expected.

Possible fractionation effects on the eNP size distribution during filtration were investigated by comparing the feed size distribution with the permeate size distribution. Due to the low $\mathrm{nC}_{60}$ concentration in the UF18 and MF02 permeate samples the analysis was only conducted for the MF05 permeate samples and samples were analysed by DLS only. Permeate samples collected during filtration cycle number one, two, four and six showed the same average and polydispersity index values as the feed size distribution. This indicated that each size fraction is rejected at the same degree $(10 \%)$. 


\subsubsection{TMP and permeability recovery (backwash efficiency)}

During filtration when $\mathrm{nC}_{60}$ is retained by the membrane, the filtration resistance increases in time resulting in an increase in TMP during filtration at constant flux. The typical effect of $\mathrm{nC}_{60}$ deposition on TMP during 6 filtration cycles (5 filtration cycles for the UF18 membrane) and 6 backwash cycles is presented in Figure 2-4.

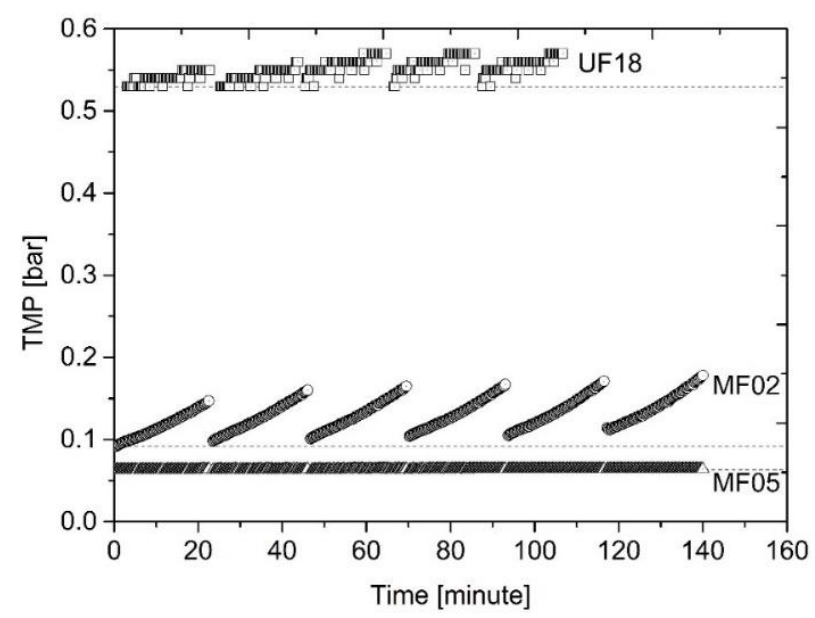

Figure 2-4: Increase of the feed pressure due to $n$ C60 deposition. Dashed line represents initial feed pressure.

During constant flux filtration, the TMP increases due to the retention of $\mathrm{nC}_{60}$ and its deposition on and in the membrane for the UF18 and the MF02 membrane. Differences in initial TMP values for the 3 different membranes (see pure water flux section) are caused by differences in the membrane resistance due to differences in membrane porosity and membrane pore structure. During UF18 filtration the TMP increase per cycle is $31 \pm 6$ mbar on average and after the backwash procedure the initial TMP is almost completely restored (Fig 2-4). For the MF02 membrane, the TMP increase per cycle is $59 \pm 8$ mbar on average, but the initial TMP was not restored after backwash cleaning (Fig 2-4). The initial TMP before each filtration cycle kept increasing suggesting the occurrence of internal particle deposition (Lohwacharin and Takizawa, 2009). 


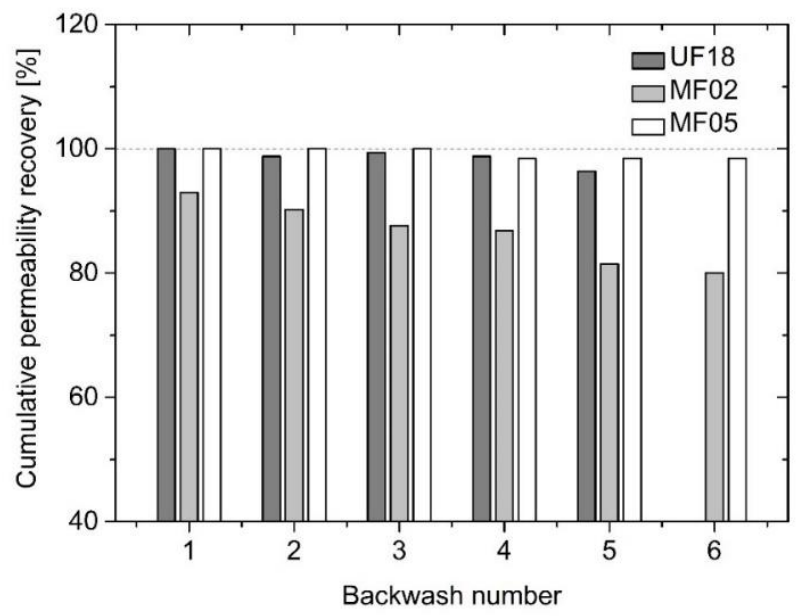

Figure 2-5: Cumulative permeability recovery versus number of backwash cycles.

After each filtration cycle, the initial permeability of the UF18 membrane is recovered by the backwash up to $99 \pm 1 \%$ (Fig 2-5). In contrast, the permeability recovery of the MF02 membrane showed a decreasing trend between the first and the last cycle from $93 \%$ to $81 \%$ (Figure 2-5). This indicates the occurrence of pore entrapment and/or pore narrowing (Lohwacharin and Takizawa, 2009) (Figure 2-1b). The deposition of $\mathrm{nC}_{60}$ on MF05 did not significantly affect the TMP pressure during the experiments $(1$ mbar increase over 6 filtration cycles) and consequently the effect of the backwash procedure on the initial permeability was not observed. 


\section{Chapter 2}

The visual effects of the deposition of $\mathrm{nC}_{60}$ on the inner membrane surface after 6 filtration cycles and backwash cycles (5 filtration cycles for the UF18 membrane) are presented in Figure 2-6.

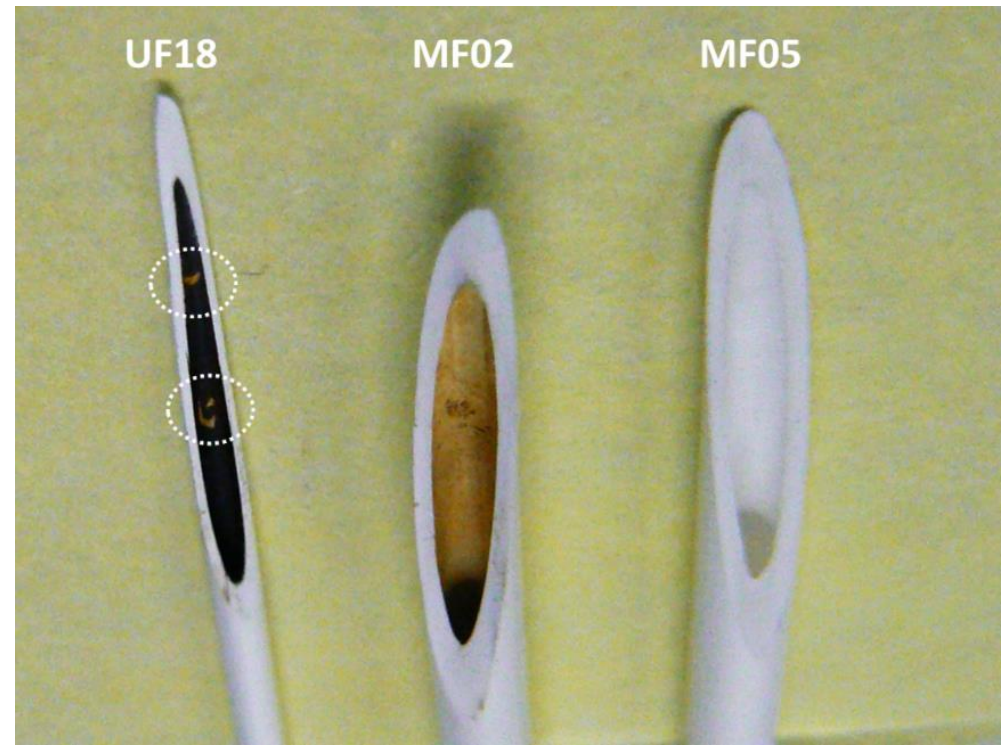

Figure 2-6: Autopsy photo of UF18, MF02 and MF05 after 6 filtration and backwash cycles (5 for the UF18 membrane).

The lumen surface of the 3 membranes after $\mathrm{nC}_{60}$ filtration was visually very different. Although the initial membrane permeability was efficiently recovered after 5 backwash cycles, the inner membrane surface of the UF18 membrane was covered by a homogeneous dark brownish/blackish deposition layer consisting of $\mathrm{nC}_{60}$ (Figure 2-6a). Some chunks of the deposition layer were removed, which can be visually observed in Figure 2-6 by the lighter shades in the deposited black layer as indicated by white circles. A light brownishyellowish more irregular deposition was observed for the MF02 membrane (Figure 2-6b). Hardly any deposition was observed for the MF05 membrane (Figure 2-6c), probably linked to the low nanoparticle removal. Changes in colour of the UF18 deposition layers can also be an indication of changes in the $\mathrm{nC}_{60}$ stability. Particles not removed from the membrane surface during the backwash procedure will increase the cake layer thickness and experience an increasing pressure difference, eventually giving rise to compression effects of the deposition layer (Braus et al., 2002). Deposition layer compression can ultimately bring eNPs 
beyond the energy barrier distance compromising their colloidal stability (Tang et al., 2011; Yiantsios and Karabelas, 1998). It has been shown that changes in size, structure, and/or interactions between the colloidal particles and solvent molecules can lead to colour changes (Gallagher et al., 1995) and this can also be the case of the changes in colours of the particle deposition layer observed here. More research is needed to clarify whether the fullerene on the deposition layer is still in colloidal state or solid precipitate. Differences in the physical status of fullerene can result in different degree of compaction of the deposition layer, which can affect both membrane performance (permeability decrease and $\mathrm{nC}_{60}$ removal) and the efficiency of the backwash cleaning procedure. 


\section{Chapter 2}

SEM photos of the internal membrane surfaces are presented in Figure 2-7.

\section{Bored side}
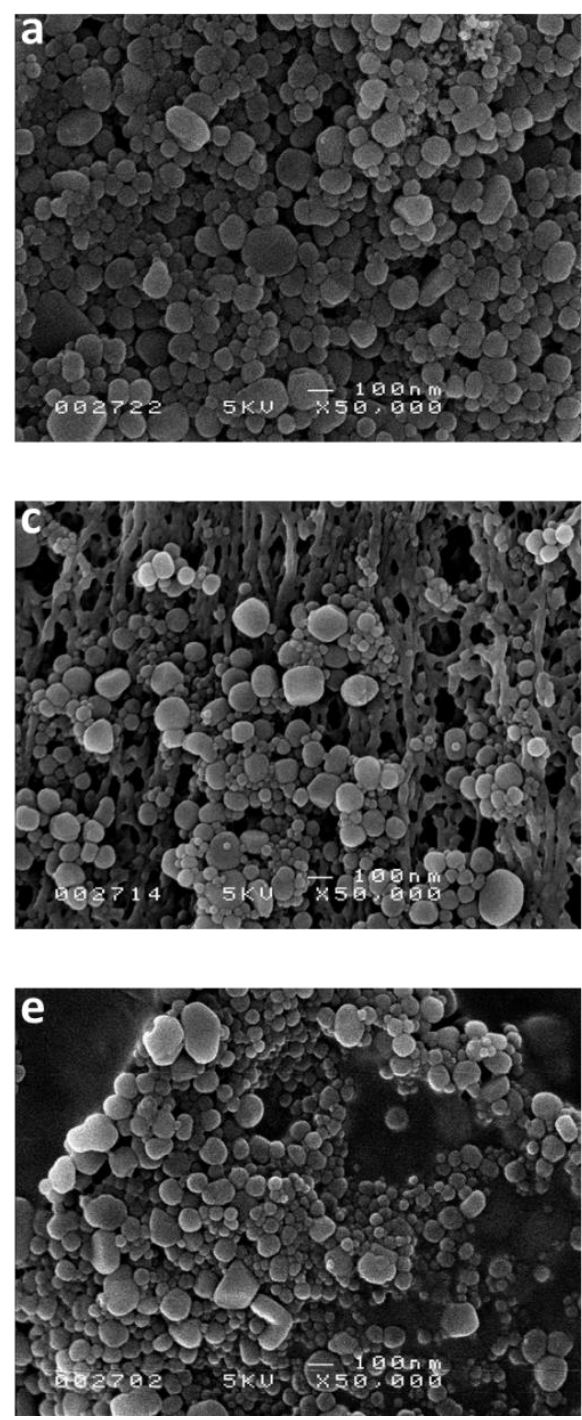

\section{Cross section}
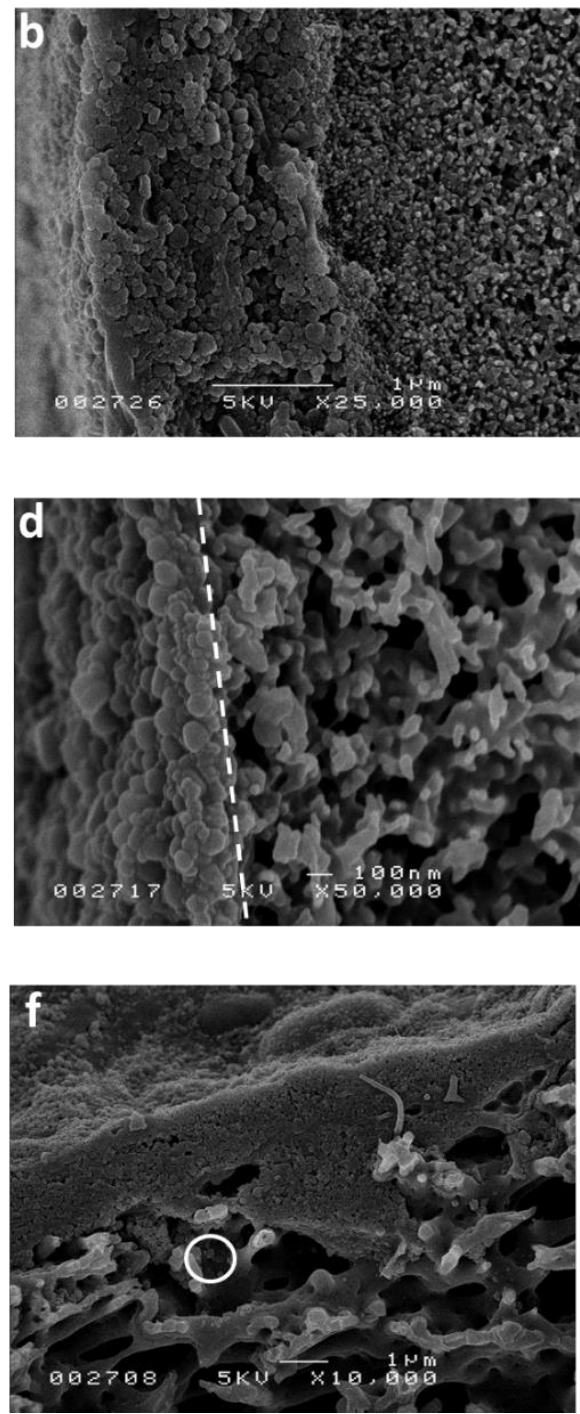

Figure 2-7: SEM images of fouled membranes after 6 filtration and backwash cycles (5 for the UF18 membrane): a) UF18 bore side; b) UF18 cross section; c) MF02 bore side; d) MF02 cross section; e) MF05 bore side; f) MF05 cross section. 
The inner/bore side surface of the UF18 hollow fiber membranes was covered by a compact deposition layer (Figure 2-7a) with a thickness ranging from 1 to $6 \mu \mathrm{m}$ (Figure 2-7b). This is in agreement with the stipulation that during the filtration experiments particles are not removed by the backwash procedure, instead they accumulate on the membrane surface. Residuals of a deposited cake layer appeared also on the bore side surface of the MF02 membrane. However, the inner/bore side surface was not fully covered (Figure 2-7c). If a cake-layer was observed on the SEM picture the thickness of the layer deposited was about $100 \mathrm{~nm}$ (Figure 2-7d). As expected, removal mainly occurred by external surface deposition visible as a cake layer and pore blocking instead of internal deposition. This resulted in a severe permeability loss as shown in Figure 2-5. Surface deposition was also observed on the bore side MF05 membrane surface as a consequence of $10 \%$ removal of $\mathrm{nC}_{60}$ from the feed water. Regarding the MF05 the deposition was identified only on the feed side. The permeate side of the membrane appeared clean (image not shown here) in spite the presence of $\mathrm{nC}_{60}$ on the backwash water due to incomplete retention of the eNPs. Particle deposition seems to be localized into the valleys of the rough surface structure (Figure 2-7e and 2-7f). If adhesion was occurring both at the feed and permeate side, the membrane would be (partially) covered by a $\mathrm{nC}_{60}$ deposition layer on both sides. Since this was not observed from the autopsy study using $\mathrm{SEM}$, adhesion between $\mathrm{nC}_{60}$ and the membrane material is not expected to be the mechanism to responsible for $10 \% \mathrm{nC}_{60}$ removal with the $\mathrm{MF} 05$ membrane. Most likely the adhesion effects are overshadowed by electrostatic repulsion effects between the negatively charged membranes (Table 2-1) and negatively charged $\mathrm{nC}_{60}(-79.3 \pm 10.9 \mathrm{mV})$. Thus, the $10 \%$ removal is attributed to surface deposition mainly occurring due to the roughness of the membrane surface (Figure 2-7f). Deposition in the internal membrane structure has been identified by SEM analysis (white circle in Figure 2-7f) in lower amounts than the surface deposition thought we exclude sorption phenomena due to $\mathrm{nC}_{60}$ and membrane interfacial affinity. This is in in accordance with removal efficiency results discussed previously in section 4.3. Differences in ratio of the cake-layer deposition resistance to the clean membrane resistance between the UF18 and MF02 explain the differences in the efficiency of removing the $\mathrm{nC}_{60}$ surface deposition by the backwash procedure. Resistance values (Table 2-6) were calculated by the resistance in series model (Cho et al., 1999; Hong and Elimelech, 1997). 
Table 2-6: Clean membrane and total hydraulic resistance calculated according to Equations 5 and 6 respectively.

\begin{tabular}{llll}
\hline & UF18 & MF02 & MF05 \\
\hline Clean membrane resistance $\left(10^{11} 1 / \mathrm{m}\right)$ & 4.3 & 0.7 & 0.5 \\
Total hydraulic resistance $\left(10^{11} 1 / \mathrm{m}\right)$ & 4.4 & 1.1 & 0.5 \\
\hline
\end{tabular}

In the case of the UF18 it was calculated that the hydraulic resistance of the deposition layer was one order of a magnitude lower than the clean membrane resistance. In these conditions the membrane structure dissipates most of the hydraulic shear stresses generated by the backwash flux. These results in a lower amount of energy available for the removal of the deposited cake layer compared to the MF02 membrane. Figure 2-8 shows the ratio of the cake-layer deposition resistance to the clean membrane resistance versus the backwash cycle for the UF18 and the MF02 membranes.

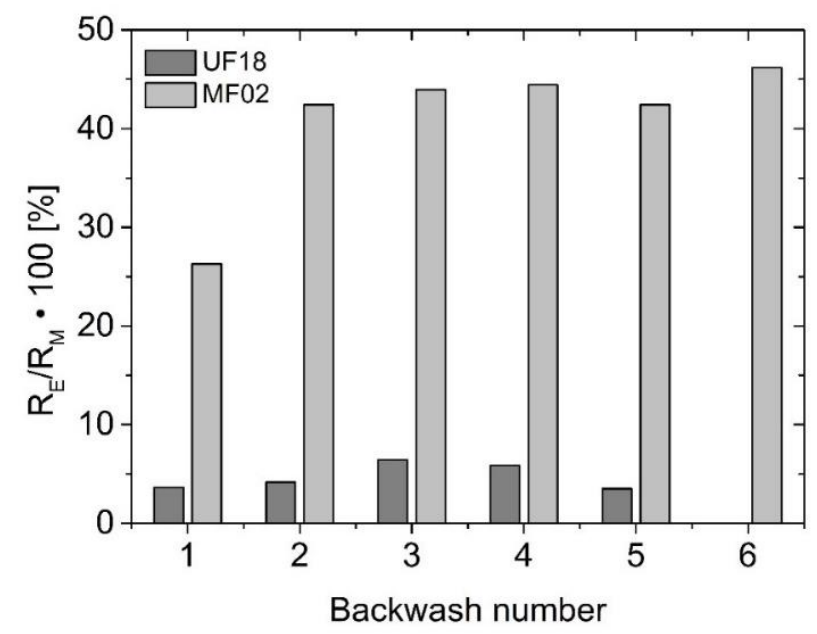

Figure 2-8: Ratio of cake layer deposition resistance to clean membrane resistance versus number of backwash cycles.

The contribution of the external deposition to the total filtration resistance in case of the UF18 was only $\sim 5 \%$ (on average) with a very small variation within the 5 filtration cycles $( \pm 1.4 \%)$. In contrast, the contribution of the external deposition to the total filtration resistance in case 
of the MF02 membrane was $\sim 26 \%$ during the first filtration cycle and stabilized in the following cycles at $\sim 44 \pm 1.6 \%$. Moreover, the presence of removed chunks (lighter colour of deposited black layer as indicated by white circles in Figure 2-6) in the UF18 deposited cakelayer might eventually act as preferential flow pathways for the backwash flux reducing the potential cleaning effect of the backwash procedure. Similarly, the formation of fractures in the deposition layer itself as shown in Figure 2-9 can lead as well to preferential flow paths.

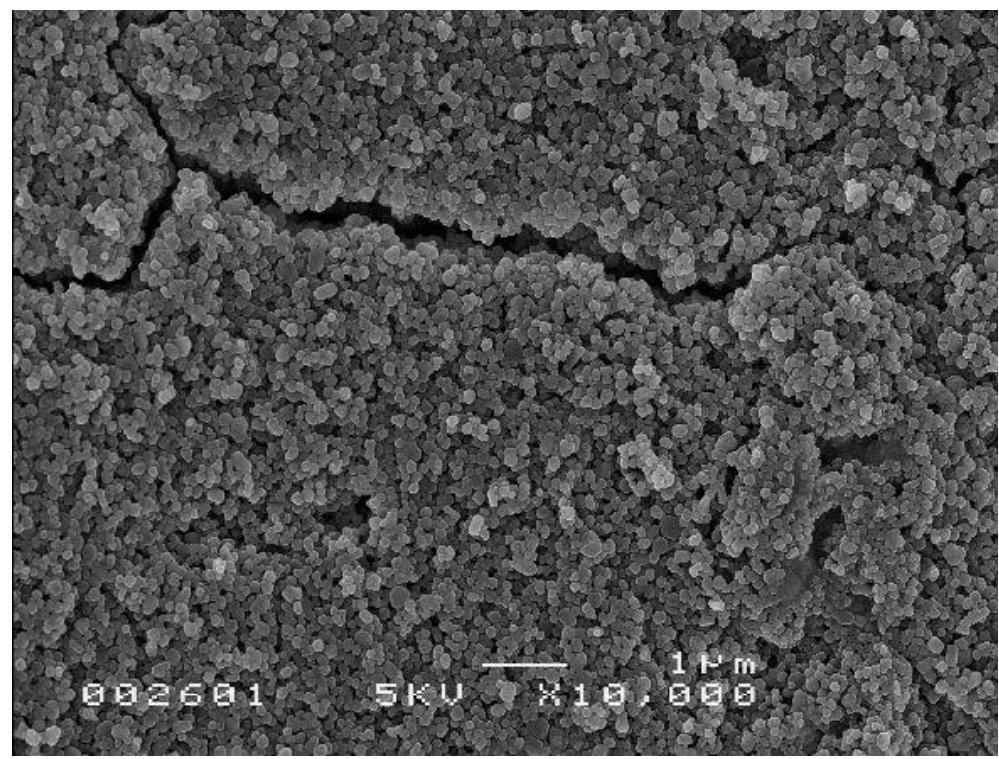

Figure 2-9: SEM photo of fractured deposition layer on UF18 membrane.

However, the fractures in Figure 2-9 can also be the results of the sample drying preparation procedure for the SEM. 


\subsubsection{Application of the blocking laws for constant flux low pressure membrane filtration}

Given the ratio of eNPs and membrane pore size we applied the intermediate blocking and cake formation model to the UF18 and MF02 membrane (see section 3.7). The modelling and experimental results are presented in Figure 2-10 for the first filtration cycle.
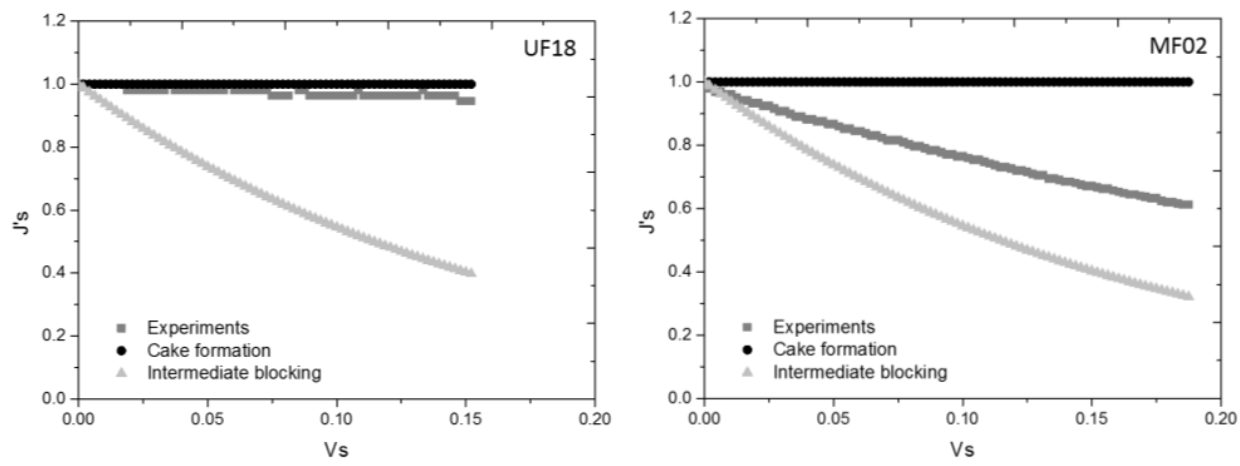

Figure 2-10: Specific flux as function of the specific permeate volume for the experimental data, cake formation and intermediate pore blocking models relative to the first filtration cycle.

The sum of squared residual values (S) (sum of squared deviations of predicted from experimental values of data) are reported in Table 2-7. S was adopted as a measure of the discrepancy between the experimental data and the model results. 
Table 2-7: The sum of squared residual values for the 2 membrane types and the filtration cycles.

\begin{tabular}{llllllll}
\hline \multicolumn{7}{c}{ Cycle number } \\
\hline Membrane & Blocking law & 1 & 2 & 3 & 4 & 5 & 6 \\
UF18 & $\begin{array}{l}\text { Cake formation } \\
\text { Intermediate }\end{array}$ & 0.1 & 0.1 & 0.2 & 0.2 & 0.2 & \\
\multirow{2}{*}{ MF02 } & 9.6 & 9.6 & 8.5 & 8.4 & 8.6 & \\
& $\begin{array}{l}\text { Clocking } \\
\text { Cake formation }\end{array}$ & 5.4 & 5.4 & 5.3 & 4.8 & 5.0 & 4.1 \\
& $\begin{array}{l}\text { Intermediate } \\
\text { blocking }\end{array}$ & 3.8 & 3.9 & 3.9 & 4.3 & 4.1 & 5.1 \\
\hline
\end{tabular}

Regarding the UF18 membrane the specific flux values from the experimental data corresponds closely $(S=0.14 \pm 0.08$ ) (Figure 2-10) to the cake formation blocking law. Although this result does not exclude that other removal and fouling mechanisms are occurring, it confirms that deposition on the membrane surface is the major removal and fouling mechanism occurring in the ultrafiltration membrane.

Regarding the MF02 membrane, the experimental specific flux decrease fall between the calculated flux decrease of the 2 blocking laws (Figure 2-10). It is therefore suggested that for the MF02 membrane both the cake formation and intermediate blocking mechanism are occurring at the same time.

\subsubsection{Discussion overall filtration behaviour under typical full- scale conditions}

$\mathrm{nC}_{60}$ dispersed in ultrapure water was efficiently removed by low-pressure membranes with an average pore size smaller and, unexpectedly, also by membranes with similar/larger than the particle size distribution. Much larger membrane pore size failed in retaining the $\mathrm{nC}_{60}$. Membranes with pore size smaller than $\mathrm{nC}_{60}$ diameter removed more than $99 \%$ reaching efficiency considerably higher than previous studies (Jassby et al., 2010) reported. Even though small amounts of $\mathrm{nC}_{60}$ were detected in the permeate samples. During 5 filtration cycles, each followed by a hydraulic backwash, the initial permeability was almost 


\section{Chapter 2}

completely recovered. Nevertheless, the majority of the deposition layer was still attached to the membrane surface at the end of the experiments. Visual observations suggest that colloidal stability of the $\mathrm{nC}_{60}$ might be compromised during the continuous accumulation of $\mathrm{nC}_{60}$. Filtration by membranes with pore sizes mostly larger than $\mathrm{nC}_{60}$ size showed an unexpected removal of $99 \%$ which occurred by external surface deposition instead of internal deposition as expected. The backwash procedure was more effective in removing the deposition cake-layer but failed in recovering the initial filtration conditions resulting in a severe permeability loss. The ratio $\mathrm{nC}_{60}$ size to membrane pore size played an important role on the removal mechanism and on the efficiency of the hydraulic backwash procedure to recover the initial membrane filtration conditions. The efficiency of the hydraulic backwash procedure recovering the initial membrane filtration conditions was found also dependent on the ratio of the cake-layer deposition resistance to the clean membrane resistance. Moreover, the efficiency of the cleaning procedure ultimately compromised the colloidal stability of the $\mathrm{nC}_{60}$ dispersion. The very low removal obtained by much larger membrane pore size (500 $\mathrm{nm}$ ) mainly occurred by deposition on the rough membrane structure. We observed no particularly relevant adsorption phenomena between the $\mathrm{nC}_{60}$ and the membrane material. However, differently from previous work (Ladner et al., 2011) in this study the membrane surface proprieties played an important role in controlling the filtration behaviour of eNPs as well as their stability.

\subsection{Conclusion}

The effect of membrane pore size on the removal and on the removal mechanism of $\mathrm{nC}_{60}$ by low pressure membrane filtration including multiple backwash cycles was addressed. Multiple filtration and backwash cycles gave relevant insight in the filtration behaviour of $\mathrm{nC}_{60}$ with low pressure membranes. Commercially available low pressure membranes efficiently removed $\mathrm{nC}_{60}$ under typical full-scale conditions (i.e. constant flux operating mode in dead-end membrane systems). Water treatment plants which include low pressure membrane processes are a viable barrier in minimizing human exposure to $\mathrm{nC}_{60}$ via ingestion. However, the membrane permeability during filtration and the efficiency of the backwash cleaning procedure can be strongly influenced by the ratio $\mathrm{nC}_{60}$ size to membrane pore size. 
These results become particularly significant in the context of the drinking water production, they give relevant information for an accurate selection between membrane processes and operational parameters for the removal of $\mathrm{nC}_{60}$ in the drinking water treatment. The work presented here provides systematic fundamental insights on the specific interactions of $\mathrm{nC}_{60}$ and the membranes and forms an essential understanding basis for future researches that include the use of natural waters. Further investigation is recommended to validate these findings in more environmentally relevant conditions addressing the role of water quality parameters on the filtration behaviour of $\mathrm{nC}_{60}$.

\section{Acknowledgement}

This research is sponsored by the Joint Research Programme of KWR Watercycle Research Institute for the Dutch Drinking Water Companies and is supported by NanoNextNL, a micro and nanotechnology consortium of the Government of the Netherlands and 130 partners. For the nanoparticle size distribution analysis, this research received also support from the QualityNano Project which is financed by the European Community Research Infrastructures under the FP7 Capacities Programme (Grant No. INFRA-2010-262163) and its partner University College Dublin. The authors would also like to acknowledge Marco Monopoli and Eugene Mahon (University College of Dublin) for the support in the nanoparticles size measurements, Herman Teunis (European Membrane Institute Twente) for the SEM analysis, Jens Potreck (Pentair X-Flow) for providing the membranes. The authors would specially like to thank Harry van Wegen and Sydney Meijering for building the installation set-up and their infinite help in developing the set-up. 


\section{References}

Agarwal, C., Pandey, A.K., Das, S., Sharma, M.K., Pattyn, D., Ares, P., Goswami, A., 2012. Neck-size distributions of through-pores in polymer membranes. J. Memb. Sci. 415-416, 608-615.

Akamatsu, K., Han, F., Kaneko, Y., Nakao, S., 2010. Crossflow ultrafiltration properties of monodisperse nanoparticle suspensions in laminar flow. J. Chem. Eng. Japan 43, 938-945.

Alspach, B., Adham, S., Cooke, T., Delphos, P., Garcia-Aleman, J., Jacangelo, J., Karimi, A., Pressman, J., Schaefer, J., Sethi, S., 2008. Microfiltration and ultrafiltration membranes for drinking water. J. Am. Water Work. Assoc. 100, 84-97.

Anderson, W., Kozak, D., Coleman, V.A., Jämting, Å.K., Trau, M., 2013. A comparative study of submicron particle sizing platforms : Accuracy, precision and resolution analysis of polydisperse particle size distributions. J. Colloid Interface Sci. 405, 322-330.

Ariza, M.J., Benavente, J., 2001. Streaming potential along the surface of polysulfone membranes: a comparative study between two different experimental systems and determination of electrokinetic and adsorption parameters. J. Memb. Sci. 190, 119-132.

Baalousha, M., Stolpe, B., Lead, J.R., 2011. Flow field-flow fractionation for the analysis and characterization of natural colloids and manufactured nanoparticles in environmental systems: a critical review. J. Chromatogr. 1218, 4078-103.

Baena, J.R., Gallego, M., Valca, M., Division, A.C., 2002. Fullerenes in the analytical sciences. Trends Anal. Chem. 21, 187-198.

Benn, T.M., Westerhoff, P., Herckes, P., 2011. Detection of fullerenes (C60 and C70) in commercial cosmetics. Environ. Pollut. 159, 1334-42.

Braus, E., Hoof, E. Van, Molenberghs, B., Dotremont, C., Doyen, W., Leysen, R., 2002. A new method of measuring and presenting the membrane fouling potential. Desalination 150, $31-43$.

Chae, S.-R., Wang, S., Hendren, Z., Wiesner, M., Watanabe, Y., Gunsch, C., 2009. Effects of fullerene nanoparticles on Escherichia coli K12 respiratory activity in aqueous suspension and potential use for membrane biofouling control. J. Memb. Sci. 329, 68-74.

Chen, K.L., Elimelech, M., 2007. Influence of humic acid on the aggregation kinetics of fullerene (C60) nanoparticles in monovalent and divalent electrolyte solutions. J. Colloid Interface Sci. 309, 126-134.

Cho, J., Amy, G., Pellegrino, J., 1999. Membrane filtration of natural organic matter: initial comparison of rejection and flux decline characteristics with ultrafiltration and nanofiltration. Water Res. 33, 2517-2526.

Cornelissen, E.R., Strathmann, H., 1998. Physicochemical aspects of polymer selection for ultrafiltration and microfiltration membranes. Colloids Surfaces A Physicochem. Eng. Asp. 138, 283-289. 
Crozes, G., Anselme, C., Mallevialle, J., 1993. Effect of adsorption of organic matter on fouling of ultrafiltration membranes. J. Memb. Sci. 84, 61-77.

Crozes, G.F., Jacangelo, J.G., Anselme, C., La, J.M., 1997. Impact of ultrafiltration operating conditions on membrane irreversible fouling. J. Memb. Sci. 124, 63-76.

Deguchi, S., Alargova, R.G., Tsujii, K., 2001. Stable Dispersions of Fullerenes , C 60 and C 70 , in Water . Preparation and Characterization. Langmuir 17, 6013-6017.

Dieckmann, Y., Colfen, H., Hofmann, H., Petri-fink, A., 2009. Particle Size Distribution Measurements of Manganese-Doped ZnS Nanoparticles. Anal. Chem. 81, 3889-3895.

Fane, A.G., Xi, W., Rong, W., 2006. Interface Science in Drinking Water Treatment - Theory and Application, Interface Science and Technology. Elsevier.

Filipe, V., Hawe, A., Jiskoot, W., 2010. Critical evaluation of Nanoparticle Tracking Analysis (NTA) by NanoSight for the measurement of nanoparticles and protein aggregates. Pharm. Res. 27, 796-810.

Gallagher, S.H., Armstrong, R.S., Lay, P.A., Reed, C.., 1995. Solvent effects on the electronic spectrum of C60. J. Pysical Chemestry 99, 5817-5825.

Guldi, D., Prato, M., 2000. Excited-State Properties of C60 Fullerene Derivatives. Acc. Chem. Res. 33, 695-703.

Guo, H., Wyart, Y., Perot, J., Nauleau, F., Moulin, P., 2010. Application of magnetic nanoparticles for UF membrane integrity monitoring at low-pressure operation. J. Memb. Sci. 350, 172-179.

Guo, H., Wyart, Y., Perot, J., Nauleau, F., Moulin, P., Ce, P., 2010. Low-pressure membrane integrity tests for drinking water treatment: A review. Water Res. 44, 41-57.

Henry, C., Brant, J. a., 2012. Mechanistic analysis of microfiltration membrane fouling by buckminsterfullerene (C60) nanoparticles. J. Memb. Sci. 415-416, 546-557.

Henry, C., Dorr, B., Brant, J. a., 2012. Buckminsterfullerene (C60) nanoparticle fouling of microfiltration membranes operated in a cross-flow configuration. Sep. Purif. Technol. 100, $30-43$.

Heymann, D., 1996. Solubility of Fullerenes C60 and C70 in Seven Normal Alcohols and Their Deduced Solubility in Water. Fuller. Sci. Technol. 4, 543-544.

Hofmann, T., von der Kammer, F., 2009. Estimating the relevance of engineered carbonaceous nanoparticle facilitated transport of hydrophobic organic contaminants in porous media. Environ. Pollut. 157, 1117-26.

Hong, S., Elimelech, M., 1997. Chemical and physical aspects of natural organic matter (NOM) fouling of nanofiltration membranes. J. Memb. Sci. 132, 159-181.

Howe, K.J., Marwah, A., Chiu, K.-P., Adham, S.S., 2007. Effect of membrane configuration on bench-scale MF and UF fouling experiments. Water Res. 41, 3842-9.

Huang, H., Lee, N., Young, T., Gary, A., Lozier, J.C., Jacangelo, J.G., 2007. Natural organic matter fouling of low-pressure, hollow-fiber membranes: Effects of NOM source and hydrodynamic conditions. Water Res. 41, 3823-32. 
Huang, H., Young, T., Jacangelo, J.G., 2008. Unified Membrane Fouling Index for Low Pressure Membrane Filtration of Natural Waters : Principles and Methodology. Environ. Sci. Technol. 42, 714-720.

Jafvert, C.T., Kulkarni, P.P., 2008. Buckminsterfullerene's (C60) octanol-water partition coefficient (Kow) and aqueous solubility. Environ. Sci. Technol. 42, 5945-5950.

Jassby, D., Chae, S.-R., Hendren, Z., Wiesner, M., 2010. Membrane filtration of fullerene nanoparticle suspensions: effects of derivatization, pressure, electrolyte species and concentration. J. Colloid Interface Sci. 346, 296-302.

Jung, Y.K., Kim, M.J., Kim, Y.-J., Kim, J.Y., 2013. Limitation of UV-Vis absorption analysis for determination of aqueous colloidal fullerene (nC60) at high ionic strength. KSCE J. Civ. Eng. 17, 51-59.

Kolkman, A., Emke, E., Bäuerlein, P.S., Carboni, A., Tran, D.T., ter Laak, T.L., van Wezel, A.P., de Voogt, P., 2013. Analysis of (functionalized) fullerenes in water samples by liquid chromatography coupled to high-resolution mass spectrometry. Anal. Chem. 85, 5867-74.

Kroto, H.W., Heath, J.R., O’Brien, S.C., Curl, R.F., Smalley, R.E., 1985. C60: Buckminsterfullerene. Nature 318, 162.

Ladner, D., Steele, M., Weir, A., Hristovski, K., Westerhoff, P., 2011. Functionalized nanoparticle interactions with polymeric membranes. J. Hazard. Mater. 211-212, 288-295.

Li, D., Frey, M.W., Joo, Y.L., 2006. Characterization of nanofibrous membranes with capillary flow porometry. J. Memb. Sci. 286, 104-114.

Li, Y., Zhang, W., Zhang, X., Chen, C., Wang, J., 2010. Characterization of fouling in immersed polyvinylidene fluoride hollow fibre membrane ultrafiltration by particles and natural organic matter. Desalin. water Treat. 18, 2010.

Lohwacharin, J., Takizawa, S., 2009. Effects of nanoparticles on the ultrafiltration of surface water. J. Memb. Sci. 326, 354-362.

Lyon, D.Y., Adams, L.K., Falkner, J.C., Alvarezt, P.J.J., 2006. Antibacterial activity of fullerene water suspensions: effects of preparation method and particle size. Environ. Sci. Technol. 40, 4360-6.

Montes-Burgos, I., Walczyk, D., Hole, P., Smith, J., Lynch, I., Dawson, K., 2010. Characterisation of nanoparticle size and state prior to nanotoxicological studies. J. Nanoparticle Res. 12, 47-53.

Mulder, M., 1991. Basic principles of membrane technology, second edi. ed. Kluver Academic Publishers.

Murayama, H., Tomonoh, S., Alford, J.., Karpuk, M.E., 2004. Fullerene production in tons and more: From science to industry. Fullerenes Nanotub. Carbon Nanostructures 12, 1-9.

Navarro, E., Baun, A., Behra, R., Hartmann, N.B., Filser, J., Miao, A.-J., Quigg, A., Santschi, P.H., Sigg, L., 2008. Environmental behavior and ecotoxicity of engineered nanoparticles to algae, plants, and fungi. Ecotoxicology 17, 372-86.

Osawa, E., 2002. Perspective of Fullerene Nanotechnology. Berlin, Germany. 
Oss, C.J.. van, 2006. Interfacial Forces in Aqueous Media, Second Edition, in: Interfacial Forces in Aqueous Media, Second Edition. CRC Press.

Sayes, C.M., Gobin, A.M., Ausman, K.D., Mendez, J., West, J.L., Colvin, V.L., 2005. NanoC60 cytotoxicity is due to lipid peroxidation. Biomaterials 26, 7587-95.

Schafer, A.I., 2000. Microfiltration of colloids and natural organic matter. J. Memb. Sci. 171, 151-172.

Singh, R., 2015. Membrane Technology and Engineering for Water Purification. Elsevier.

Song, M., Yuan, S., Yin, J., Wang, X., Meng, Z., Wang, H., Jiang, G., 2012. Size-dependent toxicity of nano-C60 aggregates: more sensitive indication by apoptosis-related Bax translocation in cultured human cells. Environ. Sci. Technol. 46, 3457-64.

Stone, V., Nowack, B., Baun, A., van den Brink, N., Kammer, F. Von Der, Dusinska, M., Handy, R., Hankin, S., Hassellöv, M., Joner, E., Fernandes, T.F., 2010. Nanomaterials for environmental studies: classification, reference material issues, and strategies for physicochemical characterisation. Sci. Total Environ. 408, 1745-54.

Tang, C.Y., Chong, T.H., Fane, A.G., 2011. Colloidal interactions and fouling of NF and RO membranes: a review. Adv. Colloid Interface Sci. 164, 126-43.

Tarabara, V.V., Hovinga, R.M., Wiesner, M.R., 2002. Constant transmembrane pressure vs. constant permeate flux: Effect of particle size on crossflow membrane filtration. Environ. Eng. Sci. 19, 343-355.

Xie, Q.-L., Liu, J., Xu, X.-X., Han, G.-B., Xia, H.-P., He, X.-M., 2009. Size separation of Fe2O3 nanoparticles via membrane processing. Sep. Purif. Technol. 66, 148-152.

Yiantsios, S.G., Karabelas, A.J., 1998. The effect of colloid stability on membrane fouling. Desalination 9164, 143-152.

Zhu, S., Oberdorster, E., Haasch, M.L., 2006. Toxicity of an engineered nanoparticle (fullerene, C60) in two aquatic species, Daphnia and fathead minnow. Mar. Environ. Res. 62, 5-9. 


\section{EFFECT OF}

\section{MULTICOMPONENT FOULING}

\section{DURING MICROFILTRATION OF}

\section{NATURAL SURFACE WATERS}

\section{CONTAINING nC60 FULLERENE NANOPARTICLES}

This chapter has been submitted as:

Floris, R., Moser, G., Nijmeijer, K., Cornelissen, E.R.,

Effect of multicomponent fouling during microfiltration of natural surface waters containing $\mathrm{nC}_{60}$ fullerene nanoparticles

to Environmental Science: Water Research \& Technology 


\begin{abstract}
To understand and mitigate the role of surface water composition and associated membrane fouling in the removal of $\mathrm{nC}_{60}$ nanoparticles by low-pressure membranes, experiments were carried out with microfiltration membranes using natural feed waters, mimicking separation in real industrial water treatment plants. Effect of water composition, the presence of nanoparticles, and membrane fouling was investigated with a dead-end bench-scale system operated at constant flux conditions including a hydraulic backwash cleaning procedure. $\mathrm{nC}_{60}$ nanoparticles can be efficiently removed by microfiltration and the removal efficiency is found to be independent of the water surface composition. However, the water composition controls the extent of fouling occurring during filtration. A synergistic effect on membrane fouling between $\mathrm{nC}_{60}$ and surface water constituents such as natural organic matter (NOM) and its fractions is observed: the synergistic effect resulted in a transmembrane pressure (TMP) increase always higher than the sum of the TMP increase due to the filtration of $\mathrm{nC}_{60}$ in ultrapure water and the TMP increase due to the surface water without $\mathrm{nC}_{60}$.
\end{abstract}




\section{Chapter 3}

\subsection{Introduction}

Given the growth of the nanotechnology industry in the past 20 years (Benn, Westerhoff, \& Herckes, 2011; Murayama, Tomonoh, Alford, \& Karpuk, 2004; Osawa, 2002) and the accompanying increase in the amount of engineered nanomaterials and nanoparticles (eNPs) that enter the environment (Gottschalk, Sun, \& Nowack, 2013), environmental and human health reasons require the investigation and assessment of the behaviour and toxicity of these new potential pollutants in natural and engineered environments.

Buckminsterfullerene $\left(\mathrm{C}_{60}\right)$ (Kroto, Heath, O’Brien, Curl, \& Smalley, 1985) is one of the most widely used eNPs (Baena, Gallego, Valca, \& Division, 2002; Osawa, 2002) due to its particular physical and chemical properties (Guldi \& Prato, 2000) i.e. heat resistance, conductivity and electron-acceptor capability. This explains its wide spread use in different applications, e.g. cosmetics (Reisch, 2009), biological and medical applications (Bakry et al., 2007; Jensen, Wilson, \& Schuster, 1996) and plastic solar cells (Brabec, Sariciftci, \& Hummelen, 2001). $\mathrm{C}_{60}$ can form nano-sized colloidal aggregates in water (usually and here as well referred to as $\mathrm{nC}_{60}$ ) (Deguchi, Alargova, \& Tsujii, 2001) and can therefore potentially end up in aquatic compartments when released to the environment.

The presence of $\mathrm{nC}_{60}$ in aquatic environment (Farré et al., 2010) and consequently in sources for drinking water production (Gottschalk et al., 2013) poses several challenges. Firstly, $\mathrm{nC}_{60}$ has been found toxic to several organisms (bacteria fish and human cell lines (S.-R. Chae et al., 2009; Lyon, Adams, Falkner, \& Alvarezt, 2006; Sayes et al., 2005; Song et al., 2012)) and can function as a carrier for other pollutants such as adsorbed hydrophobic organic contaminants or heavy metals (Baun, Sørensen, Rasmussen, Hartmann, \& Koch, 2008; Hofmann \& von der Kammer, 2009; Musee, 2011; Navarro et al., 2008; Stone et al., 2010; Xie, Xu, Guo, \& Li, 2008; Yang, Zhu, \& Xing, 2006; Lizhu Zhang et al., 2014). Therefore, its removal is mandatory for safe drinking water production. Secondly, $\mathrm{nC}_{60}$ will interact with water treatment systems affecting their performance, for instance causing fouling in microfiltration processes (Floris, Nijmeijer, \& Cornelissen, 2016; Henry \& Brant, 2012).

Both the removal of eNPs using microfiltration membranes and the fouling of microfiltration membranes when filtering these eNPs are governed by complex interactions between the 
membrane and the eNPs, which is made even more complex due to the additional contribution of the natural background of water constituents. Particularly natural organic matter (NOM, a complex mixture composed of different organic materials (Sillanpää, 2015)) and divalent cations such as calcium and magnesium play a critical role in both eNP stability (K.L. Chen, Smith, Ball, \& Fairbrother, 2010) and membrane fouling (Hong \& Elimelech, 1997; Huang et al., 2007; Q. Li \& Elimelech, 2006).

Investigations on the effects of NOM on the aggregation of $\mathrm{nC}_{60}$ indicate that the presence of NOM results in a diminished aggregation of the eNPs, thus increasing their colloidal stability (Grillo, Rosa, \& Fraceto, 2015; W. Zhang, Rattanaudompol, Li, \& Bouchard, 2013). Due to the intrinsic negative charges of NOM, their adsorption onto colloidal surfaces imparts more negative charges to the surface (Philippe \& Schaumann, 2014). NOM with a high average molar mass, low polarity and hydrophobic chains showed a good interaction with $\mathrm{nC}_{60}$, and increased the $\mathrm{nC}_{60}$ stability (Mashayekhi, Ghosh, Du, \& Xing, 2012). High molecular weight fractions of NOM such as large humic-like materials have been identified as key components for stabilizing $\mathrm{nC}_{60}$ in monovalent electrolyte solutions (Shen, Yin, Booth, \& Liu, 2014; W. Zhang et al., 2013). Electrostatic repulsion among $\mathrm{nC}_{60}$ was found positively correlated with the concentration of humic acid in the solution (Lu-qing Zhang, Zhang, Lin, Yang, \& Lin, 2014). The stabilization effect of $\mathrm{NOM}$ on $\mathrm{nC}_{60}$ might be achieved also through the reduced surface hydrophobicity (S. Chae et al., 2015).

Whilst humic substances tend to decrease aggregation and deposition of $\mathrm{nC}_{60}$, the presence of multivalent cations induces aggregation, thus leading to flocculation (Philippe \& Schaumann, 2014). Also the presence of electrolytes influences the size of the $\mathrm{nC}_{60}$ aggregates, because electrical double layer compression enhances destabilization and aggregation (Duan \& Gregory, 2003) of colloidal particles in water. The presence of positively charged ions in water screens the negative surface charge of the $\mathrm{nC}_{60}$ resulting in a more favorable condition for $\mathrm{nC}_{60}$ aggregation. The aggregation behavior of $\mathrm{nC}_{60}$ in the presence of $\mathrm{NaCl}, \mathrm{MgCl}_{2}$, and $\mathrm{CaCl}_{2}$ was found to be consistent with the classic DerjaguinLandau-Verwey- Overbeek (DLVO) theory of colloidal stability (Kai Loon Chen \& Elimelech, 2007).

The simultaneous presence of humic acids and $\mathrm{CaCl}_{2}$ in natural water resulted in an increased $\mathrm{nC}_{60}$ stability at low $\mathrm{CaCl}_{2}$ concentrations, while enhanced aggregation occurred at high 


\section{Chapter 3}

( $>10 \mathrm{mM}) \mathrm{CaCl}_{2}$ concentrations. Enhanced aggregation was attributed to intermolecular bridging by calcium of humic acid-coated $\mathrm{nC}_{60}$ (K.L. Chen et al., 2010; Shen et al., 2014; Luqing Zhang et al., 2014).

The composition of the water not only has an influence on the stability of $\mathrm{nC}_{60}$, the composition and the characteristics of the water also determine to a large extent membrane fouling (Lee, Amy, Croué, \& Buisson, 2004). Previous work has been done to understand the role of the amount, composition and properties of NOM and divalent cations on membrane fouling in drinking water treatment processes. NOM plays a significant role in fouling of microfiltration membranes even though it is retained only to a small extent (Carroll, King, Gray, Bolto, \& Booker, 2000; Fan, Harris, Roddick, \& Booker, 2001). The major contribution to fouling is attributed to the NOM fraction comprising of biopolymers and small, neutral, hydrophilic compounds (Kimura, Tanaka, \& Watanabe, 2014). Meanwhile the NOM fractions comprising of humic and fulvic acids have only a minor contribution to microfiltration membrane fouling (Carroll et al., 2000). Shang et al. (2015) found that, depending on the size of the membrane pores, the adsorption of NOM foulants can generate internal fouling. Based on experimental measurements, Yamamura et al. (2007) proposed a two-step fouling model where hydrophobic small molecular weight (humic-like) components are adsorbed first on the membrane surface thereby narrowing the size of the membrane pores, followed by larger hydrophilic molecular weight (carbohydrate-like) compounds that plug the narrowed pores of the membrane. Furthermore, the presence of calcium and its interactions with NOM played a major role in microfiltration fouling of surface waters (Schafer, 2000). Divalent cations reduce humic acid interchain repulsion resulting in the formation of a more densely packed fouling layer on the membrane surface (Hong \& Elimelech, 1997).

The studies mentioned above focused on either the interaction of divalent cations and NOM (fractions) or solely on membrane fouling or $\mathrm{nC}_{60}$ stability, but the combined effect of multiple parameters, i.e. a comprehensive study combining the influence of divalent cations, $\mathrm{NOM}$ and its fractions on $\mathrm{nC}_{60}$ removal and membrane fouling in microfiltration of natural surface water is still lacking, although the effect of divalent ions and NOM can affect the membrane fouling and as such may have a negative impact on the rejection of $\mathrm{nC}_{60}$, resulting in $\mathrm{nC}_{60}$ in the permeate, impairing drinking water quality. A study on the effect of such a 
multicomponent mixture using real surface water is essential to guarantee safe drinking water on the longer run.

In the present study, we do investigate the microfiltration behavior of $\mathrm{nC}_{60}$ dispersed in real surface water and focus on the elucidation of the role of NOM and divalent cations on (i) the removal of $\mathrm{nC}_{60}$ in semi dead-end hollow fiber microfiltration and (ii) membrane fouling during natural surface water microfiltration in the presence of $\mathrm{nC}_{60}$.

To identify the role of NOM and calcium (apart or in combination) on $\mathrm{nC}_{60}$ removal and microfiltration membrane fouling, we used both pre-filtered and pre-treated natural surface water. Filtration experiments with commercially available polymer membranes were conducted, including a regular backwash cleaning procedure with multiple cycles. Removal degree and removal mechanisms of fullerene $\mathrm{nC}_{60}$ were evaluated by analyzing transmembrane pressure (TMP) changes during filtration, evaluating the development of reversible and irreversible fouling and performing membrane autopsies with electron scanning microscopy observations.

\subsection{Materials and methods}

\subsubsection{Reagents and Chemicals}

Fullerene- $\mathrm{C}_{60}$ (purity >99.5\%) was obtained from Sigma Aldrich (Steinheim, Germany). Toluene was purchased from Mallinckrodt Baker B.V. (Deventer, the Netherlands).

Lewatit VPOC 1071 type (Lanxess, Germany) heterodisperse anion exchange gel type resins were used for NOM removal. The anion exchange (AIEX) resins were based on a polyacrylamide backbone functionalized with quaternary amine (type I) groups. The average AIEX resin size was $0.55 \mathrm{~mm}$ and the resin density was $1.09 \mathrm{~g} / \mathrm{ml}$. Lewatit MonoPlus S 108 (Lanxess, Germany) monodisperse cation exchange resins were used for $\mathrm{Ca}^{2+}(\mathrm{aq})$ and $\mathrm{Mg}^{2+}(\mathrm{aq})$ removal. The cation exchange (CIEX) resins were based on a styrene-divinyl benzene copolymer. The average CIEX resin size was $0.65 \mathrm{~mm}$ and the resin density was $0.79 \mathrm{~g} / \mathrm{ml}$. Before use, both AIEX and CIEX resins were pre-rinsed and regenerated according to a procedure described elsewhere (Cornelissen et al, 2010). Briefly, $500 \mathrm{~g}$ of 


\section{Chapter 3}

resin was rinsed for $12 \mathrm{~h}$ in 12.51 tap water. Afterwards the resin was removed from the tap water and then mixed in $15 \mathrm{lof} \mathrm{NaCl} 10 \%$ w/w solution during $2 \mathrm{~h}$ for regeneration. The four different pre-treated water types were obtained after IEX treatment using the above described IEX resins using the same surface water batch collected from the Lek canal (Nieuwegein, the Netherlands) prior to the Amsterdam Water Supply Dunes (AWDs) uptake.

\subsubsection{Preparation and characterization of $\mathrm{nC}_{60}$ dispersions}

Stable aqueous $\mathrm{nC}_{60}$ suspensions were prepared using a solvent exchange/sonication procedure (Kai Loon Chen \& Elimelech, 2007). Briefly, $50 \mathrm{mg}$ of $\mathrm{C}_{60}$ fullerene powder was added to $100 \mathrm{ml}$ toluene and it was stirred for at least $12 \mathrm{~h}$ to achieve complete dissolution of the fullerenes. The $\mathrm{C}_{60}$ solution was added to $350 \mathrm{ml}$ ultrapure water $(18.2 \mathrm{M} \Omega \cdot \mathrm{cm})$ in a 600 $\mathrm{ml}$ beaker. Toluene was evaporated in a sonication bath (Branson) at an energy intensity of $125 \mathrm{~W}$. Ultrapure water was regularly added each hour to compensate for the volume loss due to toluene evaporation and to avoid fullerene deposition. The resulting colloidal dispersion was finally filtered through a 0.45 and a $0.22 \mu \mathrm{m}$ cellulose acetate vacuum filter system (Corning Amsterdam, the Netherlands). This procedure was repeated 6 times resulting in $\mathrm{nC}_{60}$ stock concentrations of $15-20 \mathrm{mg} / \mathrm{l}$. The obtained stock was diluted afterwards in the four different water types to reach a final concentration of $1 \mathrm{mg} / \mathrm{l}$.

Characterization of the $\mathrm{nC}_{60}$ stock was performed with a set of different analytical techniques. The presence of colloidal dispersions was measured by UV-VIS spectrophotometry. The $\mathrm{nC}_{60}$ UV/VIS absorption spectrum of the stock displayed two typical peaks at 250 and $360 \mathrm{~nm}$ (not shown here), as was observed before (Jung, Kim, Kim, \& Kim, 2013). Concentrations of $\mathrm{nC}_{60}$ were measured after liquid-liquid extraction with toluene (Kolkman et al., 2013) by using normal-phase liquid chromatography coupled to high-resolution mass spectrometry and UV spectrophotometry (LC-MS-UV). Due to the required concentration range two approaches were used: (i) concentrations ranging from 0.1-128 $\mu \mathrm{g} / \mathrm{l}$ were quantified by using the accurate molecular ion mass to charge ratio $(\mathrm{m} / \mathrm{z})$ of $\mathrm{C}_{60}(720.00055 \mathrm{~m} / \mathrm{z})$ and (ii) concentrations $>128 \mu \mathrm{g} / \mathrm{l}$ were determined by UV spectrophotometry (at $335 \mathrm{~nm}$ ).

The $\mathrm{nC}_{60}$ size distributions in the 4 different treated surface waters (directly after dosing $\mathrm{nC}_{60}$ in the surface water) were determined by dynamic light scattering (DLS). Measurements 
were performed with a Zetasizer Nano-ZS (Malvern Instruments, Worcestershire, UK). Samples were measured at $25^{\circ} \mathrm{C}$, in triplicate. Zeta potential measurements were carried out using the same equipment to evaluate the surface charge and zeta potential of the $\mathrm{nC}_{60}$ (samples were measured 9 times per measuring point) in the 4 different treated surface waters (directly after dosing $\mathrm{nC}_{60}$ in the surface water). The average particle size of the $\mathrm{nC}_{60}$ in ultrapure water was determined by dynamic light scattering $(146 \mathrm{~nm})$, nanoparticle tracking analysis (134 nm) and analytical ultra-centrifugation (106 nm) (Floris et al., 2016). The zeta potential of $\mathrm{nC}_{60}$ in ultrapure water, measured in previous work, was $-42.8 \mathrm{mV} \pm 1.33$ (Floris et al., 2016). This high zeta potential was also reported in several previous studies (Brant, Lecoanet, Hotze, \& Wiesner, 2005; Kai Loon Chen \& Elimelech, 2009) and indicates high stability of the dispersion.

\subsubsection{Preparation and characterization of water type backgrounds}

To understand the role of the water quality parameters on the removal of $\mathrm{nC}_{60}$ by microfiltration, experiments were performed with $\mathrm{nC}_{60}$ dispersed in waters containing different amounts and compositions of NOM and in the presence or absence of divalent cations. The investigated water types were: (i) pre-filtered surface water (PF), (ii) pre-filtered and anion exchange treated surface water (AIEX), (iii) pre-filtered and cation exchange treated surface water (CIEX) and (iv) pre-filtered and both anion and cation exchange treated surface water (ACIEX). Filtration experiments of $\mathrm{nC}_{60}$ dispersed in ultrapure water (Millipore, Bedford, MA) were also performed as a reference. Pre-filtered surface water was obtained by filtering the raw water subsequently through a 0.45 and a $0.22 \mu \mathrm{m}$ cellulose acetate vacuum filter system (Corning Amsterdam, the Netherlands) to reduce turbidity and remove suspended solids present in the water. Anion and cation exchange treated surface water were obtained by stirring 251 of such pre-filtered surface water with $500 \mathrm{~g}$ of resins for $24 \mathrm{~h}$. The four water types were stored until use (maximum 2 weeks) in the dark at $4{ }^{\circ} \mathrm{C}$ to minimize changes in the water composition before the experiments. The water compositions of the pre-filtered surface water and the anion, cation and anion/cation exchange treated water were determined by the laboratory of the water company Vitens (the 


\section{Chapter 3}

Netherlands) with an in-house method VL-W-ACO1/02, VL-W-ME04, VL-T-AL35 and VLW-00O2 according to NEN-EN-ISO/IEC 17025 NEN-EN-ISO 9001:2008, OHSAS 18001:2007 and ISO 14001:2004 standards.

\subsubsection{Membrane and membrane characterization}

Commercially available hollow fiber membranes made of a blend of polyethersulfone/ polyvinylpyrrolidone were supplied by Pentair X-Flow (Enschede, the Netherlands). According to the manufacturer the membranes were moderately hydrophilic with an average membrane pore size of $200 \mathrm{~nm}$, which was confirmed by porometry measurements (Floris et al., 2013; Trzaskus, de Vos, Kemperman, \& Nijmeijer, 2015). Lab-scale membrane modules were prepared by potting one membrane fiber using a two-component epoxy resin (Poliservice, Amsterdam, the Netherlands) in a transparent plastic polyvinylchloride tube of 23 $\mathrm{cm}$ in length and $1 \mathrm{~cm}$ in diameter to obtain a membrane filtration area of $10 \mathrm{~cm}^{2}$. The membrane housing contained a feed inlet connection (also the backwash outlet connection), a permeate outlet connection (also the backwash inlet connection) and two manually adjustable valves to release air bubbles that can form inside the fibers and/or in the membrane housing. The zeta potential of the inner surface of the membranes was $-23 \mathrm{mV}$ measured at pH 8 using a SurPASS electrokinetic analyser (Trzaskus et al., 2015).

\subsubsection{Filtration set-up and procedure}

Pure water flux (volumetric flow rate per unit area of membrane) and $\mathrm{nC}_{60}$ filtration measurements were performed with a lab-scale pilot (Fig. 2-2). A constant feed flow of 0.5 $1 / \mathrm{h}$ was provided by a pulsation free neMESYS syringe pump (Cetoni GmbH, Germany) connected to the feed vessel. A pressure sensor in the feed line measured the feed pressure every 5 seconds and an average transmembrane pressure (TMP) (n=3) was calculated and logged every 15 seconds. A pressurized backwash vessel (3 bars) containing fresh ultra-pure water combined with a flow controller was connected to a permeate line for the backwash sequence. A 20 seconds backwash occurred automatically every $20 \mathrm{~min}$, which is a cleaning frequency relevant for membrane processes in drinking water treatment (Shi, Tal, Hankins, $\&$ Gitis, 2014). The total filtration duration was 2 hours including a series of 6 filtration 
cycles and 6 backwash sequences. All these experiments were performed at a constant temperature of $20{ }^{\circ} \mathrm{C}$. Feed samples were collected before the experiments and permeate samples were collected during filtration cycle one, two, four and six to evaluate the $\mathrm{nC}_{60}$ removal at different filtration stages. After the last backwash, the membranes were flushed with ultra-pure water to evaluate the membrane permeability recovery after $\mathrm{nC}_{60}$ filtration, from which the irreversible fouling contribution was calculated. This is an indirect indication of the amount of particles and other compounds that foul or adsorb onto the membrane and remain on the membrane after the flushing procedure. The flushing procedure consisted of 2 filtration cycles of ultrapure water at a constant feed flow $(0.5 \mathrm{l} / \mathrm{h}$ for $20 \mathrm{~min})$ followed by the backwash sequence $(2 \mathrm{l} / \mathrm{h}$ for $20 \mathrm{sec})$. A schematic representation of the filtration protocol is given in Figure 3-1.

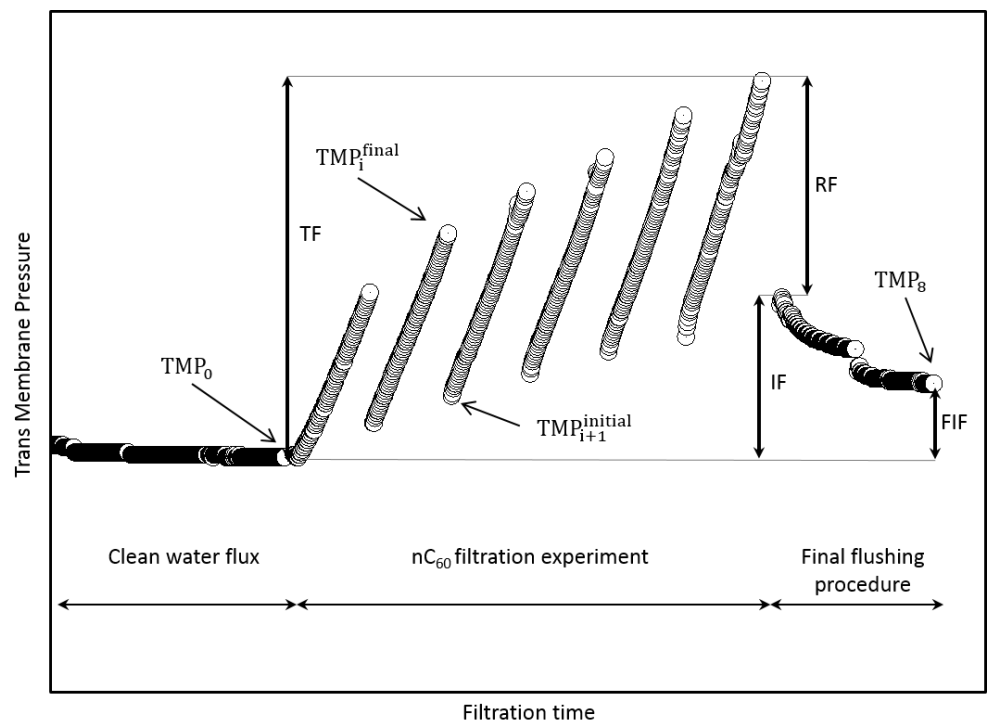

Figure 3-1: Filtration protocol and fouling parameters as obtained from the TMP increase in time, where TF is the total fouling, $R F$ is the reversible fouling, IF is the irreversible fouling, FIF is the final irreversible fouling after the final flushing procedure. Where $T M P_{i}^{\text {final }}$ is the TMP at the end of filtration cycle i before the backwash cleaning procedure, $T M P_{i+1}^{\text {initial }}$ is the TMP at the beginning of filtration cycle $i+1$ after the backwash cleaning procedure and $T M P_{0}$ is the TMP at the beginning of the experiment, immediately after the clean water flux measurement. 


\section{Chapter 3}

\subsubsection{Data handling}

The removal efficiency ( $\mathrm{R}[\%])$ of $\mathrm{nC}_{60}$ was evaluated as the $\mathrm{nC}_{60}$ rejection calculated from Equation 1:

$R=\left(1-\frac{C_{p}}{C_{f}}\right) \times 100$

Where $C_{p}$ is the permeate concentration and $C_{f}$ is the feed concentration $[\mathrm{mg} / \mathrm{l}]$.

To assess the type of fouling occurring during the filtration of $\mathrm{nC}_{60}$ by the low-pressure membranes, we analysed the evolution of measurable process parameters in time as follow:

Total Fouling $\left(\mathrm{TF}_{\mathrm{i}}\right)$ at the generic cycle number $\mathrm{i}$, is the maximum increase in TMP during filtration, calculated according to Equation 2:

$T F_{i}=T M P_{i}^{\text {final }}-T M P_{0}$

Where $T M P_{i}^{\text {final }}$ is the TMP at the end of filtration cycle $i$ and before the backwash cleaning procedure and $T M P_{0}$ is the TMP at the beginning of the experiment, immediately after the clean water flux measurement.

Irreversible Fouling (IF) is the amount of foulant that cannot be removed by the backwash cleaning procedure only and accumulated in/on the membrane compromising the TMP. The IF at the generic cycle number i, is calculated according Equation 3:

$I F_{i}=T M P_{i+1}^{\text {initial }}-T M P_{0}$

In constant flux filtration, TMP increases linearly with time when an incompressible cake layer is formed (Chellam \& $\mathrm{Xu}, 2006$ ). In contrast, when the cake layer deposition is compressible, the pressure profile is concave-upward (Chellam \& Cogan, 2011). Additional analysis of the pressure profiles and the corresponding change of the slope (dTMP/dt) in time (or of the volume filtered) was done to obtain more insight in the removal efficiency and the fouling mechanism. 


\subsection{Results and discussion}

\subsubsection{Water quality parameters}

The water compositions of the pre-filtered surface water and anion, cation and anion/cation exchange treated water are given in Table 3-1.

Table 3-1: Water quality parameters of the 4 water types.

\begin{tabular}{|c|c|c|c|c|}
\hline & \multicolumn{4}{|c|}{ Water types } \\
\hline & $\mathbf{P F}$ & AIEX & CIEX & ACIEX \\
\hline Turbidity (NTU) & 0.2 & 0.2 & 0.2 & 0.2 \\
\hline Suspended solid [mg/l] & $<1$ & $<1$ & $<1$ & $<1$ \\
\hline Conductivity $(\mu \mathrm{S} / \mathrm{cm})$ & 699 & 1560 & 1035 & 2210 \\
\hline $\mathrm{pH}$ & 8.2 & 7.8 & 8.3 & 7.9 \\
\hline Zeta potential $(\mathrm{mV})$ & -10.1 & -6.87 & -7.93 & -13.9 \\
\hline $\mathrm{DOC}(\mathrm{mg} / \mathrm{l})$ & 2.9 & 0.7 & 3.2 & 0.8 \\
\hline Total hardness (mmol/l) & 2.4 & 2.3 & $<0.02$ & $<0.02$ \\
\hline $\mathrm{Ca}^{2+}(\mathrm{mg} / \mathrm{l})$ & 76.0 & 74.2 & $<0.5^{\mathrm{a}}$ & $<0.5^{\mathrm{a}}$ \\
\hline $\mathrm{Mg}^{2+}(\mathrm{mg} / \mathrm{l})$ & 11.8 & 11.1 & $<0.1^{\mathrm{a}}$ & $<0.1^{\mathrm{a}}$ \\
\hline $\mathrm{K}^{+}(\mathrm{mg} / \mathrm{l})$ & 3.9 & 3.8 & 0.3 & 0.4 \\
\hline $\mathrm{Na}^{+}(\mathrm{mg} / \mathrm{l})$ & 46.2 & 207.0 & 198 & 539.0 \\
\hline $\mathrm{Cl}^{-}(\mathrm{mg} / \mathrm{l})$ & 86.0 & 380.0 & 160 & 550.0 \\
\hline $\mathrm{NO}_{3}^{-}(\mathrm{mg} / \mathrm{l})$ & 13.7 & 2.6 & - & 4.0 \\
\hline $\mathrm{SO}_{4}^{-}(\mathrm{mg} / \mathrm{l})$ & 55.0 & $<2$ & 56 & $<2$ \\
\hline $\mathrm{HCO}_{3}^{-}(\mathrm{mg} / \mathrm{l})$ & 185.0 & 78.0 & 184 & 84.0 \\
\hline
\end{tabular}

${ }^{\text {a }}$ Removal $>99 \%$ from PF water; *not measured.

All waters showed a low content of suspended solid ( $<1 \mathrm{mg} / \mathrm{l})$ and a low turbidity $(\sim 0.2$ FTE $)$ as result of the pre-filtration treatment through the 0.45 and $0.22 \mu \mathrm{m}$ filters. AIEX treatment reduced the NOM content measured as DOC with $\sim 70 \%$, which has been shown elsewhere to be mainly due to the removal of the humic substance fraction of the total NOM (Cornelissen et al., 2010). Based on Cornelissen et al. we assumed that the remaining NOM 


\section{Chapter 3}

fraction was mainly composed of neutrals, biopolymers and building blocks (i.e. hydrolysates of humic acids) (Cornelissen et al., 2010; Sillanpää, 2015). CIEX treatment almost completely removed the present divalent cations (>99\% removal).

After both anion and cation exchange treatment, the waters showed an increase in conductivity. The increased value of water conductivity is due to the increased concentration of $\mathrm{Na}^{+}$and $\mathrm{Cl}^{-}$released from the resins, as consequence of the exchange process with NOM and $\mathrm{Ca}^{2+}$ and $\mathrm{Mg}^{2+}$. This is also visible in Table 1, which shows higher concentrations for $\mathrm{Na}^{+}$and $\mathrm{Cl}^{-}$in all treated waters compared to pre-filtered water (PF). The dissolved salt content can potentially affect the $\mathrm{nC}_{60}$ removal efficiency. However, it is also proven that destabilization of eNPs in water increases with increasing ion valence, due to higher compression of the eNPs double layer (Lizhu Zhang et al., 2014). In this study we removed the amount of divalent cations $\left(\mathrm{Ca}^{2+}\right.$ and $\left.\mathrm{Mg}^{2+}\right)$ since these are the fractions of salinity in water that control the $\mathrm{nC}_{60}$ stability (Kai Loon Chen \& Elimelech, 2009) and consequently its removal efficiency. 


\subsection{2 $\mathrm{nC}_{60}$ size and zeta potential}

The zeta potential and the average particle size of the $\mathrm{nC}_{60}$ dispersed in the 4 different treated surface waters are reported in Figure 3-2.
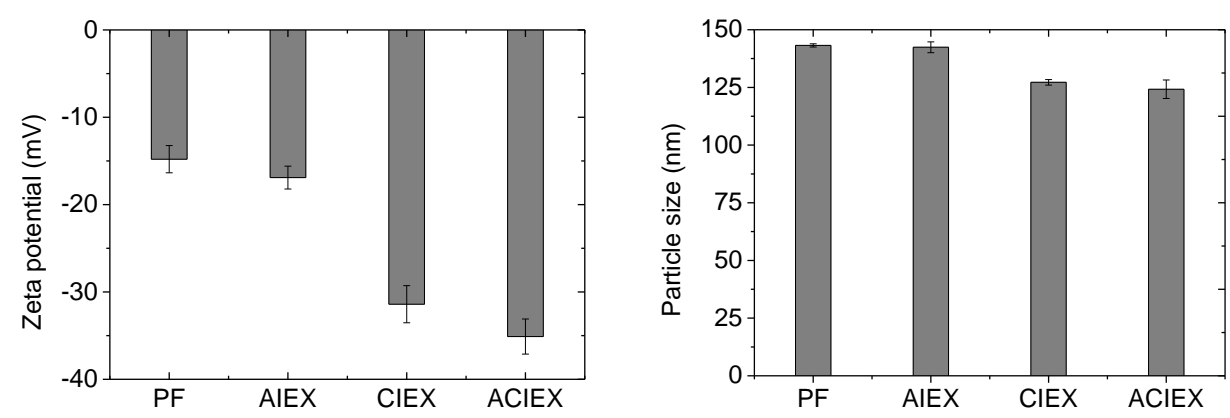

Figure 3-2: Zeta potential and average particle size of $n C_{60}$ dispersed in the 4 different treated surface waters $\left(25^{\circ} \mathrm{C}\right.$ and $\left.\mathrm{pH} 8 \pm 0.2\right)$.

When dispersed in natural water, $\mathrm{nC}_{60}$ is subject to stabilization effects by $\mathrm{NOM}$ and destabilization effects by cations present in the water. Dispersed particles are destabilized when their electrostatic surface charge is neutralized by positively charged ions (Hotze, Phenrat, \& Lowry, 2010). On the other hand the stability will increase as a result of the additional negative charge imparted by $\mathrm{NOM}$ adsorbed onto the $\mathrm{nC}_{60}$ (Kai Loon Chen \& Elimelech, 2007; Hyung \& Kim, 2009). The resultant of these two competitive effects can be analysed by zeta potential measurements. Colloids with a zeta potential more negative than $-30 \mathrm{mV}$ are considered to have strong electrostatic repulsions and tend to remain dispersed, while a value of the zeta potential less negative than $-30 \mathrm{mV}$, makes them prone to aggregation and destabilization due to only weak electrostatic repulsions between the particles (Lin, Liu, Yang, Xing, \& Wu, 2010; Lu-qing Zhang et al., 2014).

From our zeta potential measurements significant differences can be observed between water with $\mathrm{Ca}^{2+}$ and $\mathrm{Mg}^{2+}$ cations (PF and AIEX) and without $\mathrm{Ca}^{2+}$ and $\mathrm{Mg}^{2+}$ cations (CIEX and ACIEX). Without cations in the water, the value of the zeta potential is slightly higher than $30 \mathrm{mV}$ (CIEX $-31.4 \pm 2.13 \mathrm{mV}$ and ACIEX -35.1 $\pm 2.01 \mathrm{mV}$ ). Therefore, these two dispersions can most probably be considered stable. In contrast, when $\mathrm{Ca}^{2+}$ and $\mathrm{Mg}^{2+}$ are 


\section{Chapter 3}

present in the water, these ions screen the $\mathrm{nC}_{60}$ surface charge and the zeta potential measured is less than $-30 \mathrm{mV}(\mathrm{PF}-14.8 \pm 1.56 \mathrm{mV}$ and AIEX $-16.9 \pm 1.31 \mathrm{mV})$. This results in incipient instability of the dispersions (Nguyen \& Asmatulu, 2013). The $\mathrm{nC}_{60}$ particles show comparable sizes in both PF $(143.2 \pm 0.7 \mathrm{~nm})$ and AIEX $(142.2 \pm 2.3 \mathrm{~nm})$ treated water, which is also in agreement with the $\mathrm{nC}_{60}$ size reported in ultrapure water $((146 \pm 1.9 \mathrm{~nm}$ (Floris et al., 2016)). This suggests that, despite the potential instability due to charge screening by $\mathrm{Ca}^{2+}$ and $\mathrm{Mg}^{2+}$, agglomeration of the particles did not happen before the filtration experiments. The particle size in the absence of divalent cations (CIEX and ACIEX) is slightly smaller and measures approximately $127 \pm 1 \mathrm{~nm}$ and $124 \pm 4 \mathrm{~nm}$. In the absence of divalent cations (CIEX and ACIEX) particle sizes are also smaller than the $\mathrm{nC}_{60}$ particle size in ultrapure water. The smaller size of $\mathrm{nC}_{60}$ treated surface water does not depend on the presence of negatively charged NOM since both CIEX and ACIEX water show comparable particle size. Therefore, we hypothesize that this decrease in particle size is related to the interaction of $\mathrm{nC}_{60}$ with the neutral and positively charged fractions of NOM. However, regardless the origin of the smaller $\mathrm{nC}_{60}$ size in the absence of divalent cations (CIEX and ACIEX), the ratio of $\mathrm{nC}_{60}$ size to mean membrane pore size $(0.7 / 0.6)$ does not change significantly for the 4 water types analysed in this work.

\subsubsection{Filtration behaviour of $\mathrm{nC}_{60}$ in different water backgrounds}

Figure 3-3 shows the TMP increase during microfiltration of the 4 different water types with the addition of $1 \mathrm{mg} / \mathrm{nC}_{60}$ (black symbols). In the graphs, also the TMP increase during microfiltration of (i) (treated) surface water without $\mathrm{nC}_{60}$ (PF, CIEX, AIEX or ACIEX) (dark grey) and (ii) a $1 \mathrm{mg} / \mathrm{lnC}_{60}$ dispersion in ultrapure water is reported as references (light grey symbols). Reference filtration experiments of $\mathrm{nC}_{60}$ in ultrapure water and of the 4 different water backgrounds without $\mathrm{nC}_{60}$ were performed to determine synergistic effects due to interactions between the water constituents and $\mathrm{nC}_{60}$. 

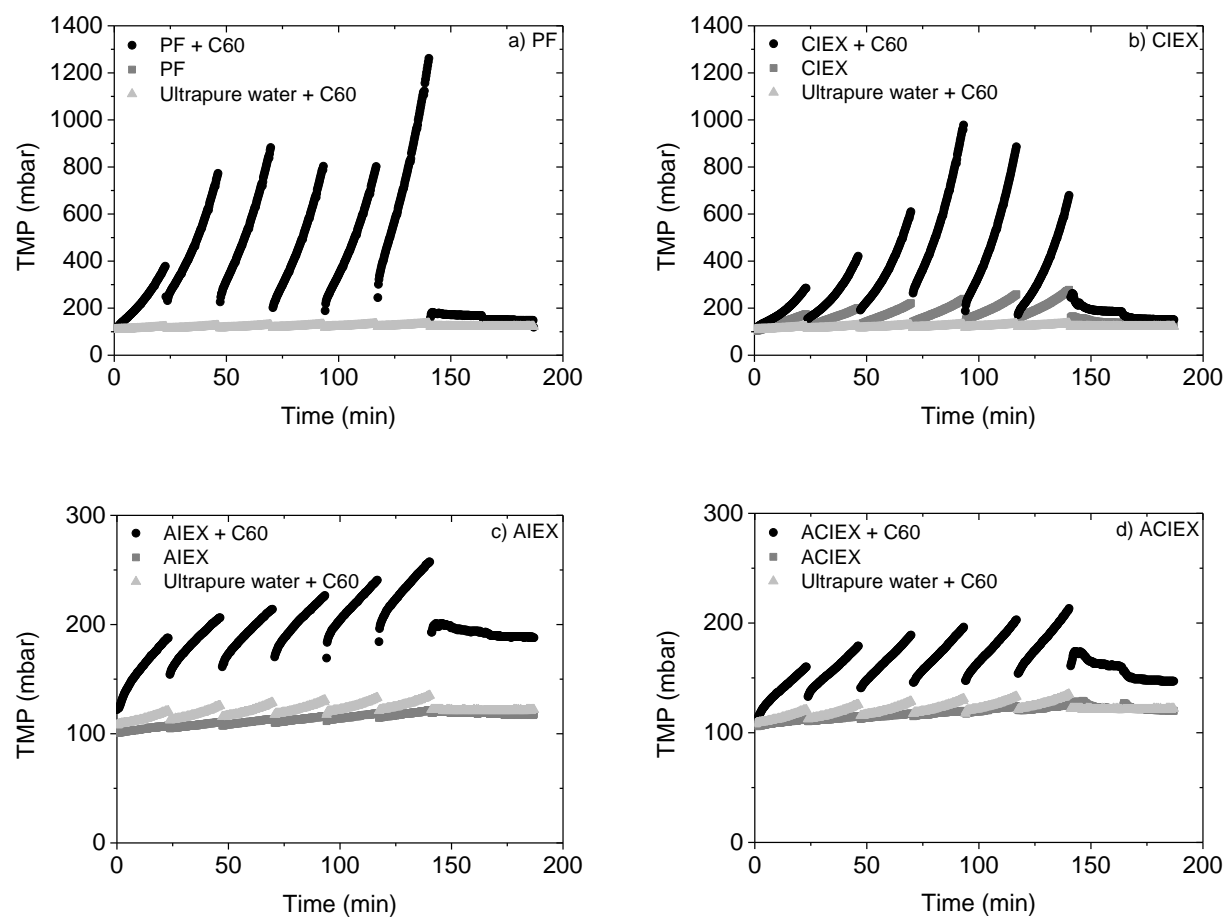

Figure 3-3: TMP versus time for the filtration experiments of $n C_{60}$ in the four different water type backgrounds (black symbols): a) pre-filtered water, b) CIEX treated water, c) AIEX treated water and d) AIEX and CIEX treated water. Corresponding experiments for the four different water types without $n C_{60}$ (dark grey symbols) and for $n C_{60}$ in ultrapure water (light grey symbols) are also shown as references. (Mind the different scales of the $Y$-axis).

Filtration of $1 \mathrm{mg} / \mathrm{l}$ of $\mathrm{nC}_{60}$ dispersed in ultrapure water resulted in a moderate TMP increase of 0.027 mbar over 6 filtration cycles (Figure 3-3 light grey symbols). The TMP increase in time is due to pore blocking and cake layer deposition of the $\mathrm{nC}_{60}$ on the membrane surface (Floris et al., 2016). The TMP increase is only partially reduced by the backwash procedure with an irreversible fouling contribution of about $57 \%$ of the total fouling in the case of $\mathrm{nC}_{60}$ in ultrapure water.

Filtration of $1 \mathrm{mg} / \mathrm{l}$ of $\mathrm{nC}_{60}$ dispersed in surface water resulted in different TMP increases and fouling behavior depending on the NOM fraction and on the amount of $\mathrm{Ca}^{2+}$ and $\mathrm{Mg}^{2+}$ in the surface water used as background (Figure 3-3, black circles). Filtration of $\mathrm{nC}_{60}$ in waters containing the complete NOM fraction (PF and CIEX treated water) results in the 


\section{Chapter 3}

highest increase of the TMP (up to 1000 and 1200 mbar) over the 6 filtration cycles (Figure $3-3 a$ and 3-3b). The TMP increase is significantly reduced (in the range of $200-250$ mbar) when the negatively charged NOM fractions are removed (AIEX and ACIEX treated waters, Figure 3-3c and 3-3d), as a consequence of the lower amount of NOM (about $75 \%$ removal due to anion exchange treatment), which is thus responsible for severe the TMP increase.

The presence (PF and AIEX waters) or absence (CIEX and ACIEX waters) of $\mathrm{Ca}^{2+}$ and $\mathrm{Mg}^{2+}$ does not significantly impact the TMP increase within the 6 filtration cycles when the contribution of the NOM fraction is excluded. Consequently, the reduced stability of $\mathrm{nC}_{60}$ when bivalent cations are present (PF and AIEX) does not seem to affect the TMP increase during the filtration experiments.

Overall, despite differences in the amount of NOM and concentrations of $\mathrm{Ca}^{2+}$ and $\mathrm{Mg}^{2+}$ present in the different water backgrounds, in all cases, a strong synergistic effect between the $\mathrm{nC}_{60}$, the cations and $\mathrm{NOM}$ during filtration of the different water types containing $\mathrm{nC}_{60}$ is observed. The TMP increase is always higher than the sum of the TMP increase due to the filtration of $\mathrm{nC}_{60}$ in ultrapure water and the TMP increase due to the surface water without $\mathrm{nC}_{60}$. This synergistic effect is especially dominant when the negatively charged NOM fraction is present in the water (Figure 3-3a and 3-3b) and less dependent on the presence of divalent cations.

It is hypothesized that this synergetic effect is the result of different structural properties of the cake layer formed on top of the membrane surface, especially in the presence of negatively charged NOM. When only NOM is present in the water, the deposition layer formed on top of the membrane exhibits a certain cake porosity. During filtration of water containing simultaneously NOM and eNPs, the eNPs may fill the void spaces of the NOM deposited on the membrane surface thus leading to a lower cake porosity and therefore a higher filtration resistance. In this scenario, it seems reasonable to assume a stronger synergetic effect when the negatively charged NOM fraction is present in the water. Moreover it was previously shown (Jermann, Pronk, \& Boller, 2008) that ultrafiltration of NOM (a mixture of humic acid, alginates (polysaccharides)) and inorganic particles (kaolinite with particle size $450 \mathrm{~nm}$ ) resulted in a synergistic fouling effect due to particle stabilization by NOM and sterical interferences between the two foulants. Although the 
particle size in our experiments is different and considerably smaller, similar effects in our filtration experiments are envisaged to take place.

Figure 3-4 shows the total and the irreversible fouling (both expressed in TMP increase) over the six filtration cycles of $\mathrm{nC}_{60}$ dispersed in the 4 water backgrounds investigated. The total and the irreversible fouling of the surface waters without $\mathrm{nC}_{60}$ is reported in the Supporting Information (Figure S1).
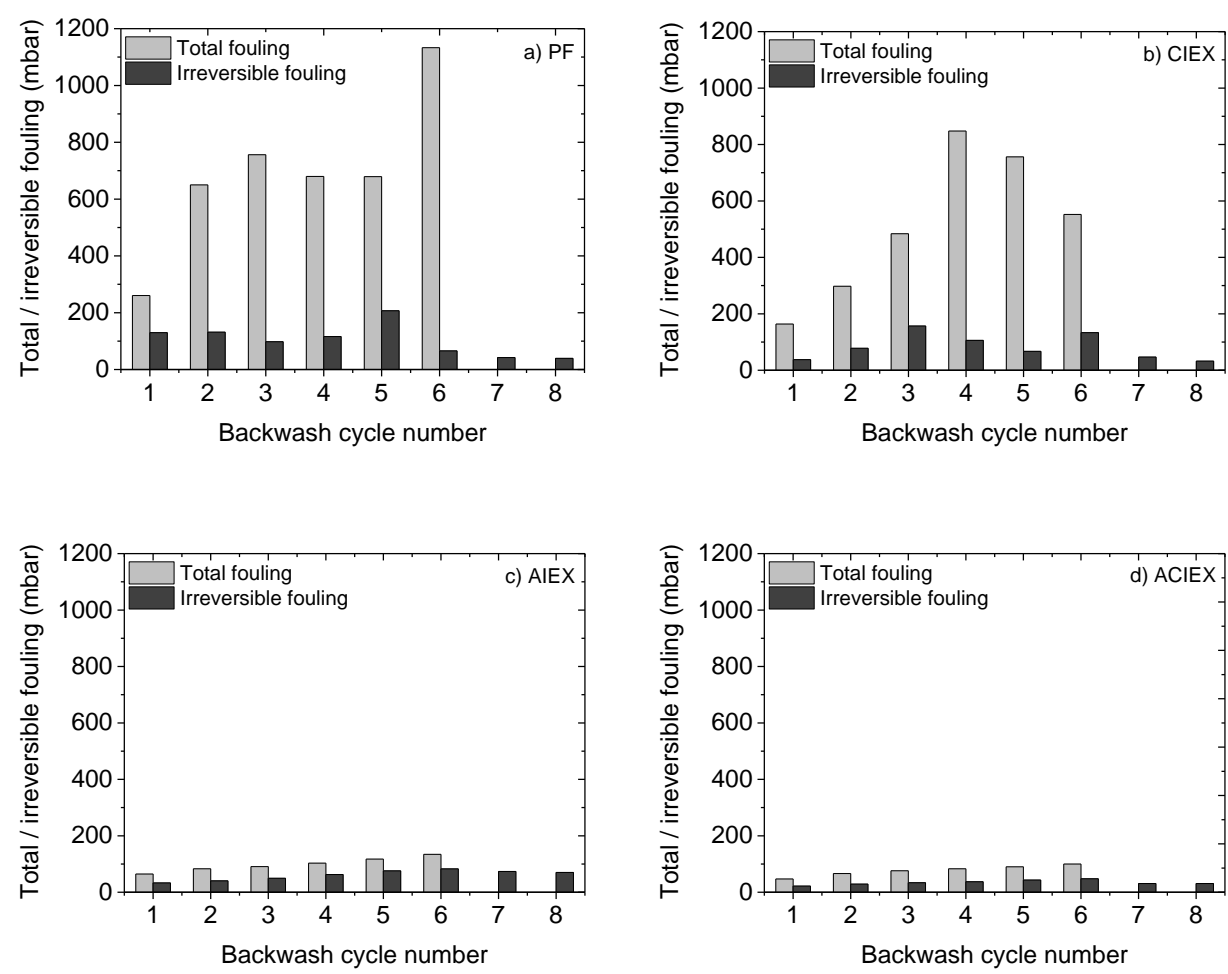

Figure 3-4 Total fouling and irreversible fouling (expressed as pressure increase) versus the backwash cycle number for the various $n C_{60}$ filtration experiments (cycles $\left.1-6\right)$ in the four different water type backgrounds: a) pre-filtered water, b) CIEX treated water, c) AIEX treated water and d) A CIEX treated water. Irreversible fouling after the final flushing procedure is also reported and referred to as cycles 7 and 8 .

The major fraction of the total fouling of waters containing the original NOM composition (PF and CIEX, Fig. 3-4a and b) is mostly reversible, which indicates that the backwashing procedure and the final flushing procedure (referred to as cycles number 7 and 8 in Figure 3- 


\section{Chapter 3}

4) are capable to remove the majority of the foulants accumulated on the membrane. The irreversible fouling is $5.8 \%$ for PF water and $24 \%$ for CIEX water at the end of cycle 6 . The TMP is partially restored to the original value after the backwash cycles. This can be explained considering that a large part of the NOM (2.1 mg/l DOC Table 1) in PF and CIEX water is composed of negatively charged humic acid, which forms a cake-layer on the microfiltration membrane surface (Yuan, Kocic, \& Zydney, 2002) that is apparently easily removed by the backwash procedure using ultrapure water (Fane, Xi, \& Rong, 2006).

Nevertheless, when the cations are removed (CIEX), the remaining irreversible fouling at the end of the filtration experiment (after backwash cycle 6), is higher (24\%) than for PF water. This might be caused by the slightly smaller size of $\mathrm{nC}_{60}$ in CIEX treated water (Figure 3-2 CIEX), resulting in a more compact cake layer that is more difficult to remove. In both cases (PF and CIEX treated water), the fouling that is not removed by backwash cycle 6 is partially removed after the final flushing procedure (cycles number 7 and 8 ) for both PF and CIEX treated water. A possible explanation is that the ultrapure water used in cycles number 7 and 8 removes some of the divalent cations from the cake layer making the following backwash procedure more effective in removing the cake layer (S. Li et al., 2011). This is also visible in the TMP increase (Fig. 3-3a and b) that can then be reduced to its original level.

Removing the negatively charged fraction of NOM (AIEX and ACIEX treated waters, Figure $3-4 c$ and $3-4 d$ ) results in a significant reduction of the total fouling. However, the results in Figure 3-4 show that the total fouling that does occur, is more persistent to the backwash procedure (compared to PF and CIEX treated waters). The irreversible fouling is about $62 \%$ (AIEX) and $48 \%$ (ACIEX) of the total fouling and both the backwashing procedure during filtration and the final flushing procedure at the end of the $\mathrm{nC}_{60}$ filtration experiments are less effective and not sufficient to remove the foulants accumulated on the membrane. Particularly when $\mathrm{Ca}^{2+}$ and $\mathrm{Mg}^{2+}$ are present in the water (AIEX treated water, Figure 3-4c), the irreversible fouling formed in the presence of these ions is more persistent. This can be attributed to enhancement of the irreversible fouling by divalent cation complexation and bridging with NOM (Q. Li \& Elimelech, 2006). Moreover $\mathrm{Ca}^{2+}$ and $\mathrm{Mg}^{2+}$ can assist the formation of complexes between (i) $\mathrm{NOM}$ and $\mathrm{nC}_{60}$ and (ii) $\mathrm{nC}_{60}$ among each other, ultimately resulting in a more resilient cake layer (Kai Loon Chen \& Elimelech, 2007; Grillo 
et al., 2015). This is indicated by a lower TMP decrease after flushing for the AIEX water compared to the ACIEX water (Figure 3-4c and d).

\subsubsection{Removal and fouling mechanism}

In all cases, the observed $\mathrm{nC}_{60}$ removal efficiency was very high $(99.99 \%)$ during all the filtration experiments (see Table S1, Supporting Information). This is in accordance with the removal efficiencies previously obtained for the filtration of $\mathrm{nC}_{60}$ dispersed in ultrapure water (Floris et al., 2016). The removal efficiency was found to be independent of the type of water (Table S1), although the pressure profiles reported in Figure 3-3 suggest different fouling behaviour for the differently treated waters. Although the average $\mathrm{nC}_{60}$ size in surface water is slightly smaller than the size when dispersed in ultrapure water (Floris et al., 2016), the ratio of $\mathrm{nC}_{60}$ size and mean membrane pore size is still comparable. We showed previously (Floris et al., 2016; Trzaskus et al., 2015) that the microfiltration membrane used has a highly non-homogeneous pore size distribution with smaller pores at the inside of the fiber. When dispersed in ultrapure water, this resulted in complete removal of $\mathrm{nC}_{60}$ by a combination of size exclusion and pore blockage. Moreover, if $\mathrm{nC}_{60}$ does not permeate during the first filtration cycle, it is unlikely that permeation will happen in the following cycles as fouling and pore blocking become even more severe during the course of the filtration process. This explains the high removal efficiency during all the cycles of the filtration experiments.

Figure 3-5 reports the development of the slopes (dTMP/dt) of the pressure profiles in time for the 4 different water dispersions and for the first filtration cycle, which is representative for the slopes during all cycles. Slope trends for the remaining cycles 2-6 show similar behaviour as the first one and are reported in the Supporting Information (Figure S2). Analysis of the pressure profile and the change of the slope as function of the time (dTMP/dt, or of the volume filtered dTMP/dV) can give insight in the removal and fouling mechanisms occurring (Chellam \& Cogan, 2011). 

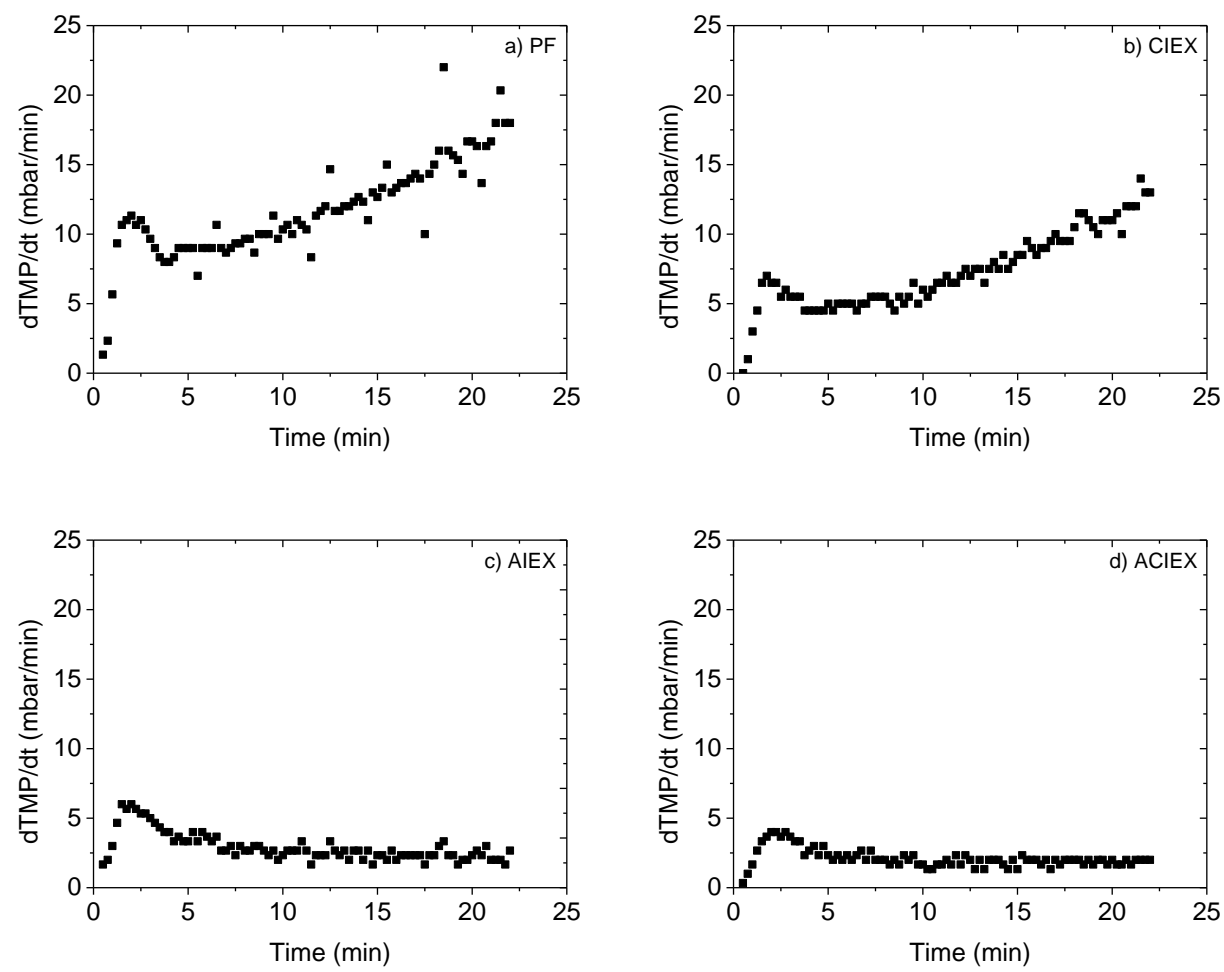

Figure 3-5: Change of dTMP/dt with time for the 4 different water types: a) PF treated water; b) CIEX treated water; c) AIEX treated water; d) ACIEX treated water.

In constant flux filtration, when the cake layer is incompressible, the TMP increases linearly (with a constant dTMP/dt) with time (Chellam \& Xu, 2006). In contrast, when the deposited cake layer is compressible, the pressure profile is convex, so dTMP/dt is not constant but increases in time (Chellam \& Cogan, 2011).

For all investigated waters, as presented in Figure 3-5, a first transition zone (from 0 to $\sim 4$ min) can be identified. In this transition zone, the slope, dTMP/dt, first increases and afterwards decreases again. In this transition zone, most likely pore blocking occurs, as was observed in other studies (Seifollahy Astaraee et al., 2015; Trzaskus et al., 2015). After this transition zone, different behaviour is visible for the different water types. For AIEX and ACIEX treated waters, the slope dTMP/dt stabilizes to a constant value ( $2 \mathrm{mbar} / \mathrm{min})$, which indicates that the TMP increase is linearly related to the filtration time, and thus an 
incompressible cake layer is formed on the membrane surface (Chellam \& Cogan, 2011). In contrast, for water containing all NOM fractions (CIEX and PF waters), after the first initial 4 minutes, the slope, dTMP/dt, linearly increases in time, which means that the cake layer formed on the membrane surface is compressible. During fouling, a compressible cake-layer is formed, ultimately increasing the hydraulic resistance, and thus the TMP increase, during constant flux filtration (Chellam \& Xu, 2006).

It can be hypothesized that the occurrence of a compressible or incompressible cake layer depends on the presence and amount of organic foulants present in the 4 water types: literature shows that during dead-end filtration, the TMP can decrease the thickness and structure of the cake layer (Mendret, Guigui, Schmitz, \& Cabassud, 2009). However, this is only possible when a certain critical amount of foulants is deposited on the membrane. Below this critical value, the structure of the cake layer remains the same, independent of the TMP. Above this limit, the cake layer becomes compressible and its thickness and porosity decrease with increasing TMP. This scenario seems also applicable to our work for the 4 different water type backgrounds without eNPs (Supporting Information). For ACIEX and AIEX treated waters, the slope $\mathrm{dTMP} / \mathrm{dt}$ is constant over all cycles. In contrast, the behaviour of the slope in time for waters containing NOM (PF and CIEX treated waters) indicates the occurrence of two different stages during the formation of the cake layer and its growth: first, the formation of an incompressible cake layer (until cycle 2), and subsequently this layer turns into a compressible layer (after cycle 3 ). Therefore, it is possible that waters containing both $\mathrm{NOM}$ and $\mathrm{nC}_{60}$ already at the first filtration cycle have a total load of foulants higher than the critical value, which makes the cake layer compressible. Nonetheless, the occurrence of synergistic fouling effects of $\mathrm{nC}_{60}-\mathrm{NOM}$ (fractions) can not be excluded, due to particle stabilization by NOM or sterical interferences between the two foulants (Jermann et al., 2008). Therefore, the high increase in TMP observed in Figure 3-3a and 3-3b (PF and CIEX treated waters) can be attributed to (i) the large amount of organic foulants in the water (compared to AIEX and ACIEX treated waters (Figure 3-3c and 3-3d)) and (ii) to cake layer compressibility.

Assuming that pore blocking occurs only at the initial stage of the filtration cycle, as filtration proceeds, the increase of the filtration resistance in time can be related to the formation of a cake layer deposit (Seifollahy Astaraee, Mohammadi, \& Kasiri, 2015; Trzaskus et al., 2015). 


\section{Chapter 3}

SEM photos of the internal membrane surfaces after the filtration experiments of the membranes used in this work confirm this (Figure 3-6). In all cases, a thick deposition layer (>150 $\mathrm{nm}$ ) on the membrane surface can be observed (at the right side of the images), even after the final flushing procedure.
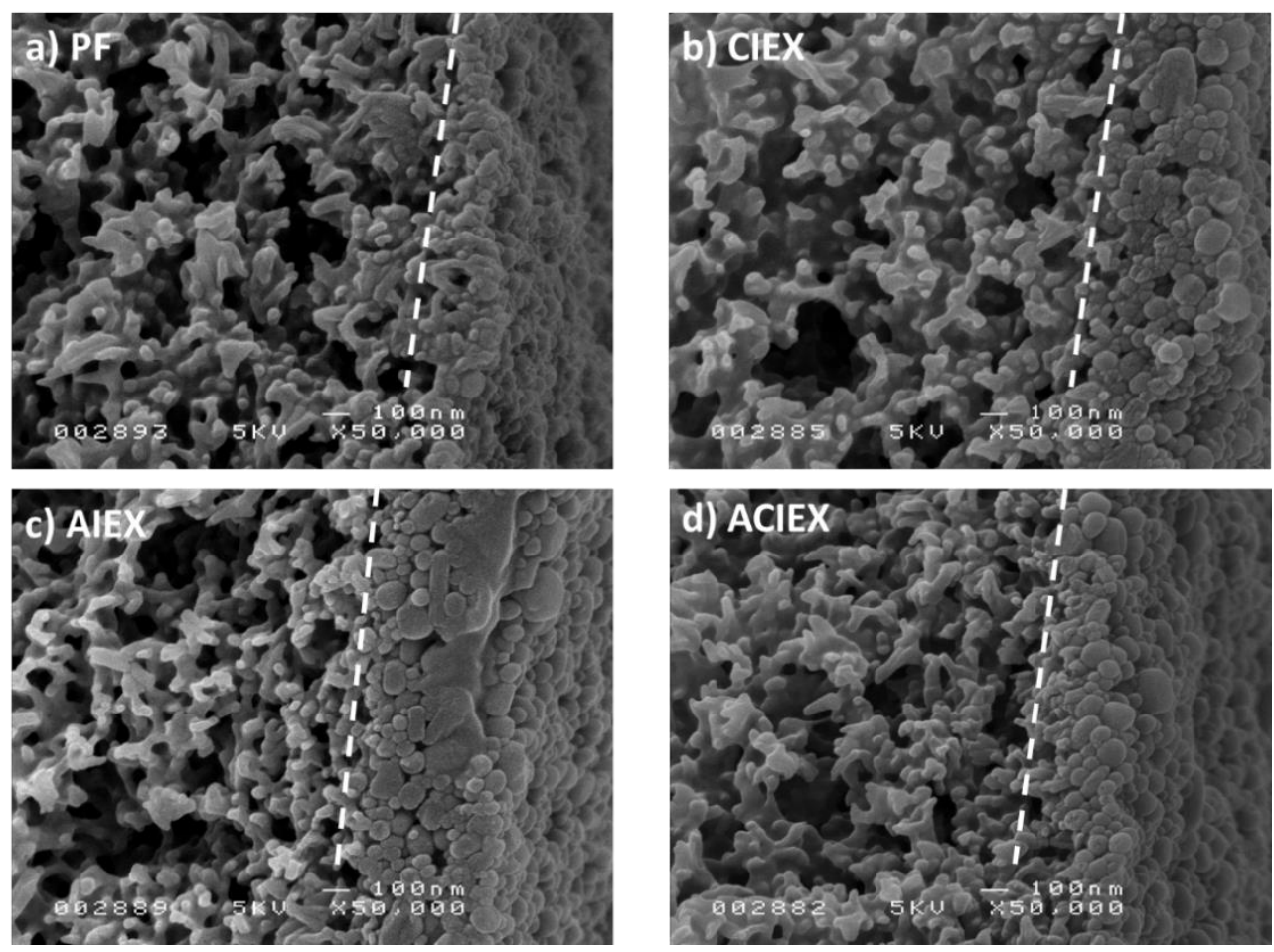

Figure 3-6: SEM images of fouled membranes after 6 filtration and backwash cycles and a final flushing step: a) PF treated water; b) CIEX treated water; c) AIEX treated water; d) ACIEX treated water.

\subsection{Conclusions}

The removal of $\mathrm{nC}_{60}$ using microfiltration was investigated using pre-filtered natural surface water and pre-filtered natural surface water without multivalent cations and/or without the negatively charged part of NOM. Microfiltration membranes are a solid barrier to remove $\mathrm{nC}_{60}$ from surface water during drinking water production and the removal efficiency is found to be $>99.99 \%$ and independent on the surface water composition. However, a synergistic 
effect on membrane fouling between $\mathrm{nC}_{60}$ and surface water constituents such as $\mathrm{NOM}$ and its fractions is observed. Although $\mathrm{Ca}^{2+}$ and $\mathrm{Mg}^{2+}$ are dominant in controlling the stability of $\mathrm{nC}_{60}$ (i.e. particle size and particle zeta potential), the extent of fouling is dominated by the presence of NOM. The negatively charged NOM fractions lead to the formation of a compressible cake layer. Removing this fraction from the feed water results in the formation of an incompressible cake layer and in a reduction of the TMP increase during filtration. Despite the removal of the negatively charged fraction of NOM, the presence of the divalent cations $\mathrm{Ca}^{2+}$ and $\mathrm{Mg}^{2+}$ enhances the formation of irreversible fouling, reducing the efficiency of backwash and final flushing procedures in restoring the initial TMP. These results confirm the resilience of microfiltration in removing $\mathrm{nC}_{60}$ from water under relevant environmental conditions. The results give insight in the effect of the constituents in natural water on the effectiveness of membrane filtration to retain $\mathrm{nC}_{60}$, which is essential to guarantee safe drinking water on the longer run.

\section{Acknowledgement}

This research was sponsored by the Joint Research Programme of KWR Watercycle Research Institute for the Dutch Drinking Water Companies and supported by NanoNextNL, a micro and nanotechnology consortium of the Government of the Netherlands and 130 partners. The authors would also like to acknowledge Herman Teunis (European Membrane Institute Twente) for the SEM analysis, Jens Potreck (Pentair X-Flow) for providing the membranes, Ron Jong (Vitens) for the surface water analysis, Krzysztof Trzaskus (University of Twente) for the help in the $\mathrm{nC}_{60}$ and membrane characterization, Erik Emke and Margo van der Kooi (KWR Watercycle Research Institute) for the $\mathrm{C}_{60}$ concentration analysis. The authors would specially like to thank Harry van Wegen and Sydney Meijering for the assistance with the lab set-up. 


\section{Chapter 3}

\section{References}

Baena, J. R., Gallego, M., Valca, M., \& Division, A. C. (2002). Fullerenes in the analytical sciences. Trends in Analytical Chemistry, 21(3), 187-198.

Bakry, R., Vallant, R. M., Najam-ul-Haq, M., Rainer, M., Szabo, Z., Huck, C. W., \& Bonn, G. K. (2007). Medicinal applications of fullerenes. International Journal of Nanomedicine.

Baun, A., Sørensen, S. N., Rasmussen, R. F., Hartmann, N. B., \& Koch, C. B. (2008). Toxicity and bioaccumulation of xenobiotic organic compounds in the presence of aqueous suspensions of aggregates of nano-C60. Aquatic Toxicology, 86(3), 379-387. doi:10.1016/j.aquatox.2007.11.019

Benn, T. M., Westerhoff, P., \& Herckes, P. (2011). Detection of fullerenes (C60 and C70) in commercial cosmetics. Environmental Pollution (Barking, Essex : 1987), 159(5), 1334-42. doi:10.1016/j.envpol.2011.01.018

Brabec, C. J., Sariciftci, N. S., \& Hummelen, J. C. (2001). Plastic Solar Cells. Advanced Functional Materials, 11(1), 15-26. doi:10.1002/1616-3028(200102)11:1<15::AIDADFM15>3.0.CO;2-A

Brant, J., Lecoanet, H., Hotze, M., \& Wiesner, M. (2005). Comparison of electrokinetic properties of colloidal fullerenes (nC60) formed using two procedures. Environmental Science \& Technology, 39(17), 6343-51.

Carroll, T., King, S., Gray, S. R., Bolto, B. A., \& Booker, N. A. (2000). The fouling of microfiltration membranes by NOM after coagulation treatment. Water Research, 34(11), 2861-2868.

Chae, S., Noeiaghaei, T., Jang, H., Sahebi, S., Jassby, D., Shon, H., ... Park, J. (2015). Effects of natural organic matter on separation of the hydroxylated fullerene nanoparticles by crossflow ultrafiltration membranes from water. SEPARATION AND PURIFICATION TECHNOLOGY, 140, 61-68. doi:10.1016/j.seppur.2014.11.011

Chae, S.-R., Wang, S., Hendren, Z., Wiesner, M., Watanabe, Y., \& Gunsch, C. (2009). Effects of fullerene nanoparticles on Escherichia coli K12 respiratory activity in aqueous suspension and potential use for membrane biofouling control. Journal of Membrane Science, 329(1-2), 68-74. doi:10.1016/j.memsci.2008.12.023

Chellam, S., \& Cogan, N. G. (2011). Colloidal and bacterial fouling during constant flux microfiltration: Comparison of classical blocking laws with a unified model combining pore blocking and EPS secretion. Journal of Membrane Science, 382(1-2), 148-157. doi:10.1016/j.memsci.2011.08.001

Chellam, S., \& Xu, W. (2006). Blocking laws analysis of dead-end constant flux microfiltration of compressible cakes, 301, 248-257. doi:10.1016/j.jcis.2006.04.064

Chen, K. L., \& Elimelech, M. (2007). Influence of humic acid on the aggregation kinetics of fullerene (C60) nanoparticles in monovalent and divalent electrolyte solutions. Journal of Colloid and Interface Science, 309, 126-134. 
Chen, K. L., \& Elimelech, M. (2009). Relating colloidal stability of fullerene (C60) nanoparticles to nanoparticle charge and electrokinetic properties. Environmental Science \& Technology, 43(19), 7270-6.

Chen, K. L., Smith, B. A., Ball, W. P., \& Fairbrother, D. H. (2010). Assessing the colloidal properties of engineered nanoparticles in water: case studies from fullerene C60 nanoparticles and carbon nanotubes. Environmental Chemistry, 7(1), 10-27. doi:10.1071/EN09112

Cho, J., Amy, G., \& Pellegrino, J. (1999). Membrane filtration of natural organic matter: initial comparison of rejection and flux decline characteristics with ultrafiltration and nanofiltration. Water Research, 33(11), 2517-2526. doi:http://dx.doi.org/10.1016/S00431354(98)00498-9

Cornelissen, E. R., Chasseriaud, D., Siegers, W. G., Beerendonk, E. F., \& Kooij, D. Van Der. (2010). Effect of anionic fluidized ion exchange (FIX) pre-treatment on nanofiltration (NF) membrane fouling. Water Research, 44(10), 3283-3293. doi:10.1016/j.watres.2010.03.007

Deguchi, S., Alargova, R. G., \& Tsujii, K. (2001). Stable Dispersions of Fullerenes , C 60 and C 70 , in Water . Preparation and Characterization. Langmuir, 17, 6013-6017.

Duan, J., \& Gregory, J. (2003). Coagulation by hydrolysing metal salts. Advances in Colloid and Interface Science, 102(SUPPL), 475-502.

Fan, L., Harris, J. L., Roddick, F. A., \& Booker, N. A. (2001). Influence of the characteristics of natural organic matter on the fouling of microfiltration membranes. Water Research, 35(18), 4455-4463.

Fane, A. G., Xi, W., \& Rong, W. (2006). Interface Science in Drinking Water Treatment Theory and Application. Interface Science and Technology (Vol. 10). Elsevier. doi:10.1016/S1573-4285(06)80076-1

Farré, M., Pérez, S., Gajda-schrantz, K., Osorio, V., Kantiani, L., Ginebreda, A., \& Barceló, D. (2010). First determination of C60 and C70 fullerenes and N-methylfulleropyrrolidine C60 on the suspended material of wastewater effluents by liquid chromatography hybrid quadrupole linear ion trap tandem mass spectrometry. Journal of Hydrology, 383(1-2), 4451. doi:10.1016/j.jhydrol.2009.08.016

Floris, R., Emke, E., Haftka, J., Hofs, B., Nijmeijer, K., \& Cornelissen, E. R. (2013). Removal efficiency of nC60 nanoparticles by microfiltration membranes. In IWA Symposium on Environmental Nanotechnology (pp. 245-246). Nanjing.

Floris, R., Nijmeijer, K., \& Cornelissen, E. R. (2016). Removal of aqueous nC60 fullerene from water by low pressure membrane filtration. Water Research, 91, 115-125. doi:10.1016/j.watres.2015.10.014

Gottschalk, F., Sun, T., \& Nowack, B. (2013). Environmental concentrations of engineered nanomaterials: review of modeling and analytical studies. Environmental Pollution (Barking, Essex : 1987), 181, 287-300. doi:10.1016/j.envpol.2013.06.003

Grillo, R., Rosa, A. H., \& Fraceto, L. F. (2015). Engineered nanoparticles and organic matter : A review of the state-of-the-art. Chemosphere, 119, 608-619. doi:10.1016/j.chemosphere.2014.07.049 
Guldi, D., \& Prato, M. (2000). Excited-State Properties of C60 Fullerene Derivatives. Accounts of Chemical Research, 33(10), 695-703. doi:10.1021/ar990144m

Henry, C., \& Brant, J. a. (2012). Mechanistic analysis of microfiltration membrane fouling by buckminsterfullerene (C60) nanoparticles. Journal of Membrane Science, 415-416, 546557. doi:10.1016/j.memsci.2012.05.042

Heymann, D. (1996). Solubility of Fullerenes C60 and C70 in Seven Normal Alcohols and Their Deduced Solubility in Water. Fullerene Science and Technology, 4(3), 543-544.

Hofmann, T., \& von der Kammer, F. (2009). Estimating the relevance of engineered carbonaceous nanoparticle facilitated transport of hydrophobic organic contaminants in porous media. Environmental Pollution (Barking, Essex: 1987), 157(4), 1117-26. doi:10.1016/j.envpol.2008.10.022

Hong, S., \& Elimelech, M. (1997). Chemical and physical aspects of natural organic matter (NOM) fouling of nanofiltration membranes. Journal of Membrane Science, 132, 159-181.

Hotze, E. M., Phenrat, T., \& Lowry, G. V. (2010). Nanoparticle Aggregation: Challenges to Understanding Transport and Reactivity in the Environment. Journal of Environment Quality, 39(6), 1909. doi:10.2134/jeq2009.0462

Huang, H., Lee, N., Young, T., Gary, A., Lozier, J. C., \& Jacangelo, J. G. (2007). Natural organic matter fouling of low-pressure, hollow-fiber membranes: Effects of NOM source and hydrodynamic conditions. Water Research, 41(17), 3823-32. doi:10.1016/j.watres.2007.05.036

Hyung, H., \& Kim, J.-H. (2009). Dispersion of C(60) in natural water and removal by conventional drinking water treatment processes. Water Research, 43(9), 2463-70. doi:10.1016/j.watres.2009.03.011

Jafvert, C. T., \& Kulkarni, P. P. (2008). Buckminsterfullerene's (C60) octanol-water partition coefficient (Kow) and aqueous solubility. Environmental Science and Technology, 42(16), 5945-5950.

Jensen, A. W., Wilson, S. R., \& Schuster, D. I. (1996). Biological Applications of Fullerenes. Bioorganic \& Medicinal Chemistry, 4(6), 767-779.

Jermann, D., Pronk, W., \& Boller, M. (2008). Mutual Influences between Natural Organic Matter and Inorganic Particles and Their Combined Effect on Ultrafiltration Membrane Fouling Mutual Influences between Natural Organic Matter and Inorganic Particles and Their Combined Effect on Ultrafiltration Me. Environmental Science \& Technology, 9129-9136.

Jung, Y. K., Kim, M. J., Kim, Y.-J., \& Kim, J. Y. (2013). Limitation of UV-Vis absorption analysis for determination of aqueous colloidal fullerene (nC60) at high ionic strength. KSCE Journal of Civil Engineering, 17(1), 51-59. doi:10.1007/s12205-013-1738-2

Kimura, K., Tanaka, K., \& Watanabe, Y. (2014). Microfiltration of different surface waters with/without coagulation: Clear correlations between membrane fouling and hydrophilic biopolymers. Water Research, 49, 434-443. doi:10.1016/j.watres.2013.10.030

Kolkman, A., Emke, E., Bäuerlein, P. S., Carboni, A., Tran, D. T., ter Laak, T. L., ... de Voogt, P. (2013). Analysis of (functionalized) fullerenes in water samples by liquid 
chromatography coupled to high-resolution mass spectrometry. Analytical Chemistry, 85(12), 5867-74. doi:10.1021/ac400619g

Kroto, H. W., Heath, J. R., O’Brien, S. C., Curl, R. F., \& Smalley, R. E. (1985). C60: Buckminsterfullerene. Nature, 318, 162.

Lee, N., Amy, G., Croué, J.-P., \& Buisson, H. (2004). Identification and understanding of fouling in low-pressure membrane (MF/UF) filtration by natural organic matter (NOM). Water Research, 38(20), 4511-23. doi:10.1016/j.watres.2004.08.013

Li, Q., \& Elimelech, M. (2006). Synergistic effects in combined fouling of a loose nanofiltration membrane by colloidal materials and natural organic matter. Journal of Membrane Science, 278, 72-82. doi:10.1016/j.memsci.2005.10.045

Li, S., Heijman, S. G. J., Verberk, J. Q. J. C., Le, P., Lu, J., Kemperman, A. J. B., ... Dijk, J. C. Van. (2011). Fouling control mechanisms of demineralized water backwash : Reduction of charge screening and calcium bridging effects. Water Research, 5(0), 0-11. doi:10.1016/j.watres.2011.08.004

Lin, D., Liu, N., Yang, K., Xing, B., \& Wu, F. (2010). Different stabilities of multiwalled carbon nanotubes in fresh surface water samples. Environmental Pollution, 158(5), 1270-4. doi:10.1016/j.envpol.2010.01.020

Lyon, D. Y., Adams, L. K., Falkner, J. C., \& Alvarezt, P. J. J. (2006). Antibacterial activity of fullerene water suspensions: effects of preparation method and particle size. Environmental Science \& Technology, 40(14), 4360-6.

Mashayekhi, H., Ghosh, S., Du, P., \& Xing, B. (2012). Effect of natural organic matter on aggregation behavior of C60 fullerene in water. Journal of Colloid and Interface Science, 374(1), 111-7. doi:10.1016/j.jcis.2012.01.061

Mendret, J., Guigui, C., Schmitz, P., \& Cabassud, C. (2009). In situ dynamic characterisation of fouling under different pressure conditions during dead-end filtration: Compressibility properties of particle cakes. Journal of Membrane Science, 333, 20-29. doi:10.1016/j.memsci.2009.01.035

Murayama, H., Tomonoh, S., Alford, J. ., \& Karpuk, M. E. (2004). Fullerene production in tons and more: From science to industry. Fullerenes Nanotubes and Carbon Nanostructures, 12(1-2), 1-9.

Musee, N. (2011). Nanowastes and the environment: Potential new waste management paradigm. Environment International, 37(1), 112-28. doi:10.1016/j.envint.2010.08.005

Navarro, E., Baun, A., Behra, R., Hartmann, N. B., Filser, J., Miao, A.-J., ... Sigg, L. (2008). Environmental behavior and ecotoxicity of engineered nanoparticles to algae, plants, and fungi. Ecotoxicology, 17(5), 372-86. doi:10.1007/s10646-008-0214-0

Nguyen, P., \& Asmatulu, E. (2013). Nanotechnology Safety. Nanotechnology Safety. Elsevier. doi:10.1016/B978-0-444-59438-9.00005-9

Osawa, E. (2002). Perspective of Fullerene Nanotechnology. (Springer, Ed.). Berlin, Germany. 


\section{Chapter 3}

Philippe, A., \& Schaumann, G. E. (2014). Interactions of Dissolved Organic Matter with Natural and Engineered Inorganic Colloids: A Review. Environmental Science and Technology, 48, 8946-8962.

Reisch, M. S. (2009). Innovation: Novel ingredients spread across incosmetics. Chemical and Engineering News.

Sayes, C. M., Gobin, A. M., Ausman, K. D., Mendez, J., West, J. L., \& Colvin, V. L. (2005). Nano-C60 cytotoxicity is due to lipid peroxidation. Biomaterials, 26(36), 7587-95. doi:10.1016/j.biomaterials.2005.05.027

Schafer, A. I. (2000). Microfiltration of colloids and natural organic matter. Journal of Membrane Science, 171, 151-172.

Seifollahy Astaraee, R., Mohammadi, T., \& Kasiri, N. (2015). Analysis of BSA, dextran and humic acid fouling during microfiltration, experimental and modeling. Food and Bioproducts Processing, 94(April), 331-341. doi:10.1016/j.fbp.2014.04.003

Shang, R., Vuong, F., Hu, J., Li, S., Kemperman, A. J. B., Nijmeijer, K., ... Rietveld, L. C. (2015). Hydraulically irreversible fouling on ceramic MF/UF membranes: Comparison of fouling indices, foulant composition and irreversible pore narrowing. Separation and Purification Technology, 147, 303-310. doi:10.1016/j.seppur.2015.04.039

Shen, M., Yin, Y., Booth, A., \& Liu, J. (2014). Effects of molecular weight-dependent physicochemical heterogeneity of natural organic matter on the aggregation of fullerene nanoparticles in mono- and di-valent electrolyte solutions. Water Research, 71, 11-20. doi:10.1016/j.watres.2014.12.025

Shi, X., Tal, G., Hankins, N. P., \& Gitis, V. (2014). Fouling and cleaning of ultrafiltration membranes: A review. Journal of Water Process Engineering, 1, 121-138. doi:10.1016/j.jwpe.2014.04.003

Sillanpää, M. (2015). Natural Organic Matter in Water. Natural Organic Matter in Water. Elsevier. doi:10.1016/B978-0-12-801503-2.00001-X

Song, M., Yuan, S., Yin, J., Wang, X., Meng, Z., Wang, H., \& Jiang, G. (2012). Sizedependent toxicity of nano-C60 aggregates: more sensitive indication by apoptosis-related Bax translocation in cultured human cells. Environmental Science \& Technology, 46(6), 3457-64. doi:10.1021/es2039008

Stone, V., Nowack, B., Baun, A., van den Brink, N., Kammer, F. Von Der, Dusinska, M., ... Fernandes, T. F. (2010). Nanomaterials for environmental studies: classification, reference material issues, and strategies for physico-chemical characterisation. Science of the Total Environment, 408(7), 1745-54. doi:10.1016/j.scitotenv.2009.10.035

Trzaskus, K. W., de Vos, W. M., Kemperman, A., \& Nijmeijer, K. (2015). Towards controlled fouling and rejection in dead-end microfiltration of nanoparticles - Role of electrostatic interactions. Journal of Membrane Science, 496, 174-184. doi:10.1016/j.memsci.2015.06.047

Xie, B., Xu, Z., Guo, W., \& Li, Q. (2008). Impact of natural organic matter on the physicochemical properties of aqueous C60 nanoparticles. Environmental Science \& Technology, 42(8), 2853-9. Retrieved from http://www.ncbi.nlm.nih.gov/pubmed/18497134 
Yamamura, H., Kimura, K., \& Watanabe, Y. (2007). Mechanism Involved in the Evolution of Physically Irreversible Fouling in Microfiltration and Ultrafiltration Membranes Used for Drinking Water Treatment. Environmental Science and Technology, 41(19), 6789-6794.

Yang, K., Zhu, L., \& Xing, B. (2006). Adsorption of Polycyclic Aromatic Hydrocarbons by Carbon Nanomaterials. Environmental Science and Technology, 40(6), 1855-1861.

Yuan, W., Kocic, A., \& Zydney, A. L. (2002). Analysis of humic acid fouling during microfiltration using a pore blockage-cake filtration model. Journal of Membrane Science, 198(1), 51-62. doi:10.1016/S0376-7388(01)00622-6

Zhang, L., Zhang, Y., Lin, X., Yang, K., \& Lin, D. (2014). The role of humic acid in stabilizing fullerene C60 suspensions. Journal of Zhejiang University, 15(8), 634-642. doi:10.1631/jzus.A1400115

Zhang, L., Zhao, Q., Wang, S., Mashayekhi, H., Li, X., \& Xing, B. (2014). Influence of ions on the coagulation and removal of fullerene in aqueous phase. Science of the Total Environment, 466-467, 604-8. doi:10.1016/j.scitotenv.2013.07.077

Zhang, W., Rattanaudompol, U.-S., Li, H., \& Bouchard, D. (2013). Effects of humic and fulvic acids on aggregation of aqu/nC60 nanoparticles. Water Research, 47(5), 1793-802. doi:10.1016/j.watres.2012.12.037 


\subsection{Supporting information}

\subsubsection{Filtration and fouling of surface water without $\mathrm{nC}_{60}$}

Figure 1 shows the total and irreversible fouling (both expressed as TMP increase) over the 6 filtration cycles of the 4 waters investigated without the addition of $\mathrm{nC}_{60}$.
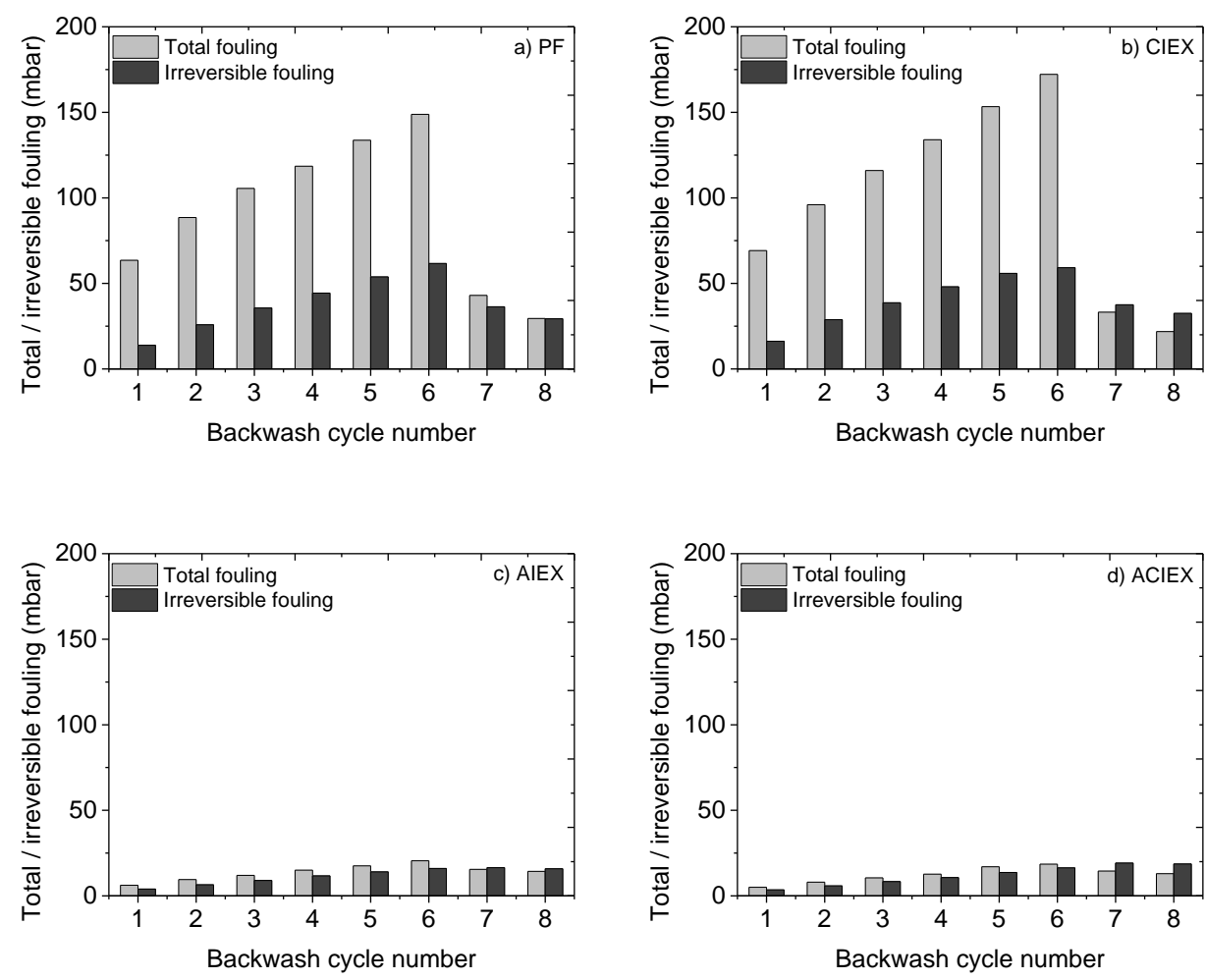

Figure S1: Total fouling and irreversible fouling (expressed as pressure increase) versus the backwash cycle number for the various surface water types without $n C_{60}($ cycles $1-6)$ : a) pre-filtered water, b) CIEX treated water, c) AIEX treated water and d) A CIEX treated water. Irreversible fouling after the final flushing procedure is also reported and referred to as cycles 7 and 8 .

The presence of NOM (PF and CIEX treated water, Fig. S1 a and b) results in high values of total fouling, which can be partially removed again by the backwash procedure (cycles 7 and 
8). Total fouling is significantly reduced when the negatively charged NOM fractions are removed (AIEX and ACIEX treated waters, Fig. S1c and d). However, in these cases, the total fouling formed on the membrane is mostly irreversible, as indicated by the cycles 7 and 8. This can be a consequence of electrostatic charge interactions between the NOM fractions and the membrane. Removal of the negatively charged NOM diminishes the electrostatic repulsion between the foulants and the membrane. Moreover it was found that NOM with neutral constituents, such as polysaccharides, can cause adsorption on polymeric membranes (Cho, Amy, \& Pellegrino, 1999). This therefore results in fouling more persistent to the backwash procedure. 


\section{Chapter 3}

\subsubsection{Membrane rejection}

Table $\mathrm{S} 1$ reports the $\mathrm{nC}_{60}$ rejection for the 4 different water backgrounds and for the 6 filtration cycles.

Table S1: Membrane rejection of $n_{60}$ for the four different waters.

\begin{tabular}{lllll}
\hline \multicolumn{5}{c}{ Water type } \\
\hline & PF & CIEX & AIEX & ACIEX \\
Cycle 1 & 99.99 & 99.99 & 99.99 & 99.99 \\
Cycle 2 & 99.99 & 99.99 & 99.99 & 99.99 \\
Cycle 4 & 99.99 & 99.99 & 99.99 & 99.99 \\
Cycle 6 & 99.99 & 99.99 & 99.99 & 99.99 \\
\hline
\end{tabular}

In all cases, the observed $\mathrm{nC}_{60}$ removal efficiency is very high (99.99\%) during all filtration cycles. This is in accordance with the removal efficiencies previously obtained for the filtration of $\mathrm{nC}_{60}$ in ultrapure water (Floris et al., 2016). The removal efficiency is also found to be independent of the type of water. 


\subsubsection{Fouling development (pressure profiles) in the presence of $\mathrm{nC}_{60}$}

Figure S2 reports the development of the slopes (dTMP/dt) of the pressure profiles in time for the 4 different water dispersions and for the 6 filtration cycles. Slope trends for all the cycles show similar behaviour. 


\section{Chapter 3}
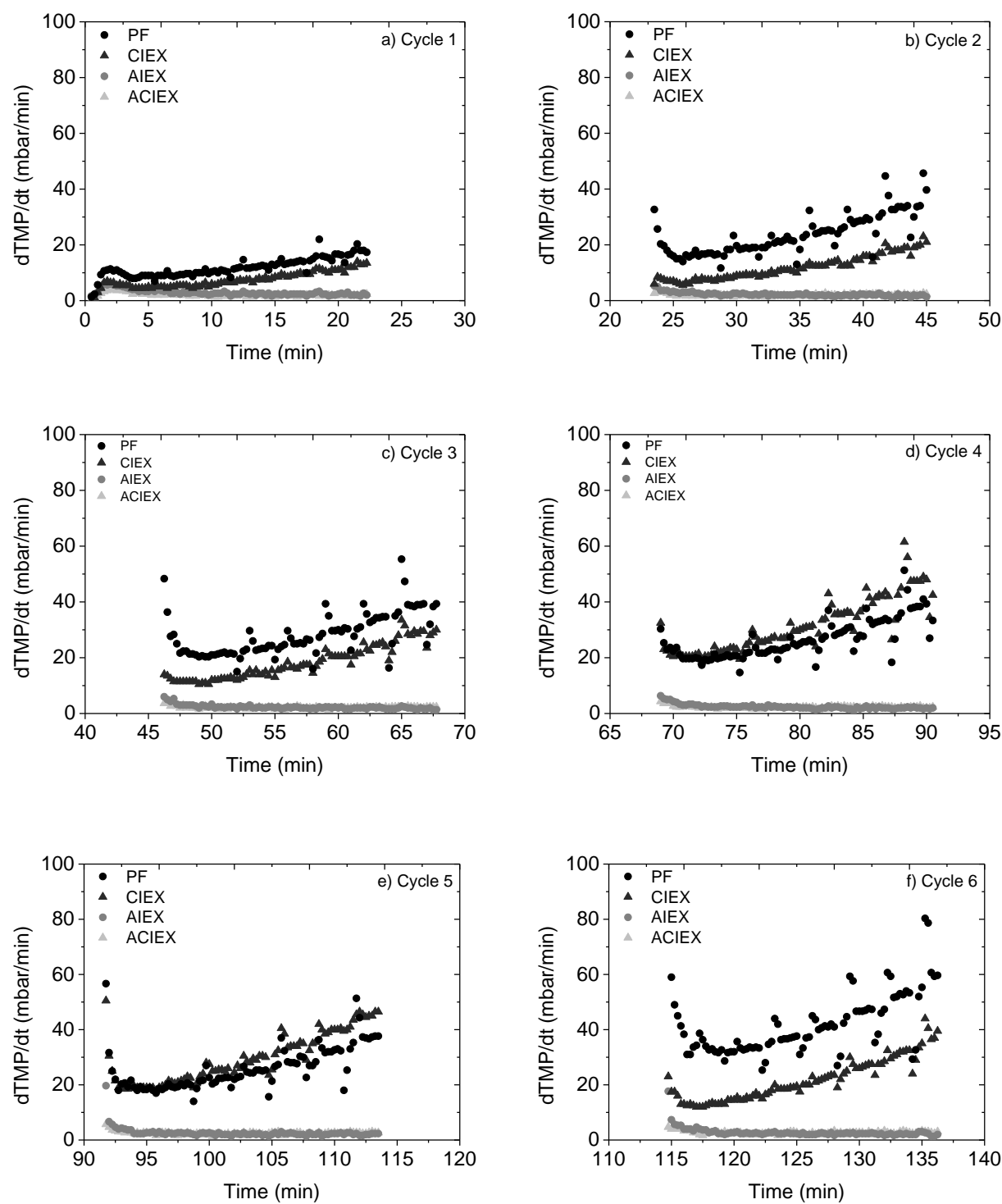

Figure S2: Change of the slope dTMP/dt of the pressure profiles with time for the 4 different water types in the presence of $n_{60}$ and different filtration cycles: a) Cycle 1; b) Cycle 2; c) Cycle 3; d) Cycle 4; e) Cycle 5 and f) Cycle 6. The data of both anion exchange resin treated waters (AIEX and ACIEX) overlap.

When all NOM is present in the water (PF and CIEX waters), the slope dTMP/dt of the pressure profiles increases in time, indicating the formation of a compressible fouling cake 
layer. Removing the negatively charged fraction of NOM from the feed water (AIEX and ACIEX waters) results in a flat dTMP/dt profile, which indicates the formation of an incompressible cake layer.

\subsubsection{Fouling development (pressure profiles) in the absence of $\mathrm{nC}_{60}$}

Figure S3 shows the development of the slopes (dTMP/dt) of the pressure profiles in time for the 4 different waters without $\mathrm{nC}_{60}$. 


\section{Chapter 3}
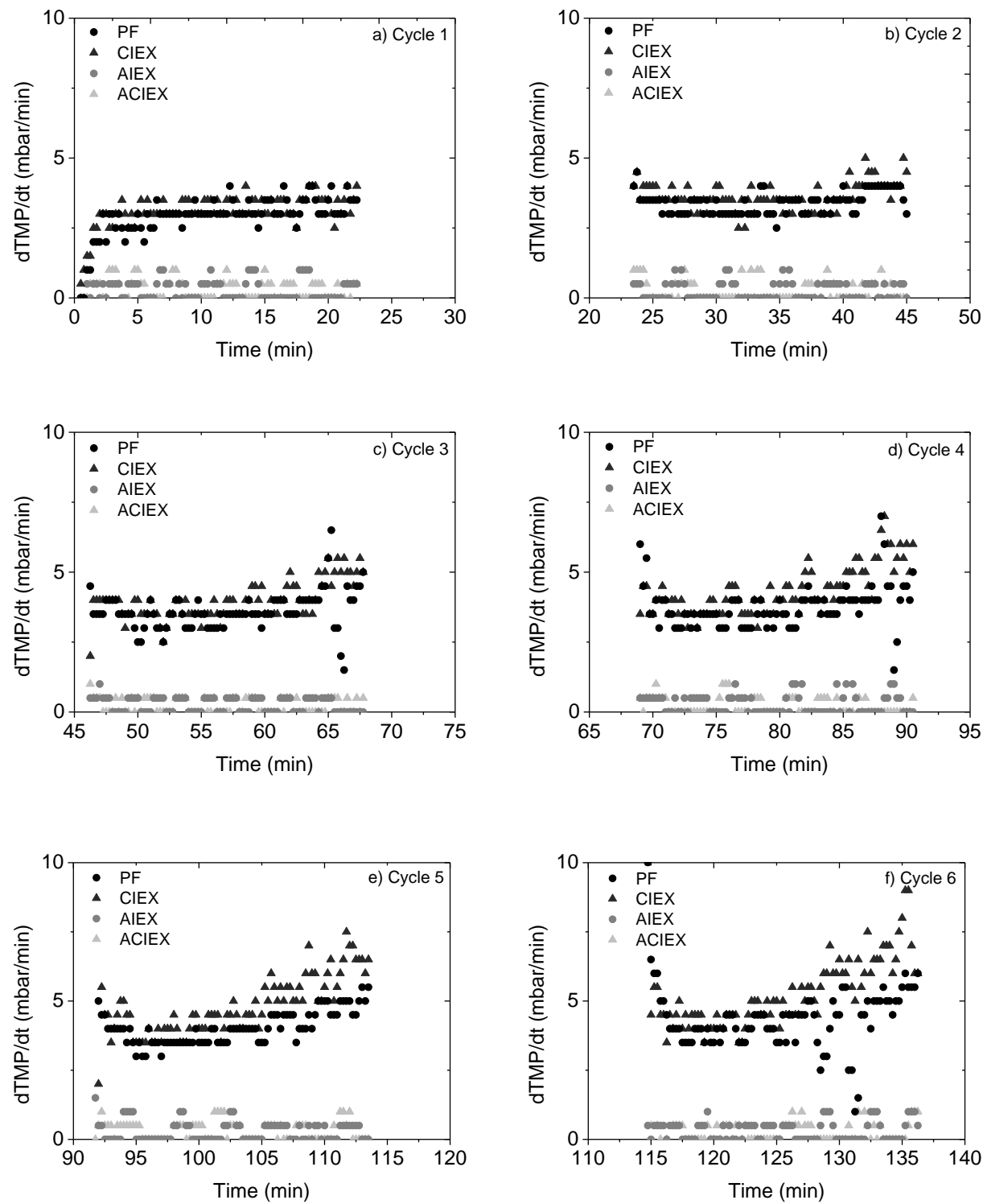

Figure S3: Change of the slope dTMP/dt of the pressure profiles with time for the 4 different water types and different filtration cycles: a) Cycle 1; b) Cycle 2; c) Cycle 3; d) Cycle 4; e) Cycle 5 and f) Cycle 6. The data of PF and CIEX treated water and those of anion exchange resin treated waters (AIEX and ACIEX) overlap. 
In the case of water without any $\mathrm{C}_{60}$, when the negatively charged fraction of NOM is removed from the water (AIEX and ACIEX treated waters), the slope dTMP/dt of the pressure profiles is substantially constant and remains constant during the full filtration. When all NOM is present in the water (PF and CIEX treated waters), the slope dTMP/dt of the pressure profiles keeps substantially constant in time for the first two filtration cycles. At cycles 3 and 4 the slope starts to increase in time. In cycles 5 and 6 the increase becomes more evident.

This behaviour of the slope in time indicates the occurrence of 2 different stages during the formation of the cake layer and its growth: first, the formation of an incompressible cake layer (until cycle 2), and subsequently this layer becomes compressible (after cycle 3 ). This is in agreement with previous studies (Mendret et al., 2009), which demonstrated the link between the characteristics of the cake layer deposit and the amount of foulants deposited on the membrane an consequently the TMP increase. 
4 REMOVAL OF ENGINEERED

NANOPARTICLES FROM WATER

BY LOW-PRESSURE MEMBRANE

FILTRATION - PILOT SCALE

VALIDATION 


\begin{abstract}
Pilot-scale experiments were conducted to evaluate the performance of an industrial membrane-based water treatment process (microfiltration) and to determine its feasibility in removing engineered nanoparticles (eNPs). Filtration experiments with commercially available eNPs were performed on pilot-scale under constant flux operation in dead-end membrane mode, including a backwash cleaning procedure with multiple cycles. The investigation also aimed to validate eNP removal efficiencies previously obtained on labscale (Chapter 2 and 3 of this thesis). The experimental scale-up was accomplished by using industrial microfiltration modules instead of custom lab-scale modules and extending the duration of the filtration time towards industrial practice. It was found that commercial microfiltration membranes with an average pore size larger than the eNP size distribution efficiently removed commercially available eNPs, i.e. silver and gold eNPs, with a removal of $>95.7 \%$ for the silver and of $>99.3 \%$ for the gold eNPs. The removal efficiency was in line with values previously obtained at lab-scale. However, differently from lab-scale experiments, the transmembrane pressure did not increase during filtration, which also precluded the application of blocking law models to determine the eNP removal mechanism. Nonetheless, although a complete analysis of the fouled membranes with microscopy techniques was not performed, visual observations during membrane autopsy suggested that eNPs might be rejected by a possible combination of size exclusion and pore blockage.
\end{abstract}




\section{Chapter 4}

\subsection{Introduction}

The ubiquitous use of commercial products containing engineered nanomaterials (Vance et al., 2015) can result in their release to the environment. Consequently the concentration of eNPs in water bodies is expected to increase in time (Gottschalk et al., 2013). The potential environmental and health risks of such eNPs (Sharifi et al., 2012) in water sources, force the drinking water companies to remove them during water treatment processes to guarantee the production of safe drinking water.

The effectiveness of conventional treatments such as coagulation and flocculation (Hyung and Kim, 2009; Sun et al., 2013; Wang et al., 2013a, 2013b, 2012; Zhang et al., 2014) and advanced treatment such as membrane filtration (Agasanapura et al., 2015; Henry and Brant, 2012; Ladner et al., 2012) in removing eNPs from water has recently been investigated in laboratory studies. In conventional drinking water treatment processes, eNPs are removed by the addition of chemical coagulants to the water, such as alum or iron salts and/or organic polymers (Liu et al., 2012; Zhang et al., 2014). These coagulants remove dispersed colloids, such as eNPs, by two different mechanisms: charge neutralization and sweep flocculation (Duan and Gregory, 2003). Charge neutralization occurs by destabilization of negatively charged eNPs as a result of the cationic products originating from the hydrolysis of the salt coagulants, while flocculation occurs by incorporation of eNPs in the amorphous hydroxide precipitate of the coagulants used in the treatment process (Duan and Gregory, 2003; Liu et al., 2012; Zhang et al., 2014).

The efficiency of conventional water treatment processes to remove eNPs via coagulation, flocculation and sedimentation, depends on parameters such as electrolyte type and concentration and natural organic matter content in the water. Specifically, the presence of electrolytes induces aggregation of eNPs because of electrical double layer compression (Zhang et al., 2008), thus enhancing destabilization, aggregation and thus removal of the eNPs. On the other hand the presence of certain fractions of natural organic matter, like humic acids, greatly decreases the removal rate of eNPs (Hyung and Kim, 2009; Wang et al., 2014) because of steric hindrance effects of humic acids. Also, the additional negative charge of the humic acids imparted to the eNPs enhances their stability, thus decreasing the removal. 
In advanced water treatment using membrane technology, a dependency of the removal efficiency of eNPs to the ratio of the particle size to membrane pore size is observed (Ladner et al., 2012): Particles larger in size than the membrane pore size are retained, while particles smaller than the membrane pore size are not retained (size exclusion). Furthermore, removal mechanisms are influenced by the electrostatic interactions between eNPs and membranes (Agasanapura et al., 2015; Ladner et al., 2012): E.g. negatively charged membranes can retain positively charged eNPs by electrostatic attraction even if the membrane pore diameters are 20 times larger than the eNP diameter (Ladner et al., 2012).

Results obtained by Ladner et al. (2012), although relevant in determining the interactions between the membrane and eNPs, do not consider the membrane fouling that occurs during filtration and its influence on the removal mechanisms of eNPs. As filtration proceeds, the removed eNPs deposit on the membrane surface and/or in the membrane pore structure, which reduces the transport of eNPs through the membrane and increases the eNP removal (Trzaskus et al., 2015). Also the fouling mechanism itself will influence the removal of eNPs. A first study of the fouling of microfiltration membranes by eNPs was conducted by Henry and Brant (2012). Adopting a flat-sheet microfiltration membrane system operated at constant pressure mode, the authors found that filtration of $\mathrm{C}_{60}$ eNPs resulted in severe membrane fouling (rapid flux decline during filtration) explained by particle aggregation, and an increasing cake packing density. The authors concluded that cake formation was the main fouling mechanism of the microfiltration membrane, although also pore blocking occurs, at least during the initial stages of membrane fouling. While Ladner and co-authors found that intercations between eNPs and the membrane surface (i.e.: adsorption by electrostatic attraction) enhances the removal of eNPs during microfiltration, Henry and Brant conversely concluded that the membrane-eNPs interactions only to a limited extent contribute to the removal efficiency. This is because eNP - membrane interactions only play a dominant role at the intial stages of filtration (Trzaskus et al., 2015). In the following stages of fouling development, the forthcoming eNPs will interact with the previously deposited eNPs rather than with the membrane surface itself (Trzaskus et al., 2015).

Although the aforementioned studies provide valuable knowledge on the removal and removal mechanism of eNPs (fullerene, gold, silver and titanium dioxide), especially for low pressure membrane filtration, the results are difficult to translate to real water treatment plants 


\section{Chapter 4}

because the reported studies are performed with a variety of membranes, however of little relevance for the water industry, e.g. polycarbonate track-etched membranes, centrifugal membrane filters and syringe filters (Ladner et al., 2012). Moreover, when relevant membrane configurations were considered such as flat sheet or hollow fiber membrane (Henry and Brant, 2012; Trzaskus et al., 2015), these researches neglected the operational conditions most commonly used in full-scale water treatment applications i.e. operation in constant flux mode including a backwash cleaning procedure. In this thesis (Chapter 2 and 3) we showed on a lab scale that hollow fiber microfiltration membrane systems are effective barriers for the removal of eNPs in drinking water production. Although experiments were performed at lab-scale, they were conducted under constant flux operation in dead-end membrane systems including backwash procedures, as in full-scale water treatment plants (Floris et al., 2016). This work showed that microfiltration membranes can remove fullerene $\mathrm{C}_{60}$ completely (Chapter 2). However, the question remains if these results obtained at labscale conditions are representative for and can be translated to industrial scale installations. Consequently, to evaluate the performance of an industrial membrane-based water treatment process and to determine its feasibility in removing eNPs, in this work we scale up the laboratory experiments to pilot scale. The goal of this investigation is to validate the previously obtained lab-scale results and highlight potential differences in the filtration behavior of eNPs by microfiltration membranes at pilot-scale. The duration of the filtration experiments is extended to align with the industrial application and to evaluate the removal efficiency in time. eNP filtration experiments at pilot-scale were performed under constant flux operation in dead-end membrane mode and including a backwash cleaning procedure with multiple cycles. Filtration was conducted adopting industrial modules of commercially available hollow fiber membranes and eNPs. This study evaluates and discusses the potential and limitations of the use of membrane filtration in water treatment processes for the removal of eNPs from water at pilot scale. It gains insights in the operational practice and reflects on the transferability of the removal of engineered nanomaterials from lab-scale to full-scale systems. 


\subsection{Material and Methods}

\subsubsection{Reagents and Chemicals}

Commercially available eNP silver and gold eNPs dispersions (Mesosilver ${ }^{\mathrm{TM}}$ and Mesogold ${ }^{\mathrm{TM}}$ ) were obtained from Purest Colloids (New Jersey, USA). According to the manufacturer both colloidal dispersions are pure silver and gold dispersed in deionized water produced by electrolysis and added at a concentration of at least $20 \mathrm{ppm}$.

\subsubsection{Preparation of eNPs dispersions for filtration}

Before use, the silver and gold eNP dispersions were mixed together in an equal amount in a mixing vessel. Tap water from a groundwater source at Spannenburg (Vitens) was added to this mixture to reach a concentration of eNPs (total of silver and gold) of $4 \mathrm{mg} / \mathrm{l}$. Prior to feed the membranes with this mixture of silver and gold eNPs in tap water, it was further diluted 10 times to a concentration of $0.4 \mathrm{mg} / \mathrm{l}$ by an in-line dosing system in the pilot setup, as described in section 2.5 .

\subsubsection{Characterization of eNPs size}

Concentrations (measured as number of particles per ml), size distribution of the silver and gold eNPs in the stock dispersions and their diluted mixtures in tap water were determined at the Vitens Laboratory (Leeuwarden, the Netherlands). To determine the number concentration of eNPs and their size distribution, inductively coupled plasma-mass spectroscopy (ICP-MS) measurements were performed in the single particle counting mode (Degueldre and Favarger, 2003; Mitrano et al., 2012). The method itself is based on recording a time-resolved spectrum from a diluted eNPs dispersion. The particles are detected as spikes in the trace as counts per second with ICP-MS analyses. The dwell time and flow rate were set at $10 \mathrm{~ms}$ and $1 \mathrm{ml} / \mathrm{min}$ respectively. The frequency of the peaks is proportional to the number concentration of eNPs in the sample, while the intensity of the peaks is proportional to the mass of the element, allowing the calculation of the eNPs size (assuming solid spheres). 


\section{Chapter 4}

The minimum detectable particle size for silver and gold was estimated by the Vitens Laboratory to be $30 \mathrm{~nm}$, which is slightly higher than the minimum range $(10-20 \mathrm{~nm}$ depending on the species of interest) reported in literature (Lee et al., 2014). A more detailed description of this method can be found in Degueldre and Favarger, (2003) and Mitrano et al. (2012).

The water composition given in Table 4-1 of the tap water used in the filtration experiments was determined as well by the Vitens laboratory (Leeuwarden, the Netherlands) with an inhouse method VL-W-ACO1/02, VL-W-ME04, VL-T-AL35 and VL-W-00O2 according to NEN-EN-ISO/IEC 17025 NEN-EN-ISO 9001:2008, OHSAS 18001:2007 and ISO 14001:2004 standards.

\section{Table 4-1: Water composition used for filtration experiments}

\begin{tabular}{ll}
\hline Turbidity $(\mathrm{NTU})$ & 0.2 \\
Conductivity $(\mu \mathrm{S} / \mathrm{cm})$ & 55.4 \\
$\mathrm{pH}$ & 7.7 \\
$\mathrm{DOC}(\mathrm{mg} / \mathrm{l})$ & 4 \\
$\mathrm{HCO} 3-(\mathrm{mg} / \mathrm{l})$ & 174.5 \\
$\mathrm{Ca} 2+(\mathrm{mg} / \mathrm{l})$ & 62.1 \\
$\mathrm{Mg} 2+(\mathrm{mg} / \mathrm{l})$ & 9.3 \\
$\mathrm{CO} 2(\mathrm{mg} / \mathrm{l})$ & 6.4 \\
$\mathrm{Color}[\mathrm{mg} \mathrm{Pt} / \mathrm{Co} / \mathrm{l}]$ & 8.8 \\
$\mathrm{UV}[1 / \mathrm{m}]$ & 10.2 \\
Temperature $\left[{ }^{\circ} \mathrm{C}\right]$ & 11.0 \\
Total hardness $(\mathrm{mmol} / \mathrm{l})$ & 1.9 \\
\hline
\end{tabular}

The tap water composition reported in Table 1 shows a very low turbidity value and relatively high DOC and $\mathrm{Ca}^{2+}$ and $\mathrm{Mg}^{2+}$ content. Similar values are reported for other tap water qualities in the Netherlands (Hofs et al., 2012). 


\subsubsection{Membrane and membrane characterization}

The membranes used in the experiments were commercially available PES-PVP microfiltration membranes (Pentair X-Flow MF02 M2). The modules supplied by Pentair XFlow BV (the Netherlands) and were $1 \mathrm{~m}$ long with and external diameter of $10 \mathrm{~cm}$. The module contained 180 membrane fibers with $3 \mathrm{~mm}$ internal diameter resulting in a filtration area of $1.5 \mathrm{~m}^{2}$. The membranes were operated in inside-out configuration, dead-end mode and at a constant filtration flux. Prior to the filtration experiments the membranes were flushed with reverse osmosis (RO) permeate for 2 hours at $60 \mathrm{l} / \mathrm{m}^{2} \cdot \mathrm{h}$ to remove any preservation liquids Membranes were fully characterized elsewhere (Floris et al., 2016; Trzaskus et al., 2015) and the main properties are reported in Table 2.

\section{Table 4-2: Membrane and module characteristics}

\begin{tabular}{ll}
\hline Table Commercial name & MF02 M2 \\
Membrane process & Microfiltration \\
Pore size* $[\mathrm{nm}]$ & 200 \\
Average pore size measured $[\mathrm{nm}]$ & 186.6 \\
Smallest pore size measured $[\mathrm{nm}]$ & 180.6 \\
Filtration area $\left[\mathrm{m}^{2}\right]$ & 1.5 \\
Inner fiber diameter $[\mathrm{mm}]$ & 3 \\
Zeta potential** $[\mathrm{mV}]$ & $-19.8 \pm 5.1$ \\
\hline
\end{tabular}

* As provided by the manufacturer; ** Measured at $\mathrm{pH} 6.5$

\subsubsection{Membrane filtration process and filtration procedure}

The pilot tests were executed at the Vitens Innovation Center in Noardburgum (the Netherlands). A fully automatic pilot unit suitable for membrane modules was used and its flow scheme is given in Figure 4-1. 


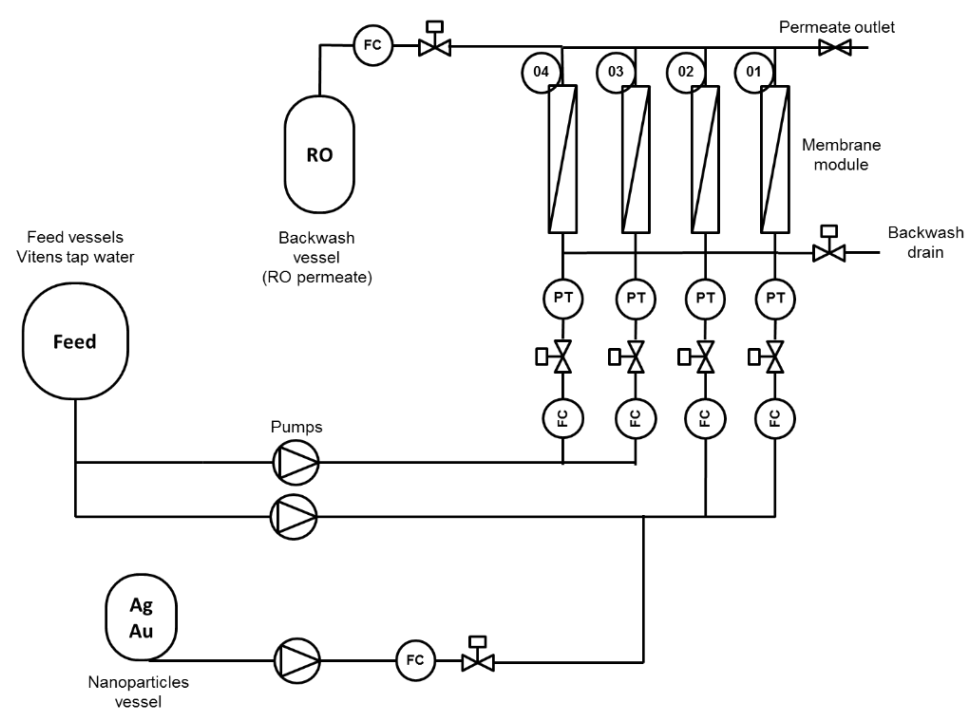

Figure 4-1: Flow scheme of the microfiltration pilot installation.

The pilot unit was equipped with four microfiltration modules. Two modules were used as blank experiments and fed in parallel with tap water only, while the other two modules were used in parallel for the filtration of the eNP feed dispersion mixture. The mixture of silver and gold eNPs was prepared in the dosing vessel with a mixer provided in the system as described in section 2.2. The dosing of eNPs to the feed dispersion was achieved by an inline dosing system prior to the membrane module inlet. The filtration flux was set at $60 \mathrm{l} / \mathrm{m}^{2} \cdot \mathrm{h}$ and the interval period between backwashes was set to $60 \mathrm{~min}$. Membrane modules were backwashed with permeate water of a RO installation available at the Vitens Innovation Center. The backwash flow rate was $240 \mathrm{l} / \mathrm{m}^{2} \cdot \mathrm{h}$ for a duration of 1 minute. The total duration of the filtration experiment was 46 hours continuously. Feed and permeate samples of the 4 modules were collected and analyzed for water quality assessment and eNPs removal efficiency as described in section 2.3. To monitor possible changes in water parameters, water quality analysis was performed for feed and permeate samples at the beginning and at the end of the filtration experiments and at filtration cycle number 17. Analysis of eNPs was performed for 20 samples taken at filtration cycles number 1, 2, 11-24 and 43-46. Only 20 out of 46 cycles were sampled for eNPs analysis due to the lack of an auto sampling system. 
The removal efficiency (R [\%]) of silver and gold eNPs calculated as rejection was obtained from Equation 1:

$$
R=\left(1-\frac{C_{p}}{C_{f}}\right) \times 100
$$

Where $C_{p}$ is the permeate concentration [number of particles/ml] and $C_{f}$ is the feed concentration [number of particles/ml] of silver and gold.

The lab-scale transmembrane pressure (TMP) were determined performing experiments with the lab-scale apparatus described in Chapter 2 and 3 using the same commercial membrane potted in custom made modules of $20 \mathrm{~cm}^{2}$ (Chapter 2 and 3). Silver and gold eNPs were mixed with tap water to reach a total eNPs concentration of $0.4 \mathrm{mg} / 1$. The filtration procedure was identical to the pilot-scale experiments: a filtration flux of $60 \mathrm{l} / \mathrm{m}^{2} \cdot \mathrm{h}$, every 60 minutes a backwash at $240 \mathrm{l} / \mathrm{m}^{2} \cdot \mathrm{h}$ during 1 minute. The experiment lasted 46 cycles.

\subsection{Results and discussion}

\subsubsection{Water composition}

During the pilot testing period of 46 hours, the water composition of the feed and the permeate remained constant. Filtration of the feed water through the microfiltration membranes had no effect on the water composition of the permeate, either with or without eNPs (Table A1 in Appendix). The ions measured in this work $\left(\mathrm{Ca}^{2+}\right.$ and $\left.\mathrm{Mg}^{2+}\right)$ are smaller than the membrane pore size and cannot be retained by the microfiltration membrane. Similarly, the organic matter measured as DOC has a molecular size smaller than the membrane pore size (Nissinen et al., 2001). 


\subsubsection{Characterization of silver and gold eNPs dispersions}

Silver and gold eNP size distributions were determined for the stock dispersions in deionized water (as received from the manufacturer) and for the feed dispersions in tap water just before the filtration experiments.

Figure 4-2 reports the eNP size distributions in deionized and in tap water for a) silver eNPs and b) gold eNPs.
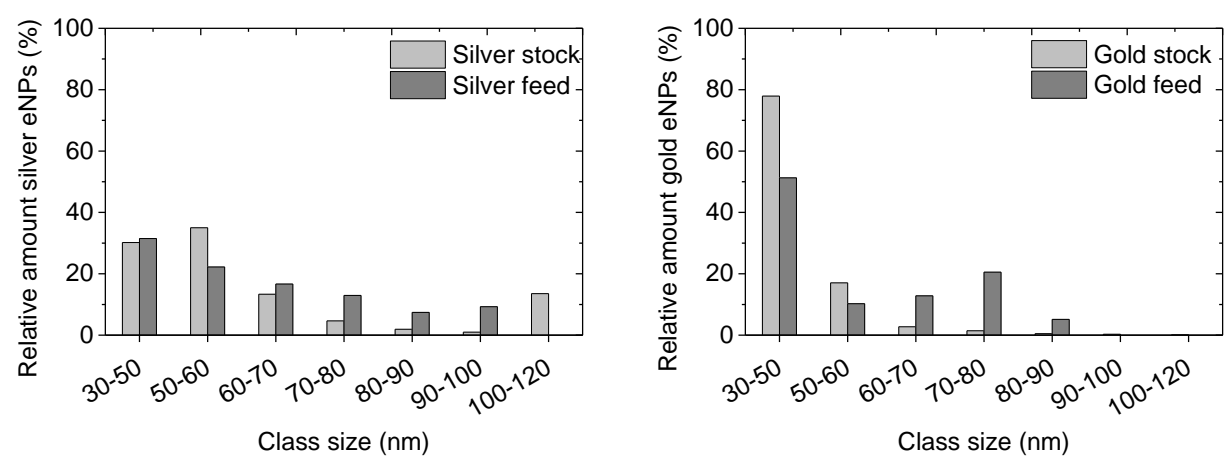

Figure 4-2: Silver and gold eNP size distributions as determined from single particle ICP$M S$ measurements for the stock eNP dispersion in deionized water as received from the manufacturer and for the feed eNP dispersion in tap water sampled at the beginning of the filtration experiment.

Silver and gold eNP size distributions range between 30 to $100 \mathrm{~nm}$ for silver eNPs and range between 30 to $90 \mathrm{~nm}$ for gold eNPs when dispersed in deionized water (light grey bars in Figure 4-2). For both silver and gold a slight shift to larger sized aggregates can be observed when eNPs are dispersed in tap water (dark grey bars in Figure 4-2). This shift indicates that some aggregation of eNPs occurs when mixed with tap water. This aggregation of eNPs is attributed to the presence of divalent cations in the tap water as shown in Table 4-1. The aggregation of eNPs in the presence of divalent cations is in line with previous studies that report silver and gold eNP aggregation in monovalent and divalent electrolyte backgrounds (Huynh and Chen, 2011; Liu et al., 2013). Although eNPs are slightly aggregated when present in the tap water, the size range is still smaller than $200 \mathrm{~nm}$, which is the size of the membrane pores (Table 4-2). 
Previous characterization (Farmen et al., 2012) of the same commercial silver stock dispersion in deionized water by transmission electron microscopy showed that the particle size distribution of commercial silver eNPs ranged from 1 to $40 \mathrm{~nm}$. Differences between our measurements and those of previous work can be explained considering that the size detection limit of single particle ICP-MS was $30 \mathrm{~nm}$. Therefore fractions smaller than this limit cannot be detected. The total silver content (ionic and particulate form) in the stock dispersion as received from the manufacturer was found to be $25.9 \pm 1.1 \mathrm{mg} / \mathrm{l}$ (laboratories of Vitens water company). This is in agreement with previous measurements $(23.4 \pm 1.2 \mathrm{mg} / \mathrm{l}$ (Ellegaard-Jensen et al., 2012)). The zeta-potential of the silver stock dispersion, as obtained from literature, was highly negative $(-61.97 \pm 2.2 \mathrm{mV})$ (Ellegaard-Jensen et al., 2012).

\subsubsection{Removal efficiency}

Figure 4-3 shows the removal efficiency of eNPs calculated as rejection based on number of eNPs per volume. The removal efficiency was always $>95.7 \%$ for the silver and $>99.3 \%$ for the gold eNPs, although all eNP particles/aggregates are considerably smaller than the membrane pore size.

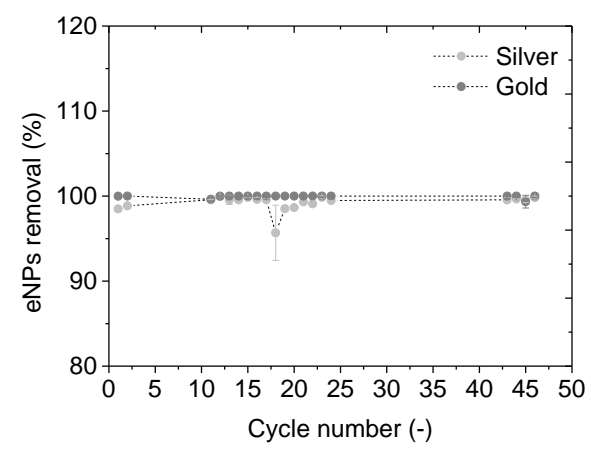

Figure 4-3: Removal efficiency of silver and gold eNPs using microfiltration for 20 out of 46 cycles (cycle 1, 2, 11-24 and 43-46) sampled during the experimental run of 46 hours. 
Size distributions of the eNPs detected in the feed and the permeate samples of the first filtration run are reported in Figure 4-4a and $\mathrm{b}$ for the silver and gold eNPs respectively. Results are representative for all filtration runs.
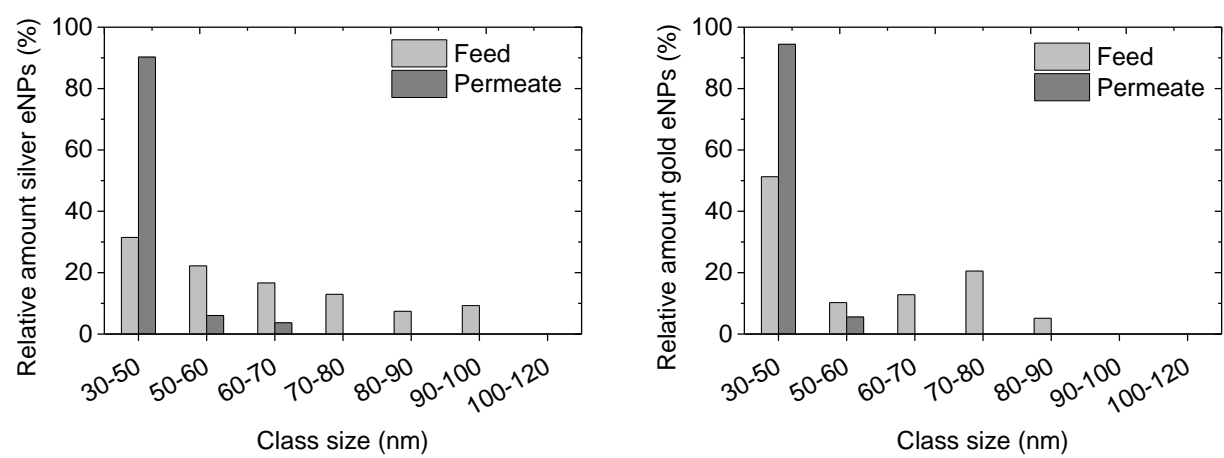

Figure 4-4: Relative eNP size distributions for feed and permeate of the first filtration cycle (representative for the full duration of the experiment) for silver eNPs (left) and gold eNPs (right).

Although all eNP sizes are smaller than the membrane pore size, Figure 4-4 reveals that only the particle fractions with the smaller particles $(<70 \mathrm{~nm}$ for silver and $<60 \mathrm{~nm}$ for gold) can pass through the microfiltration membrane (Figure 4 dark grey bars). Nonetheless, the majority of the eNPs is retained resulting in removal values $>95.7 \%$ for the silver and > 99.3\% for the gold eNPs (Figure 4-3). Similar findings were previously obtained in microfiltration of $\mathrm{C}_{60}$, silver, gold and $\mathrm{TiO}_{2}$ eNPs (Floris et al., 2016; Ladner et al., 2012; Trzaskus et al., 2015). Particles smaller than the pore size of the membrane can also be removed by adsorption or adhesion to the membrane surface, by electrostatic interactions (Ladner et al., 2012) or due to other mechanisms like cake formation and pore blocking (Trzaskus et al., 2015). Silica eNPs smaller in size than membrane pore size were also removed by microfiltration in a dead-end configuration (Trzaskus et al., 2015) by a combination of pore blocking and cake layer filtration. $\mathrm{C}_{60}$ particles, which are not only smaller than the microfiltration membrane pore sizes but also carry a negative charge were effectively removed (Floris et al., 2016) by the same microfiltration membranes. After an extended analysis of operational parameters, scanning electron microscopy analysis and pore blocking models, it was concluded that the removal mechanism of $\mathrm{C}_{60}$ particles by 
microfiltration membranes is a combination of size exclusion, pore blockage and cake layer formation (Floris et al., 2016). As these $\mathrm{C}_{60}$ particles are comparable in size and charge as the silver and gold eNPs used here, it was hypothesized that the same mechanisms apply during the filtration of silver and gold eNPs. Figure 4-5 shows the cross section of the membrane module after 46 filtration and backwash cycles of silver and gold eNPs dispersed in tap water (left) and of the membrane module used in parallel in a blank experiment and fed with tap water without eNPs (right).

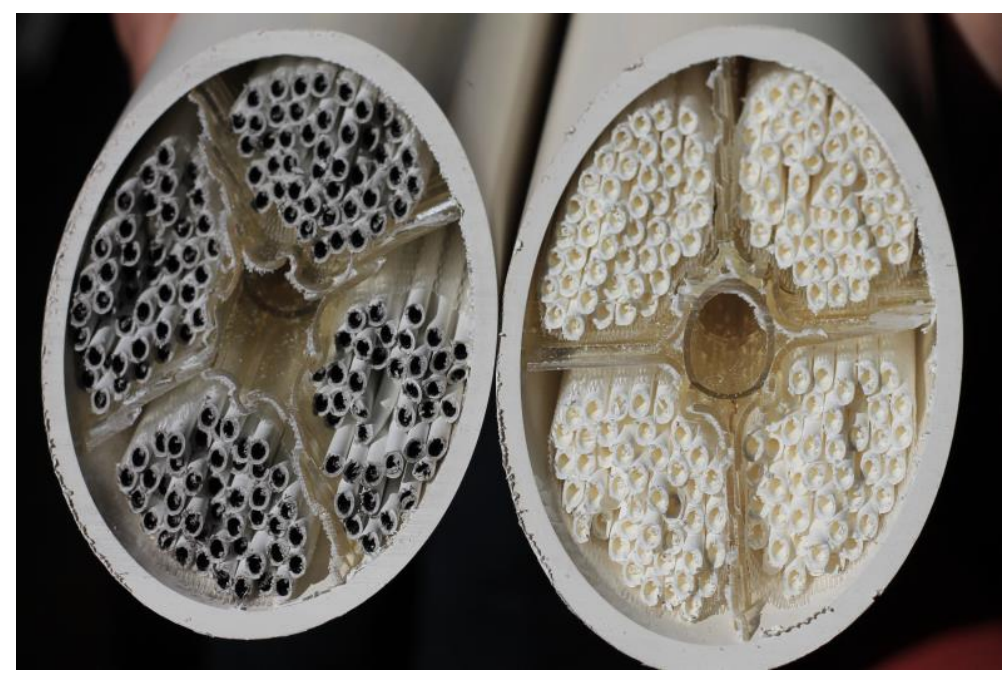

Figure 4-5: Autopsy photo of the cross section of the membrane module after 46 filtration and backwash cycles. Left: Module after filtration of tap water containing eNPs; Right: Similar module after filtration of tap water without eNPs. Modules are cut under an angle of $46^{\circ}$. The image is taken from above to better show the deposition. The small white particles are the result of the cutting of the module.

The inner membrane surface of the microfiltration membranes was covered with a homogeneous dark blackish deposition layer consisting of silver and gold eNPs (Figure 4-5). This deposition layer was not observed in the membranes used in the control experiment without eNPs as shown in the picture at the right side in Figure 4-5. 


\section{Chapter 4}

Figure 4-6 shows the visual effects of the deposition layer on the inner membrane surface along the length of one fiber ( $1 \mathrm{~m}$ length) that, for better representation, was cut in 6 pieces. The inner appearance of all fibers was similar and the result of only one (representative) fiber is reported here.

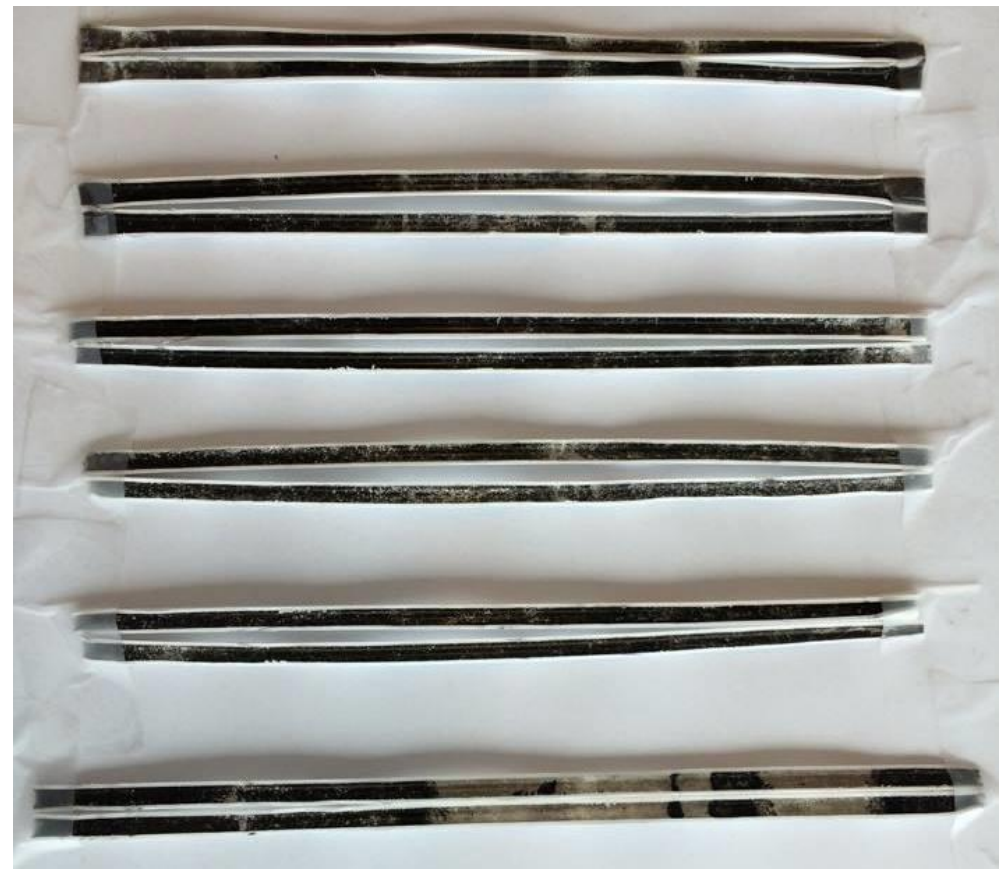

Figure 4-6: Autopsy photo of a representative membrane fiber cut in 6 pieces after 46 filtration and backwash cycles.

The lighter shades in the deposited black layer can be the result of the backwash procedure removing the eNPs accumulated on the membrane. The external surface of the membrane (permeate side) did not show any visible deposition of eNPs as is visible in Figure 5. Although a complete characterization (e.g. comprising scanning electron microscopy) of the fouled membranes is not performed in this study, visual observations (Figure 5 and 6) of the fouled membranes clearly show the deposition of eNPs on the inside of the membranes. 
Figure 4-7 shows the transmembrane pressure (TMP) profile over the membrane during the course of the experiment.

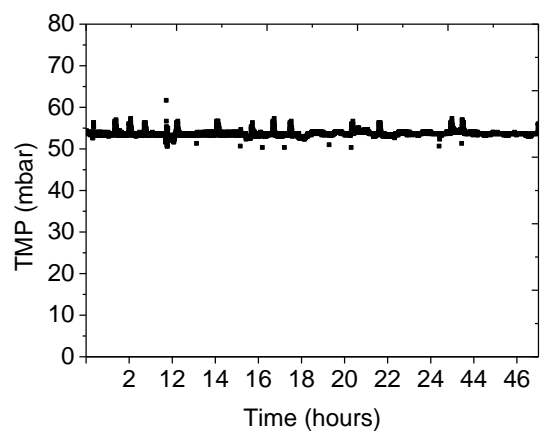

Figure 4-7: Representative transmembrane pressure (TMP) profile versus time for the pilotscale filtration experiments of silver and gold eNPs dispersed in tap water (results obtained in a lab scale set up).

The TMP pressure profile was obtained by replication of the silver and gold pilot scale filtration experiment with the lab-scale installation used for the $\mathrm{C}_{60}$ experiments as described in Chapter 2 and 3. This was done to validate the lab-scale results using silver and gold eNPs and to highlight potential differences in the filtration behavior of these eNPs by microfiltration membranes at pilot-scale (Chew et al., 2015). Although a TMP pressure increase was observed during $\mathrm{C}_{60}$ filtration (Floris et al., 2016), the TMP pressure profile during silver and gold eNP filtration appeared reasonable flat (Figure 7). The absence of a TMP pressure increase makes it impossible to apply the blocking law model to identify the removal mechanism based on operational parameters. Therefore, assuming that eNP surface deposition occurs (as visually observed (Figure 5 and 6)), the flat pressure profile compared to the increasing pressure profile upon $\mathrm{C}_{60}$ eNP filtration can be the result of (i) different filtration resistance of the cake layer formed on the top of the membrane resistance due to the different nature of eNPs or (ii) the formation of a cake layer only without the occurrence of pore blocking on the membrane surface. More research is needed to clarify how separation of silver and gold eNPs from water using microfiltration occurs and to clarify these specific observations. 


\section{Chapter 4}

\subsection{Conclusions}

Silver and gold eNP dispersions in tap water were efficiently removed (>95.7\% for the silver and $>99.3 \%$ for the gold eNPs) by commercial microfiltration membranes with an average pore size significantly larger than the eNP size distribution. These finding are similar to what is previously reported for $\mathrm{C}_{60}$ eNPs (Floris et al., 2016), silver, gold and $\mathrm{TiO}_{2}$ eNPs (Ladner et al., 2012) and silica eNPs (Trzaskus et al., 2015). Therefore, this study suggests that labscale results can be translated to pilot scale performances in terms of removal efficiency. Size distributions of silver and gold eNPs in the permeate samples as determined from single particle ICP-MS measurements, indicate that the complete removal of eNPs was not achieved because. All eNP sizes are significantly smaller than the membrane pore size and the smallest eNPs fractions ( $<70 \mathrm{~nm}$ for silver and $<60 \mathrm{~nm}$ for gold) can pass through the microfiltration membrane. This study also confirms the removal efficiency in a long filtration run of 46 hours, which is longer than previous results obtained at lab-scale. Although a complete analysis of the fouled membranes with microscopy techniques was not performed, visual observation during membrane autopsy seems to suggest that silver and gold eNPs are rejected by a combination of size exclusion and pore blockage (Floris et al., 2016). Nonetheless it was not possible to validate the removal mechanism using a blocking law model, due to the absence of significant variation of the TMP pressure during the filtration time.

\section{Acknowledgement}

This research was sponsored by the Joint Research Programme of KWR Watercycle Research Institute for the Dutch Drinking Water Companies and supported by NanoNextNL, a micro and nanotechnology consortium of the Government of the Netherlands and 130 partners. The authors would like to acknowledge Ron Jong and Janneke Duiven - Wiegersma (Vitens) for the support in providing and measuring the eNPs dispersions and the experimental pilot execution at the Vitens Innovation Center in Noardburgum (the Netherlands). The authors would specially like to thank Jens Potreck (Pentair X-Flow) for kindly providing the commercial membrane modules. 


\section{References}

Agasanapura, B., Baltus, R.E., Tanneru, C.T., Chellam, S., 2015. Effect of electrostatic interactions on rejection of capsular and spherical particles from porous membranes: Theory and experiment. J. Colloid Interface Sci. 448, 492-500. doi:10.1016/j.jcis.2015.02.016

Chew, C.M., Aroua, M.K., Hussain, M.A., 2015. Key issues of ultrafiltration membrane water treatment plant scale-up from laboratory and pilot plant results. Water Sci. Technol. Water Supply in press. doi:10.2166/ws.2015.154

Degueldre, C., Favarger, P.-Y., 2003. Colloid analysis by single particle inductively coupled plasma-mass spectroscopy: a feasibility study. Colloids Surfaces A Physicochem. Eng. Asp. 217, 137-142. doi:10.1016/S0927-7757(02)00568-X

Duan, J., Gregory, J., 2003. Coagulation by hydrolysing metal salts. Adv. Colloid Interface Sci. 102, 475-502.

Ellegaard-Jensen, L., Jensen, K.A., Johansen, A., 2012. Nano-silver induces dose-response effects on the nematode Caenorhabditis elegans. Ecotoxicol. Environ. Saf. 80, 216-23. doi:10.1016/j.ecoenv.2012.03.003

Farmen, E., Mikkelsen, H.N., Evensen, O., Einset, J., Heier, L.S., Rosseland, B.O., Salbu, B., Tollefsen, K.E., Oughton, D.H., 2012. Acute and sub-lethal effects in juvenile Atlantic salmon exposed to low $\mu \mathrm{g} / \mathrm{L}$ concentrations of Ag nanoparticles. Aquat. Toxicol. 108, 7884. doi:10.1016/j.aquatox.2011.07.007

Floris, R., Nijmeijer, K., Cornelissen, E.R., 2016. Removal of aqueous nC60 fullerene from water by low pressure membrane filtration. Water Res. 91, 115-125. doi:10.1016/j.watres.2015.10.014

Gottschalk, F., Sun, T., Nowack, B., 2013. Environmental concentrations of engineered nanomaterials: review of modeling and analytical studies. Environ. Pollut. 181, 287-300. doi:10.1016/j.envpol.2013.06.003

Henry, C., Brant, J. a., 2012. Mechanistic analysis of microfiltration membrane fouling by buckminsterfullerene (C60) nanoparticles. J. Memb. Sci. 415-416, 546-557. doi:10.1016/j.memsci.2012.05.042

Hofs, B., Vries, D., Siegers, W.G., Beerendonk, E.F., Cornelissen, E.R., 2012. Influence of water type and pretreatment method on fouling and performance of an $\mathrm{Al} 2 \mathrm{O} 3$ microfiltration membrane. Desalination 299, 28-34. doi:10.1016/j.desal.2012.05.010

Huynh, K.A., Chen, K.L., 2011. Aggregation kinetics of citrate and polyvinylpyrrolidone coated silver nanoparticles in monovalent and divalent electrolyte solutions. Environ. Sci. Technol. 45, 5564-71. doi:10.1021/es200157h

Hyung, H., Kim, J.-H., 2009. Dispersion of C(60) in natural water and removal by conventional drinking water treatment processes. Water Res. 43, 2463-70. doi:10.1016/j.watres.2009.03.011 
Ladner, D., Steele, M., Weir, A., Hristovski, K., Westerhoff, P., 2012. Functionalized nanoparticle interactions with polymeric membranes. J. Hazard. Mater. 211-212, 288-95. doi:10.1016/j.jhazmat.2011.11.051

Lee, S., Bi, X.Y., Reed, R.B., Ranville, J.F., Herckes, P., Westerhoff, P., 2014. Nanoparticle Size Detection Limits by Single Particle ICP-MS for 40 Elements. Environ. Sci. Technol. 48, 10291-10300. doi:10.1021/es502422v

Liu, J., Legros, S., Hofmann, T., 2013. Natural Organic Matter Concentration and Hydrochemistry Influence Aggregation Kinetics of Functionalized Engineered Nanoparticles. Environ. Sci. Technol. 47, 4133-4120.

Liu, N., Liu, C., Zhang, J., Lin, D., 2012. Removal of dispersant-stabilized carbon nanotubes by regular coagulants. J. Environ. Sci. 24, 1364-1370. doi:10.1016/S1001-0742(11)60933-9

Mitrano, D.M., Lesher, E.K., Bednar, A., Monserud, J., Higgins, C.P., Ranville, J.F., 2012. Detecting nanoparticulate silver using single-particle inductively coupled plasma-mass spectrometry. Environ. Toxicol. Chem. 31, 115-21. doi:10.1002/etc.719

Nissinen, T.K., Miettinen, I.T., Martikainen, P.J., Vartiainen, T., 2001. Molecular size distribution of natural organic matter in raw and drinking waters. Chemosphere 45, 865-873. doi:10.1016/S0045-6535(01)00103-5

Sharifi, S., Behzadi, S., Laurent, S., Ml, F., Stroeve, P., Mahmoudi, M., 2012. Toxicity of nanomaterials. Chem. Soc. Rev. 41 VN - r, 2323-2343. doi:10.1039/c1cs15188f

Sun, Q., Li, Y., Tang, T., Yuan, Z., Yu, C.-P., 2013. Removal of silver nanoparticles by coagulation processes. J. Hazard. Mater. 261, 414-20. doi:10.1016/j.jhazmat.2013.07.066

Trzaskus, K.W., de Vos, W.M., Kemperman, A., Nijmeijer, K., 2015. Towards controlled fouling and rejection in dead-end microfiltration of nanoparticles - Role of electrostatic interactions 496, 174-184. doi:10.1016/j.memsci.2015.06.047

Vance, M.E., Kuiken, T., Vejerano, E.P., McGinnis, S.P., Hochella, M.F., Rejeski, D., Hull, M.S., 2015. Nanotechnology in the real world: Redeveloping the nanomaterial consumer products inventory. Beilstein J. Nanotechnol. 6, 1769-1780. doi:10.3762/bjnano.6.181

Wang, C., Dai, J., Shang, C., Chen, G., 2013a. Removal of aqueous fullerene nC60 from wastewater by alum-enhanced primary treatment. Sep. Purif. Technol. 116, 61-66. doi:10.1016/j.seppur.2013.05.035

Wang, C., Shang, C., Chen, G., Zhu, X., 2013b. Mechanisms of nC60 removal by the alum coagulation-flocculation-sedimentation process. J. Colloid Interface Sci. 411, 213-9. doi:10.1016/j.jcis.2013.08.023

Wang, H., Qi, J., Keller, A.A., Zhu, M., Li, F., 2014. Effects of pH , ionic strength and humic acid on the removal of TiO 2 nanoparticles from aqueous phase by coagulation. Colloids Surfaces A Physicochem. Eng. Asp. 450, 161-165. doi:10.1016/j.colsurfa.2014.03.029

Wang, Y., Westerhoff, P., Hristovski, K.D., 2012. Fate and biological effects of silver, titanium dioxide, and C(60) (fullerene) nanomaterials during simulated wastewater treatment processes. J. Hazard. Mater. 201-202, 16-22. doi:10.1016/j.jhazmat.2011.10.086 
Zhang, L., Zhao, Q., Wang, S., Mashayekhi, H., Li, X., Xing, B., 2014. Influence of ions on the coagulation and removal of fullerene in aqueous phase. Sci. Total Environ. 466-467, 6048. doi:10.1016/j.scitotenv.2013.07.077

Zhang, Y., Chen, Y., Westerhoff, P., Hristovski, K., Crittenden, J.C., 2008. Stability of commercial metal oxide nanoparticles in water. Water Res. 42, 2204-12. doi:10.1016/j.watres.2007.11.036 


\subsection{Supporting information}

Table A1 shows that filtration of the feed water through the microfiltration membranes had no effect on the water composition of the permeate, either with or without eNPs.

Table A1: Water composition before (feed) and after (permeate) filtration experiments.

\begin{tabular}{|c|c|c|c|c|c|c|}
\hline & \multicolumn{3}{|c|}{ Filtration cycle 1} & \multicolumn{3}{|c|}{ Filtration cycle 45} \\
\hline & & Permea & & & Permeat & \\
\hline & Feed & $\begin{array}{l}\text { withou } \\
\text { t eNPs }\end{array}$ & $\begin{array}{l}\text { with } \\
\text { eNPs }\end{array}$ & Feed & $\begin{array}{l}\text { without } \\
\text { eNPs }\end{array}$ & $\begin{array}{l}\text { with } \\
\text { eNPs }\end{array}$ \\
\hline $\mathrm{pH}[-]$ & 7.7 & 7.8 & 7.7 & 7.7 & 7.9 & 7.9 \\
\hline Conductivity $[\mathrm{mS} / \mathrm{m}]$ & 55.4 & 52.5 & 52.2 & 54.3 & 53.9 & 53.6 \\
\hline $\mathrm{Ca}^{2+}[\mathrm{mg} / \mathrm{l}]$ & 62.1 & 57.6 & 56.7 & 58.9 & 59.0 & 58.6 \\
\hline $\mathrm{Mg}^{2+}[\mathrm{mg} / \mathrm{l}]$ & 9.3 & 9.4 & 9.6 & 10.3 & 10.1 & 10.2 \\
\hline $\mathrm{CO}_{2}[\mathrm{mg} / \mathrm{l}]$ & 6.4 & 4.6 & 5.2 & 6.0 & 4.2 & 4.1 \\
\hline $\mathrm{HCO}^{3-}[\mathrm{mg} / \mathrm{l}]$ & 174.5 & 158.8 & 154.3 & 169.0 & 168.1 & 168.9 \\
\hline Turbidity (FTE) & 0.2 & 0.2 & 0.2 & 0.1 & 0.1 & 0.2 \\
\hline Color [mg Pt/Co/l] & 8.8 & 7.8 & 7.6 & 9.7 & 7.4 & 7.5 \\
\hline Hardness $[\mathrm{mmol} / \mathrm{l}]$ & 1.9 & 1.8 & 1.8 & 1.9 & 1.9 & 1.9 \\
\hline hardness $\left[{ }^{\circ} \mathrm{D}\right]$ & 10.8 & 10.2 & 10.1 & 10.6 & 10.6 & 10.5 \\
\hline $\mathrm{UV}[1 / \mathrm{m}]$ & 10.2 & 9.8 & 9.4 & 10.2 & 9.9 & 9.9 \\
\hline Temperature $\left[{ }^{\circ} \mathrm{C}\right]$ & 11.0 & 11.0 & 11.0 & 11.0 & 11.0 & 11.0 \\
\hline $\mathrm{DOC}[\mathrm{mg} / \mathrm{l}]$ & 4.0 & 4.3 & 4.4 & 4.0 & 4.0 & 4.0 \\
\hline
\end{tabular}





\section{Removal of AQUeOUS $\mathrm{nC}_{60}$ FULLERENE FROM WATER}

\section{BY COAGULATION,}

\section{FLOCCULATION AND}

\section{SEDIMENTATION}

This chapter has been submitted as:

Floris, R., Moser, G., Emke, E., Hofs, B., Nijmeijer, K., Cornelissen, E.R.,

Removal of aqueous $\mathrm{nC}_{60}$ fullerene from water by coagulation, flocculation and sedimentation

to Environmental Science: nano 


\begin{abstract}
A series of jar tests were performed to evaluate the removal and removal mechanism of $\mathrm{nC}_{60}$ by ferric chloride. The influence of coagulant dosage and water chemistry parameters, including natural organic matter, presence of divalent cations and solution $\mathrm{pH}$ was studied. Results from this study suggested that removal efficiency is dependent on the interactions of $\mathrm{nC}_{60}$ with the coagulant and the presence of natural organic matter and divalent cations. The removal dependency of $\mathrm{nC}_{60}$ by ferric chloride could be well correlated with the hydrolysis behaviour of $\mathrm{Fe} 3+$ in water. The removal of $\mathrm{nC}_{60}$ from pre-filtered surface water was in general higher than removal in buffered ultra-pure water. Divalent cations enhanced the removal however natural organic matter effects were found predominant at $\mathrm{pH}$ lower than 9. This is the first study that reports the simulation of coagulation flocculation and sedimentation processes of $\mathrm{nC}_{60}$ by ferric chloride coagulants.
\end{abstract}




\section{Chapter 5}

\subsection{Introduction}

Since its discovery Buckminsterfullerene $\left(\mathrm{C}_{60}\right)$ (Kroto et al., 1985) has received a considerable amount of attention due to its particular chemical and physical properties (Guldi and Prato, 2000) i.e. high hydrophobicity, heat resistance and superconductivity. Even though $\mathrm{C}_{60}$ has very high hydrophobicity $\left(\log \mathrm{K}_{\mathrm{ow}}=6.67\right.$ (Jafvert and Kulkarni, 2008) and low solubility in water (Heymann, 1996), it has been shown that in water it can form nano-sized colloidal aggregates (usually referred to as $\mathrm{nC}_{60}$ ) (Deguchi et al., 2001; Duncan et al., 2008). The wide spread and increasing use of $\mathrm{C}_{60}$ in different applications (Baena et al., 2002; Osawa, 2002) will most likely lead to the appearance of this nanomaterial in the aquatic environment (Farré et al., 2010) and consequently in drinking water sources. The toxicity of $\mathrm{C}_{60}$ to various organisms was reported in several studies (Chae et al., 2009; Fortner et al., 2005; Lyon et al., 2006; Sayes et al., 2005; Song et al., 2012). In addition $\mathrm{C}_{60}$ in water could behave as a carrier for other kinds of pollutants, such as adsorbed hydrophobic organic micropollutants or certain heavy metals (Hofmann and von der Kammer, 2009; Navarro et al., 2008; Stone et al., 2010). In this perspective, the removal of $\mathrm{nC}_{60}$ during water treatment plant operations is a priority for the production of safe drinking water. In conventional treatment plants impurities from water such as colloidal and suspended particles are usually effectively removed by coagulation and flocculation followed by sedimentation or filtration (Duan and Gregory, 2003). Coagulation involves the addition of chemical coagulants such as aluminum sulphate (referred to as alum), iron salts and/or organic polymers, resulting in the destabilization of negatively charged suspended colloids in water. Flocculation is the aggregation of destabilized particles in larger particles commonly known as flocs, which are finally removed by sedimentation and/or filtration processes. The removal of colloids and particles during coagulation/flocculation processes is generally explained in terms of two distinct mechanisms: (i) charge neutralization of negatively charged colloids by cationic hydrolysis products and (ii) incorporation of colloids and particles in an amorphous hydroxide precipitate (flocs), so called 'sweep flocculation' (Duan and Gregory, 2003).

To our knowledge only a limited number of studies dealt with the removal of engineered nanomaterials and nanoparticles (eNPs) from water by coagulation/flocculation and only a few of them focused on the removal of $\mathrm{nC}_{60}$. Removal efficiencies of eNPs by coagulation- 
flocculation-sedimentation (CFS) process were studied by several authors (Table 1). The list of eNPs studied includes $\mathrm{TiO}_{2}$ (H. Wang et al., 2013; Wang et al., 2014), $\mathrm{Fe}_{2} \mathrm{O}_{3}, \mathrm{ZnO}, \mathrm{NiO}$ (Yang Zhang et al., 2008), silica (Chang et al., 2007; Yang Zhang et al., 2008), multi-walled carbon nanotubes (CNTs) (He et al., 2012; Holbrook et al., 2010; Liu et al., 2012), quantum dots (QDs) (Y. Zhang et al., 2008), Ag (Sun et al., 2013) and $\mathrm{C}_{60}$ (Hyung and Kim, 2009; C. Wang et al., 2013a, 2013b; Lizhu Zhang et al., 2014). The removal efficiencies reported by these studies varied significantly (Table 1): the span of the removal efficiencies was $70 \%$, $80 \%$ and $90 \%$ for $\mathrm{TiO}_{2}, \mathrm{Ag}$ and CNTs respectively. Silica nanomaterials were not effectively removed (removal lower than $60 \%$ ) by poly aluminum chloride coagulation (Chang et al., 2007) nor by alum (Yang Zhang et al., 2008). Alum removal efficiency of commercial QDs (Y. Zhang et al., 2008) was about $70 \%$. 
Chapter 5

Table 5-1: Overview of research on eNPs removal by coagulation flocculation treatment.

\begin{tabular}{|c|c|c|c|c|c|c|c|}
\hline eNPs & $\begin{array}{l}\text { Concentration } \\
(\mathrm{mg} / \mathrm{l})\end{array}$ & $\begin{array}{l}\text { Coagulant } \\
\text { type }\end{array}$ & $\begin{array}{l}\text { Max } \\
\text { removal } \\
(\%)\end{array}$ & Dosage & Water type background & Parameter investigated & Refs. \\
\hline $\mathrm{Ag}$ & 1 & AS & 99 & $495 \mathrm{mg} / \mathrm{l}$ & Buffered ultrapure water & $\mathrm{pH}, \mathrm{NOM}$, Cations, SS & $\begin{array}{l}\text { (Sun et al., } \\
\text { 2013) }\end{array}$ \\
\hline $\mathrm{Ag}$ & 1 & $\mathrm{FC}$ & 97 & $400 \mathrm{mg} / \mathrm{l}$ & Buffered ultrapure water & $\mathrm{pH}, \mathrm{NOM}$, Cations, SS & $\begin{array}{l}\text { (Sun et al., } \\
\text { 2013) }\end{array}$ \\
\hline $\mathrm{Ag}$ & 1 & PAC & 90 & $30 \mathrm{mg} / \mathrm{l}$ & Buffered ultrapure water & $\mathrm{pH}, \mathrm{NOM}$, Cations, SS & $\begin{array}{l}\text { (Sun et al., } \\
\text { 2013) }\end{array}$ \\
\hline $\mathrm{Ag}$ & 1 & PFS & 78 & $47 \mathrm{mg} / \mathrm{l}$ & Buffered ultrapure water & $\mathrm{pH}, \mathrm{NOM}$, Cations, SS & $\begin{array}{l}\text { (Sun et al., } \\
\text { 2013) }\end{array}$ \\
\hline $\mathrm{Ag}$ & 1 & AS & 99 & $495 \mathrm{mg} / \mathrm{l}$ & Buffered ultrapure water & $\mathrm{pH}, \mathrm{NOM}$, Cations, SS & $\begin{array}{l}\text { (Sun et al., } \\
\text { 2013) }\end{array}$ \\
\hline $\mathrm{Ag}$ & 1 & $\mathrm{FC}$ & 80 & $400 \mathrm{mg} / \mathrm{l}$ & Buffered ultrapure water & $\mathrm{pH}, \mathrm{NOM}$, Cations, SS & $\begin{array}{l}\text { (Sun et al., } \\
\text { 2013) }\end{array}$ \\
\hline $\mathrm{Ag}$ & 1 & PAC & 20 & $30 \mathrm{mg} / \mathrm{l}$ & Buffered ultrapure water & $\mathrm{pH}, \mathrm{NOM}$, Cations, SS & $\begin{array}{l}\text { (Sun et al., } \\
2013 \text { ) }\end{array}$ \\
\hline $\mathrm{Ag}$ & 1 & PFS & 20 & $47 \mathrm{mg} / \mathrm{l}$ & Buffered ultrapure water & $\mathrm{pH}, \mathrm{NOM}$, Cations, SS & $\begin{array}{l}\text { (Sun et al., } \\
\text { 2013) }\end{array}$ \\
\hline $\mathrm{Ag}$ & 1 & AS & 85 & 495 mg/l & Buffered ultrapure water & $\mathrm{pH}, \mathrm{NOM}$, Cations, SS & $\begin{array}{l}\text { (Sun et al., } \\
\text { 2013) }\end{array}$ \\
\hline $\mathrm{Ag}$ & 1 & $\mathrm{FC}$ & 97 & $400 \mathrm{mg} / \mathrm{l}$ & Buffered ultrapure water & $\mathrm{pH}, \mathrm{NOM}$, Cations, SS & $\begin{array}{l}\text { (Sun et al., } \\
\text { 2013) }\end{array}$ \\
\hline $\mathrm{Ag}$ & 1 & PAC & 75 & $30 \mathrm{mg} / \mathrm{l}$ & Buffered ultrapure water & $\mathrm{pH}, \mathrm{NOM}$, Cations, SS & $\begin{array}{l}\text { (Sun et al., } \\
\text { 2013) }\end{array}$ \\
\hline
\end{tabular}


Removal of Engineered Nanoparticles in Drinking Water Treatment Processes

\begin{tabular}{|c|c|c|c|c|c|c|c|}
\hline $\mathrm{Ag}$ & 1 & PFS & 80 & $47 \mathrm{mg} / \mathrm{l}$ & Buffered ultrapure water & pH, NOM, Cations, SS & $\begin{array}{l}\text { (Sun et al., } \\
\text { 2013) }\end{array}$ \\
\hline $\mathrm{Ag}$ & 1 & AS & 98 & $495 \mathrm{mg} / \mathrm{l}$ & Buffered ultrapure water & pH, Kaolin, NOM, Cations, SS & $\begin{array}{l}\text { (Sun et al., } \\
\text { 2013) }\end{array}$ \\
\hline $\mathrm{Ag}$ & 1 & $\mathrm{FC}$ & 98 & $400 \mathrm{mg} / \mathrm{l}$ & Buffered ultrapure water & pH, Kaolin, NOM, Cations, SS & $\begin{array}{l}\text { (Sun et al., } \\
2013 \text { ) }\end{array}$ \\
\hline $\mathrm{Ag}$ & 1 & PAC & 98 & $30 \mathrm{mg} / \mathrm{l}$ & Buffered ultrapure water & pH, Kaolin, NOM, Cations, SS & $\begin{array}{l}\text { (Sun et al., } \\
\text { 2013) }\end{array}$ \\
\hline $\mathrm{Ag}$ & 1 & PFS & 90 & $47 \mathrm{mg} / \mathrm{l}$ & Buffered ultrapure water & pH, Kaolin, NOM, Cations, SS & $\begin{array}{l}\text { (Sun et al., } \\
2013 \text { ) }\end{array}$ \\
\hline $\mathrm{C}_{60}$ & 1 & AS & 99 & $100 \mathrm{mg} / \mathrm{l}$ & Buffered ultrapure water & $\mathrm{pH}$, alkalinity, NOM & $\begin{array}{l}\text { (Hyung and } \\
\text { Kim, 2009) }\end{array}$ \\
\hline $\mathrm{C}_{60}$ & 4 & AS & 90 & $0.02 \mathrm{mM}$ & Deionized water & $\begin{array}{l}\mathrm{pH} \text {, zeta potential, ions, } \\
\text { alkalinity, HA }\end{array}$ & $\begin{array}{l}\text { (Lizhu Zhang } \\
\text { et al., 2014) }\end{array}$ \\
\hline $\mathrm{C}_{60}$ & 0.2 & AS & 90 & $50 \mathrm{mg} / \mathrm{l}$ & Ultrapure water & $\mathrm{pH}$ & $\begin{array}{l}\text { (C. Wang et } \\
\text { al., 2013b) }\end{array}$ \\
\hline $\mathrm{C}_{60}$ & 0.2 & AS & 95 & $75 \mathrm{mg} / \mathrm{l}$ & Filtered saline wastewater & $\begin{array}{l}\mathrm{pH} \text {, alkalinity, } \mathrm{SS}, \mathrm{OM} \text { and } \\
\text { salinity }\end{array}$ & $\begin{array}{l}\text { (C. Wang et } \\
\text { al., 2013a) }\end{array}$ \\
\hline HA-CNTs & $10.9-21.8$ & $\mathrm{FC}$ & 50 & $0.27 \mathrm{uM}$ as $\mathrm{Fe}$ & Ultrapure water & $\begin{array}{l}\text { Kaolin, OM, alginate, Stab. } \\
\text { Meth. }\end{array}$ & $\begin{array}{l}\text { (Holbrook et } \\
\text { al., 2010) }\end{array}$ \\
\hline HA-CNTs & $10.9-21.8$ & AS & 50 & $0.29 \mathrm{uM}$ as $\mathrm{Al}$ & Ultrapure water & $\begin{array}{l}\text { Kaolin, OM, alginate, Stab. } \\
\text { Meth. }\end{array}$ & $\begin{array}{l}\text { (Holbrook et } \\
\text { al., 2010) }\end{array}$ \\
\hline NAQ-CNTs & $10.9-21.8$ & $\mathrm{FC}$ & 80 & $0.27 \mathrm{uM}$ as $\mathrm{Fe}$ & Ultrapure water & $\begin{array}{l}\text { Kaolin, OM, alginate, Stab. } \\
\text { Meth. }\end{array}$ & $\begin{array}{l}\text { (Holbrook et } \\
\text { al., 2010) }\end{array}$ \\
\hline NAQ-CNTs & $10.9-21.8$ & AS & 90 & $0.07 \mathrm{uM}$ as $\mathrm{Al}$ & Ultrapure water & $\begin{array}{l}\text { Kaolin, OM, alginate, Stab. } \\
\text { Meth. }\end{array}$ & $\begin{array}{l}\text { (Holbrook et } \\
\text { al., 2010) }\end{array}$ \\
\hline
\end{tabular}


Chapter 5

\begin{tabular}{|c|c|c|c|c|c|c|c|}
\hline HA-CNTs & $0.5,1,5$ & $\mathrm{FC}$ & 80 & $0.3 \mathrm{mM}$ as $\mathrm{Fe}$ & Ultrapure water & Flocs structure characteristics & $\begin{array}{l}\text { (He et al., } \\
2012 \text { ) }\end{array}$ \\
\hline TA-CNTs & 80 & AS, PAC & 92 & $2.78 \mathrm{mg} \mathrm{Al}^{3+} / 1$ & Ultrapure water & Dispersant agent & $\begin{array}{l}\text { (Liu et al., } \\
\text { 2012) }\end{array}$ \\
\hline HA-CNTs & 80 & AS, PAC & 79 & $5.56 \mathrm{mg} \mathrm{Al}^{3+} / 1$ & Ultrapure water & Dispersant agent & $\begin{array}{l}\text { (Liu et al., } \\
\text { 2012) }\end{array}$ \\
\hline SDBS-CNTs & 80 & AS, PAC & 99 & $2.78 \mathrm{mg} \mathrm{Al}^{3+} / 1$ & Ultrapure water & Dispersant agent & $\begin{array}{l}\text { (Liu et al., } \\
\text { 2012) }\end{array}$ \\
\hline TX100-CNTs & 80 & AS, PAC & 21 & $0.22 \mathrm{mg} \mathrm{Al}^{3+} / 1$ & Ultrapure water & Dispersant agent & $\begin{array}{l}\text { (Liu et al., } \\
2012 \text { ) }\end{array}$ \\
\hline CTAB-CNTs & 80 & AS, PAC & 0 & - & Ultrapure water & Dispersant agent & $\begin{array}{l}\text { (Liu et al., } \\
\text { 2012) }\end{array}$ \\
\hline $\mathrm{Fe}_{2} \mathrm{O}_{3}$ & 10 & AS & 38 & $60 \mathrm{mg} / \mathrm{l}$ & Buffered ultrapure water & Electrolyte concentration & $\begin{array}{l}\text { (Yang Zhang } \\
\text { et al., 2008) }\end{array}$ \\
\hline Latex nps & 10 & $\mathrm{FC}$ & - & $0.25-15 \mathrm{mg} / \mathrm{l}$ & Ultrapure water & $\mathrm{pH}$, zeta potential & $\begin{array}{l}\text { (Oriekhova } \\
\text { and Stoll, } \\
\text { 2014) }\end{array}$ \\
\hline $\mathrm{NiO}$ & 10 & AS & 25 & $40 \mathrm{mg} / \mathrm{l}$ & Buffered ultrapure water & Electrolyte concentration & $\begin{array}{l}\text { (Yang Zhang } \\
\text { et al., 2008) }\end{array}$ \\
\hline Silica & 10 & AS & 60 & $20 \mathrm{mg} / \mathrm{l}$ & Buffered ultrapure water & Electrolyte concentration & $\begin{array}{l}\text { (Yang Zhang } \\
\text { et al., 2008) }\end{array}$ \\
\hline Silicate & - & PAC & - & & Pre-treated waste water & - & $\begin{array}{l}\text { (Chang et al., } \\
\text { 2007) }\end{array}$ \\
\hline QDs & 13.66 & AS & $>90$ & $1.43 \mathrm{meq} \mathrm{Al}^{3+}$ & Buffered ultrapure water & Cations & $\begin{array}{l}\text { (Y. Zhang et } \\
\text { al., 2008) }\end{array}$ \\
\hline QDs & 13.66 & AS & 80 & 2.86 meq $\mathrm{Al}^{3+} 1$ & Tap water & Cations & $\begin{array}{l}\text { (Y. Zhang et } \\
\text { al., 2008) }\end{array}$ \\
\hline
\end{tabular}


Removal of Engineered Nanoparticles in Drinking Water Treatment Processes

\begin{tabular}{|c|c|c|c|c|c|c|c|}
\hline $\mathrm{TiO}_{2}$ & 30 & PFS & 90 & $\begin{array}{l}0.3 \mathrm{mM} \text { as } \\
\mathrm{Fe}^{3+}\end{array}$ & Buffered de-ionized water & $\mathrm{pH}, \mathrm{IS}, \mathrm{HA}$ & $\begin{array}{l}\text { (Wang et al., } \\
\text { 2014) }\end{array}$ \\
\hline $\mathrm{TiO}_{2}$ & 30 & $\mathrm{FC}$ & 78 & $\begin{array}{l}0.3 \mathrm{mM} \text { as } \\
\mathrm{Fe}^{3+}\end{array}$ & Buffered de-ionized water & $\mathrm{pH}, \mathrm{IS}, \mathrm{HA}$ & $\begin{array}{l}\text { (Wang et al., } \\
\text { 2014) }\end{array}$ \\
\hline $\mathrm{TiO}_{2}$ & 30 & $\mathrm{FC}$ & 57 & $60 \mathrm{mg} / \mathrm{l}$ & Tap water & IS and ion type, alkalinity, HA & $\begin{array}{l}\text { (H. Wang et } \\
\text { al., 2013) }\end{array}$ \\
\hline $\mathrm{TiO}_{2}$ & 30 & PFS & 77 & $79 \mathrm{mg} / \mathrm{l}$ & Tap water & IS and ion type, alkalinity, HA & $\begin{array}{l}\text { (H. Wang et } \\
\text { al., 2013) }\end{array}$ \\
\hline $\mathrm{TiO}_{2}$ & 30 & PAC & 28 & $51 \mathrm{mg} / \mathrm{l}$ & Tap water & IS and ion type, alkalinity, HA & $\begin{array}{l}\text { (H. Wang et } \\
\text { al., 2013) }\end{array}$ \\
\hline $\mathrm{TiO}_{2}$ & 30 & AS & 32 & $102 \mathrm{mg} / \mathrm{l}$ & Tap water & IS and ion type, alkalinity, HA & $\begin{array}{l}\text { (H. Wang et } \\
\text { al., 2013) }\end{array}$ \\
\hline $\mathrm{TiO}_{2}$ & 10 & AS & 50 & $40 \mathrm{mg} / \mathrm{l}$ & Buffered ultrapure water & Electrolyte concentration & $\begin{array}{l}\text { (Yang Zhang } \\
\text { et al., 2008) }\end{array}$ \\
\hline $\mathrm{TiO}_{2}$ & 10 & AS & 78 & $40 \mathrm{mg} / \mathrm{l}$ & Buffered ultrapure water & Electrolyte concentration & $\begin{array}{l}\text { (Yang Zhang } \\
\text { et al., 2008) }\end{array}$ \\
\hline $\mathrm{ZnO}$ & 10 & AS & 50 & $20 \mathrm{mg} / \mathrm{l}$ & Buffered ultrapure water & Electrolyte concentration & $\begin{array}{l}\text { (Yang Zhang } \\
\text { et al., 2008) }\end{array}$ \\
\hline
\end{tabular}

Abbreviations: HA: humic acid; $N A Q$ : Nanosperse $\mathrm{AQ}^{\circledR}$; $n p s$ : nanoparticles; $T A$ : tannic acid; SDBS: sodium dodecyl benzenesulfonate; TX100 polyethylene glycol octylphenyl ether; $C T A B$ cetyltrimethyl ammonium bromide; $P F S$ : polyferric sulphate; $F C$ : ferric chloride; $A S$ : aluminium sulphate; PAC: poly aluminium chloride; $I S$ : ionic strength; $S S$ : suspended solid. 
The removal efficiency of eNPs and its variation depends on the eNPs colloidal stability, thus on water chemistry, eNP type and concentration and coagulant type and dosage. The removal efficiency dependency on water chemistry was found in agreement with previous studies on eNPs stability in water (Chen et al., 2010). The presence of electrolytes influences the size of the eNPs because of electrical double layer compression (Yang Zhang et al., 2008) enhancing destabilization and aggregation. Increasing electrolyte concentration improved the removal rate of $\mathrm{TiO}_{2}$ nanoparticles (Wang et al., 2014). Similarly, at pH 8.5 an increased ionic strength during coagulation with $0.08 \mathrm{mM} \mathrm{Al}^{3+}$ (due to the addition of salts such as $\mathrm{NaCl}$ or $\mathrm{CaCl}_{2}$ ) caused the electric double layer to be compressed, which enhanced $\mathrm{nC}_{60}$ aggregation up to an ionic strength of about 3-4 mM (Lizhu Zhang et al., 2014). The presence of humic acid (HA) greatly decreased the removal rate of $\mathrm{TiO}_{2}$ (Wang et al., 2014) and $\mathrm{nC}_{60}$ (Hyung and Kim, 2009) because of the steric hindrance effects of HA molecules on nanoparticles and the additional negative charge imparted to the nanoparticles. A similar conclusion was drawn in other studies on coagulation of $\mathrm{TiO}_{2}$ (H. Wang et al., 2013) and Ag (Sun et al., 2013) by 4 different coagulants (alum, ferric chloride, polyaluminum chloride, polyferric sulfate) independently on coagulant type. Alkalinity positively affected $\mathrm{nC}_{60}$ removal during alum coagulation (Hyung and Kim, 2009). Even though in the case of $\mathrm{TiO}_{2}$ coagulation it was also reported that too high $\left(\mathrm{NaHCO}_{3}>0.03 \mathrm{M}\right)$ or too low $\left(\mathrm{NaHCO}_{3}<0.001 \mathrm{M}\right)$ alkalinity was unfavorable for the removal efficiency of eNPs (Holbrook et al., 2010; H. Wang et al., 2013). Water chemistry parameters (alkalinity, electrolyte and natural organic matter (NOM) concentration) were found to be of secondary importance with respect to coagulant type (and dosage) and to the stabilization method used (e.g. surfactant type) (Holbrook et al., 2010).

Comparing results from above mentioned studies (Table 1) it appears that also the interactions between a specific eNP type and coagulant type play an important role in CFS processes. When metal salts such as alum and ferric chloride are used as coagulants, the water $\mathrm{pH}$ also plays an important role on the removal efficiency. The effect of $\mathrm{pH}$ on the removal is related to particular hydrolysis of the coagulants and ultimately to the interaction between the eNPs and the hydrolysis products (H. Wang et al., 2013). Alum outperformed ferric chloride as a coagulant in removing CNTs at circumneutral pH (Holbrook et al., 2010). Despite this, polyferric sulfate and ferric chloride gave higher removal efficiencies of $\mathrm{TiO}_{2}$ 
than alum and polyaluminum chloride (H. Wang et al., 2013). Four regular coagulants, including aluminum sulfate, ferric chloride, polyaluminum chloride and polyferric sulphate, were efficient in removing Ag nanomaterials from water up to 99\% (aluminum sulphate and ferric chloride), $90 \%$ (polyaluminum chloride) and less than $80 \%$ (polyferric sulphate) (Sun et al., 2013). However, the two chloride coagulants were recommended by the authors because they could also reduce the silver ion concentrations.

These studies offer an important insight into the removal of eNPs from water by CFS processes. At the same time, they highlight difficulties in predicting removal efficiencies of unknown combinations of eNPs and coagulants. In this context removal efficiencies of $\mathrm{nC}_{60}$ have been studied only by few authors (Hyung and Kim, 2009; C. Wang et al., 2013a, 2013b; Lizhu Zhang et al., 2014) using only alum as coagulant, which has different coagulation and flocculation behavior than ferric chloride. In this study we investigate the removal of $\mathrm{nC}_{60}$ from water by coagulation with ferric chloride a widely used coagulant in water and waste water treatment (Duan and Gregory, 2003) that has not previously been investigated for the removal of $\mathrm{nC}_{60}$. A series of jar tests were performed to evaluate the removal and removal mechanism of $\mathrm{nC}_{60}$ by ferric chloride, in which the influence of coagulant dosage, and water chemistry parameters including natural organic matter, presence of divalent cations and solution $\mathrm{pH}$ was studied. This investigation was conducted under both controlled conditions (buffered ultra-pure water matrix) and natural occurring conditions (surface water and pretreated surface water matrix).

\subsection{Theory}

Coagulation/flocculation using ferric chloride in water treatment processes is achieved by two distinct mechanisms: 1) charge neutralization of negatively charged colloids by cationic hydrolysis products and 2) incorporation of impurities in a precipitate (Duan and Gregory, 2003). When dissolved in water, ferric chloride undergoes hydrolysis resulting in different hydrolysis species (also referred to as hydrolysis products) that have a low solubility, and subsequently form a mostly amorphous ferric hydroxide precipitate (Figure 5-1). 


\section{Chapter 5}

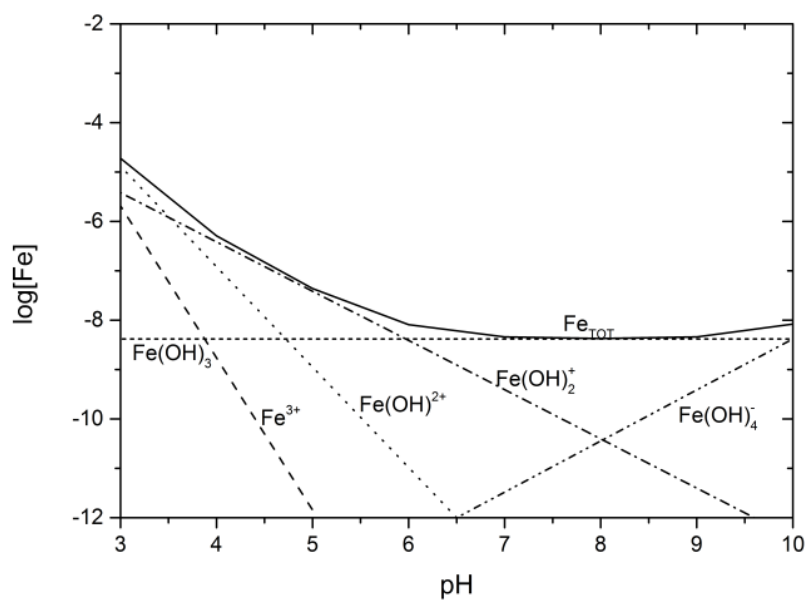

Figure 5-1: $\log \left[\mathrm{Fe}^{3+}\right]-p H$ solubility diagram at zero ionic strength and $25{ }^{\circ} \mathrm{C}$. The solubility constants of the various species are obtained from Duan and Gregory, 2003.

The amorphous ferric hydroxide $\mathrm{Fe}(\mathrm{OH})_{3}$ has very low solubility $\left(\mathrm{K}_{\mathrm{s}}=4 \times 10^{-38}\right.$ (Duan and Gregory, 2003) and thus a precipitate is formed at all relevant dosages for water treatment. Consequentially sweep flocculation is the dominant removal mechanism of colloidal and suspended particles in water treatment. Even so, as the operational $\mathrm{pH}$ conditions change, other removal mechanisms, such as neutralization of the charge of the colloids by adsorption of counter ions on the surface of the colloid and inter-colloid bridging, can contribute to the removal of impurities from water. At $\mathrm{pH}<6$ the positively charged metal ions enhance the removal efficiency destabilizing negatively charged colloids, particles and natural organic matter. Meanwhile at $\mathrm{pH}>9, \mathrm{Fe}^{3+}$ hydrolysis products are high molecular weight polymers or sols, which efficiently remove particles through bridging and sweep flocculation (Yan et al., 2008). 


\subsection{Materials and methods}

\subsubsection{Reagents and chemicals}

Fullerene- $\mathrm{C}_{60}$ (purity >99.5\%) was obtained from Sigma Aldrich (Steinheim, Germany). Toluene was purchased from Mallinckrodt Baker B.V. (Deventer, the Netherlands). Ferric chloride $\mathrm{FeCl}_{3} 40 \%$ w/w solution was obtained from Boom BV (Meppel, the Netherlands). Lewatit VPOC 1071 type (Lanxess, Germany) heterodisperse anion exchange gel type resins were used for NOM removal. The anion exchange (AIEX) resins are based on a polyacrylamide backbone functionalized with quaternary amine (type I) groups. The average AIEX resin size is $0.55 \mathrm{~mm}$ and the resin density is $1.09 \mathrm{~g} / \mathrm{ml}$. Lewatit MonoPlus S 108 (Lanxess, Germany) monodisperse cation exchange resins were used for $\mathrm{Ca}^{2+}(\mathrm{aq})$ and $\mathrm{Mg}^{2+}(\mathrm{aq})$ removal. The cation exchange (CIEX) resins are based on a styrene-divinyl benzene copolymer. The average CIEX resin size is $0.65 \mathrm{~mm}$ and the resin density is $0.79 \mathrm{~g} / \mathrm{ml}$. Before use, both AIEX and CIEX resins were pre-rinsed and regenerated according to a procedure described by (Cornelissen et al., 2010). Briefly, $500 \mathrm{~g}$ of resin was rinsed for $12 \mathrm{~h}$ in 12.51 of tap water. Afterwards the resin was filtered and then mixed in 151 of $\mathrm{NaCl} 10 \% \mathrm{w} / \mathrm{w}$ solution during $2 \mathrm{~h}$ for regeneration.

\subsubsection{Preparation and characterization of fullerene suspensions}

Stable aqueous $\mathrm{nC}_{60}$ nanoparticle suspensions were prepared using a solvent exchange/sonication procedure (Chen and Elimelech, 2007). Briefly, $50 \mathrm{mg}$ of $\mathrm{C}_{60}$ fullerene powder was added to $100 \mathrm{~mL}$ toluene and was stirred for at least $12 \mathrm{~h}$ to achieve complete dissolution of the fullerenes. The $\mathrm{C}_{60}$ solution was added to $350 \mathrm{ml}$ ultrapure water (18.2 $\mathrm{M} \Omega \cdot \mathrm{cm}$ ) in a $600 \mathrm{ml}$ beaker. Toluene was evaporated in a sonication bath (Branson) at an energy intensity of $125 \mathrm{~W}$. Ultrapure water was regularly added each hour to compensate for the volume loss due to toluene evaporation and to avoid fullerene deposition. The resulting colloidal suspension was finally filtered through a 0.45 and $0.22 \mu \mathrm{m}$ cellulose acetate vacuum filter system (Corning Amsterdam, the Netherlands). This procedure was repeated 6 times 


\section{Chapter 5}

resulting in stock solution concentrations of $15-20 \mathrm{mg} / \mathrm{l}$. The obtained stock solution was diluted afterwards in four different water types to reach a final concentration of $0.1 \mathrm{mg} / \mathrm{l}$.

Characterization of the $\mathrm{nC}_{60}$ stock solution was performed with a set of different analytical techniques. The actual formation of the colloidal suspensions was proven by UV-VIS spectrophotometer. The $\mathrm{nC}_{60}$ UV/VIS absorption spectrum of the feed solution displayed two typical peaks at 250 and $360 \mathrm{~nm}$ (not shown here), as was observed before (Jung et al., 2013). Concentrations of $\mathrm{nC}_{60}$ suspensions were measured after liquid-liquid extraction with toluene (Emke et al., 2015) by using normal-phase liquid chromatography coupled to high-resolution mass spectrometry and UV spectrophotometry (HPLC-UV-MS-UV) employing an atmospheric pressure photoionisation (APPI) interface(Emke et al., 2015). External standards in toluene were analysed to determine the concentration. Due to the range of concentrations two approaches were used: Concentrations ranging from 0.1-128 $\mu \mathrm{g} / \mathrm{l}$ were quantified by using the accurate molecular ion of $\mathrm{C}_{60}(720.00055 \mathrm{~m} / \mathrm{z})$; For everything above $128 \mu \mathrm{g} / \mathrm{l}$ quantification was done by UV $(255 \mathrm{~nm})$. The zeta potential of the suspension was -42.8 $\mathrm{mV} \pm 1.33$ (Floris et al., 2015) This high zeta potential was also reported in several previous studies (Brant et al., 2005; Chen and Elimelech, 2009), indicates a high stability of the suspension.

\subsubsection{Water types}

To understand the role of water quality parameters on the removal of $\mathrm{nC}_{60}$ by ferric chloride as coagulant, CFS experiments were performed with $\mathrm{nC}_{60}$ dispersed in 4 different water types. Water types used were: ultrapure water buffered by $0.97 \mathrm{~g} / \mathrm{C} \mathrm{CO}_{3}{ }^{2-}$, pre-filtered surface water, anion exchange pre-treated surface water and cation exchange pre-treated surface water. Ultrapure water was obtained by purifying demineralized water in a Milli-Q system (Millipore, Bedford, MA). The three different pre-treated water types were obtained from the same surface water batch collected from the Lek canal (Nieuwegein, the Netherlands) prior to the Amsterdam Water Supply Dunes (AWDs) uptake. Pre-filtered surface water was obtained by filtering the raw water through a $0.45 \mu \mathrm{m}$ cartridge. Anion and cation exchange pre-treated surface water were obtained by a procedure consisting of stirring 251 of filtered surface water with $500 \mathrm{~g}$ of resins for $24 \mathrm{~h}$. The three pre-treated water types were stored until 
use (maximum 2 weeks) in the dark at $4{ }^{\circ} \mathrm{C}$ to minimize changes in the water composition before the experiments. The water compositions of the filtered surface water and anion and cation exchange water treated were determined by Vitens Laboratory (Leeuwarden, the Netherlands) and are given in Table 2.

The $\mathrm{pH}$ of the water matrix did not change after pre-treatment. After the pre-filtration step the water analysis showed a low content of suspended solid $(<1 \mathrm{mg} / \mathrm{l})$ and a low turbidity ( $\sim 0.2$ FTE). DOC was $\sim 2 \mathrm{mg} / \mathrm{l}$, the bulk parameters that indicate the content of organic matter present in the water. The pre-filtered surface water presents a content of divalent cations that classified the water as fairly hard (10-11 $\left.{ }^{\circ} \mathrm{D}\right)$ according the U.S. Geological Survey. Anion exchange treatment reduced the NOM content with $\sim 70 \%$ : the initial DOC of $2.2 \mathrm{mg} / \mathrm{l}$ was reduced to $0.6 \mathrm{mg} / 1$, which has been shown to be mainly due to the removal of the humic substance fraction of the total NOM (Cornelissen et al., 2010). Cation exchange treatment almost completely removed divalent cations with removal values higher than $99 \%$ making the water from fairly hard $\left(11.1^{\circ} \mathrm{D}\right)$ to soft $\left(<0.1^{\circ} \mathrm{D}\right)$.

Table 5-2: Water quality parameters of the 4 water types.

\begin{tabular}{lllll}
\hline Water parameter & $\begin{array}{l}\text { Buffered } \\
\text { ultrapure } \\
\text { water }\end{array}$ & $\begin{array}{l}\text { Pre-filtered } \\
\text { surface } \\
\text { water }\end{array}$ & $\begin{array}{l}\text { AIEX } \\
\text { treated }\end{array}$ & $\begin{array}{l}\text { CIEX } \\
\text { treated }\end{array}$ \\
\hline pH & 8.66 & 8.29 & 7.81 & 8.41 \\
Conductivity $(\boldsymbol{\mu S} / \mathbf{c m})$ & 1269 & 699 & 1560 & 1035 \\
turbidity [FTE] & n.m. & 0.2 & 0.2 & 0.18 \\
Suspended solid $[\mathbf{m g} / \mathbf{l}]$ & n.m. & $<1$ & $<1$ & $<1$ \\
Calcium $\left(\mathbf{C a}^{2+}\right)[\mathbf{m g} / \mathbf{l}]$ & n.m. & 61.3 & 61.3 & $<0.5$ \\
Magnesium $\left(\mathbf{M g}{ }^{2+}\right)[\mathbf{m g} / \mathbf{l}]$ & n.m. & 10.2 & 8.72 & $<0.1$ \\
Total hardness $[\mathbf{m m o l} / /]$ & n.m. & 1.97 & 1.89 & $<0.02$ \\
Total hardness $\left[{ }^{\circ} \mathbf{D}\right]$ & n.m. & 11.1 & 10.6 & $<0.1$ \\
DOC $(\mathbf{m g} / \mathbf{l})$ & n.m. & 2.2 & 0.6 & 2.8 \\
\hline
\end{tabular}

Abbreviations: n.m.: not measured. 


\subsubsection{Simulation of the coagulation-flocculation-sedimentation processes}

The ferric chloride coagulation-flocculation-sedimentation $\left(\mathrm{CFS}_{\mathrm{Fe}}\right)$ process was simulated by laboratory tests using a jar test apparatus. The jar test apparatus consists of six identical beakers of 21 , each equipped with two dosing units and a stirrer paddle. The stirrer paddles are driven by one common motor that provide the same mixing energy to the six beakers. The procedure started by adjusting the $\mathrm{pH}$ to the initial set-points, ranging from 4 to 9 by the injection of and adequate amount of $0.1 \mathrm{M} \mathrm{NaOH}$ or $0.1 \mathrm{M} \mathrm{HCl}$, followed by a rapid mixing phase (400 rpm for 10 seconds). Then coagulation was simulated by rapid mixing (400 rpm for another 10 seconds) after dosage of the ferric chloride. Flocculation was simulated by a slow mixing phase (70 rpm for 15 minutes) and the sedimentation step by a 30 minutes deposition phase without mixing. Afterwards samples of the supernatant were taken at a depth of $2 \mathrm{~cm}$. Samples were analysed by LC-MS-UV to measure the $\mathrm{nC}_{60}$ concentration. The removal efficiency was calculated from Equation 1:

$$
R=\left(1-\frac{C_{f}}{C_{i}}\right) \times 100
$$

Where $\mathrm{C}_{\mathrm{f}}$ is the concentration in the supernatant after $\mathrm{CFS}_{\mathrm{Fe}}$ and $\mathrm{C}_{\mathrm{i}}$ is the initial concentration of the $\mathrm{nC}_{60}$ dispersion. To evaluate the settling efficiency of the flocs after $\mathrm{CFS}_{\mathrm{Fe}}$, the residual turbidity of the supernatant samples was measured by a turbidity meter (Hach). Jar tests were conducted at 3 ferric chloride dosages: 5,10 and $15 \mathrm{mg} / \mathrm{l}$ commonly used in practice. Experiments in ultra-pure water were conducted by adding $\mathrm{NaHCO}_{3}$ in solution to obtain an alkalinity of $0.97 \mathrm{~g} / \mathrm{l} \mathrm{CO}_{3}{ }^{2-}$ to ensure enough buffering capacity during the $\mathrm{Fe}^{3+}$ hydrolysis. Two duplicate jar tests were performed for each dosage condition and water type using the same $\mathrm{nC}_{60}$ dilution batch. 


\subsection{Results and discussion}

\subsubsection{Removal efficiency on ultrapure water}

Before investigating the effect of $\mathrm{NOM}$ and divalent cations, coagulation of $\mathrm{nC}_{60}$ was studied in ultrapure water. Control experiments without ferric chloride were also performed to estimate possible adsorption in the jar test installation. The effect of $\mathrm{pH}$ and $\mathrm{FeCl}_{3}$ dosage on the removal of $\mathrm{nC}_{60}$ in ultrapure water is shown in Figure 5-2.

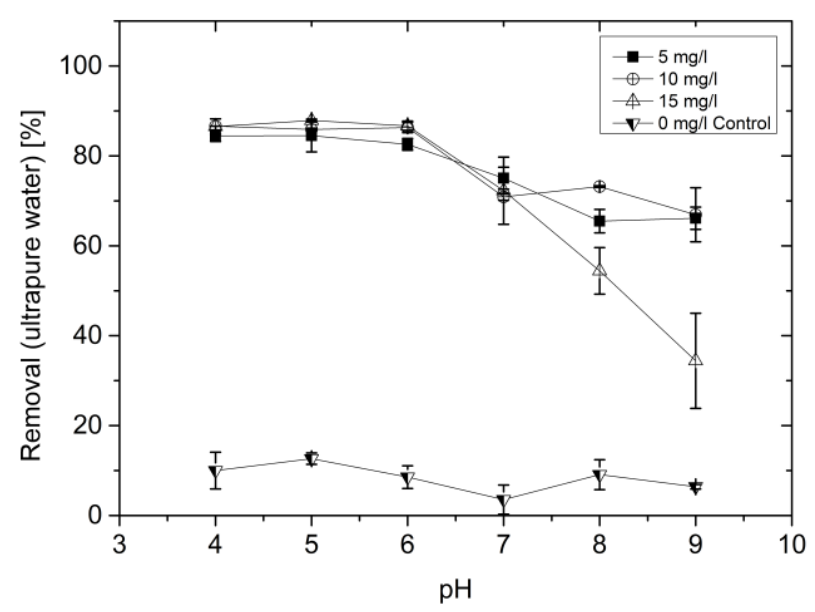

Figure 5-2: Effect of $\mathrm{pH}$ and coagulant dosage (in $\mathrm{mg} / \mathrm{l} \mathrm{Fe}^{3+}$ ) on the removal efficiency of ${ }_{n} C_{60}(0.09 \pm 0.02 \mathrm{mg} / \mathrm{l})$ in ultra-pure water buffered by $0.97 \mathrm{~g} / \mathrm{CO}_{3}{ }^{2-}$. 


\section{Chapter 5}

Under acidic conditions $(\mathrm{pH}<6)$ the removal efficiency was higher than $80 \%$, independent of the coagulant dosage.

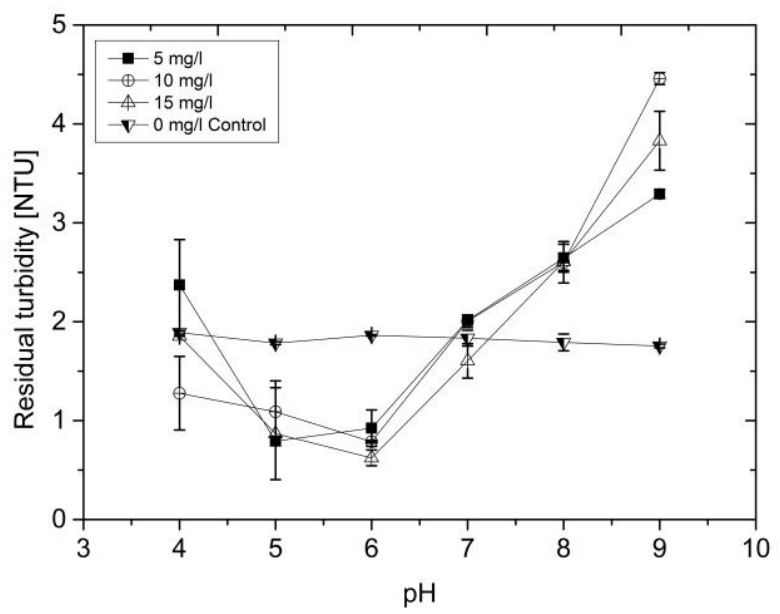

Figure 5-3: Effect of $\mathrm{pH}$ and coagulant dosage on the residual turbidity after coagulationflocculation-sedimentation of $\mathrm{n}_{60}(0.09 \pm 0.02 \mathrm{mg} / \mathrm{l})$ in ultra-pure water buffered by $0.97 \mathrm{~g} / \mathrm{l}$ $\mathrm{CO}_{3}{ }^{2-}$.

This is in agreement with the lower residual turbidity values (Figure 5-3) compared to the values of the control experiments measured in the same $\mathrm{pH}$ range. At neutral $\mathrm{pH}$, the removal for all 3 dosages decreased to $\sim 70 \%$ and the residual turbidity was similar to the level of the control experiment ( 2 NTU). Under alkaline conditions $(\mathrm{pH}>7)$ the removal efficiency decreased and stabilized at $60-70 \%$ for the 5 and $10 \mathrm{mg} / \mathrm{l}$ dosages. In the case of $15 \mathrm{mg} / \mathrm{l}$ the removal efficiency decreased with increasing $\mathrm{pH}$ until a value of $34 \pm 11 \%$ was reached, suggesting re-stabilization effects due to the high amount of coagulant (Siéliéchi et al., 2008). The residual turbidity increased with an increase of the $\mathrm{pH}$ to values higher than the control experiment for all dosages. This shows a lower settleability of the flocs formed at higher $\mathrm{pH}$, which was also corroborated by visual observation (Figure 5-4). 


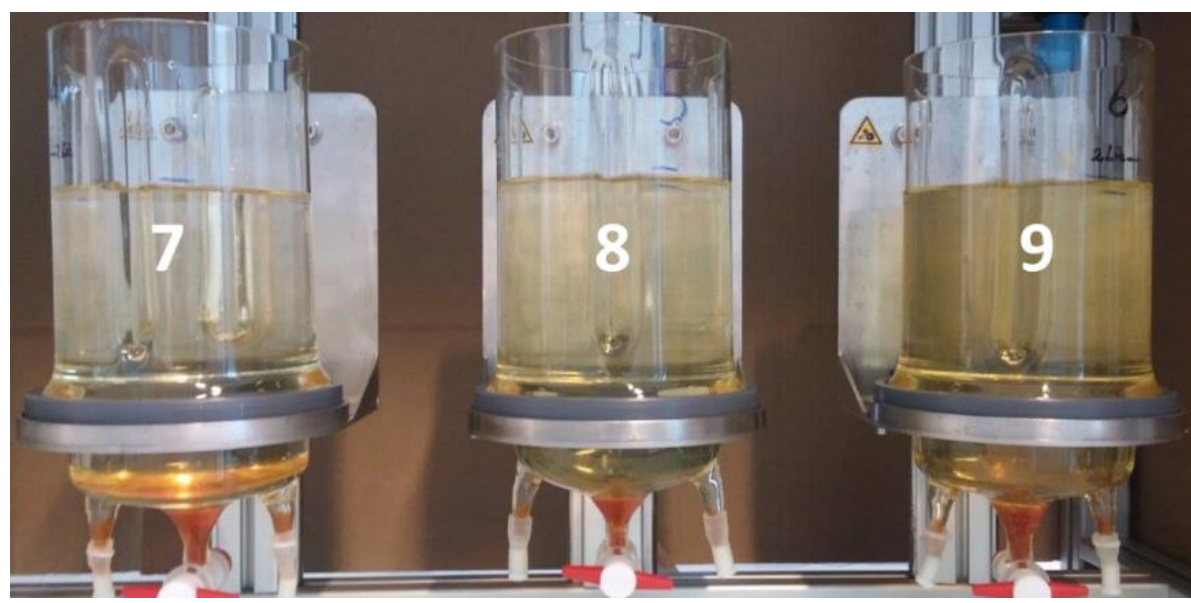

Figure 5-4: Visual observation of residual turbidity and flocs settleability at pH 7 (left), 8 (centre) and 9 (right), after coagulation-flocculation-sedimentation of $n_{60}$ in ultra-pure water at $15 \mathrm{mg} / \mathrm{l}$ dosage of coagulant.

These results highlight the importance of the $\mathrm{pH}$ on the $\mathrm{nC}_{60}$ removal efficiency in buffered ultrapure water. The results correspond to the different hydrolysis products of iron in equilibrium with the amorphous uncharged hydroxide precipitate (Figure 5-1) and on the characteristics and settle ability of the flocs formed during the process. Around $\mathrm{pH} 4$ the relevant hydrolysis products of ferric chloride are a mixture of $\mathrm{Fe}^{3+}, \mathrm{FeOH}^{2+}$ and $\mathrm{Fe}(\mathrm{OH})_{2}^{+}$, which enhances the removal efficiency by destabilizing the negatively charged $\mathrm{nC}_{60}$. In this region, sweep flocculation and charge neutralization contribute to the removal of $\mathrm{nC}_{60}$ from ultrapure water. At higher $\mathrm{pH}$, the balance shifts from the more highly charged cationic hydrolysis products towards $\mathrm{Fe}(\mathrm{OH})_{2}{ }^{+}$and $\mathrm{Fe}(\mathrm{OH})_{3}$, and at high pH ultimately to $\mathrm{Fe}(\mathrm{OH})_{4}{ }^{-}$. As a consequence of these changes in the hydrolysis species distribution, at $\mathrm{pH}>7 \mathrm{nC}_{60}$ removal can only be explained by sweep flocculation. The fact that charge neutralization is not occurring in this $\mathrm{pH}$ region explains the decrease in the removal efficiency. Comparing these results with removal efficiencies of $\mathrm{nC}_{60}$ by coagulation with alum in ultrapure water (Hyung and Kim, 2009; Wang et al., 2013b), at the dosage of $10 \mathrm{mg} / \mathrm{l}, \mathrm{FeCl}_{3}$ and alum reached comparable removal at the $\mathrm{pH}$ range $7-8$ (Hyung and Kim, 2009). At lower $\mathrm{pH}$ $(\mathrm{pH}<6)$ the removal by $\mathrm{FeCl}_{3}$ was considerably higher (up to $50 \%$ more). In acidic conditions comparable removal was reached only at 50 and $75 \mathrm{mg} / \mathrm{l}$ alum dosage of alum coagulant (C. Wang et al., 2013a). These differences are related to the different hydrolysis behaviour of 


\section{Chapter 5}

aluminium and iron (Duan and Gregory, 2003) and confirm the importance of the particular interaction between eNPs and coagulant used during the $\mathrm{CFS}_{\mathrm{Fe}}$ processes.

\subsubsection{Removal efficiency on pre-filtered surface water}

The effect of $\mathrm{pH}$ and $\mathrm{FeCl}_{3}$ dosage on the removal of $\mathrm{nC}_{60}$ dispersed in pre-filtered surface water is shown in Figure 5-5.

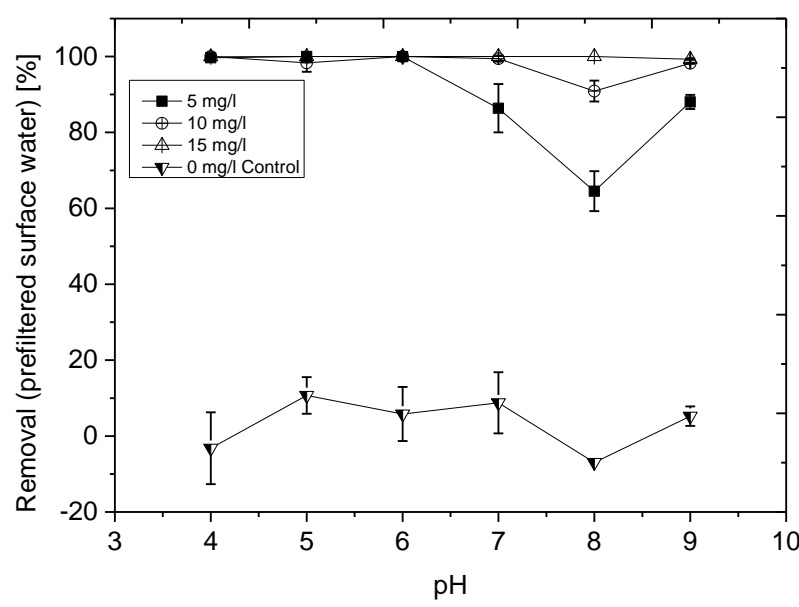

Figure 5-5: Effect of $\mathrm{pH}$ and coagulant dosage (in $\mathrm{mg} / \mathrm{l} \mathrm{Fe}^{3+}$ ) on the removal of $n \mathrm{C}_{60}$ dispersed in pre-filtered surface water.

Under acidic conditions $(\mathrm{pH} \leq 6)$ the removal is almost complete $(\sim 100 \%)$ within the dosage range investigated and removal efficiencies are significantly higher than those in ultrapure water. Different factors can contribute to the increase in the removal efficiency: (i) additional charge neutralization and destabilization due to the presence of about $2 \mathrm{mM}$ of multivalent cations (mostly $\mathrm{Ca}^{2+}$ and $\mathrm{Mg}^{2+}$ ) in the pre-filtered surface water, (ii) the presence of about 2 $\mathrm{mg} / \mathrm{l} \mathrm{NOM}$ which enhances the destabilization effect of divalent cations on $\mathrm{nC}_{60}$ (Lu-qing Zhang et al., 2014), (iii) co-precipitation of $\mathrm{nC}_{60}$ with $\mathrm{NOM}$ at the optimum $\mathrm{pH}$ condition for NOM removal by ferric salts $(\mathrm{pH}<6)$ (Yan et al., 2008).

At the lowest $\mathrm{FeCl}_{3}$ dosage $(5 \mathrm{mg} / \mathrm{l})$ in pre-filtered surface water the removal efficiency sharply decreased to $86 \%$ and $65 \%$ at $\mathrm{pH} 7$ and 8 respectively and increased again to around 
$90 \%$ at $\mathrm{pH}$ 9. A similar behaviour was observed for the medium $\mathrm{FeCl}_{3}$ dosage (10 mg/l) but with a minimum removal of $90 \%$ at around $\mathrm{pH} 7.5$. At high dosage of ferric chloride (15 $\mathrm{mg} / \mathrm{l}$ ) a nearly complete removal efficiency of $\mathrm{nC}_{60}$ was observed over the complete $\mathrm{pH}$ range investigated. At $\mathrm{pH}$, higher than the optimum $\mathrm{pH}$ condition for $\mathrm{NOM}$ removal $(\mathrm{pH}>6)$ the decrease in the removal can be correlated to the interactions of $\mathrm{nC}_{60}-\mathrm{NOM}$ in the water. This can increase electrostatic and steric repulsions among $\mathrm{nC}_{60}$ aggregates, thereby facilitating dispersion and stabilization of $\mathrm{nC}_{60}$ in water (Chen and Elimelech, 2007) hampering the removal of $\mathrm{nC}_{60}$. Higher removal efficiencies achieved at $\mathrm{pH} 9$ are attributed to the presence of calcium and magnesium in 3 different ways: (i) by the formation and consequent precipitation of metal hydroxide products due to the reaction of iron with calcium and magnesium ions (Crittenden et al., 2005; Metcalf and Eddy, 2003; Reynolds and Richards, 1996), (ii) by bridging effects between high molecular weight polymers resulting by the hydrolysis of $\mathrm{Fe}^{3+}$ at high $\mathrm{pH}$ (Yan et al., 2008) thus improving the sweep flocculation removal, (iii) by high $\mathrm{pH}$ induced flocculation of magnesium hydroxide and calcium carbonate (Vandamme et al., 2012) which lead to sweep flocculation of $\mathrm{CaCO}_{3}$ and $\mathrm{Mg}(\mathrm{OH})_{2}$ (Leentvaar and Rebhun, 1982).

\subsubsection{The role of NOM and divalent cations}

$\mathrm{CFS}_{\mathrm{Fe}}$ experiments with $\mathrm{nC}_{60}$ dispersed in AIEX and CIAX pre-treated surface water were conducted to investigate the role of the negatively charged fraction of NOM and divalent cations $\left(\mathrm{Ca}^{2+}\right.$ and $\left.\mathrm{Mg}^{2+}\right)$ on the removal efficiency. The removal of $\mathrm{nC}_{60}$ was investigated with the same coagulant dosage (5-10-15 mg/l) but for a smaller $\mathrm{pH}$ range (6-9). Only the results for a coagulant dosage of $5 \mathrm{mg} / \mathrm{FeCl}_{3}$ are reported, as for higher dosages the observed differences were smaller (Figure 5-6). 


\section{Chapter 5}

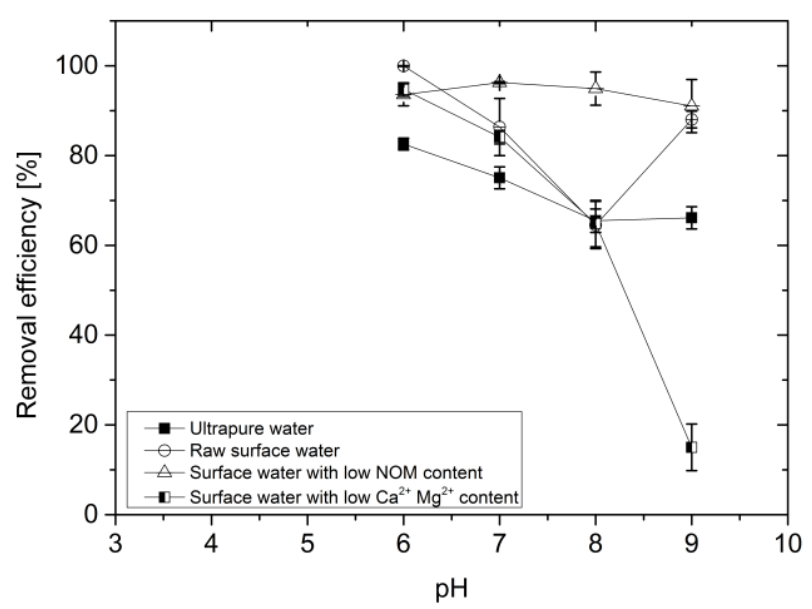

Figure 5-6: Effect of NOM and divalent cations $\left(\mathrm{Ca}^{2+}\right.$ and $\left.\mathrm{Mg}^{2+}\right)$ on the removal of $n \mathrm{C}_{60}$ dispersed in 3 different types of pre-treated surface water at a coagulant dosage of $5 \mathrm{mg} /$.

Over all the $\mathrm{pH}$ and dosage range investigated, a lower content of NOM in the water results in higher removal efficiency. This corroborates the NOM stabilization effects at $\mathrm{pH}$ higher than 6 due to electrostatic and steric repulsion effects of the negatively charged NOM on $\mathrm{nC}_{60}$ aggregates. From the removal of $\mathrm{nC}_{60}$ at $5 \mathrm{mg} / \mathrm{l}$ coagulant dose obtained with pre-filtered surface water, it seems that the effect of NOM stabilization dominates at $\mathrm{pH} 7$ and 8.

The presence of divalent cations (water hardness) has virtually no effect in the $\mathrm{pH}$ range 6-8 where NOM stabilization effects dominates, compared to the use of pre-filtered surface water. At $\mathrm{pH} 9$ the effect of hardness becomes visible and the removal efficiency changes considerably: in the absence of $\mathrm{Ca}^{2+}$ and $\mathrm{Mg}^{2+}$ the removal observed is negligible and only 10 to $20 \%$, whilst in pre-filtered surface water the removal is up $90 \%$. This is attributed to bridging effects (Yan et al., 2008), metal hydroxide formation and calcium carbonate precipitation (Vandamme et al., 2012) which enhance the floc formation and floc precipitation (Leentvaar and Rebhun, 1982). 
To verify the occurrence of co-precipitation between $\mathrm{NOM}$ and $\mathrm{nC}_{60}, \mathrm{CFS}_{\mathrm{Fe}}$ experiments were performed with surface water without $\mathrm{nC}_{60}$. The removal of $\mathrm{NOM}$ was evaluated by the ultraviolet absorbance (UVA) at $254 \mathrm{~nm}\left(\mathrm{UVA}_{254}\right)$ (Chin et al., 1994). Results are reported in Figure 5-7.

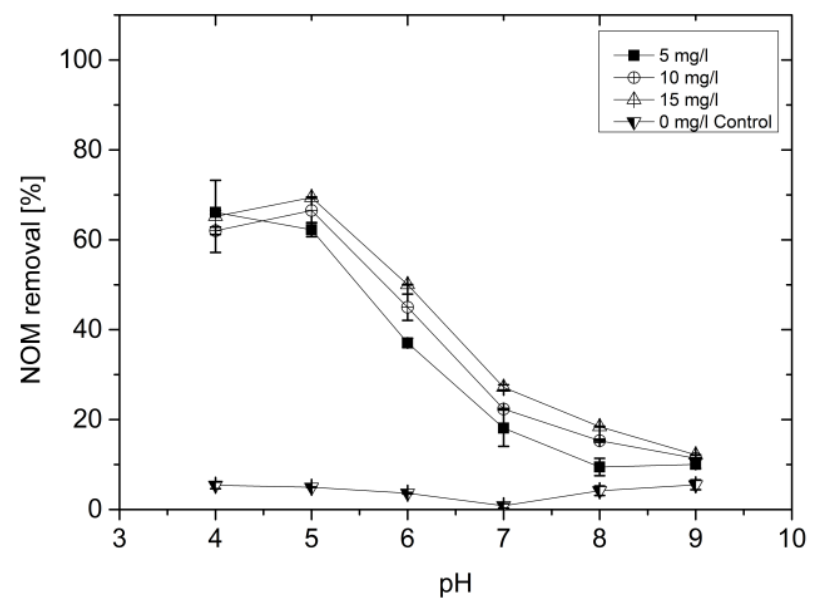

Figure 5-7: Influence of $\mathrm{pH}$ and coagulant dosage on the removal of NOM by ferric chloride in surface water. NOM removal evaluated by the UV absorbance at $254 \mathrm{~nm}$.

The control experiment without the addition of coagulant shows no or little removal $(\mathrm{R}<$ $10 \%$ ) of NOM. This excludes NOM adsorption on the jar test installation or NOM precipitation due to changes in the solution $\mathrm{pH}$ (Jiang and Wang, 2009). In the presence of coagulant, the removal of NOM is dependent on $\mathrm{pH}$ and the trend is comparable to the removal of $\mathrm{nC}_{60}$ reported in Figure 5-5 and 5-6. Optimal NOM removal is obtained at $\mathrm{pH}$ lower than 5 (Jiang and Wang, 2009) meanwhile NOM removal constantly decreases at higher $\mathrm{pH}$ values. The similar trends shown in the removal efficiency with $\mathrm{pH}$ suggest that co-precipitation between the two occurs in the optimum $\mathrm{pH}$ range for NOM removal, while for higher $\mathrm{pH}$ the presence of $\mathrm{NOM}$ hinders the removal efficiency of $\mathrm{nC}_{60}$ by electrostatic and steric repulsions. 


\section{Chapter 5}

\subsection{Conclusions}

The removal of $\mathrm{nC}_{60}$ by coagulation, flocculation and sedimentation with ferric chloride was investigated in buffered ultra-pure water, pre-filtered surface water and pre-filtered surface water without multivalent cations or with the negatively charged part of NOM removed.

The $\mathrm{nC}_{60}$ removal by $\mathrm{FeCl}_{3}$ dosage in buffered ultra-pure water appeared different from results obtained in literature with alum coagulant and confirm the importance of the particular interaction between eNPs and coagulant type. The removal dependency of $\mathrm{nC}_{60}$ from buffered ultra-pure water by $\mathrm{FeCl}_{3}$ as a function of $\mathrm{pH}$ (maximum $85 \%$ at low $\mathrm{pH}$, but down to $34 \%$ at $\mathrm{pH} 9$ and $15 \mathrm{mg} / \mathrm{FeCl}_{3}$ ) was well correlated with the hydrolysis behaviour of $\mathrm{Fe}^{3+}$ in water. At acidic conditions, cationic hydrolysis products greatly enhanced the removal performance of the $\mathrm{CFS}_{\mathrm{Fe}}$ process by charge neutralization and destabilization.

The removal of $\mathrm{nC}_{60}$ from pre-filtered surface water by $\mathrm{CFS}_{\mathrm{Fe}}$ was in general higher than removal in buffered ultra-pure water being high $(\sim 100 \%)$ at acidic conditions and no dependent on coagulant dosage.

Pre-filtered surface water was pre-treated with AIEX or CIEX, to remove the negatively charged part of the NOM and multivalent cations, respectively, which could both be causing the observed higher removal. It was found that $\mathrm{NOM}$ enhances the removal of $\mathrm{nC}_{60}$ at acidic condition and decreases the efficiency of the $\mathrm{CFS}_{\mathrm{Fe}}$ process at the $\mathrm{pH}$ range $6-8$, probably due to co-precipitation and $\mathrm{nC}_{60}$ steric hindrance, respectively. Also, the presence of $\mathrm{Ca}^{2+}$ and $\mathrm{Mg}^{2+}$ seems to contribute to the removal at acidic conditions by charge neutralization and destabilization. At $\mathrm{pH}$ between 6 and 9 the presence of $\mathrm{NOM}$ governs the $\mathrm{CFS}_{\mathrm{Fe}}$ process stabilizing the $\mathrm{nC}_{60}$ and inhibiting its removal efficiency. Removing the negatively charged part of the $\mathrm{NOM}$ content resulted in high $\mathrm{nC}_{60}$ removal at all dosage and $\mathrm{pH}$ investigated. Divalent cations content increased the removal of $\mathrm{nC}_{60}$ by $\mathrm{CFS}_{\mathrm{Fe}}$ at $\mathrm{pH} 9$ overcoming the NOM stabilization and increasing the removal up to $90 \%$.

These results confirmed the importance of the particular interaction between nanomaterial and coagulant type and the role of NOM and cations content on these interactions. $\mathrm{CFS}_{\mathrm{Fe}}$ is a good option for the removal of $\mathrm{nC}_{60}$ dispersed in real surface water but particular attention 
must be paid to the specific water composition and $\mathrm{pH}$ operation conditions in order to insure the complete removal of $\mathrm{nC}_{60}$ during the production of drinking water.

\section{Acknowledgement}

This research was sponsored by the Joint Research Programme of KWR Watercycle Research Institute for the Dutch Drinking Water Companies and supported by NanoNextNL, a micro and nanotechnology consortium of the Government of the Netherlands and 130 partners. 


\section{Chapter 5}

\section{References}

Baena, J.R., Gallego, M., Valca, M., Division, A.C., 2002. Fullerenes in the analytical sciences. Trends Anal. Chem. 21, 187-198.

Brant, J., Lecoanet, H., Hotze, M., Wiesner, M., 2005. Comparison of electrokinetic properties of colloidal fullerenes (nC60) formed using two procedures. Environ. Sci. Technol. 39, 6343-51.

Chae, S.-R., Wang, S., Hendren, Z., Wiesner, M., Watanabe, Y., Gunsch, C., 2009. Effects of fullerene nanoparticles on Escherichia coli K12 respiratory activity in aqueous suspension and potential use for membrane biofouling control. J. Memb. Sci. 329, 68-74. doi:10.1016/j.memsci.2008.12.023

Chang, M.R., Lee, D.J., Lai, J.Y., 2007. Nanoparticles in wastewater from a science based industrial park Coagulation using polyaluminum chloride. J. Environ. Manage. 85, 10091014. doi:10.1016/j.jenvman.2006.11.013

Chen, K.L., Elimelech, M., 2009. Relating colloidal stability of fullerene (C60) nanoparticles to nanoparticle charge and electrokinetic properties. Environ. Sci. Technol. 43, 7270-6.

Chen, K.L., Elimelech, M., 2007. Influence of humic acid on the aggregation kinetics of fullerene (C60) nanoparticles in monovalent and divalent electrolyte solutions. J. Colloid Interface Sci. 309, 126-134.

Chen, K.L., Smith, B. a., Ball, W.P., Fairbrother, D.H., 2010. Assessing the colloidal properties of engineered nanoparticles in water: case studies from fullerene C 60 nanoparticles and carbon nanotubes. Environ. Chem. 7, 10. doi:10.1071/EN09112

Chin, Y.-P., Aiken, G., O’Loughlin, E., 1994. Molecular Weight, Polydispersity, and Spectroscopic Properties of Aquatic Humic Substances. Environ. Sci. Technol. 28, 18531858.

Cornelissen, E.R., Chasseriaud, D., Siegers, W.G., Beerendonk, E.F., Kooij, D. Van Der, 2010. Effect of anionic fluidized ion exchange (FIX) pre-treatment on nanofiltration (NF) membrane fouling. Water Res. 44, 3283-3293. doi:10.1016/j.watres.2010.03.007

Deguchi, S., Alargova, R.G., Tsujii, K., 2001. Stable Dispersions of Fullerenes , C 60 and C 70 , in Water . Preparation and Characterization. Langmuir 17, 6013-6017.

Duan, J., Gregory, J., 2003. Coagulation by hydrolysing metal salts. Adv. Colloid Interface Sci. $102,475-502$.

Duncan, L.K., Jinschek, J.R., Vikesland, P.J., 2008. C60 colloid formation in aqueous systems: effects of preparation method on size, structure, and surface charge. Environ. Sci. Technol. 42, 173-8.

Emke, E., Sanchís, J., Farré, M., Bäuerlein, P.S., Voogt, P. De, 2015. Environmental Science Nano Determination of several fullerenes in sewage water by LC HR-MS using atmospheric pressure photoionisation. Environ. Sci. Nano. doi:10.1039/C4EN00133H 
Farré, M., Pérez, S., Gajda-schrantz, K., Osorio, V., Kantiani, L., Ginebreda, A., Barceló, D., 2010. First determination of C60 and C70 fullerenes and N-methylfulleropyrrolidine C60 on the suspended material of wastewater effluents by liquid chromatography hybrid quadrupole linear ion trap tandem mass spectrometry. J. Hydrol. 383, 44-51. doi:10.1016/j.jhydrol.2009.08.016

Floris, R., Nijmeijer, K., Cornelissen, E.R., 2015. Removal of aqueous nC60 fullerene from water by low pressure membrane filtration. Water Res. in press.

Fortner, J.D., Lyon, D.Y., Sayes, C.M., Boyd, a M., Falkner, J.C., Hotze, E.M., Alemany, L.B., Tao, Y.J., Guo, W., Ausman, K.D., Colvin, V.L., Hughes, J.B., 2005. C60 in water: nanocrystal formation and microbial response. Environ. Sci. Technol. 39, 4307-16.

Guldi, D., Prato, M., 2000. Excited-State Properties of C60 Fullerene Derivatives. Acc. Chem. Res. 33, 695-703. doi:10.1021/ar990144m

He, M., Zhou, R., Guo, X., 2012. Behavior of stabilized multiwalled carbon nanotubes in a $\mathrm{FeCl} 3$ coagulation system and the structure characteristics of the produced flocs. J. Colloid Interface Sci. 366, 173-8. doi:10.1016/j.jcis.2011.09.059

Heymann, D., 1996. Solubility of Fullerenes C60 and C70 in Seven Normal Alcohols and Their Deduced Solubility in Water. Fuller. Sci. Technol. 4, 543-544.

Hofmann, T., von der Kammer, F., 2009. Estimating the relevance of engineered carbonaceous nanoparticle facilitated transport of hydrophobic organic contaminants in porous media. Environ. Pollut. 157, 1117-26. doi:10.1016/j.envpol.2008.10.022

Holbrook, R.D., Kline, C.N., Filliben, J.J., 2010. Impact of source water quality on multiwall carbon nanotube coagulation. Environ. Sci. Technol. 44, 1386-91. doi:10.1021/es902946j

Hyung, H., Kim, J.-H., 2009. Dispersion of C(60) in natural water and removal by conventional drinking water treatment processes. Water Res. 43, 2463-70. doi:10.1016/j.watres.2009.03.011

Jafvert, C.T., Kulkarni, P.P., 2008. Buckminsterfullerene's (C60) octanol-water partition coefficient (Kow) and aqueous solubility. Environ. Sci. Technol. 42, 5945-5950.

Jiang, J., Wang, H., 2009. Comparative Coagulant Demand of Polyferric Chloride and Ferric Chloride for the Removal of Humic Acid Comparative Coagulant Demand of Polyferric Chloride and Ferric Chloride for the Removal of Humic Acid. Sep. Sci. Technol. 44. doi:10.1080/01496390802590020

Jung, Y.K., Kim, M.J., Kim, Y.-J., Kim, J.Y., 2013. Limitation of UV-Vis absorption analysis for determination of aqueous colloidal fullerene (nC60) at high ionic strength. KSCE J. Civ. Eng. 17, 51-59. doi:10.1007/s12205-013-1738-2

Kroto, H.W., Heath, J.R., O’Brien, S.C., Curl, R.F., Smalley, R.E., 1985. C60: Buckminsterfullerene. Nature 318, 162.

Leentvaar, J., Rebhun, M., 1982. Effect of magnesium a $\mathrm{n}$ d calcium precipitation on coagulation-flocculation with lime. Water Res. 16, 655-662.

Liu, N., Liu, C., Zhang, J., Lin, D., 2012. Removal of dispersant-stabilized carbon nanotubes by regular coagulants. J. Environ. Sci. 24, 1364-1370. doi:10.1016/S1001-0742(11)60933-9 


\section{Chapter 5}

Lyon, D.Y., Adams, L.K., Falkner, J.C., Alvarezt, P.J.J., 2006. Antibacterial activity of fullerene water suspensions: effects of preparation method and particle size. Environ. Sci. Technol. 40, 4360-6.

Navarro, E., Baun, A., Behra, R., Hartmann, N.B., Filser, J., Miao, A.-J., Quigg, A., Santschi, P.H., Sigg, L., 2008. Environmental behavior and ecotoxicity of engineered nanoparticles to algae, plants, and fungi. Ecotoxicology 17, 372-86. doi:10.1007/s10646-008-0214-0

Oriekhova, O., Stoll, S., 2014. Investigation of FeCl3 induced coagulation processes using electrophoretic measurement, nanoparticle tracking analysis and dynamic light scattering: Importance of $\mathrm{pH}$ and colloid surface charge. Colloids Surfaces A Physicochem. Eng. Asp. 461, 212-219. doi:10.1016/j.colsurfa.2014.07.049

Osawa, E., 2002. Perspective of Fullerene Nanotechnology. Berlin, Germany.

Sayes, C.M., Gobin, A.M., Ausman, K.D., Mendez, J., West, J.L., Colvin, V.L., 2005. NanoC60 cytotoxicity is due to lipid peroxidation. Biomaterials 26, 7587-95. doi:10.1016/j.biomaterials.2005.05.027

Siéliéchi, J.-M., Lartiges, B.S., Kayem, G.J., Hupont, S., Frochot, C., Thieme, J., Ghanbaja, J., Caillerie, J.B. d'Espinose de la, Barre`s, O., Kamga, R., Levitz, P., Michota, L.J., 2008. Changes in humic acid conformation during coagulation with ferric chloride: Implications for drinking water treatment , lie. Water Res. 42, 2111-2123. doi:10.1016/j.watres.2007.11.017

Song, M., Yuan, S., Yin, J., Wang, X., Meng, Z., Wang, H., Jiang, G., 2012. Size-dependent toxicity of nano-C60 aggregates: more sensitive indication by apoptosis-related Bax translocation in cultured human cells. Environ. Sci. Technol. 46, 3457-64. doi:10.1021/es2039008

Stone, V., Nowack, B., Baun, A., van den Brink, N., Kammer, F. Von Der, Dusinska, M., Handy, R., Hankin, S., Hassellöv, M., Joner, E., Fernandes, T.F., 2010. Nanomaterials for environmental studies: classification, reference material issues, and strategies for physicochemical characterisation. Sci. Total Environ. 408, 1745-54. doi:10.1016/j.scitotenv.2009.10.035

Sun, Q., Li, Y., Tang, T., Yuan, Z., Yu, C.-P., 2013. Removal of silver nanoparticles by coagulation processes. J. Hazard. Mater. 261, 414-20. doi:10.1016/j.jhazmat.2013.07.066

Vandamme, D., Foubert, I., Fraeye, I., Meesschaert, B., Muylaert, K., 2012. Flocculation of Chlorella vulgaris induced by high $\mathrm{pH}$ : Role of magnesium and calcium and practical implications. Bioresour. Technol. 105, 114-119. doi:10.1016/j.biortech.2011.11.105

Wang, C., Dai, J., Shang, C., Chen, G., 2013a. Removal of aqueous fullerene nC60 from wastewater by alum-enhanced primary treatment. Sep. Purif. Technol. 116, 61-66. doi:10.1016/j.seppur.2013.05.035

Wang, C., Shang, C., Chen, G., Zhu, X., 2013b. Mechanisms of nC60 removal by the alum coagulation-flocculation-sedimentation process. J. Colloid Interface Sci. 411, 213-9. doi:10.1016/j.jcis.2013.08.023 
Wang, H., Qi, J., Keller, A.A., Zhu, M., Li, F., 2014. Effects of pH , ionic strength and humic acid on the removal of TiO 2 nanoparticles from aqueous phase by coagulation. Colloids Surfaces A Physicochem. Eng. Asp. 450, 161-165. doi:10.1016/j.colsurfa.2014.03.029

Wang, H., Ye, Y., Qi, J., Li, F., Tang, Y., 2013. Removal of titanium dioxide nanoparticles by coagulation: effects of coagulants, typical ions, alkalinity and natural organic matters. Water Sci. Technol. 68, 1137-1143. doi:10.2166/wst.2013.356

Yan, M., Wang, D., Qu, J., Ni, J., Chow, C., 2008. Enhanced coagulation for high alkalinity and micro-polluted water: The third way through coagulant optimization. Water Res. 42, 2278-2286. doi:10.1016/j.watres.2007.12.006

Zhang, L., Zhang, Y., Lin, X., Yang, K., Lin, D., 2014. The role of humic acid in stabilizing fullerene C60 suspensions. J. Zhejiang Univ. 15, 634-642. doi:10.1631/jzus.A1400115

Zhang, L., Zhao, Q., Wang, S., Mashayekhi, H., Li, X., Xing, B., 2014. Influence of ions on the coagulation and removal of fullerene in aqueous phase. Sci. Total Environ. 466-467, 6048. doi:10.1016/j.scitotenv.2013.07.077

Zhang, Y., Chen, Y., Westerhoff, P., Crittenden, J.C., 2008. Stability and Removal of Water Soluble CdTe Quantum Dots in Water. Environ. Sci. Technol. 42, 321-325.

Zhang, Y., Chen, Y., Westerhoff, P., Hristovski, K., Crittenden, J.C., 2008. Stability of commercial metal oxide nanoparticles in water. Water Res. 42, 2204-12. doi:10.1016/j.watres.2007.11.036 
6 Removal of aqueous

$\mathrm{nC}_{60}$ FULLERENE FROM WATER

BY ADSORPTION ON

POWDERED AND GRANULAR

ACTIVATED CARBON 


\begin{abstract}
The potential presence and the associated health risk of engineered nanoparticles in water resources, makes their removal mandatory for safe drinking water production. Here is presented an experimental investigation on the potential of activated carbon treatment in removing $\mathrm{nC}_{60}$ fullerene nanoparticles from aqueous dispersions. Aspects associated with the activated carbon form (powder and granular) and the water background were investigated conducting isotherm and column experiments. Isotherm experiments showed that powder activated carbon was able to remove $\mathrm{nC}_{60}$ only at relatively high dosage and long contact time, while the granular form was inefficient removing these nanoparticles. Additional column tests conducted with granular activated carbon seem to suggest that under conditions more representative for water treatment applications (filtration of the $\mathrm{nC}_{60}$ dispersion through a GAC fixed-bed column), the retention of $\mathrm{nC}_{60}$ by $\mathrm{GAC}$ can be considerable.
\end{abstract}




\section{Chapter 6}

\subsection{Introduction}

Engineered nanoparticles (eNPs), such as carbon-based buckminsterfullerene $\left(\mathrm{C}_{60}\right)$ (Kroto et al., 1985), are one of the most used engineered nanomaterials (Baena et al., 2002; Osawa, 2002). They have been widely applied in different applications, e.g. cosmetics (Reisch, 2009), biological and medical applications (Bakry et al., 2007; Jensen et al., 1996) and plastic solar cells (Brabec et al., 2001). $\mathrm{C}_{60}$ nanoparticles in water can form nano-sized colloidal aggregates often termed as $\mathrm{nC}_{60}$ (Deguchi et al., 2001). The wide spread and increasing use of these eNPs already lead to the appearance of $\mathrm{nC}_{60}$ in the aquatic environment (Farre et al., 2010) and consequently is expected to be found in drinking water sources in the future as well. The presence of eNPs and particularly $\mathrm{nC}_{60}$ will pose several challenges to water utilities in providing safe drinking water: firstly, $\mathrm{nC}_{60}$ is toxic to various organisms (Chae et al., 2009; Lyon et al., 2006; Sayes et al., 2005; Song et al., 2012), and secondly, $\mathrm{nC}_{60}$ in water was found to behave as a carrier for other kinds of pollutants, such as adsorbed hydrophobic organic micropollutants (Baun et al., 2008; Hofmann and von der Kammer, 2009; Musee, 2011; Navarro et al., 2008; Stone et al., 2010; Xie et al., 2008; Yang et al., 2006; Zhang et al., 2014). Therefore, the removal of $\mathrm{nC}_{60}$ and its removal mechanisms in water treatment plants is essential to safeguard the existing water treatment processes and to produce clean and safe drinking water minimizing human exposure to $\mathrm{nC}_{60}$ via ingestion.

Activated carbon (AC) adsorption is a very frequently applied water treatment process to remove different types of impurities, most notably apolar organic compounds. Despite that, while the effectiveness of conventional treatments, such as coagulation and flocculation (Hyung and Kim, 2009; Wang et al., 2013a, 2013b; Zhang et al., 2014), and advanced treatments, such as membrane filtration (Floris et al., 2016; Henry and Brant, 2012; Henry et al., 2012), in removing $\mathrm{nC}_{60}$ from water has been investigated, so far the removal effectiveness of $\mathrm{nC}_{60}$ using $\mathrm{AC}$ treatment has not received considerable attention. Most probably because removal of nanomaterials in drinking water treatment plants is still at the very early stage.

$\mathrm{AC}$ is a common term used to describe carbon-based materials that contain a well-developed internal pore structure. AC has been recognized as one of the most popular and widely used adsorbent materials in water and wastewater treatment (Bhatnagar et al., 2013). It is an apolar 
material that combines a high surface area (ranges from 500 to $1500 \mathrm{~m}^{2} / \mathrm{g}$ ), a large porosity, a well-developed internal pore structure that make it an effective adsorbent for the removal of a wide variety of organic pollutants (i.e. pesticides, pharmaceuticals, (Rivera-Utrilla et al., 2011), and specific organic compounds that cause taste and odour problems or are of health concern (Edzwald, 2011; McKay et al., 1985).

Next to high surface area and porosity, another important characteristic that makes AC a good adsorbent in water treatment processes, is the possibility to impart a polar character to the $\mathrm{AC}$ by ionization of acidic and basic functional groups present on AC surface. Ionization of functional groups is dependent on water $\mathrm{pH}$ and imparts surface charge to the AC allowing the adsorption of polar contaminants by electrostatic interaction forces (Yang et al., 2007) such as metallic ions $\mathrm{Cd}(\mathrm{II})$ and $\mathrm{Hg}(\mathrm{II})$ ) from aqueous media (Rivera-Utrilla et al., 2011).

AC can be used as powdered activated carbon (PAC) or as granular activated carbon (GAC). The fundamental difference between PAC and GAC is the particle size, which has an influence on the adsorption rate of AC: smaller AC particles adsorb a specific compound more rapidly than larger AC particles (Edzwald, 2011). The smaller the particle size of AC, the larger the contact surface area to adsorb (Jusoh et al., 2011). Moreover the AC adsorption capacities can increase when carbon particle diameters are decreased from a few tens of micrometres to a few micrometres (Matsui et al., 2015), likely because of increased exposure of the internal carbon structure to the target compounds (Ando et al., 2010). In the case of PAC, more than 90 wt.\% must pass a $44-\mu \mathrm{m}$ sieve ( $80 \mathrm{wt} . \%$ if the AC is wood based) (Edzwald, 2011). PAC is added directly to the water as a slurry and is mainly used to improve the water quality related to seasonal problems (e.g. taste and odor compounds, micropollutants and pesticides (Chowdhury et al., 2012)) or when a barrier is needed against organic compounds from accidental (or deliberate) spills. When a particular compound must be removed on a continuous base, GAC (typically with grain size ranging between 0.4 to 1.6 $\mathrm{mm}$ (Edzwald, 2011)) is used in fixed bed contactors (rapid media filters) where both adsorption and filtration (Edzwald, 2011) as removal mechanisms can occur.

Although extensive work exists on the use of AC for the removal of a wide variety of organic and inorganic pollutants and AC is generally considered as a simple and effective method for water treatment (Edzwald, 2011), the viability of AC treatment for the removal of eNPs is still at its very initial stage. 


\section{Chapter 6}

Valuable insights on the interaction between GAC and silica eNPs were reported in Salih et. al. (2011) although the main focus of their work was to evaluate the removal of trichloroethylene by GAC in presence of silica eNPs rather than study the removal efficiency of silica eNPs (Salih et al., 2011). Nonetheless, the authors observed an electrostatic interaction between silica eNPs (average diameter $30 \mathrm{~nm}$ and surface charge about $-40 \mathrm{mV}$ ) and GAC, which facilitated the attachment of silica eNPs onto the GAC surface. This attachment occurs on the external GAC surface via the meso-pores that are the route for eNPs to micro pore channels in the AC structure (responsible of most of the specific GAC surface area) and where target compounds are mainly removed by adsorption. As mentioned before the main focus of this study was to evaluate the influence of silica eNPs on the removal of trichloroethylene by GAC and therefore detailed removal efficiency of silica eNPs were not reported.

Electrostatic interactions play an important role also in the removal of certain eNPs from aqueous streams using AC, such as in the case of silver eNPs (average diameter $60 \mathrm{~nm}$ and surface charge about $-36 \mathrm{mV}$ ) (Gicheva and Yordanov, 2013). Silver eNPs were completely removed by adsorption deposition on AC surface and this was achieved in the presence of electrolytes $(40 \mathrm{mM} \mathrm{NaCl})$. The removal mechanism was attributed to the increasing eNPs aggregation on the AC surface by means of eNPs electrostatic destabilization as consequence of the electrolytes present in the water dispersion.

Gicheva and Yordanov, (2013) found that silver eNPs adsorption on AC could be described by Freundlich and Langmuir isotherms models, which have been previously used for the assessment of the environmental behaviour of organic chemicals and metals (Praetorius et al., 2014). Both models, Freundlich and Langmuir, interpret experimental data based on the theories of equilibrium partitioning. However this approached applied in the context of eNPs have been recently under discussion by several authors (Cornelis, 2015a; Praetorius et al., 2014).

The authors argue that application equilibrium partition coefficients of eNPs between two different phases, e.g. liquid-solid phases, lacks of scientific justification: differently from solutes, eNPs mixed in water do not form solution (uniform phase with same chemical composition on macro and microscopic level) but colloidal dispersion (multi-phase system of particles dispersed in a continuous phase of a different composition uniform only on a 
macroscopic scale) which are thermodynamically unstable by nature impending the application of equilibrium concept. As a consequence, eNPs are present in the environment as thermodynamically unstable dispersions and the equilibrium of eNPs at liquid-solid interfaces can only be kinetically controlled and not thermodynamically. This means that the equilibrium partition coefficient cannot be used as a descriptor for the adsorption of eNPs in natural and engineered aquatic environments. Other parameters must thus be considered to describe the sorption deposition (Praetorius et al., 2014) such as kinetic deposition or attachment efficiency coefficients.

Nonetheless, isotherm sorption experiments are useful to determine the influences of hydrophobic and electrostatic forces governing the deposition of $\mathrm{nC}_{60}$ in soil (Forouzangohar and Kookana, 2011) which can be still observed even if the thermodynamic equilibrium is not reached.

Although we report sorption isotherm experiments here, we are aware of these considerations and such measurements are only aimed to study the kinetic deposition of $\mathrm{nC}_{60}$ on $\mathrm{AC}$ and investigate the role of electrostatic interaction between $\mathrm{nC}_{60}$ and $\mathrm{AC}$ surface, rather than quantifying partition coefficients to model and predict the adsorption of $\mathrm{nC}_{60}$ on $\mathrm{AC}$ in water treatment.

Differently from batch adsorption isotherm, column experiments are not based on the equilibrium concept and should provide a more accurate description of attachment efficiency of eNPs to AC. They have been indicated as an appropriate method for the determination of the deposition efficiency of thermodynamically unstable colloid dispersions such as eNPs (Praetorius et al., 2014) and therefore are also reported in this study.

The aim of this work is to investigate the potential of $\mathrm{AC}$ treatment in removing $\mathrm{nC}_{60}$ from aqueous dispersions. Since negatively charged eNPs are likely to pass through treatment processes such as sedimentation or granular filtration (Troester et al., 2016), the use of AC as adsorbent in different stages of the water treatment process is a viable option to remove eNPs by electrostatic adsorption.

Investigation of $\mathrm{nC}_{60}$ deposition on $\mathrm{AC}$ was performed with ultrapure water and by using real surface water to analyse the impact of AC in the removal of eNPs. The work touches upon the role of AC grain size and electrostatic interactions. Additional continuous adsorption 
experiments in a fixed-bed column were conducted to better represent practical application of AC water treatment as indicated in literature. The results of this study will facilitate water utilities to better understand the role of $\mathrm{nC}_{60}$ in drinking water treatment plants and explores if $\mathrm{AC}$, either in powdered or granular form, can be a technological solution for the removal of $\mathrm{nC}_{60}$.

\subsection{Material and Methods}

\subsubsection{Preparation of aqueous fullerene dispersions}

Fullerene- $\mathrm{C}_{60}$ (purity >99.5\%) was obtained from Sigma Aldrich (Steinheim, Germany). Toluene was purchased from Mallinckrodt Baker B.V. (Deventer, the Netherlands). Ultrapure water $(18.2 \mathrm{~m} \Omega \cdot \mathrm{cm})$ was obtained by purifying demineralized water in a Milli-Q system (Millipore, Bedford, MA). Stable aqueous $\mathrm{nC}_{60}$ dispersions were prepared using a solvent exchange/sonication procedure (Chen and Elimelech, 2007). Briefly, $50 \mathrm{mg}$ of $\mathrm{C}_{60}$ fullerene powder was added to $100 \mathrm{~mL}$ toluene and stirred for at least $12 \mathrm{~h}$. The solution of $\mathrm{C}_{60}$ in toluene was added to $350 \mathrm{~mL}$ ultrapure water in a $600 \mathrm{~mL}$ beaker. Toluene was evaporated in a sonication bath (Branson) at an energy intensity of $125 \mathrm{~W}$. Ultrapure water was regularly added each hour to compensate for the volume loss due to toluene evaporation and to avoid fullerene deposition. Through this process a colloidal dispersion of $\mathrm{nC}_{60}$ aggregates in water was obtained. Finally, it was filtered through a 0.45 and a $0.22 \mu \mathrm{m}$ cellulose acetate vacuum filter system (Corning Amsterdam, the Netherlands). The resulting $\mathrm{nC}_{60}$ stock dispersion was determined to have a concentration of $15-20 \mathrm{mg} / \mathrm{L}$ as described in the following section.

\subsubsection{Characterization of aqueous fullerene dispersions}

Characterization of the $\mathrm{nC}_{60}$ stock dispersion was performed with a set of different analytical techniques. The actual formation of the colloidal dispersions was proven by UV-VIS spectrophotometry. The $\mathrm{nC}_{60} \mathrm{UV} / \mathrm{VIS}$ absorption spectrum of the feed solution displayed two typical peaks at 250 and $360 \mathrm{~nm}$ (not shown here), as was observed before (Jung et al., 2013). 
Concentrations of $\mathrm{nC}_{60}$ above $1 \mathrm{mg} / \mathrm{l}$ were determined spectrophotometrically by adsorption at $\lambda=250 \mathrm{~nm}$. Concentrations of $\mathrm{nC}_{60}$ dispersions below $1 \mathrm{mg} / \mathrm{l}$ were measured after liquidliquid extraction with toluene (Kolkman et al., 2013) by using normal-phase liquid chromatography coupled to high-resolution mass spectrometry and UV spectrophotometry (LC-MS-UV).

Quantification of $\mathrm{nC}_{60}$ was performed by measuring external calibration standards prepared as follow: First, a toluene solution of individual fullerenes was prepared at $40 \mathrm{mg} / \mathrm{l}$ and shaken overnight; second, the toluene solution containing $\mathrm{C}_{60}$ was diluted for the preparation of the external calibration standard curve as fully described in Kolkman et al. (2013).

The average particle size of the $\mathrm{nC}_{60}$ dispersion in ultrapure water was determined in a previous study by dynamic light scattering $(146 \mathrm{~nm})$, nanoparticle tracking analysis $(134 \mathrm{~nm})$ and analytical ultra-centrifugation (106 nm) (Floris et al., 2016). The zeta potential of the dispersion was $-42.8 \mathrm{mV} \pm 1.3$ (Floris et al., 2016). This high value of the zeta potential was also reported in several previous studies (Brant et al., 2005; Chen and Elimelech, 2009) and indicates high stability of the dispersion due to electrostatic repulsion.

\subsubsection{Surface water characterization}

Surface water was obtained from the Lek canal (Nieuwegein, the Netherlands) prior to the Amsterdam Water Supply Dunes uptake. Prior to the adsorption experiments, the surface water was filtered subsequently through a 0.45 and a $0.22 \mu \mathrm{m}$ cellulose acetate vacuum filter system (Corning Amsterdam, the Netherlands) to remove dispersed solids. The water composition of the filtered surface water was previously determined (Chapter 3) by the laboratory of the water supply company Vitens (Leeuwarden, the Netherlands).

\subsubsection{Powdered and granular activated carbon}

A commercially available bituminous based GAC Filtrasorb 400 (F400) Chemviron Carbon (Feluy, Belgium) was used for the adsorption studies. F400 is widely used for water treatment and often considered as a reference adsorbent in studies on pollutant removal from aqueous solutions (Morlay and Joly, 2009). Prior to the adsorption experiments, the hydrophobic 


\section{Chapter 6}

(Mahmudov and Huang, 2014) GAC was sieved through subsequently $600 \mu \mathrm{m}$ and $700 \mu \mathrm{m}$ sieves to remove course material and to obtain a narrow size distribution. This fraction of grains between $600 \mu \mathrm{m}$ and $700 \mu \mathrm{m}$ was used in the experiments. The GAC grains were washed with ultrapure water (2.5 l of water for $100 \mathrm{ml}$ volume of AC) to remove the dust and then dried at $105^{\circ} \mathrm{C}$ for $24 \mathrm{~h}$.

PAC was obtained from the same starting material by crushing F400 granules using a mixer grinder. The PAC was then sieved using sieves with mesh sizes between 53-74 $\mu \mathrm{m}$ to obtain a narrow size distribution. The PAC was washed with ultrapure water ( 2.51 of water for 100 $\mathrm{ml}$ volume of $\mathrm{AC}$ ) to remove the dust and then dried at $105{ }^{\circ} \mathrm{C}$ for $24 \mathrm{~h}$. The physical characteristic of both GAC and PAC grains are summarized in Table 5-1 (Salih et al., 2012). 
Table 6-1: Physical characteristics of F400 activated carbon (from (Salih et al., 2012))

\begin{tabular}{llll}
\hline Parameter & & GAC* & PAC** \\
\hline BET surface area & $\mathrm{m}^{2} / \mathrm{g}$ & 745 & 778 \\
Micro-pore area (width $<5 \mathrm{~nm})$ & $\mathrm{m}^{2} / \mathrm{g}$ & 479 & 447 \\
Meso-pore area (width $>5 \mathrm{~nm})$ & $\mathrm{m}^{2} / \mathrm{g}$ & 265 & 332 \\
Micro-pore volume & $\mathrm{cm}^{3} / \mathrm{g}$ & 0.27 & 0.25 \\
Total pore volume & $\mathrm{cm}^{3} / \mathrm{g}$ & 0.48 & 0.47 \\
Fraction micro-porosity & $\%$ & 64 & 57 \\
pH & - & 7.6 & 7.6 \\
Charge at $\mathrm{pH} 7$ & $\mathrm{mV}$ & 0.16 & 0.16 \\
\hline
\end{tabular}

* Measured for the size fraction with diameter 0.841-1.18 mm diameter;

** Measured for the size fraction with diameter $125-150 \mu \mathrm{m}$ diameter.

The literature data from Table 6-1 show that crushing the granules (GAC) to powder (PAC) affects the AC pore size distribution by increasing the percentage of meso-pores $(2-50 \mathrm{~nm}$ pore width) due to breakdown of the macro-pores (>50 nm pore width). Meanwhile the number of micro-pores ( $<2 \mathrm{~nm}$ pore width) remains relatively similar. However, only a small change (4\%) in the BET surface area was observed. The AC was found to have a neutral surface with a negligible charge of $+0.16 \mathrm{mV}$ (Salih et al., 2012) around $\mathrm{pH} 8$ (pH of the surface water used in this study), which indicates negligible electrostatic interactions between F400 and $\mathrm{nC}_{60}$. Conversely the charge of the AC surface increases to $+20 \mathrm{mV}$ (Salih et al., 2011 ) in the $\mathrm{pH}$ range of ultrapure water ( $\mathrm{pH} 5.5$ ) promoting $\mathrm{nC}_{60}$ adsorption by electrostatic attraction.

\subsubsection{Attachment efficiency}

To determine the attachment efficiency of $\mathrm{nC}_{60}$ to $\mathrm{AC}$, sorption experiments were performed using two slightly different procedures as described in the following subsections. 


\section{Chapter 6}

\subsubsection{PAC adsorption}

Six 0.51 glass reagent bottles were filled with the $\mathrm{nC}_{60}$ water dispersion with a concentration of $5 \mathrm{mg} / \mathrm{l}$ and increasing PAC concentrations ranging from 0 to $500 \mathrm{mg} / \mathrm{l}(0,10,20,100,200$ and $500 \mathrm{mg} / \mathrm{l}$ ) were added to the subsequent bottles. Glass bottles were placed onto a multiposition magnetic stirrer set at a rotation speed of $250 \mathrm{rpm}$ inside an incubator (HettCube 400R) at $20{ }^{\circ} \mathrm{C}$. At the end of the contact period of 48 hours $^{2}$ samples from each bottle were taken for concentration analysis.

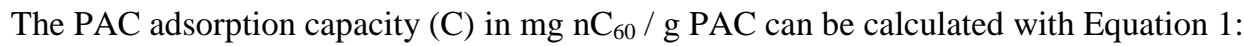

$\mathrm{C}=\frac{\mathrm{C}_{0}-\mathrm{C}_{\mathrm{ft}}}{\mathrm{m}}$

With $\mathrm{C}_{0}$ and $\mathrm{C}_{\mathrm{f}}$ the $\mathrm{nC}_{60}$ concentration at the beginning and at the end of the experiment $(\mathrm{mg} / \mathrm{l})$, respectively, and $\mathrm{m}$ the mass of PAC $(\mathrm{g})$.

\subsubsection{GAC adsorption}

Two $\mathrm{nC}_{60}$ dispersions of 121 each were prepared by diluting a $\mathrm{nC}_{60}$ stock dispersion (15-20 $\mathrm{mg} / \mathrm{l}$ ) to the concentration of $0.4 \mathrm{mg} / \mathrm{l}$ in (i) ultrapure water and in (ii) $0.2 \mu \mathrm{m}$ pre-filtered surface water. The diluted $\mathrm{nC}_{60}$ dispersions $(0.4 \mathrm{mg} / \mathrm{l})$ were then used to fill 2 set of 5 bottles (1 1 volume) containing different amounts of dried $\operatorname{GAC}(0,10,20,40,80$ and $160 \mathrm{mg})$. The resulting 2 sets of bottles ( 1 set with $0.4 \mathrm{mg} / \mathrm{nC}_{60}$ in ultrapure water and 1 set with $0.4 \mathrm{mg} / \mathrm{l}$ $\mathrm{nC}_{60}$ in surface water) were placed on multi-position magnetic stirrers inside an incubator (HettCube 400R) at $20{ }^{\circ} \mathrm{C}$ for 6 weeks at a rotation speed of $300 \mathrm{rpm}$. Samples for concentration analysis were taken from the bottles after 1, 2, 3 and 6 weeks. Experiments were performed in duplicate. Because GAC adsorption takes longer than for PAC, often more than a week longer (Zhao et al., 2011), even though 6 weeks are a much longer contact time than conventionally used in water treatment plants operations.

\footnotetext{
${ }^{2}$ Based on previous study with silver eNPs and AC (Gicheva and Yordanov, 2013)
} 


\subsubsection{Column study}

Continuous adsorption experiments in a fixed-bed AC column were conducted to better represent the practical application of AC in water treatment. Different from batch adsorption experiments, a fresh eNP dispersion continuously enters and exists the column, therefore complete equilibrium is not established at any stage between the adsorbate and the adsorbent (Goel et al., 2005). A chromatography glass column (height $80 \mathrm{~cm}$ and an internal diameter of $1.8 \mathrm{~cm}$, including a porous glass support) was filled with GAC (same material used in the GAC sorption experiments, see section 2.4). Before the experiment, the column was flushed overnight with ultrapure water to equilibrate the column by removing entrapped air. A dispersion of $\mathrm{nC}_{60}$ in ultrapure water at the concentration of $5 \mathrm{mg} / \mathrm{l}$ was fed to the column downwards by gravity at a rate of $1.6 \mathrm{l} / \mathrm{h}$, resulting in a contact time between $\mathrm{nC}_{60}$ and GAC of 20 minutes. Column effluent samples were collected at definite intervals of filtered volume, specifically each $100 \mathrm{ml}$ of volume filtered. Sampling of the outlet was carried out during the complete filtration run, and was complemented by two additional samples during a final flushing with ultrapure water. The water samples were analysed on their $\mathrm{nC}_{60}$ fraction in the column effluent. The fraction was determined spectrophotometrically by UV adsorption (A) at $\lambda=250 \mathrm{~nm}$ and compared with the $\mathrm{UV}$ adsorption of the feed $\mathrm{nC}_{60}$ dispersion $\left(\mathrm{A}_{0}\right)$. The evolution of the relative absorption at this specific wavelength was plotted against the ratio Permeate Volume/Pore Volume $\left(\mathrm{V} / \mathrm{V}_{0}\right)$, which indicates the progression of the column experiment. 


\subsection{Results and discussion}

\subsubsection{Removal efficiency of PAC in ultrapure water in batch tests}

The $\mathrm{nC}_{60}$ removal by PAC in batch tests after 48 hours contact time (based on Gicheva and Yordanov (2013) is shown in Figure 6-1.

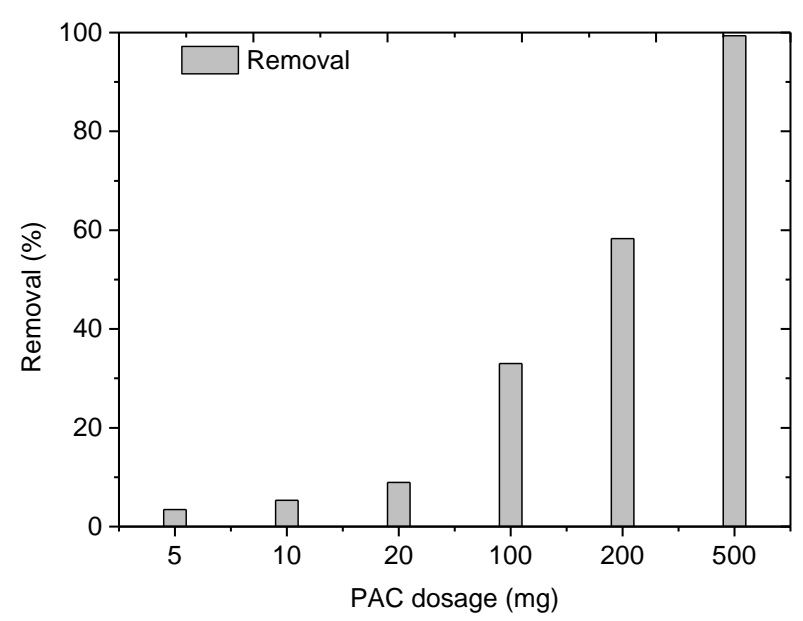

Figure 6-1: Removal of $n C_{60}$ in ultrapure water with different PAC dosages after a contact time of 48 hours

The removal of $\mathrm{nC}_{60}$ increases with the PAC dosage. Almost a complete removal (99.3\%) was obtained at a dosage of $500 \mathrm{~g}$ PAC suggesting a strong affinity between PAC and $\mathrm{nC}_{60}$. Electrostatic interactions can explain the attachment mechanism: $\mathrm{nC}_{60}$ is negatively charged $(-42.8 \mathrm{mV} \pm 1.3)$ when dispersed in ultrapure water (Floris et al., 2016), meanwhile PAC is positively charged $(+20 \mathrm{mV})$ in ultrapure water (Salih et al., 2011) therefore promoting the removal of $\mathrm{nC}_{60}$ by electrostatic attractions. 


\subsubsection{Removal efficiency of GAC in ultrapure water in batch tests}

$\mathrm{nC}_{60}$ removal by $\mathrm{GAC}$ adsorption in ultrapure water is presented in Figure 6-2.

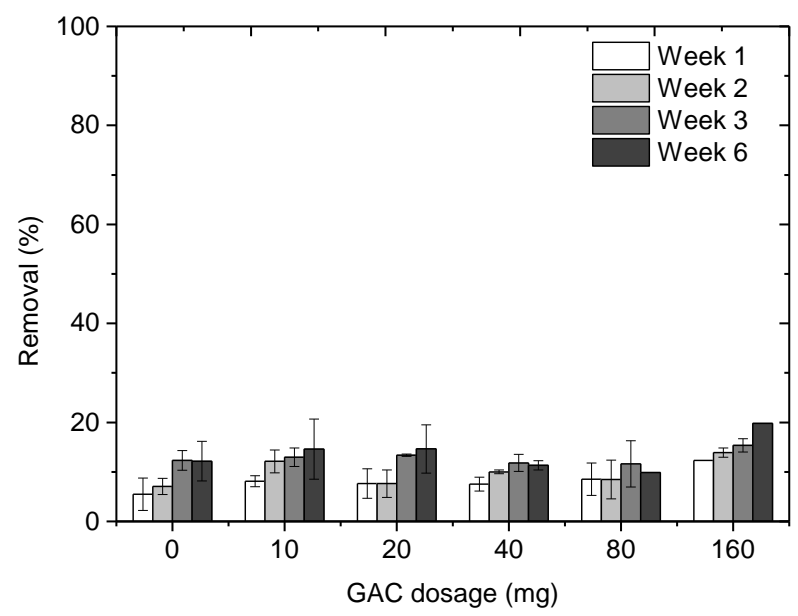

Figure 6-2: $n C_{60}(0.4 \mathrm{mg} / \mathrm{l})$ removal by adsorption in ultrapure water for the different $G A C$ dosages after 1, 2, 3 and 6 weeks.

Control experiments $\left(0 \mathrm{~g}\right.$ GAC) resulted in a low removal of $\mathrm{nC}_{60}(\sim 6 \%)$ after 2 weeks. This removal was attributed to the attachment of $\mathrm{nC}_{60}$ to the surface of the bottle and/or the surface of the stirring bar used for the experiments. Removal slightly increased in week 3 to $12 \%$ and stabilized in week 6 . After 6 weeks of mixing $~ 90 \%$ of $\mathrm{nC}_{60}$ remained in the dispersion, which indicates that the $\mathrm{nC}_{60}$ colloidal dispersion was kinetically stable. Dosages from 10 to $80 \mathrm{~g}$ of $\mathrm{AC}$ had no significant effects (Figure 2) on the $\mathrm{nC}_{60}$ removal compared with the control experiments. Dosage of $160 \mathrm{~g}$ of GAC increased the removal up to $20 \%$ after 6 weeks. As described by the Derjaguin-Landau-Verwey-Overbeek (DLVO) theory of colloidal stability (Praetorius et al., 2014), eNP adsorption to the surface is controlled by the electrical double-layer, van-der-Waals interactions, and hydration and hydrophobic forces. Their sum results in a total interaction energy that is a function of the particle-surface distance. At conditions in which the total interaction energy of the colloidal system results in repulsive forces, eNP deposition requires sufficient kinetic energy to overcome these repulsive forces. 


\section{Chapter 6}

Despite the mixing conditions in the GAC and PAC adsorption experiments were similar, removal values obtained with PAC are much higher than the corresponding values obtained with GAC. We speculate that differences in removal values between PAC and GAC can be related to the higher external specific surface of PAC compared to GAC as it was already reported (Ando et al., 2010) that the adsorption capacity of AC for hydrophobic macromolecules such as NOM increases as the median particle diameter of AC decreases. The same study reported that the change in carbon particle size due to grinding did not result in any substantial change in internal pore size distribution, and therefore the dependency of the NOM adsorption capacity was not related to the internal pore structure. A similar observation was also obtained by Hu et al. (2015) and Salih et al. (2012) confirming that the structural features of the carbon internal pores are unlikely to be altered by grinding. The hydrodynamic size of the hydrophobic $\mathrm{nC}_{60}$ used in this experiment was measured as $146 \mathrm{~nm}$ (Floris et al., 2016), which makes it improbable that adsorption in the internal pore structure (micro and meso pores) of the AC occurred. Therefore it is reasonable to attribute the lower removal of GAC (compared to PAC) to the change in the AC particle size and consequently to the change of the specific external surface area (Ando et al., 2010) and external adsorption capacity of the AC (Weber et al., 1983). 


\subsubsection{Removal efficiency of GAC in surface water}

The adsorption of $\mathrm{nC}_{60}$ dispersed in surface water using $\mathrm{GAC}$ is presented in Figure 6-3.

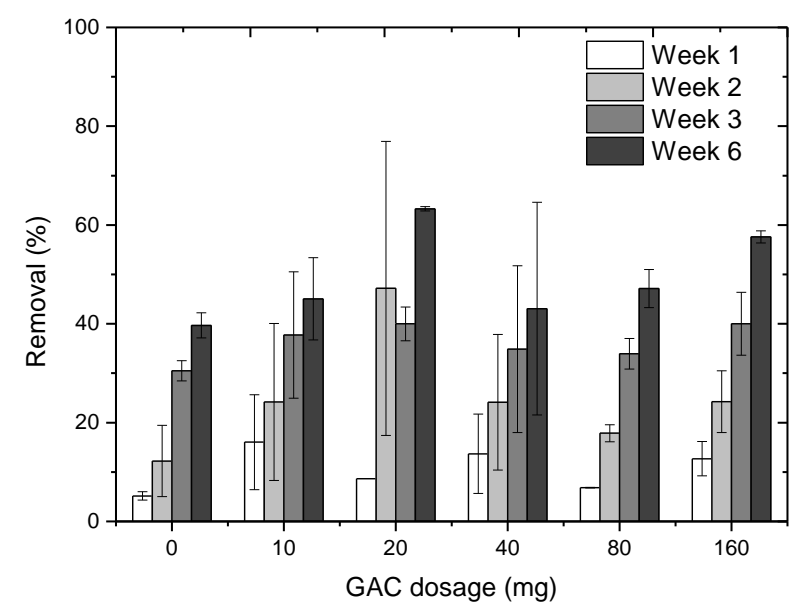

Figure 6-3: The adsorption of $n C_{60}$ dispersed in surface water $(0.4 \mathrm{mg} / \mathrm{l})$ for different $G A C$ dosages after 1, 2, 3 and 6 weeks.

Removal of $\mathrm{nC}_{60}$ dispersed in surface water reached significantly higher values $(>40 \%$ for all dosages after 6 weeks) compared to the ultrapure water experiments. However also in surface water the dosage of GAC has little effect on the removal when compared with the control experiment ( $0 \mathrm{~g}$ GAC dosage).

It must be also noticed that the removal of the control experiment in surface water after 6 weeks reaches value of about $40 \%$ and the addition of $160 \mathrm{~g}$ of GAC increases the $\mathrm{nC}_{60}$ removal up to $60 \%$ always after 6 weeks of continuous mixing. Therefore, the contribution of $\mathrm{nC}_{60}$ adsorption to $\mathrm{GAC}$ seems no to contribute predominantly to the total removal of $\mathrm{nC}_{60}$ in surface water. Comparing the control experiments in ultrapure water (Figure 6-2) and surface water (Figure 6-3), it is clear that the water matrix composition does have an effect on the long term stability of the $\mathrm{nC}_{60}$ dispersion: only $\sim 12 \%$ of $\mathrm{nC}_{60}$ is removed after 6 weeks of continuous mixing when ultrapure water is used, contrary to $\sim 40 \%$ for the dispersion in surface water. The negative surface charge of $\mathrm{nC}_{60}$ is the main factor that provides stability to $\mathrm{nC}_{60}$ in dispersion. If the zeta-potential of the $\mathrm{nC}_{60}$ dispersion is reduced, the repulsive 


\section{Chapter 6}

forces between the $\mathrm{nC}_{60}$ are reduced and particles tend to agglomerate and sediment (Chen and Elimelech, 2009). Earlier research showed that the water matrix of the dispersion strongly influences the zeta potential of the $\mathrm{nC}_{60}$ particles. The surface charge of $\mathrm{nC}_{60}$ dispersed in ultrapure water is approximately $-40 \mathrm{mV}$ while $\mathrm{nC}_{60}$ dispersed in surface water have a zeta potential of only $-15 \mathrm{mV}$ (Chapters 2 and 3 of this thesis). The reduction of the $\mathrm{nC}_{60}$ zeta potential and consequentially of the repulsive forces between $\mathrm{nC}_{60}$ resulting in eNPs agglomeration and sedimentation.

Unstable particles that continuously settle out of the dispersion can also blind out a potential kinetical equilibrium of $\mathrm{nC}_{60}$ on $\mathrm{AC}$. This can also explain why a steady state is not reached within the 6 weeks of the experiment duration. Moreover at the surface water $\mathrm{pH} 8$ the AC surface charge is almost neutral (+0.16 mV (Salih et al., 2012)) decreasing substantially electrostatic interactions between the $\mathrm{AC}$ and the negatively charged $\mathrm{nC}_{60}$ and decreasing the attachment possibilities. Therefore, we attributed the observed removal of $\mathrm{nC}_{60}$ to its decreased stability due to the surface water composition. We conclude that the stability of $\mathrm{nC}_{60}$ colloidal dispersion predominantly control the removal rather than the deposition on GAC, similarly to the sorption of $\mathrm{nC}_{60}$ on natural soils (Forouzangohar and Kookana, 2011). 


\subsubsection{Removal efficiency of GAC (column experiment)}

The breakthrough curve of $\mathrm{nC}_{60}$ obtained for a GAC fixed-bed column experiment is reported in Fig 4. The evolution of the relative absorption at $250 \mathrm{~nm}$ wavelength is plotted against the progression of the column experiment indicated by the ratio $\mathrm{V} / \mathrm{V}_{0}$.

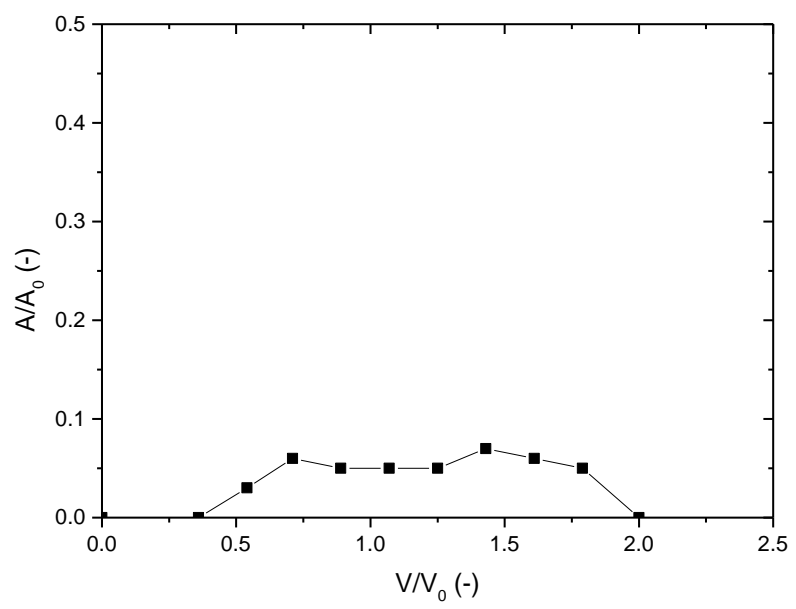

Figure 6-4: Breakthrough curve of $n C_{60}$ (initial concentration of $5 \mathrm{mg} / \mathrm{l}$ ) obtained by $G A C$ fixed-bed column.

A complete breakthrough of $\mathrm{nC}_{60}$ will be obtained when the relative adsorption $\left(\mathrm{A} / \mathrm{A}_{0}\right)$ reaches the value 1 , in other words when the adsorption of the effluent is equal to the adsorption of the influent. In our experiments a partial breakthrough appeared before that the column was completely filled with the $\mathrm{nC}_{60}$ dispersion (i.e. at $\mathrm{V} / \mathrm{V}_{0}=1$ ) and this can be led by smaller pore volume in the column due to entrapped water in the micro and meso-pore structure of the AC. After the occurrence of the breakthrough the relative adsorption $\left(\mathrm{A} / \mathrm{A}_{0}\right)$ slightly increased up to 0.07 at the end of the filtration of $\mathrm{nC}_{60}(\mathrm{~V} / \mathrm{Vpore}=1.43)$. Overall the experiment resulted in a high removal of $\mathrm{nC}_{60}(\sim 99 \%)$ compared to the isotherm experiment in ultrapure water $(\max 20 \%)$ and the difference might be explained by different kinetic conditions of the 2 experiments (Cornelis, 2015b) as discussed in the following section. 


\subsubsection{Overall removal efficiency of $\mathrm{nC}_{60}$ by $\mathrm{AC}$}

Comparison of the removal of $\mathrm{nC}_{60}$ by the 2 different forms of $\mathrm{AC}$ shows that removal values obtained with PAC are much higher than the corresponding values obtained with GAC, even though the higher amount of GAC dosage per unit of $\mathrm{nC}_{60}$ in dispersion with respect to the PAC dosage. This is evident in Figure 6-5 where are reported 3 experimental removal data versus comparable $\mathrm{AC}$ dosage per unit of $\mathrm{nC}_{60}$ for PAC and $\mathrm{GAC}$.

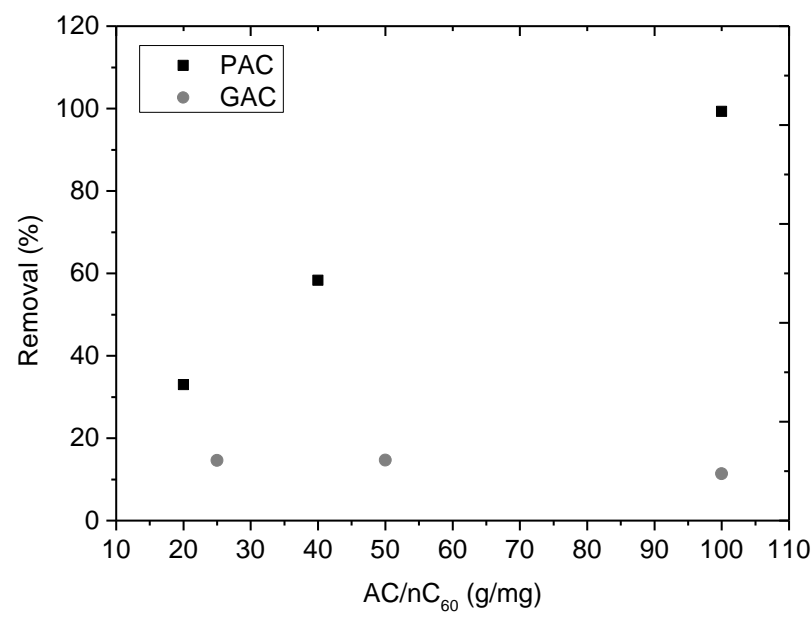

Figure 6-5: Removal of $n C_{60}$ in ultrapure water with PAC (after 48 hours contact time) and GAC (after 6 weeks contact time) with comparable dosages of $A C$ per unit of $n C_{60}$.

Reducing the AC particle size results in an increase of the external specific surface area (Ando et al., 2010) and therefore in an increase of the external surface attachment capacity of the AC (Weber et al., 1983). Similarly, the granulated form of activated carbon was found to limit the diffusion of silver eNPs to the surface inside the granules (Gicheva and Yordanov, 2013). The attachment of silica eNPs on the GAC external surface caused pore-blocking in the GAC (Salih et al., 2011) limiting the access to the internal structure of the GAC and in fact reducing the specific surface area available for adsorption. This can also partially explain the differences in the removal of $\mathrm{nC}_{60}$ by PAC and GAC. However, data shown in Table 6-1 confirm that the change in AC particle size after crushing did not result in any substantial change in internal pore size distribution of the $\mathrm{AC}$, and therefore the dependency of the $\mathrm{nC}_{60}$ 
removal must be related to the increasing external specific surface of the carbon due to the AC particle decrease. Nonetheless these results indicates that the electrostatic interactions between $\mathrm{nC}_{60}$ can play an important role on the adsorption: changing the water $\mathrm{pH}$ from 5.5 to 8 ( $\mathrm{pH}$ conditions in our experimental set-up) reduces the surface charge of F400 from approximately $+20 \mathrm{mV}$ to $+0.16 \mathrm{mV}$ (Salih et al., 2011), as well as the surface charge of the $\mathrm{nC}_{60}$ approximately from $-40 \mathrm{mV}$ to $-15 \mathrm{mV}$ (Chapters 2 and 3 this Thesis), resulting in a reduced electrostatic attraction between $\mathrm{AC}$ and $\mathrm{nC}_{60}$.

The same correlation between surface charge and deposition of $\mathrm{nC}_{60}$ to solid surface was found in a study of $\mathrm{nC}_{60}$ sorption on soils (Forouzangohar and Kookana, 2011). According the authors, the nature (positive or negative) and the intensity of surface charges are determining the sorption behaviour of these particles in soil. The $\mathrm{nC}_{60}$ sorption to negatively charged soil surface increased when $\mathrm{nC}_{60}$ changed from more to less negatively charged and therefore when the repulsive forces between eNPs and soil were low.

According to Praetorius et al. (2014) column tests represent the kinetic and irreversible deposition of eNPs in granular materials better obtaining more rigorous representation than isotherm experiments. However, as pointed out by Cornelis et al. (2015), environmental realism of column experiments should not be overstated: the application of the colloidal filtration theory to calculate the attachment efficiency as suggested by Praetorius et al. (2014), required a well-defined experimental system that increase the complexity of the model and the difficulties of its implementation. These considerations assume more significance when colloidal filtration theory is applied to AC columns that must be idealized as homogenous, well-defined granular media which is not straightforward because of the inherent chemical surface heterogeneities and articulated internal pore structure of AC grains.

Despite the challenges in identify the most appropriate experimental framework in assessing the kinetic deposition of eNPs in porous media, and more specifically here $\mathrm{nC}_{60}$ in $\mathrm{AC}$, the removal efficiencies of $\mathrm{nC}_{60}$ obtained by isotherm experiments indicate that $\mathrm{AC}$ treatment cannot be considered an absolute barrier to remove $\mathrm{nC}_{60}$ in water treatment plant. Conversely, the column test conducted seems to suggest that under more representative conditions (filtration of the $\mathrm{nC}_{60}$ dispersion through an $\mathrm{GAC}$ fixed-bed column) the retention of $\mathrm{nC}_{60}$ by GAC can be considerable. Nonetheless, there is still a need for experimental strategy that can compromise between the operational simplicity of isotherm experiments (Cornelis et al. 


\section{Chapter 6}

2015) and the technical accuracy of a time consuming column test (Praetorius et al. 2014) assessing the kinetic deposition of eNPs in porous media relevant for water treatment such as AC.

On the basis of these results, if $\mathrm{nC}_{60}$ is occurring in water sources seasonally or from accidental spills in the water high dosage of PAC with a positively surface charge can be a reliable alternative in removing this nanomaterial in water treatment plant. This in contrast if $\mathrm{nC}_{60}$ is occurring on continuous base GAC used in fixed bed contactors could potentially retain the $\mathrm{nC}_{60}$.

\subsection{Conclusions}

Removal of $\mathrm{nC}_{60}$ by adsorption on commercially available $\mathrm{AC}$ was investigated conducting isotherm and column experiment with PAC and GAC. The removal efficiency was found to be dependent on the AC particle size. PAC was able to remove (depending on the PAC dosage up to $100 \%$ ) the $\mathrm{nC}_{60}$ in ultrapure water within 48 hours contact time in batch tests. Removal of $\mathrm{nC}_{60}$ by $\mathrm{GAC}$ was much less efficient than PAC (of the same AC material) in ultrapure water which was attributed to the higher exposure of $\mathrm{nC}_{60}$ to the internal carbon structure of PAC after the crushing procedure. Higher removal by $\mathrm{GAC}$ was obtained with $\mathrm{nC}_{60}$ dispersion in surface water. However, the removal increase was attributed the electrostatic instability of $\mathrm{nC}_{60}$ when dispersed in surface water. Therefore, we conclude that on the basis of this research positively charged PAC can be a solution only if used with high dosage in case of seasonally or accidental spills in the water sources, while if the occurrence of $\mathrm{nC}_{60}$ in the water source is continuous GAC in fixed-bed column might be a solution.

\section{Acknowledgement}

This research was sponsored by the Joint Research Programme of KWR Watercycle Research Institute for the Dutch Drinking Water Companies and supported by NanoNextNL, a micro and nanotechnology consortium of the Government of the Netherlands and 130 partners. 


\section{References}

Ando, N., Matsui, Y., Kurotobi, R., Nakano, Y., Matsushita, T., 2010. Comparison of natural organic matter adsorption capacities of super-powdered activated carbon and powdered activated Carbon. Water Res. 44, 4127-4136. doi:10.1016/j.watres.2010.05.029

Baena, J.R., Gallego, M., Valca, M., Division, A.C., 2002. Fullerenes in the analytical sciences. Trends Anal. Chem. 21, 187-198.

Bakry, R., Vallant, R.M., Najam-ul-Haq, M., Rainer, M., Szabo, Z., Huck, C.W., Bonn, G.K., 2007. Medicinal applications of fullerenes. Int. J. Nanomedicine.

Baun, A., Sørensen, S.N., Rasmussen, R.F., Hartmann, N.B., Koch, C.B., 2008. Toxicity and bioaccumulation of xenobiotic organic compounds in the presence of aqueous suspensions of aggregates of nano-C60. Aquat. Toxicol. 86, 379-387. doi:10.1016/j.aquatox.2007.11.019

Bhatnagar, A., Hogland, W., Marques, M., Sillanpää, M., 2013. An overview of the modification methods of activated carbon for its water treatment applications. Chem. Eng. J. 219, 499-511.

Brabec, C.J., Sariciftci, N.S., Hummelen, J.C., 2001. Plastic Solar Cells. Adv. Funct. Mater. 11, 15-26. doi:10.1002/1616-3028(200102)11:1<15::AID-ADFM15>3.0.CO;2-A

Brant, J., Lecoanet, H., Hotze, M., Wiesner, M., 2005. Comparison of electrokinetic properties of colloidal fullerenes (nC60) formed using two procedures. Environ. Sci. Technol. 39, 6343-51.

Chae, S.-R., Wang, S., Hendren, Z., Wiesner, M., Watanabe, Y., Gunsch, C., 2009. Effects of fullerene nanoparticles on Escherichia coli K12 respiratory activity in aqueous suspension and potential use for membrane biofouling control. J. Memb. Sci. 329, 68-74. doi:10.1016/j.memsci.2008.12.023

Chen, K.L., Elimelech, M., 2009. Relating colloidal stability of fullerene (C60) nanoparticles to nanoparticle charge and electrokinetic properties. Environ. Sci. Technol. 43, 7270-6.

Chen, K.L., Elimelech, M., 2007. Influence of humic acid on the aggregation kinetics of fullerene (C60) nanoparticles in monovalent and divalent electrolyte solutions. J. Colloid Interface Sci. 309, 126-134.

Chowdhury, Z.K., Westerhoff, G.P., Summers, R.S., Leto, B., Nowack, K., 2012. Activated Carbon: Solutions for Improving Water Quality. American Water Works Association.

Cornelis, G., 2015a. Fate descriptors for engineered nanoparticles: the good, the bad, and the ugly. Environ. Sci. Nano 2, 19-26. doi:10.1039/C4EN00122B

Cornelis, G., 2015b. Fate descriptors for engineered nanoparticles: The good, the bad, and the ugly. Environ. Sci. Nano 2, 19-26. doi:10.1039/c4en00122b

Deguchi, S., Alargova, R.G., Tsujii, K., 2001. Stable Dispersions of Fullerenes , C 60 and C 70 , in Water . Preparation and Characterization. Langmuir 17, 6013-6017. 
Edzwald, J.K., 2011. Water Quality and Treatment: A Handbook on Drinking Water, Sixth. ed. American Water Works Association, American Society of Civil Engineers, McGraw-Hill.

Farré, M., Pérez, S., Gajda-schrantz, K., Osorio, V., Kantiani, L., Ginebreda, A., Barceló, D., 2010. First determination of C60 and C70 fullerenes and N-methylfulleropyrrolidine C60 on the suspended material of wastewater effluents by liquid chromatography hybrid quadrupole linear ion trap tandem mass spectrometry. J. Hydrol. 383, 44-51. doi:10.1016/j.jhydrol.2009.08.016

Floris, R., Nijmeijer, K., Cornelissen, E.R., 2016. Removal of aqueous nC60 fullerene from water by low pressure membrane filtration. Water Res. 91, 115-125. doi:10.1016/j.watres.2015.10.014

Forouzangohar, M., Kookana, R.S., 2011. Sorption of nano-C60 clusters in soil: hydrophilic or hydrophobic interactions? J. Environ. Monit. 13, 1190-1194.

Gicheva, G., Yordanov, G., 2013. Removal of citrate-coated silver nanoparticles from aqueous dispersions by using activated carbon. Colloids Surfaces A Physicochem. Eng. Asp. 431, 51-59. doi:10.1016/j.colsurfa.2013.04.039

Goel, J., Kadirvelu, K., Rajagopal, C., Kumar Garg, V., 2005. Removal of lead(II) by adsorption using treated granular activated carbon: Batch and column studies. J. Hazard. Mater. 125, 211-220. doi:10.1016/j.jhazmat.2005.05.032

Henry, C., Brant, J. a., 2012. Mechanistic analysis of microfiltration membrane fouling by buckminsterfullerene (C60) nanoparticles. J. Memb. Sci. 415-416, 546-557. doi:10.1016/j.memsci.2012.05.042

Henry, C., Dorr, B., Brant, J. a., 2012. Buckminsterfullerene (C60) nanoparticle fouling of microfiltration membranes operated in a cross-flow configuration. Sep. Purif. Technol. 100, 30-43. doi:10.1016/j.seppur.2012.08.019

Hofmann, T., von der Kammer, F., 2009. Estimating the relevance of engineered carbonaceous nanoparticle facilitated transport of hydrophobic organic contaminants in porous media. Environ. Pollut. 157, 1117-26. doi:10.1016/j.envpol.2008.10.022

Hu, J., Shang, R., Heijman, B., Rietveld, L., 2015. Reuse of spent granular activated carbon for organic micro-pollutant removal from treated wastewater. J. Environ. Manage. 160, 98104. doi:10.1016/j.jenvman.2015.06.011

Hyung, H., Kim, J.-H., 2009. Dispersion of C(60) in natural water and removal by conventional drinking water treatment processes. Water Res. 43, 2463-70. doi:10.1016/j.watres.2009.03.011

Jensen, A.W., Wilson, S.R., Schuster, D.I., 1996. Biological Applications of Fullerenes. Bioorg. Med. Chem. 4, 767-779.

Jung, Y.K., Kim, M.J., Kim, Y.-J., Kim, J.Y., 2013. Limitation of UV-Vis absorption analysis for determination of aqueous colloidal fullerene (nC60) at high ionic strength. KSCE J. Civ. Eng. 17, 51-59. doi:10.1007/s12205-013-1738-2

Jusoh, A., Hartini, W.J.H., Ali, N., Endut, A., 2011. Study on the removal of pesticide in agricultural run off by granular activated carbon. Bioresour. Technol. 182, 347-353. doi:10.1016/j.desal.2005.03.022 
Kolkman, A., Emke, E., Bäuerlein, P.S., Carboni, A., Tran, D.T., ter Laak, T.L., van Wezel, A.P., de Voogt, P., 2013. Analysis of (functionalized) fullerenes in water samples by liquid chromatography coupled to high-resolution mass spectrometry. Anal. Chem. 85, 5867-74. doi:10.1021/ac400619g

Kroto, H.W., Heath, J.R., O’Brien, S.C., Curl, R.F., Smalley, R.E., 1985. C60: Buckminsterfullerene. Nature 318, 162.

Lyon, D.Y., Adams, L.K., Falkner, J.C., Alvarezt, P.J.J., 2006. Antibacterial activity of fullerene water suspensions: effects of preparation method and particle size. Environ. Sci. Technol. 40, 4360-6.

Mahmudov, R., Huang, C.P., 2014. Functionalized activated carbon for the adsorptive removal of perchlorate from water solutions. Front. Chem. Sci. Eng. 9, 194-208. doi:10.1007/s11705-015-1517-3

Matsui, Y., Nakao, S., Sakamoto, A., Taniguchi, T., Pan, L., Matsushita, T., Shirasaki, N., 2015. Adsorption capacities of activated carbons for geosmin and 2-methylisoborneol vary with activated carbon particle size: Effects of adsorbent and adsorbate characteristics. Water Res. 85, 95-102. doi:10.1016/j.watres.2015.08.017

McKay, G., Bino, M.J., Altamemi, A.R., 1985. The adsorption of various pollutants from aqueous solutions on to activated carbon. Water Res. 19, 491-495. doi:10.1016/00431354(85)90041-7

Morlay, C., Joly, J.-P., 2009. Contribution to the textural characterisation of Filtrasorb 400 and other commercial activated carbons commonly used for water treatment. J. Porous Mater. 17, 535-543. doi:10.1007/s10934-009-9322-3

Musee, N., 2011. Nanowastes and the environment: Potential new waste management paradigm. Environ. Int. 37, 112-28. doi:10.1016/j.envint.2010.08.005

Navarro, E., Baun, A., Behra, R., Hartmann, N.B., Filser, J., Miao, A.-J., Quigg, A., Santschi, P.H., Sigg, L., 2008. Environmental behavior and ecotoxicity of engineered nanoparticles to algae, plants, and fungi. Ecotoxicology 17, 372-86. doi:10.1007/s10646-008-0214-0

Osawa, E., 2002. Perspective of Fullerene Nanotechnology. Berlin, Germany.

Praetorius, A., Tufenkji, N., Goss, K.U., Scheringer, M., Von Der Kammer, F., Elimelech, M., 2014. The road to nowhere: Equilibrium partition coefficients for nanoparticles. doi:10.1039/c4en00043a

Reisch, M.S., 2009. Innovation: Novel ingredients spread across incosmetics. Chem. Eng. News.

Rivera-Utrilla, J., Sánchez-Polo, M., Gómez-Serrano, V., Alvarez, P.M., Alvim-Ferraz, M.C.M., Dias, J.M., 2011. Activated carbon modifications to enhance its water treatment applications. An overview. J. Hazard. Mater. 187, 1-23. doi:10.1016/j.jhazmat.2011.01.033

Salih, H.H., Patterson, C.L., Sorial, G. a, Sinha, R., Krishnan, R., 2011. The fate and transport of the $\mathrm{SiO} 2$ nanoparticles in a granular activated carbon bed and their impact on the removal of VOCs. J. Hazard. Mater. 193, 95-101. doi:10.1016/j.jhazmat.2011.07.030 
Salih, H.H., Patterson, C.L., Sorial, G. a., Sinha, R., Krishnan, R., 2012. The implication of iron oxide nanoparticles on the removal of trichloroethylene by adsorption. Chem. Eng. J. 193-194, 422-428. doi:10.1016/j.cej.2012.03.040

Sayes, C.M., Gobin, A.M., Ausman, K.D., Mendez, J., West, J.L., Colvin, V.L., 2005. NanoC60 cytotoxicity is due to lipid peroxidation. Biomaterials 26, 7587-95. doi:10.1016/j.biomaterials.2005.05.027

Song, M., Yuan, S., Yin, J., Wang, X., Meng, Z., Wang, H., Jiang, G., 2012. Size-dependent toxicity of nano-C60 aggregates: more sensitive indication by apoptosis-related Bax translocation in cultured human cells. Environ. Sci. Technol. 46, 3457-64. doi:10.1021/es2039008

Stone, V., Nowack, B., Baun, A., van den Brink, N., Kammer, F. Von Der, Dusinska, M., Handy, R., Hankin, S., Hassellöv, M., Joner, E., Fernandes, T.F., 2010. Nanomaterials for environmental studies: classification, reference material issues, and strategies for physicochemical characterisation. Sci. Total Environ. 408, 1745-54. doi:10.1016/j.scitotenv.2009.10.035

Troester, M., Brauch, H., Hofmann, T., 2016. Vulnerability of drinking water supplies to engineered nanoparticles. Water Res. 96.

Wang, C., Dai, J., Shang, C., Chen, G., 2013a. Removal of aqueous fullerene nC60 from wastewater by alum-enhanced primary treatment. Sep. Purif. Technol. 116, 61-66. doi:10.1016/j.seppur.2013.05.035

Wang, C., Shang, C., Chen, G., Zhu, X., 2013b. Mechanisms of nC60 removal by the alum coagulation-flocculation-sedimentation process. J. Colloid Interface Sci. 411, 213-9. doi:10.1016/j.jcis.2013.08.023

Weber, W.J., Voice, T.C., Jodellah, A., 1983. Adsorption of humic substances: The effects of heterogeneity and system characteristics. J. / Am. Water Work. Assoc.

Xie, B., Xu, Z., Guo, W., Li, Q., 2008. Impact of natural organic matter on the physicochemical properties of aqueous C60 nanoparticles. Environ. Sci. Technol. 42, 28539.

Yang, C., Kheireddine, M., Mohd, W., Wan, A., 2007. Review of modifications of activated carbon for enhancing contaminant uptakes from aqueous solutions. Sep. Purif. Technol. 52, 403-415. doi:10.1016/j.seppur.2006.06.009

Yang, K., Zhu, L., Xing, B., 2006. Adsorption of Polycyclic Aromatic Hydrocarbons by Carbon Nanomaterials. Environ. Sci. Technol. 40, 1855-1861.

Zhang, L., Zhao, Q., Wang, S., Mashayekhi, H., Li, X., Xing, B., 2014. Influence of ions on the coagulation and removal of fullerene in aqueous phase. Sci. Total Environ. 466-467, 6048. doi:10.1016/j.scitotenv.2013.07.077

Zhao, D., Cheng, J., Vecitis, C.D., Hoffmann, M.R., 2011. Sorption of perfluorochemicals to granular activated carbon in the presence of ultrasound. J. Phys. Chem. A 115, 2250-2257. doi:10.1021/jp111784k 

7 CONClusions AND OUTLOOK 


\subsection{Conclusions}

This dissertation research describes the removal and removal mechanism of engineered nanoparticles (eNPs) in different drinking water treatment processes. More specifically it describes the removal and removal mechanisms of $\mathrm{nC}_{60}$, silver and gold as model eNPs during coagulation and flocculation, activated carbon filtration and micro- and ultrafiltration membrane processes.

Chapter 2 shows that low pressure membranes (micro- and ultrafiltration) can be viable barriers (removal > $99 \%$ ) for $\mathrm{nC}_{60}$ dispersed in de-ionized water depending on their pore size. Commercially available low pressure membranes efficiently remove $\mathrm{nC}_{60}$ under typical full-scale conditions, i.e. constant flux operation in dead-end membrane systems and including multiple backwash cycles (20 s min every $20 \mathrm{~min}$ ). Removal is dependent on the ratio of the $\mathrm{nC}_{60}$ particle size to membrane pore size: almost complete $\mathrm{nC}_{60}$ removal was obtained by membranes with an average pore size smaller $(\sim 18 \mathrm{~nm})$ and similar/larger $(\sim 200$ $\mathrm{nm}$ ) than the particle size (distribution) of the membrane, while membranes with an average pore size larger $(\sim 500 \mathrm{~nm})$ than the particle size (distribution) show very low removal of about $10 \%$.

The membrane permeability during filtration and the efficiency of the backwash cleaning procedure is strongly influenced by the ratio of $\mathrm{nC}_{60}$ size to membrane pore size: $96 \%$ of the initial permeability is recovered after the $5^{\text {th }}$ filtration and backwash cycle for the $18 \mathrm{~nm}$ pore size membrane while $81 \%$ of the initial permeability is recovered for the membrane with a pore size of $200 \mathrm{~nm}$.

The ratio $\mathrm{nC}_{60}$ size to membrane pore size plays an important role in the removal mechanism: steric exclusion is the main removal mechanism of $\mathrm{nC}_{60}$ for membranes with an average pore size smaller than the size of $\mathrm{nC}_{60}$, while a combination of intermediate pore blocking and cake formation on top of the membrane surface is the main removal mechanism of $\mathrm{nC}_{60}$ for membranes with an average pore size comparable to the $\mathrm{nC}_{60}$ size. The efficiency of the hydraulic backwash procedure recovering the initial membrane filtration conditions is dependent on the ratio of the cake-layer deposition resistance to the clean membrane resistance. The permeability of membranes with an average pore size smaller than $\mathrm{nC}_{60}$ is in 


\section{Chapter 7}

majority recovered by the backwash procedure, but the deposition layer on top of the membrane is hardly removed. This is attributed to the hydraulic resistance of the membrane, which is one order of magnitude higher than the resistance of the deposition layer.

Chapter 3 investigates the effect of the presence of NOM and bivalent cations on the removal of $\mathrm{nC}_{60}$ from surface water. It confirms that water treatment plants that include low pressure membrane processes, specifically microfiltration (MF), are solid barriers to remove $\mathrm{nC}_{60}$ when dispersed in natural surface water with different NOM compositions (ranging from 0.7 - $3.2 \mathrm{mg} / \mathrm{l} \mathrm{DOC})$ and concentrations of $\mathrm{Ca}^{2+}(11-75 \mathrm{mg} / \mathrm{L})$ and $\mathrm{Mg}^{2+}(<0.1-<0.5 \mathrm{mg} / \mathrm{l})$ cations.

The removal efficiency (> 99.99\%) is found to be independent on the water surface composition, however a synergistic effect on membrane fouling between $\mathrm{nC}_{60}$ and surface water constituents such as NOM and its fractions is observed. The synergistic effect manifests itself as a considerably higher TMP increase than the simple sum of surface water and $\mathrm{nC}_{60}$ TMP increase alone. From zeta-potential measurements of the eNPs, the presence of cations induces significant differences in the dispersion stability changing the zeta potential from values > |-30| $\mathrm{mV}$ (stable dispersion in absence of $\mathrm{Ca}^{2+}$ and $\mathrm{Mg}^{2+}$ ) to values $<|-17| \mathrm{mV}$ (incipient instability in the presence of $\mathrm{Ca}^{2+}$ and $\mathrm{Mg}^{2+}$ ). Although $\mathrm{Ca}^{2+}$ and $\mathrm{Mg}^{2+}$ are dominant in controlling the stability of $\mathrm{nC}_{60}$ (size and zeta potential), the extent of fouling is dominated by the presence of NOM. The total fouling can be decreased by $\sim 80 \%$ removing the negatively charged fraction of NOM, i.e. humic acids and small organic acids ( $\sim 75 \%$ removal of $\mathrm{DOC}$ ) from the surface water dispersion with $\mathrm{nC}_{60}$. In addition, the negatively charged NOM fractions lead to the formation of a compressible fouling cake layer. Removing this fraction from the feed water resulted in the formation of an incompressible cake layer and in a reduction of one order of magnitude of the transmembrane pressure (TMP) increase during filtration, represented mostly by reversible fouling. When the negatively charged fraction of NOM ( $75 \%$ removal of DOC) are removed, the presence of the divalent cations $\mathrm{Ca}^{2+}$ and $\mathrm{Mg}^{2+}$ enhances the formation of irreversible fouling ( $\sim 57 \%$ lower in absence of $\mathrm{Ca}^{2+}$ and $\mathrm{Mg}^{2+}$ ), reducing the efficiency of backwash and final flushing procedures in restoring the initial TMP. 
In Chapter 4 the potential of MF membrane as a viable barrier removing eNPs at pilot-scale is validated. MF membranes are suitable for the removal of silver and gold eNPs under typical full-scale conditions, with a constant filtration flux of $601 / \mathrm{m}^{2} \cdot \mathrm{h}$,. a backwash flow rate of 240 $1 / \mathrm{m}^{2} / \mathrm{h}$ and a backwash frequency of once every 60 minutes. Removal efficiency of eNPs by MF with an average pore size larger than the particle size distribution is $>95.7 \%$ for silver and $>99.3 \%$ for gold eNPs during the 46 filtration cycles.

The pilot investigation shows high removal efficiencies for silver and gold eNPs, something that was also found for the $\mathrm{nC}_{60}$ removal efficiency obtained at lab scale (Chapters 2 and 3 ). Visual observation during membrane autopsy seems to suggest that silver and gold eNPs are rejected by MF on the membrane surface therefore by a combination of size exclusion and pore blockage.

The transmembrane pressure profile during microfiltration of silver and gold eNPs appeared reasonably flat (both on pilot and lab scale) different from what was observed for $\mathrm{nC}_{60}$ microfiltration on lab scale. Differences between $\mathrm{nC}_{60}$, silver and gold eNP transmembrane pressure profiles can be the result of (i) different filtration resistances of the cake layer formed on top of the membrane resistance due to the different nature of the eNPs or (ii) the formation of a cake layer only without the occurrence of pore blocking on the membrane surface for silver and gold eNPs. More research is needed to clarify how separation of silver and gold eNPs from water using microfiltration occurs and to clarify these specific observations.

Chapter 5 reports the removal and removal mechanism of $\mathrm{nC}_{60}$ in coagulation-flocculationsedimentation processes (CFS) using ferric chloride as coagulant.

$\mathrm{CFS}$ is a less robust process to remove $\mathrm{nC}_{60}$, with removal efficiencies ranging from $100 \%$ down to $0 \%$, controlled by the operational $\mathrm{pH}$ and water background composition (NOM fractions and $\mathrm{Ca}^{2+}$ and $\mathrm{Mg}^{2+}$ presence).

In buffered ultrapure water, the removal efficiency of $\mathrm{nC}_{60}$ reaches a maximum removal of $85 \%$ at low $\mathrm{pH}(<6)$ which is attributed to charge neutralization and destabilization by the high concentration of cationic hydrolysis products of $\mathrm{Fe}^{3+}$ at acidic conditions. Removal drastically decreases to $34 \%$ at basic conditions ( $\mathrm{pH}=9$ and $15 \mathrm{mg} / \mathrm{l} \mathrm{FeCl}_{3}$ ) as the concentration of cationic hydrolysis products of $\mathrm{Fe}^{3+}$ decreases as well. 


\section{Chapter 7}

The removal of $\mathrm{nC}_{60}$ from pre-filtered surface water is in general higher than the removal in buffered ultra-pure water, being $\sim 100 \%$ (pre-filtered surface water) at acidic conditions and does not depend on coagulant dosage. However, it is well correlated with the removal of natural organic matter (NOM), which suggests the occurrence of co-precipitation between $\mathrm{NOM}$ and $\mathrm{nC}_{60}$. Co-precipitation becomes less important when the $\mathrm{pH}$ is increased from 6 to 8. NOM removal decreases from $70 \%$ to $20 \%$ while $\mathrm{nC}_{60}$ removal shows similar trend decreasing from $100 \%$ to $60 \%$ with this change in $\mathrm{pH}$. The presence of $\mathrm{Ca}^{2+}$ and $\mathrm{Mg}^{2+}$ seems to contribute to the removal at acidic conditions by charge neutralization and destabilization increasing the removal efficiency to $80 \%$ and $100 \%$ for dosages of 5 and $15 \mathrm{mg} / \mathrm{l}$ respectively. At a $\mathrm{pH}$ between 6 and 9 the presence of NOM in the water due to the low NOM removal, dominates the removal efficiency, stabilizing $\mathrm{nC}_{60}$ and hindering its removal. Removing the negatively charged part of the $\mathrm{NOM}$ content results in high $\mathrm{nC}_{60}$ removal $(>90 \%)$ at all dosages and $\mathrm{pH}$ values investigated. The presence of divalent cations increases the removal of $\mathrm{nC}_{60}$ to $90 \%$ at $\mathrm{pH} 9$ overcoming the NOM stabilization effects.

Chapter 6 focuses on the removal effectiveness of $\mathrm{nC}_{60}$ using activated carbon (AC). It shows that the adsorption efficiency is dependent on the AC particle size: PAC (powdered activated carbon) is able to remove (depending on the PAC dosage) up to $100 \% \mathrm{nC}_{60}$ in ultrapure water ( 48 hours contact time). Removal of $\mathrm{nC}_{60}$ by $\mathrm{GAC}$ (granulated activated carbon) is much less efficient ( $20 \%$ after 6 weeks contact time for a GAC dosage of $160 \mathrm{~g}$ ) in ultrapure water because of the lower specific surface area of GAC compared to PAC.

Higher removal by GAC was obtained with eNP dispersions in surface water containing 2.9 $\mathrm{mg} / \mathrm{l} \mathrm{DOC}$ and about 75 and $11 \mathrm{mg} / \mathrm{l}$ of $\mathrm{Ca}^{2+}$ and $\mathrm{Mg}^{2+}$. However, the removal increase of $\sim 60 \%$ was attributed to the instability of $\mathrm{nC}_{60}$ in the presence of surface water constituents, such as multivalent cations (about 75 and $11 \mathrm{mg} / \mathrm{l} \mathrm{of} \mathrm{Ca}^{2+}$ and $\mathrm{Mg}^{2+}$ ). Additional column tests conducted with GAC seem to suggest that under conditions more representative for water treatment applications (filtration of the $\mathrm{nC}_{60}$ dispersion through a $\mathrm{GAC}$ fixed-bed column), the retention of $\mathrm{nC}_{60}$ by $\mathrm{GAC}$ can be considerable ( $\left.90 \%\right)$. However, results of isothermal sorption experiments with nanoparticles should be handled with care, as these measurements are based on the thermodynamic equilibrium concept and do not include filtration effects during kinetic deposition. 


\subsection{Outlook}

This dissertation addresses coagulation, flocculation, sedimentation (CFS), activated carbon (AC) and low pressure membrane processes as barriers for eNPs removal in drinking water treatment, more specifically $\mathrm{nC}_{60}$, silver and gold eNPs as model eNPs in the production of clean and safe drinking water.

The investigations were conducted with model eNPs. However, many more eNPs exist and potentially end up in water sources and challenge water treatment plants. These materials can have different physical/chemical properties than the eNPs investigated here. In this perspective it is preferable to identify general rules that govern separation processes as a function of the physical/chemical properties of eNPs (e.g. size, size distribution, chemical composition, surface properties), the material properties (e.g. membrane type, membrane pore size, coagulant type, activated carbon size and surface functional groups), the process and operational parameters (e.g., filtration flux, backwash frequency, coagulant dosage, AC contact time etc.) and the water composition (NOM content and its fractions, ionic strength of the solution, etc.). Extending the research framework adopted here to a wide set of eNPs, will provide an essential database for removal approaches. This database can be used to develop suitable removal methods of eNPs given a specific treatment process and water composition for instance using quantitative structure-property relationship methods.

In order to do this, certain aspects need more investigation:

- A complementary set of analytical methods that allow an extensive characterization of eNPs in terms of (i) the chemical composition of eNPs, (ii) their size and size distributions before and after the water treatment and (iii) their surface properties such as surface charge and hydrophobicity. The set of techniques should also be able to characterize the eNPs in complex media such as natural water backgrounds. The high resolution mass spectrometry used in this work can be coupled with asymmetrical flow field-flow fractionation to identify and quantify the different size fraction of $\mathrm{C}_{60}$ agglomerates while atomic force microscopy can be used for the characterization of the surface properties; 


\section{Chapter 7}

- Extensive characterization of the water background in which eNPs are dispersed is also essential to evaluate the colloidal stability of the eNPs in the water. In addition, knowledge of the water composition, its fraction and their character (e.g.: hydrophobic or hydrophilic humic acids and biopolymers) and would also be beneficial in unveiling the interaction mechanism between the NOM fractions and eNPs that lead to synergistic membrane fouling effects or predicting competitive adsorption mechanism between eNPs and natural organic compounds in AC treatments. Liquid chromatography coupled with organic carbon detector, fluorescence excitation-emission matrix or XAD resin fractionation are promising techniques for NOM characterization;

- Complete characterization of engineered surfaces used for eNPs separation (i.e.: membrane surface, activated carbon surface and flocs formed during coagulation flocculation processes) is also essential in determining the interactions of these surface with eNPs. X-ray photoelectron spectroscopy, atomic force microscopy, contact angle and zeta-potential measurements can be applied to characterize the hydrophobicity and charge of engineered separation surfaces.

This dissertation addresses the efficiencies of coagulation, flocculation, sedimentation, activated carbon and low pressure membrane processes in removing eNPs, but considers these processes separately. However, in the perspective of a multi barrier approach, the production of drinking water must not be seen as a train of stand-alone process units, but as an integrated system that can synergistically accomplish the complete removal of a complex mixture of pollutants, among which eNPs. The integration of coagulation, flocculation, sedimentation and low pressure membrane filtration can be a complementary combination of treatments to purify water: membrane filtration can insure the high removal efficiency of $\mathrm{nC}_{60}$ under a wide spectrum of water compositions; additionally coagulation, flocculation, sedimentation in front of the membrane can mitigate the degree of fouling during filtration, removing a substantial part of eNPs and other foulants such as NOM. This is also the case for in-line coagulation (i.e. coagulation and flocculation of colloids without the separation from water by the sedimentation step), which can destabilize the eNPs by charge neutralization, inducing eNPs agglomeration and ultimately forming a more porous 


\section{Removal of Engineered Nanoparticles in Drinking Water Treatment Processes}

deposition layer that allows a better control and mitigation of membrane fouling. In the perspective of microfiltration pre-treatment also the use of PAC prior to filtration is expected to remove part of the NOM and eventually minimize the synergistic effect on membrane fouling between $\mathrm{nC}_{60}$ and $\mathrm{NOM}$ and its fractions as observed in Chapter 3 of this dissertation. 


\section{ACKNOWLEDGEMENTS}

I am very grateful to my promotor Kitty Nijmeijer for accepting this role in the last years. For the unlimited trust and for being always so optimistic on my promotion. For all the encouragements received and for the attention put on this research. She certainly improved the quality of this thesis and brought out the best in my work.

To my co-promoter and mentor Emile Cornelissen goes all my sincere and deep gratitude for being always my first point of reference and for providing guidance in my development as scientist. His great enthusiasm and knowledge have been the foundation of this achievement. I am very grateful for all the freedom and support that my research intentions have received. I could not have been more lucky to have him helping me through this process. And of course, for sending me to China against my will, thanks will never be enough.

To prof. Hilgenkamp, prof. Mugele, prof. Lammertink, prof. Rietveld and prof. Verliefde for accepting to be part of this promotion committee. I feel very much honored to be able to defend this thesis in front of them.

I extend my gratitude to the NanoNextNL partners for their scientific contributions, for their indispensable technological support and for the help aligning this research to a real context. I am very much obliged to Antoine Kemperman, Krzysztof Trzaskus, Ron Jong, Jens Potreck, Joris de Groot and Jeroen Ploegmakers for these years working together.

At KWR Watercycle Research Institute, I had the unique opportunity to work closely with recognizable experts in the water technology field. I would especially like to thank all the colleagues who contribute to the work and shared some time of the last years with me. In primis Erwin Beerendonk, Jan Hoffman and Jan Post, for letting me join the DWB team and for believing in my capacities. Hendrik Beverloo, Danny Harmsen and Wolter Siegers for the unevaluable help in the labs and pilot facility. Bas Hofs for let me realize that nanoparticles in water are quite good friends of colloids. Hans Huiting for his precious short classes on membrane applications. Sidney Meijering and Harry van Wegen not only for building an outstanding installation, but also for their infinite help in developing the set-up and fixing my frequent damages. Erik Emke for introducing me to the analytical quantification of nanoparticles in water and to all the analysts and technicians of CWG team for their patience having me around in the labs. Ana Causanilles, Josep Sanchiz and Vicky 
Osorio Torrens for the priceless tutoring dealing with mass spectrography analysis. Corentin Tropee, Gerry Williams and Guillaume Moser for their experimental contributions and for let me supervise them during their internships at KWR. Peter van Thienen for let me understand that I wanted to do $\mathrm{PhD}$ and for all the encouragements in starting this adventure. Ilse Pieterse-Quirijns for showing me the right door at the very right moment and Sabrina Botton for convincing me that I could knock that door. I would like to acknowledge all the international side of KWR and lunch/coffee' break mate for these years spent together: Ana, André, Andreas, Bea, Helena, Irene, Jorge, Josep, Juan Carlos, Kerusha, Sara, Vicky and Yuki.

As $\mathrm{PhD}$ candidate, I was also part of the Membrane Science and Technology group of the University of Twente, which was for me a great opportunity of development. Presenting the experimental results to the group was always a great scientific challenge and occasion of personal enrichment. The Monday morning lectures of the $\mathrm{PhD}$ fellows were always source of inspiration. Thanks to all of you for accepting me in the group in spite the distance. A special thanks to Herman Teunis for his art taking SEM, Audrey Haarnack for the kind assistance through these years and Mary Tijdink for guiding me in the last bureaucratic steps.

In the last year, I have been working on this thesis next to my new position as scientist at PWNT. I feel to spend some words of sincere gratitude for the patience and the support to Gilbert Galjaard and Bram Martijn, Nanny Gressie, Debbie Middendorp, Jumeng Zheng and Emmanuelle Prest.

A special personal thanks to my little Dutch community that came along in these years below the sea level. Thanks to all my friends, whenever staying around, escaping somewhere or coming back now and then! Completely random order thanks to Duarte, Niels, Susanne, Ioanna, Carol, Kadim, Fred, Anouk, André, Elisa, Maria, Gabriele, Francesca, Benjamin and Patrizia. To my paranymphs Sarah and Stella, thanks for all the good life, for accepting to stand next to me while defending and for just being my friends.

To my parents and my sister. Ai miei genitori e mia sorella, per avermi sostenuto incondizionatamente nonostante "su continenti", le mie assenze occasionali o i miei silenzi. Per avermi fatto sentire a casa ogni volta in cui ho avuto bisogno di loro, in qualunque posto mi trovassi. 
Certainly, to Laura who never left me without advises, support and love. Sei stata al mio fianco anche nei passaggi più difficili di questo percorso, sempre aiutandomi a ridimensionare tutto con la tua leggerezza da ballerina. Grazie per non aver mai smesso di credere in me.

Amsterdam, 31 January 2017 

Cominciavo a intuire che la storia narrata era la storia delle donne e degli uomini che hanno vissuto prima di noi nell'isola dei danzatori, madri e padri forse a noi simili per dolcezza e sorrisi o per la follia che non sappiamo dove nasca. Passavamo sulla terra leggeri come acqua, come acqua che scorre.

I began to realize that the story told was the story of the men and women who have lived before us in the island of the dancers, mothers and fathers, perhaps similar to us for kindness and smiles or for the madness that we do not know from where is coming from. We passed through earth lightly as water, as water flowing.

Passavamo sulla terra leggeri

Sergio Atzeni 